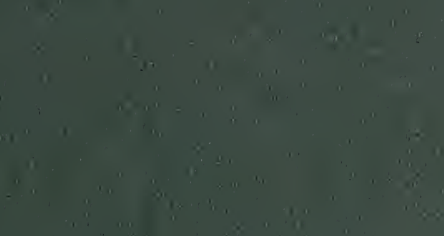








I 


\section{PLEIOCENE FOSSILS OF SOUTH-CAROLINA:}

\section{WILLIAM H, DALL \\ SECTIONAL LIBRARY \\ DIVISION OF MOLLUSKS}

CONTAINING DESCRIPTIONS AND FIGURES OF THE

Division of Malli: $\mathrm{E}^{4}: \mathrm{s}$

Sectional Librury

\section{POLYPARIA, ECHINODERMATA AND MOLLUSCA.}

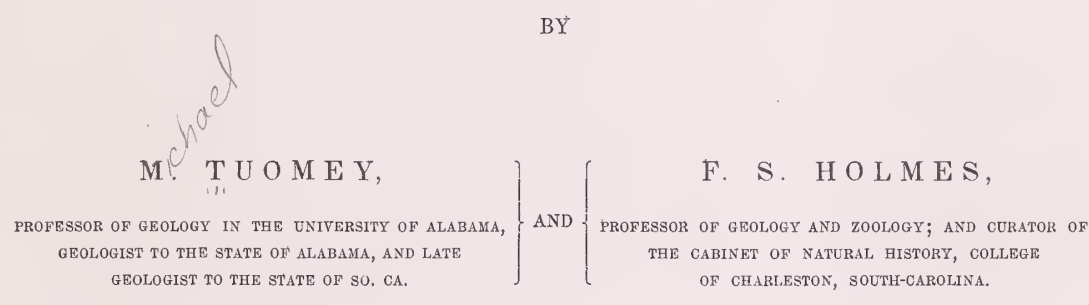

CHARLESTON, S. C.

RUSSELL \& J0NES, 251 KING-STREET. 
CHARI, EST ON:

JAMES \& WILLIAMS, PRINTERS, 16 State Street.

C. G. PLATEN, DRAUGHTSMAN. 


\section{T R I B U.T E.}

The sad intelligence of the death of our esteemed friend and associate, Professor M. Tuomey, reached Charleston while the present volume was yet unfinished.

Only a few months had elapsed since he had parted from us in the full enjoyment of his usual vigorous health, and animated by the highest anticipations of the future; and he had just reached the field of his labors, when he was suddenly removed, by death, from that sphere of usefulness and distinction. He died at Tuscaloosa, Alabama, on the 30th of March, 1857.

At the time of his death he was Professor of Geology and Agricultural Chemistry in the University of Alabama, and Geological Surveyor of the State.

Our intimacy commenced in the year 1844. Soon after he entered upon his duties as Geologist of the State of South-Carolina, an office to which he had been recently appointed by Governor Hammond. The congeniality of our pursuits induced a friendship that continued not only without interruption, but with increasing warmth, until the day of his death.

Professor Tuomey was of Irish parentage, and was born in the eity of Cork, in September, 1805. Little is known to us of his early life and studies, except that he early imbibed from his parents an ardent admiration for the beautiful, in the productions both of nature and of art, and a strong predilection for the pleasing investigations of botanical science.

In his character was found a rare combination of admirable qualities. To the gentleness and simplicity of childhood, were united the courage and independence of manhood, and the principles and sentiments of the gentleman. His attainments in science and scholarship were not less conspicuous than his piety, always endeavoring, in his instructions, to lead the youthful mind "from nature up to nature's God."

A friend who enjoyed ample opportunity of observing his character, bears the following honorable testimony to his worth:

"His great amount of knowledge in various branches of scholastic learning, his remark- 
able attainments in the natural sciences, obtained by observation in extensive fields, which even the best books and schools could not substitute,--his excellent virtues and principles, were all, in a manner, kept concealed in silence, and only learned by long and intimate acquaintance, or by the occurrence of circumstances which necessarily brought these characteristics into action."

Honest, sincere, and disinterested, he took great delight in imparting his knowledge to others, and greatly rejoiced in the prosperity of his friends. He cherished a strong attachment for the State of South-Carolina, and often dwelt with great earnestness of manner, on the characteristics of her people; the great happiness he had enjoyed during his intercourse with them, and the determination he entertained to return at a future day with his family, and make this State his home.

Alas! this gratification has been denied him; death has prematurely snatched him from his family and friends, and he now sleeps in the bosom of that earth, whose mysterious history he delighted to study, and her treasures to develop for the benefit of his fellow-men.

F. S. H. 


\section{P R E F A C E.}

The final report of Professor Tuomey on the geological survey of South-Carolina was published in the year 1848; the Legislature had authorized its publication in 1846, so that it was nearly two years passing through the press. This delay was, at the time, supposed by some to arise from the neglect of the Surveyor in furnishing the fossils, which were to have been copied and engraved, as illustrations of the text; but this was not the cause; the fossils required for twenty plates had actually been prepared and arranged for the draughtsman, and several of the plates had been drawn and printed; but the artist engaged by the publisher to do the press work, ruined the first two plates, after obtaining from them about two hundred impressions only.

The committee in charge of the work then allowed the printing to proceed without the plates; and in exculpation of himself, the author appended the following postscript to the preface of the report:

"While the report was passing through the press, A. S. Johnson, Esq., the publisher, informed me that the committee on publication had decided that the plates containing figures of the fossils of the State, which were to have accompanied it were not essential, and they are, therefore, omitted."

At the meeting of the American Association for the Advancement of Science, held in Charleston, in May, 1850, the disappointment of geologists, occasioned by this omission, was the common topic of conversation; and at the urgent solicitation of a number of the members, among whom were Professors Agassiz and Bache, Dr. Gould and others, who had examined our collections, we concluded to attempt their publication, at our own risk and cost.

We have published the work, and it is now before you. Its artistic merits, we believe, will challenge the severest criticism; but as a scientific work, descriptive of the forms of the Pleiocene formation of South-Carolina, we only claim for it entire truthfulness in what we have described. The congratulatory letters received from such savans as Agassiz, d'Orbigney, Leidy, Dana and others, and the unsolicited expressions of approval by the public press, both at home and abroad, amply compensates us for our part of the labor. 
The drawings were all done on stone, at the College of Charleston, by Mr. C. G. Platen, an artist in this department, who has no superior in our country. The letter press is in part by Messrs. Harper \& Calvo and Messrs. James \& Williams, all native printers of the city of Charleston. As there was no press for printing the plates, in our city, we were compelled to have them done elsewhere.

The expense of preparing and publishing such a work was much beyond the calculation we had made at the commencement, and the liberality of the Legislature in subscribing for two hundred copies, alone saved us from heavy loss, and enabled us to complete it in the best style of art. It is a good specimen of what can be done by our artists at home.

Should the State, in her generous love of science, determine to continue her patronage, it is proposed to complete the publication of the Tertiary fossils, by describing and illustrating the interesting forms that have been discovered in the Post Pleiocene and Eocene formations. 


\section{ACKNOWLEDGMENTS.}

In acknowledging the obligations we are under to those who have so kindly assisted us, we perform a most pleasant duty.

To Professor McCrady, our colleague, we are indebted for valuable assistance in describing the Echinodermata of the Pleiocene; his initials, J. McC., will be found attached to his descriptions.

Our sincere thanks are due to Dr. Edmund Ravenel, one of the pioneers of Natural History in South Carolina, for a number of fine specimens discovered in the marl-beds at his residence, the Grove; and for the use of valuable books from his library.

It would be impossible to specify the numerous obligations we are under to our distinguisher colleague, Professor L. R. Gibbes; his unabated attention to the best interest of the work, and his liberality in devoting his time and talents to our aid, places us under profound obligations to him.

To the Rev. Professor James W. Miles, we are especially indebted for contributions to our classical descriptions, revisions, and equally valuable aid in the correction of proofs.

From Dr. R. Leaumont we acknowledge numerous favors, and much valuable information.

Our readers will observe that we have dedicated to the Hon. C. G. Memminger a new species of fossil pholas, P. Memmingeri. In doing so we have endeavored to show our appreciation of his love of science and learning, and grateful sense of the lively interest manifested by him for the success of this work.

We have also dedicated another fossil, a volute, to George A. Trenholm, Esq., by whose liberal aid alone we were enabled to undertake and complete this expensive publication.

Our thanks are also due; and we most heartily tender them, to the Hon. Mitchell King and the Hon. J. J. Middleton, who from the first, have evinced the deepest interest in our undertaking.

From the Hon. Alex. Hasell, Hon. Thomas M. Wagner, Dr. R. W. Gibbes, Edmund Ruffin and Edward McCrady, Esqrs., we recejved very important assistance, for which we feel extremely grateful.

In the prosecution of our investigations we were every where received and entertained with that true hospitality and kindness which Carolinians know so well how to dispense, and all seemed anxious to foster and sustain the effort to develop the natural history of this department in our State. 



\section{N T R O D U C T I O N.}

IN Maryland and Virginia numerous isolated beds of sands and clays are found overlying the Eocene marl. Mr. Conrad, the distinguished American palæontologist, determined after a careful examination of three hundred and forty-four species, that fourteen per cent. of the fossil shells therein were of living species, and therefore, according to Sir Charles Lyell's classification, these beds were referred to the Meiocene period of the Tertiary. Upon investigating similar beds in South-Carolina, we ascertained the number of recent species to be far greater than this; that the fossils common in the former were rare or even missing in the latter, and that the characteristic species of the two formations were distinct.

In the final report on the Geology of South-Carolina, made in 1846, these beds were referred to the Pleiocene period, a newer division of the Tertiary; since then eleven years have elapsed, during which time we have collected a number of fossils, and investigated to a great extent, the lithological as well as palæontological characters of this interesting formation, and now feel quite assured of the propriety of thus distinguishing them.

Two hundred and three species are figured and described in the present work, eightyfive, or about forty-two per cent. are known to be recent, and now living in the waters of the present period, and when the existing fauna of our sea-coast shall be carefully studied, the percentage will be greatly increased.

Of the forty-six species restricted to the Pleiocene of this State, many also are without doubt, still living upon the coast.

From careful investigations the following tabular synopsis is presented of the extinct and recent species found in the beds of New Jersey, Virginia, North and South Carolina:

$\begin{array}{lrrrrrl}\text { New Jersey, of } 170 \text { species, } 22 \text { are recent, } & =13 \text { per cent. } \\ \text { Virginia, " } & 160 & \text { " } & 29 & \text { " } & =18 & \text { " } \\ \text { North-Carolina, " } & 80 & \text { " } & 27 & \text { " } & =34 & =34 \\ \text { South-Carolina, " } & 203 & \text { " } & 85 & \text { " } & =42 & \text { " }\end{array}$


The species found in South-Carolina are distributed among the following classes:

Polyparia, - - $\quad-\quad 2$
Echinodermata, - $\quad-9$
Bryozoa, - - - $\quad$ - 9

\begin{tabular}{|c|c|c|c|}
\hline $\begin{array}{l}\text { Brachiopoda, } \\
\text { Lamellibran }\end{array}$ & & & \\
\hline Gasteropoda, & - & & \\
\hline
\end{tabular}

Table showing the geographical distribution of the same:

\begin{tabular}{|c|c|c|c|c|}
\hline & $\begin{array}{l}\text { Found in the Meio- } \\
\text { cene of Virginia, } \\
\text { and also in South } \\
\text { Carolina. }\end{array}$ & $\begin{array}{l}\text { Found in the Plei- } \\
\text { ocene of } \mathrm{N} \text { and } \mathrm{S} \text {. } \\
\text { Carolina. }\end{array}$ & $\begin{array}{l}\text { Found only in the } \\
\text { Pleiocene of Sonth- } \\
\text { Carolina. }\end{array}$ & $\begin{array}{l}\text { Known to be in } \\
\text { existence. }\end{array}$ \\
\hline \multirow[t]{2}{*}{$\begin{array}{l}\text { Polyparia, } \\
\text { Echinodermata, } \\
\text { Bryozoa, } \\
\text { Brachiopoda, } \\
\text { Lamellibranchiata, } \\
\text { Gasteropoda, . }\end{array}$} & $\begin{array}{r}2 \\
3 \\
2 \\
34 \\
23\end{array}$ & $\begin{array}{l}3 \\
5\end{array}$ & $\begin{array}{r}9 \\
5 \\
16 \\
16\end{array}$ & $\begin{array}{r}1 \\
53 \\
31\end{array}$ \\
\hline & 64 & 8 & 46 & 85 \\
\hline
\end{tabular}

The sixty-four species found in the Meiocene of Virginia are rare in the Pleiocene of South-Carolina; of some, only a single individual specimen or valve has yet been discovered; for instance, Chama corticosa, and Pecten septemnarius.

Groups of fossils from Maryland, New Jersey, Virginia, North and South Carolina, could be readily distinguished from each other even by persons not familiar with their specific characteristics; for example, Fusus parilis, F. rusticus, Corbula idonea, Panopea Americana, and Mactra ponderosa, would represent the Meiocene of Maryland; Cardium Virginianum, Pecten decemarius, P. Virginianus, Colus exilis, Venus capax, Pectunculus tumulus, and Anomia Ruffinit, the Meiocene of Virginia, whilst the Pleiocene of North and South Carolina would be distinguished by such forms as Cyprea Caroliniana, Conus adversarius, Mitra Caroliniana, Pecten Mortonl, Arca lienosa, A. hians, Galeodia Hodgit, Janira hemicyclica, Fasciolaria distans, Busycon Conradit.

There is also considerable difference in the tithological and minerological character of these formations, the one indurated more or less, and the other comparatively soft and friable. According to Mr. Ruffin, the Meiocene of Virginia does not average forty per cent. of carbonate of lime, whilst in the Pleiocene beds we find about seventy per cent.

The deposits of the Pleiocene period in South-Carolina are confined to mere patches, occupying the depressions in the Eocene and Cretaceous rocks which have been protected from denudation by the more elevated portions of the beds on which they repose. Rising gently from the Atlantic coast, they reach their greatest elevation in Darlington District, and exposures occur in Sumter, Marion, Horry, Colleton and Charleston Districts. 
The following is a list of the most important localities in the State :

Horry District.-Mouth of Little River, near the North Carolina boundary line; Timber landing, on Little River; Mr. Bessant's; Mr. Vaught's; Grissett's landing, Waccamaw River, above Conwayborough; Porter's landing; Harper's lánding; Waller's ; Nixon's, on Tilly's lake; Royal's ferry; Harris' landing; Harrelson's, near Galovant's ferry, Little Pee Dee; Henry Davis, Gile's Bluff; Godfrey's ferry, Pee Dee.

Marion District.-Witherspoon's bluff; Mr. Fountain's; Mr. Zimmerman's.

Darlington District._-Village of Darlington, numerous localities around; —_ Dargan; Col. Ervin's; Rev. Mr. Campbell; Swift Creek; Dubose's ferry; J. M. Timmons; Elmore's; Dr. Muldrow.

St. John's Berlieley.-T. Porcher, Esq., near Eutaw.

Cooper River.-Dean Hall, the residence of E. N. Ball, Esq.; The Grove, residence of Dr. Edmund Ravenel.

Goose Creek:-The plantation of the late Geo. Henry Smith, Esq.; the plantation of S. N. Steavens, Esq.

Edisto River.-The Bluff, near Givham's ferry. This is the most southern exposure of the Pleiocene marl known on the Atlantic slope of the United States. 



\section{I $\mathrm{N} \quad \mathrm{D} \quad \mathrm{E} \quad \mathrm{X}$.}

A

Acephala

Acus ('arolinensis

" dislocatum

" unilineata

Amphidesma æqnata

$$
\text { .. carinata }
$$$$
\text { " equalis }
$$

Amplidetus amphliforus

Anomia ephippium

Anomidæ

A pollon caudata

Arcacidæ

Area cælata .

“ centenaria

" equicostata

" hians
Agassizia porifera .

PAGE
18
137
125
137
5
95
93
93
94
6
7
18
18
142
31
36
37
44
34

B.

Bracliopoda

Brissopsis porifera

Brissus spatiosus

Bryozoa

Buccinida

Buccinis ampullaceis . . . 148

Huccinum ampullacies, etc . . 145

$\begin{array}{lllll}\text { " anpullaceum } & & & & 146 \\ \text { " } & & & \\ \text { " multirugatum } & & . & & 136 \\ & & & . & 133\end{array}$

"nov, eboracensis . . 135

Calyptræidæe

. $\quad 107$

costata . . 107

Cancellaria depressa . • . 143

" reticulata. " 143

" venusta . . 144

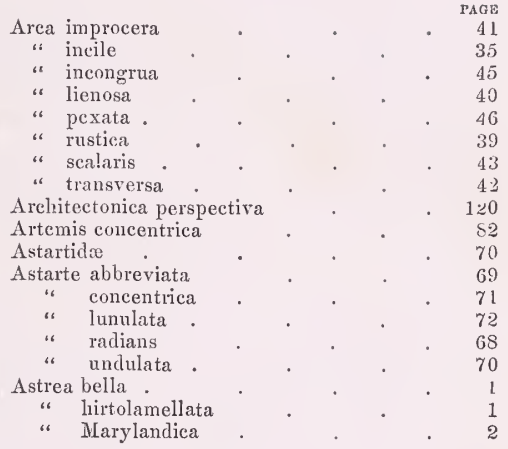

Buccinum oliviforme . . 135

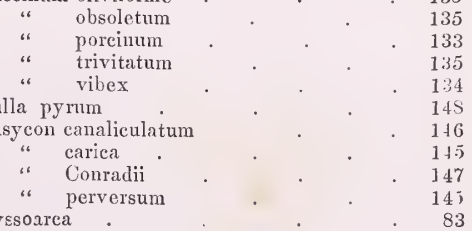

C.

Cardiadx . . . $\quad 63$

Carditidx . . 65

Cardita abbreviata . . . $\quad 69$

"arata. . . 6. . 65

" carinata 67

" granulata $\quad . \quad 6 \quad$. $\quad 66$ 


\section{C._continued.}

Cardita perplana

tridentata

Carditamera arata

$$
\text { " carinata }
$$

Cardium muricatum

" sublineatum

" magnum .

" maculatum

" ventricosum

Cassidulus Carolinensis

" pyrum.

Cellepora formosa.

" depressa

" informata

“ radiata

“ tessellata

Cerostoma umbrifer

Chamacidx

Chama arcinclla

" collgregata .

“ corticosa

Columbella avara

Colus cinereus

" exilis

" quadricostatus

Conchifera

Conidæ

Conus adversarius

"diluvianus

Corbulidæ
PATE

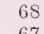

67

65

67

64

64

63

63

63

147

148

138

12

14

1.

13

13

141

22

22

22

$1: 9$

150

149

15

131

$13 \mathrm{t}$

132

D.

Dentaliadæ

Dentalium attenuatum . . . 105

“ pleiocenum . . . . . 106

Dimyaria

Dispotæa costata

Echinodermata

F.

Dispotæa dumosa.

$$
\text { " multilineata }
$$

Dolium galea

Donax variabilis.

Encope macrophora

F.

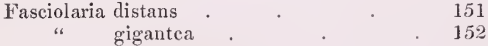

" mutabilis . . . 128

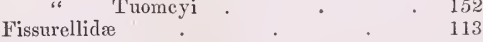

Fissurella redimicula . $\quad . \quad 113$

Fulgur canaliculatum .

Fulgur carica $\quad . \quad$. 145

" pyruloides.

" . . . . 148

Fusus cinercus . . 150

" exilis . . . 150

"quadricostatus . 149

G.

Galeodia IIodgii _ . . 138

Gasteropoda . . . 105

Gnathodon Grayii 99

"minor 99

H.

Heteropora tortilis

16

Hipponix Bullii 
I.

Infundibulum centralis .

J.

L.

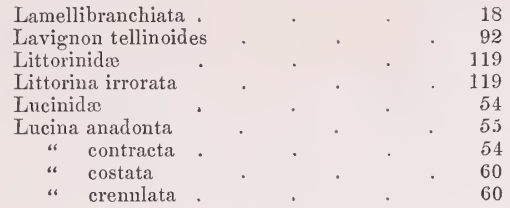

Lucina cribraria $\quad$. 58

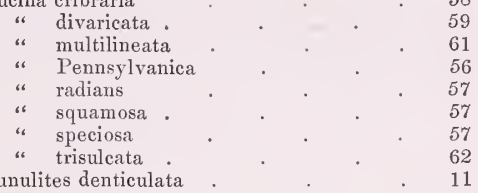

M.

Mactra congesta . $\quad$. $\quad 98$

" lateralis

“ oblongata. . .

“ similis

“ tellinoides. . 92

'Marginella limatula . • . . 130

Mellita Caroliniana . 3

Membranipora lacinia . . . 14

$\begin{array}{lll}\text { Mitra Carolinensis . } & \text {. } & 129\end{array}$

Nollusca . . . . 11

Nassa lunata . . . . 136

" obsoleta . . . 135

" trivittata . . . 135

“ vibex . . . 134

Natica canrena . . . . 115

" Caroliniana . . 116

" duplicata . . . 114

" heros . . . 114

O.

Obeliscus arenosa . . . . $\quad 126$

Oliva literata $\quad . \quad+140$

Orbicula lugubris . $\quad . \quad 17$

Orthoconchæ

N.
" multilineata. . Is

Monodonta Kiawahensis . . 116

Murex umbrifer . . 14L

" canaliculatus . . 146

" carica. . . . 145

Muricidæ 141

Mya reflexa . . . . 100

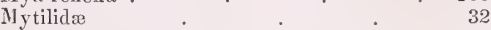

Mytilus incrassatus .

" inflatus. . . 33

Naticidæ $\quad$. $\quad$. $\quad$. 114

Nerita canrena . . . . 115

Nucula acuta. $\quad . \quad 53$

“ limatula . . . 52

“ obliqua -

“ proxima. . . 53

Nuculidæ . .53

Ostracidæ . $\quad . \quad$. 20

Ustrea Raveneliana $\quad . \quad 21$

" Virginiana . . . 20

“Virginica. . 20

P.

Pandora trilineata.

$\begin{array}{lr}\text { Panopea reflexa. } & 76 \\ \text { Pecten } & 100\end{array}$

Pecten comparilis '

“ eboreus. . . 28

“ hemicyclicus . . . 25

“ Holbrookii . . . 28

“ Mortoni . 27

“ Peedeensis . . 30

Peptenarius
Pectunculus aratus. $\quad . \quad 50$

“ lentiformis . . 48

“ lævis. . . 50

“ passus . . . 48

“ pulvinatus . . . 48

" quinquerugatus . . 49

“ subovatus . 47

“ transversus . . 51

Pericosmus spatiosus $\quad . \quad 6$

Petaloconchus seulpturatus . . 123 


\section{P.-continued.}

Petricola fornicata ,

" ploladiformis -

Pholadomya abrupta . . . 101

Pholas costata . . 10 .

" Nemmingeri . . 10 !

" oblongata . . . 103

Pisidium

Placunanomia plicato -

Plagionotus Holmesii . . . . . 9

“ Ravenelianus . 10

Plicatula marginata . . . . 24

Porcellana limatula $\quad . \quad 130$

Radiaria

Ranella caudata

Sealaria elathrus . . . 124

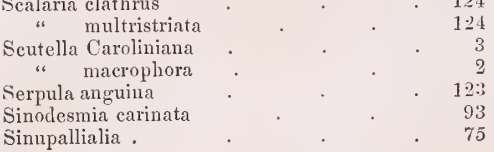

Porcellana oliviformis .

Psammechinus exoletus

Psammocola pliocena $\quad . \quad \cdot \quad . \quad 91$

Psammobia lusoria . . . 89

Purpura tridentata.

Pyramidellida $\quad . \quad$. 126

Pyranidella arenosa $\quad . \quad 126$

Pyrula carica 145

" canaliculata . . 140

" " perversa

" reticulata . . 149

" spirata . . . . 148

R.

Reptocelleporaria informata similis . 16

S.

Solarium perspectivum . . . 120

Solecurtus caribous. . . 99

Solen curvus _. 101

" ensis . . . . . 101

Spondylus . . . . $\quad 24$.

Strephona literata . 140

Sycotyphus reticulata $\quad$. 149

T.

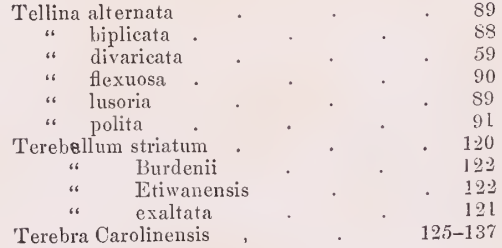

Terebra dislocatum . . $\quad 12.5$

“ uniliniata . . . 137

$\begin{array}{lll}\text { Trochita centralis . } & 0 & 109\end{array}$

Trochus armillatus . . . 118

" gemma . . $11 \mathrm{~s}$

“ perspectirus . . . 120

philantropus .

Turbinidx ? 116

Turbo irrorata . . . 119

Turris lnnatum . 132

'Turritella exaltata . $\quad . \quad 121$

V.

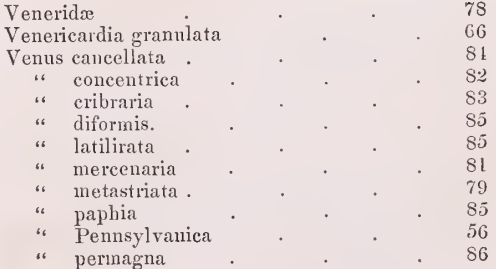




\title{
PLEIOCENE FOSSILS.
}

\author{
P O L Y P A R I A.
}

\author{
ASTREA.-LAM. \\ ASTR $Æ A$ BELLA.-CON.
}

Plate I. Fig. 1.

\begin{abstract}
Astræa bella, Con., Journal Ac. Nat. Sci., Vol. VIII., p. 189. 1842.
Astræa hirtolamellata, Michelin,-? Icon. Zooph., p. 162, pl. 44, fig. 5. 1845.

Astræa hirtolamellata, Lonsdaze, Quar. Jour. Geo. Soc., London, Vol. I., p. 499.
\end{abstract}

A. stellis polygonalibus, inoequalibus, profundis, lamellosis; lamellis numerosis, majoribus minoribusque alternis, denticulatis, hirtis, marginibus irregulariter plicatis.

Description. Stars polygonal, inequilateral, deep, lamellar; lamellæ numerous, alternately larger and smaller, denticulated and rough on the edges, on the sides prominently papillated; partitions between the stars thin and plaited by the alternate position of the lamellæ of the adjacent stars.

This coral, which is generally found incrusting other bodies, often assumes a globular shape. It is readily distinguished by the denticulated lamellæ, the great depth and well defined angles of the cells, and the thinness of the partitions.

Mr. Lonsdale refers this fossil without doubt to A mirtolameldata, Michelin. It is scarcely possible, however, that in the upper Tertiary beds of the United States there should be found a fossil common to them and the Eocenc of Grignon.

Plate I., Fig. 1. Coral nat. size, on a fragment of Pecten.

"1a. Star Magnified.

Locality. Darlington District.

Museum, College of Charleston, S. C. 


\title{
ASTR ÆA MARYLANDICA.-CoN.
}

Plate I., Fig. 2.

Astræa Marylandica, Con., Jour. Ac. Nat. Sci., Vol. VIII., p. 189.

A. incrustans, stellis polygonalibus, inequalibus; lamellis 12, minimis, rugosis.

Description. Incrusting; stars polygonal, irregular; lamellæ about 12 ; small, rough.

This species is chiefly distinguished from the preceding by the smaller number of the lamellæ, which are also less denticulated. The axes of the stars are in general more solid.

The genus Astræa is first found in the cretaceous system, continues upwards, and has its maximum developement in seas of hot climates of the actual period.

Plate I., Fig. 2. Coral nat. size.

"2a. Star entarged.

Locality. Darlington District, S. C.

Museum, College of Charleston.

\author{
R A D I A R I A . - LAM. \\ E CHINOD E R M A A.-CUV.
}

ENCOPE-AGASS.

ENCOPE MACROPHORA.-R.AVENEL.

Prate I., Fia. 3.

Scutella Macrophora, Ravenel, Jour. Ac. Nat. Sci., Vol. VII., p. 334.

Encope Macrophora, Ravenel, Catalogue of Echinidie Recent and fossil of So. Ca., 1848, p. 2.

E. disco subovato, postice truncato, margine incrassata; sinubus ambulacratibus latis, apertis; lunula postica elliptica, margine superne incrassata, magna; petalis posticis ovatis. 
Description. Disk subovate, truneated posteriorly, margin thiekened, ambulaeral sinuses wide, open; posterior lunule large, margin thiekened on the upper side; posterior petals narrow, elongated, incurved; anterior petals ovate.

Drmensions. Lon. 3 in., lat. $2 \frac{3}{4}$ in., alti. $\frac{3}{4}$ in.

This fossil resembles very closely a reeent speeimen in our possession from California, whieh is very near if not identical with E. Grandis, Agass.; a species supposed to be from the Antilles. In our fossil, however, the posterior edge is not emarginated, nor are the open lunules so deep; besides, the posterior lunule is wider anteriorly, and perforates the disk obliquely. This, it is believed, is the first instance in which the genus Eneope is undoubtedly known to oeeur as a fossil.

Plate I., Fig. 3. Upper surface nat. size.

"37. Lower surface.

" 3a. Profile.

Locality. Grove, Cooper River, S. C.

Museum, College of Charleston.

\author{
MELLITA.-KLEIN. \\ MELLITA CAROLINIANA.-RATENEL.
}

Plate I. Fig. 4.

Scutella Caroliniana, Ravenel, Jour. Ac. Nat. Sci., Vol. VIII. p. 333.

Mellita Caroliniana, Ravenel, Catalogue of Echinidæ Recent and Fossil of Sonth Carolina, 1848, p. 4.

M. disco suborbiculari, lunulis sex; lunulis ambulacralibus minimis, ovatis; lumula postica, elongata; petalis ovatis subclausis.

Description. Disk suborbieular, lunules six; ambulaeral lunules small, ovate; posterior lunule long, narrow, petals ovate, nearly elosed. Resembles M. Hexaphors, Lin., in general appearanee, but is easily distinguished from it by its having the disk more nearly orbieular, and more regularly convex on the upper surface. The ambulaeral lunules are also smaller in M. Caroliniana, besides having a slight depression extending to the eireumferenee from each of the ambulaeral lunules. The posterior lunule is nearly twiee the length of the 
others. The ambulacral furrows on the lower surface are less branched than in M. HEXAPHora. These characters likewise separate this fossil from M. smilrs, Agass. This is the lowest formation in which the genus Mellita has as yet been found.

The dimensions of an imperfect specimen, kindly lent us by Dr. Edmund Ravenel, of the Grove Plantation, Cooper River, are, Lon. $5 \frac{3}{4}$ in., Lat. $5 \frac{1}{4}$, Alt. $\frac{1}{2}$. The original of our drawing measures, Lon. $2 \frac{1}{4}$, Lat. 2, Alt. $\frac{1}{4}$.

Plate I., Fio. 4. Upper surface.

" 4b. Lower surface.

" 4a. Profile.

Locality.-Cooper River, Goosc Creek and Wadmalaw River.

Museum, College of Charleston.

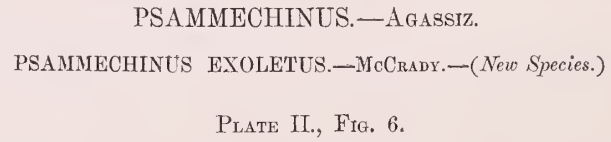

Psammechinus tuberculis ambulacralibus parvis, numerosis, frequentibusque.

Description. This small relic is hardly more than an indication of the existence of a new species. Fig. 6 is an enlarged view of the fragment, which is the upper end of one of the ambulacra and a somewhat injured piece of the inter-ambulacrum of its left side. The arrangcment of the pores in broken rows of three pairs each betrays one of those generic types allied to the true Echinus, and the two regular rows of large tubercles in the ambulacrum and the single row of still larger knops on the inter-ambulacrum, with the clear space between this row and its left edge, seem to assign it to the sub-genus Psammechinus of Agassiz, which is quite removed from the ordinary Echinus by the prominent scales on its buccal membrane. A species of this genus is now living on our coast, still undescribed, from which this fossil appears to differ in having the tubercles of its ambulacral series relatively smaller, more numerous and crowded.

PLate II., Fro. 6, is a view of the fragment enlarged to about nwice the natural size, to show the arrangement of the pores.

Locality. Smith's, Goose Creek, S. C. 


\author{
AGASSIZIA.-VAL. \\ AGASSIZLA PORIFERA.-MCCRADY. \\ Plate I., Fig. 5, and Plate II., Fig. 4.
}

Brissopsis porifera, Ravenel, Catalogue of Echinidæ Rec. and Foss. of So. Ca., p. 4, et fig. Charleston. (1848.)

Species magna, lata, alta, paene globosa, tamen postice truncata; intcr-ambulacris summis gibbosis; apice sexuali mediano; ambulacris paribus posterioribus longis, et extremitates animalis peripheriem versus leviter curvantibus; ambulacris anterioribus prope rectis, et omnibus non profunde impressis; poris ambulacribus plusve minusve rotundatis et semiambulacro obliterato totam ejus longitudinem non facili visu; impressione seu faciola laterali impressionis peripetalis angulum infimum incurrente; tuberculis maximis anteriorem testam densis. Infra, sterno lato; ambulacris posterioribus angustis, et tcstce periphericm versus arcuatis et posterioris regionis tuberculis maximis longum spatium densis.

Description. This large species exceeds the A. excavata ( Fal.) in height, but it is not conical like Brissopsis rimulata (Rav.) of the Eocene, which is also an Agassizia. It is more nearly spherical than either of those two species, having, however, a truncated appearance posteriorly from the great relative size of the Anal Facet. The upper ends of the inter-ambulacra are quite bulging. The sexual centre nearly median. The hinder paired ambulacra long and slightly bent outwards at their peripheral ends. The anterior paired ambulacra are nearly straight and have their obliterated half rows of pores scarcely perceptible for their whole length. The ambulacral pores are more or less circular in outline. The side-belt joins the outer star-belt at its lowest angle or elbow, and the foreshell is thickly strewn with the greater sized knops. On the nether surface, the breastplate is broad, and flanked by very narrow ambulacra, which are also somewhat bowed outwardly towards the outline of the shell, and are covered to an unusual extent posteriorly with large tubercles.

The specimen from which this description and figure are taken, is the only one yet brought to light, and was found by Dr. Ed. Ravenel, at his plantation, the Grove, Cooper River, in a bed of Pleiocine Marl. In his catalogue it is registered as a Brissopsis-the want of specimens and diagnoses of the two genera, at that time, precluding the possibility of his accurately determining its generic position. He generously placed it in my hands for description. It is, beyond doubt, an Agassizia, as is shown by the arrangement of its 
belts and the obliteration of the anterior half-ambulacrum in each member of the forward pair.

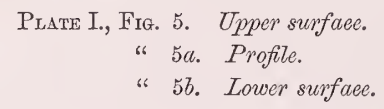

Plate II., FIG. 4. Enlarged view of part of an ambulaemum of the forward pair, showing the minute pores of the obsolete half-row.

4a. Magnified view of a large tuberele from beside the odd-ambulaerum.

Locality. The Grove, Cooper River, S. C.

(J. MaC.)

\section{AMPHIDETUS.-AGASSIZ. \\ AMPHIDETUS AMPLIFLORUS.-MCCrady.-(New species.)}

Plate II., Fig. 2.

Amphidetus maximus cordiformis modici longus, A. gothico longior; anteriorem testam latissimus; A. orthonoto aliquantulum similis sed antice angustior, et posteriora latera non compressus; gibbo anteriore vix prominente, et posteriore quoque humilissimo; fasciolae internae area latissima antice angustiore, et magnis tuberculis clavata; fasciolae subanalis non conservata, stella ambulacrali ampla, poris rotundatis, et intra fasciolam internam apertis poris paucis et ad apicem sexualem non pertingentibus; apice sexuali mediano; foraminibus genitalibus appropinquatis; interambulacrorum parium posteriorum jugis descendentibus remotis; facie anali non conservata, verum probabile est, quam A. orthonoti angustiore, plus rotundata et plus verticali.

Description. A large species, heart-shaped and at first sight similar to A. orthonotus, (Plate II., Fig. 1, $1 a, 1 b, 1 c$,) but differing in being not quite so broad anteriorly and narrowing less suddenly towards the Anal Facet; not very long, but longer than A. Gотнісus, next to be described. The anterior hump is rounded off, and much less prominent than in A. овтнолотUS; the posterior inter-ambulacral hump being almost nothing. The field of the inner star-belt is very broad, but narrowing towards the front, while the knops which stud it are of large size. The ambulacral star is ampler, covering more of the upper surface than in the Virginian species; its pores are more or less rounded and the rows of open pores within the belt do not reach the sexual centre, which is median; the genital openings are 
closely clustered; plate-ridges of the hinder pair of ambulacra widely separated; anal facet not preserved, but probably it was narrower, more rounded and more perpendicular in its descent than that of $\mathrm{A}$. овтномотUs. All that remains of the nether surface, that is a small portion of the second inter-ambulacrum of the right side, seems to indicate by its relative position a more depressed form than is characteristic of either of the other species described in this book.

This species has some general resemblance to the wood-cut of A. Viranianus, given by Prof. Forbes, in the London Journal of Geology, Vol. I., p. 425. But on closer comparison it will be seen that the two forms differ especially in the shapes of the inner star-belt-field, the convexity of the fore-shell, and the greater comparative breadth of the Carolinian fossil.

PLATE II., FIG. 2. Upper viow. In this figure, by an oversight of the artist, the field of the inner star-belt is broader anteriorly by about the width of the belt on each side, than it is in nature.

"2a. Profile.

Locality. The Grove, Cooper River, S. C.

\section{AMPHIDETUS GOTHICUS.-RAVENEL.}

Plate II., Fig. 3.

Amphidetus gothicus.-Ravenel, Cat. of Echinoderms Rec. and Foss, of S. C., p. 4. et fig. (1848.) Charleston.

Amphidetus maximus, altus, circumferentian circularis ; medio longitudine latissimus ; jugis descendentibus interambulacrorum parium posteriorum valde appropinquatis; poris ambulacralibus amplis, plusve minusve elongatis, paucibus et valde remotis in paribus collocatis; area fasciolae internae male conservata, sed probabiliter angustiore, tuberculis parvis clavata; $f a-$ sciolae subanalis lata; poris apertis intra fasciolam, numerosis, appropinquatis et ad apicem sexualem pertingentibus.

Description. This large species may at once be distinguished from the other fossil Amphideti of America, by its circular form and great height. Its greatest breadth, also, is about midway its length, the animal being proportionately narrow in front. The descending plate-ridges of the second pair of inter-ambulacra are nearer together than in the other species. The ambulacral pores few, large, and somewhat slit-shaped in the forward half-row 
of the anterior pair, and the hinder or inner half-row of the posterior pair of ambulacra, and less so in the remaining half-rows; the groove-yoked pairs of pores, also, are wider apart than in the other species, and the open pores within the star-belt-field more numerous and crowded, extending to the sexual centre.

This species was discovered by Dr. Edmund Ravenel, in the Pleiocine bed on his plantation, called the Grove, Cooper River, and distinguished by the foregoing name, it was registered in his Catalogue without description. It is here described from the original specimen, and is a large, beautiful and well-marked species, entirely distinct from any other heretofore described.

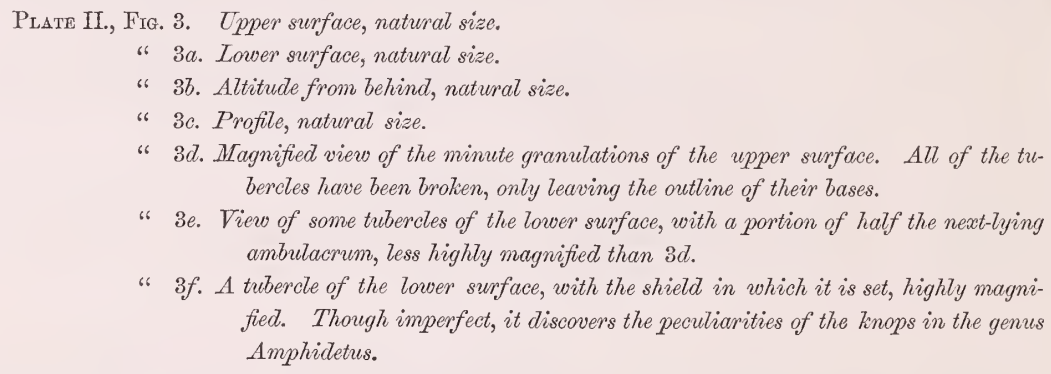
bercles have been broken, only leaving the outtine of their bases.

"3e. View of some tubercles of the lower surface, with a portion of half the next-lying ambulacrum, less highly magnified than $3 d$.

" $3 f$. A tubercle of the lower surface, with the shield in which it is set, highly magnified. Though imperfect, it discovers the peculiarities of the knops in the genus Amphidetus.

Localrty. The Grove, Cooper River, S. C.

\section{BRISSUS.-KLeIN.}

BRISSUS SPATIOSUS.-MCCradX.

Plate III., Fig. $1,1 a, 1 b, 1 c$.

Pericosmus spatiosus, Ravenel, Cat. Echin. Rec. and Foss. of So. Ca., p. 2. (1848.)

Brissus maximus, Brisso ventricoso Cubense valde similis, sed probabiliter humilior; et basem magis circularis; Ambulacro impari in fosso profundo et lato depresso; Ambulacris alteris in fossis, quam speciei Cubensis minus profundis, sitis; Infra-sterno lato-Undique Thberculis numerosis frequentibus, et parvis, clavatus.

A very large Briscus very similar to the B. ventricosus of Cuba, but probably of less height, and more circular in the outline of its base. The odd ambulacrum is set in a broad 
and deep groove, the others in shallowcr ones. Below, we find the breast-plate very broad and every where the shell appears to have becn studded with numerous, crowded knops, relativcly smaller in size than those of the Cuban species.

This description is taken from an imperfect cast, (an uppcr view of which is given, Plate III., fig. 1,) and several fragments, one of which, a breast-plate, is figured on the samc Plate, fig. 1a. The cast was found by Dr. Edmund Ravenel, and noticed by him in his Catalogue as Pericosmos spatiosus, with the remark that when more data should be obtained, it would probably be necessary to remove it from that genus. Having enjoyed, through the kindness of Dr. Ravenel and Prof. Agassiz, an opportunity of more accurately determining its generic characters, I remove it to the genus Brissus. It is intended also to give a monographic account of the remains of this and the two following species, in an appendix to appear at a later day.

Plate III., Fig. 1. Upper view of cast. There remain only partial impressions of two Ambulacra, the odd one, and the left limb of the first pair.

" 1a. A breast-plate, with part of the hinder ambulacrum of the left side.

“ 1b. Enlarged knops, with their characteristic pentagonal shield, from a fragment of the lower surface.

"1 1. Profile view of another knop of the same kind.

Locality. The Grove, Cooper River, S. C.

(J. McC.)

\title{
PLAGIONOTUS.-AGASSIZ.
}

\section{PLAGIONOTUS HOLMESII.-MoCrady.}

\author{
Plate Mi., Fig. 2, $2 a$.
}

Fragmenta quae Plagionotum P. pectorali valde similem indicant, et jugis descendentibus interambulacrorum paris posterioris, modice appropinquatis; fasciola peripetali non antice duplicata. Probabile est-quod, animalis forma valde ovalis, et lata fuit.

This species is indicated by numerous fragments in our Pleiocene. It approached most nearly to the species figured by Seba and copied by Lamark, who gave the name, Spatangus pectoralis. - (Brissus (Plagionotos) pectoralis. - Ag.) The plate-ridges of the second pair of interambulacra are somewhat closely approached and the outer star-belt is not 
doubled round the fore-shell. In form it was probably a broad oval, still shorter and more circular than the living species which it most resembles.

I take pleasure in inscribing this species to Prof. Holmes, to whose efforts we owe the discovery, not only of a large portion of these fragments, but of many other important remains from the Tertiary of South-Carolina.

PLATE III., FIG. 2. Lower part of the hinder half-row from the right ambulacrum of the forward pair, with forward half-row of the interambutacrum immediately behind. "2a. Breast-plate, nearly entire.

Locality. Smith's, Goose Creek.

Museum, College of Charleston, S. C.

PLAGIONOTUS RAVENELIANUS.-McCradY.

Plate III., Fig. $3,3 a$.

Fragmenta quae Plagionotum stellae ambulacralis membris paribus anterioribus longis arcuatisque, et posterioribus probabile est curtis; duorum fragmentorum assulis fascioliferis tuberculorum maximorum ordine deprivatis; jugis descendentibus interambulacrorum parium posteriorum valde remotis; fasciola peripetali anteriorem testam duplicata; sterno lato et aliquantum triangulari indicant. Probabile est-quod anteriora latissima, posteriora curta, angusta fuit, animalis forma.

I have given the above name to a portion of the fragments found in the Pleiocene, which differ from those attributed to P. HoLMEsI, in having the intervals between the plate ridges of the second pair of inter-ambulacra greater, the forward pair of ambulacra relatively longer and more bent backwards, and the hinder pair probably shorter; the sternal plate, fig. $3 a$, somewhat broader, shorter, more massive, and inclined to the triangular form. It is probable, also, that this species was broader across the fore-shell and narrower behind than P. HoLmesm, with perhaps a less relative distance between the anal facet and the sexual centre. Perhaps, also, the belt-bearing-plates were entirely deprived of the ordinary rows of large knops, for the whole circuit of the star-belt.

I have gladly availed myself of this opportunity to connect with one of the forms of this 
ancient fauna, the name of my valued friend, Dr. Edmund Ravenel, who has himself been the pioneer in the study of the lower animals at the South.

Plate III., Fig. 3. The part of this species corresponding to fig. 2 of P. Holmesii, but more perfect. It will be observed that the belt-bearing-plate is without any row of great knops. Another fragment of the same part of the left side, not here figured, discovers the same peculiarity.

“ 3a. Imperfect breastplate.

Locality. The Grove, Cooper River, S. C.

Museum, College of Charleston.

Of the Echinodermata thus described, not one is found in the Meiocene of Virginia; Aмpнidetus oвтномотиs (Plate II., fig. 1,) is from the Meiocene of James River, Virginia, and introduced for comparison. Encope Macropora has its living analogue in Encope grandis, (Agass.) and Melitta Caroliniana, in Meldita hexapora, (Linn.) A few genera of Echinodermata are found as far back as the Palæozoic period; from the Triassic upwards they increase in number, and have their maximum development in the present seas.

M OLLUSCA. - LINN.

BRYOZOA.—EHREN.

\section{LUNULITES.-LAM.}

LUNULITES DENTICULATA.-CoN.

Plate IV., Fig. 1 to 5.

Lunulites denticulata, Con., Am. Jour. Sci., Vol. XLI., p. 348. (1841.)

Lunulites denticulata, Lons., Quar. Jour. Geol. Soc., London, Vol. I., p. 503.

L. subconica, depressa; superficie interna, radiato-striata granulata vel punctata; cellulis oblongis, denticulatis, quincuncialibus; oribus orbiculatis, vel semi-orbiculatis; margine crenulata.

Description.-Subconical, depressed; interior surface radiate-striated, granulated or punctate; cells oblong, denticulate quincunx; mouths circular or semicircular, margin crenulated. 
This little coral, which is abundant in the sandy marls of the State, is identical with one found in the Post Pleiocene. It presents considerable variation in the form of the cells, which are, however, always more or less denticulated. From the Eocene species it is distinguished by the quincunx arrangement of the cells.

The genus Lunulites is first found in the Cretaceous rocks, and occurs abundantly in the seas of the actual period.

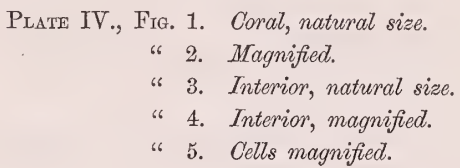

Locality. Marls of Darlington District, S. C.

Museum, College of Charleston, S. C.

\section{CELLEPORA.-FABRTCIUS. \\ CELLEPORA FORMOSA.-(New Species.)}

Plate IV., Fig. 6.

C. incrustans; cellulis ovatis, immersis, cequalibus, subquincuncialibus, vel sine ordine depositis, poris minimis cinctis; ore magno, rotundo.

Description. Incrusting; cells ovate, immersed, equal, somewhat quincunx or disposed irregularly, surrounded by a row of minute pores.

The distinguishing character of this beautiful species is the row of pores bounding the cells; on the sides of the cells, the pores are in double rows and seen obliquely, giving the cells the appearance of serial arrangement. Vertically the cells are separated by a single row of cells. This regularity is only observed when there has been no interference, for on other portions of the same specimen both cells and pores are irregular. The mouth is large and but slightly raised.

Plate IV., Fitg. 6. Coral magnified.

LocalitTY. Darlington District, S. C. 
CELLEPORA TESSELLATA.-(New Species.)

Plate IV., Fig. 7.

C. incrustans; cellulis minimis, subglobosis, depressis, quincuncialibus, interstitiis impressis ; ore minimo, constricto.

Description. Incrusting; cells small, somewhat globular, flattened, quincunx, with the boundaries between the cells defined by an impressed line; mouth small, contracted, slightly lipped; a small closed tubercle on the sides of the cells, which is sometimes conspicuously open.

The depressed globular form and great regularity of arrangement distinguishes this species.

Puate IV., Fig. 7. Cells magnified.

Locality. Giles's Bluff, Pee Dee River.

Museum, College of Charleston.

\section{CELLEPORA RADIATA.-(New Species.)}

Plate IV., Fig. 8.

C. incrustans; cellulis, ovato-oblongis ventricosis, subimbricatis, radiantibus, quincuncialibus; ore rotundo.

Description. Incrusting; cells oval-oblong ventricose, radiating, quincunx.

This fossil is found in irregular patches, consisting of a single layer of cells, on the surface of other fossils. Near the proximal edge of the mouth, which is not at all thickened, there is a small tubercle which is generally perforated, showing under the microscope a minute foramen.

Plate IV., Fig. 8. Cells magnified.

Locality. Smith's, Goose Creek. 


\section{CELLEPORA DEPRESSA.-(New Species.)}

Plate IV., Fig. 9.

C. incrustans; cellutis, depressis, ellipticis quincuncialibus; ore rotundo, prominulo, labiato, tuberculoso.

Description. Incrusting; cells depressed, elliptic, quincunx; mouth circular, slightly prominent, margined, tuberculose.

The cells are much flattened, somewhat indistinct, and separated by a depressed line. The mouth is small and depressed, with the lip slightly raised and thickened. On each side of the mouth there is a minute tubercle.

Prate IV., Frg. 9. Cells magnified.

Locality. Smith's, Goose Creek.

Museum, College of Charleston.

In the revision of BryozoA, D'Orbigny has restricted the genus Cellepora, Fab., to those species composed of a single layer of cells. He has also referred the species of Escharina and Escharoides, of M. Edwards, and Discopora, Lam., to this genus. Celleporaria, Luxrouroux, contains the branching species placed in CELLEPora, by Lamarck and others, and Reptocellepora has been instituted for those species composed of several cell-layers, heretofore included in CeLLLEPORA.

\section{MEMBRANIPORA.-BuANVILLE. \\ MEMBRANIPORA LACINIA.-(New Species.)}

Plate IV., Fig. 10.

II. incrustans, tenuis; cellulis contiguis, ovalibus vel sub-hexagonalibus, divergentibus quincuncialibus.

Description. Incrusting, thin, cells contiguous, oval or somewhat hexagonal, diverging quincunx. 
This beautiful fossil is found on the surface of submarine bodies, like circular spots of delicate, radiating lace-work. The walls of the cells are slightly raised at the distal extremity, so as to form small hoods, the only covering of the cells.

The genus Membranipora is found in the lower cretaceous beds, has its maximum in the upper portion of the samc formation, and is living in every sea.

Plate IV., Fig. 10. Cells magnified.

Locality. Smith's, Goose Creek.

Museum, College of Charleston.

\section{REPTOCELLEPORARIA.-D'ORB. \\ REPTOCELLEPORARIA INFORMATA.}

Plate TV., Fig. 11 and 12.

Cellepora informata, Lons., Quar. Jour. Geo. Soc., London, Vol. I., p. 505.

R. incrustans, subglobosa vel mamillosa, porosa; cellulis, inequalibus; ore rotundo vel ovato; margine elato, incrassato.

DesCRIPTION. Incrusting, irregular, subglobose, or with the surface mamillary, porous; cells unequal; mouth circular, raised, thickened.

This fossil occurs in irregular verrucose masses, composed of numerous layers of cells, and incrusting shells and other marine substances. The masses are often six inches in diameter. The densely porous surface and greater regularity of the cells, distinguishes this from the following specics.

PlATe IV, FIg. 11. Coral, natural size.

"12. Cells magnified.

Locality. Darlington District.

Museum, College of Charleston.

The fossil species of this genus are found as low as the upper cretaceous formation, and extend through the Tertiary. The living forms exist in the seas of warm, temperate, and cold climates. 


\section{REPTOCELLEPORARIA SIMILIS.}

Plate IV., Fig. 13 axd 14.

Cellepora similis, Lons., Quar. Jour. Geol. Soc., Lon., Vol. I., p. 509.

R. incrustans irregulariter; cellulis globosis, confusis ; ore magno, rotundo, terminali.

Description. Incrusting irregular, not porous; cells globular, confused; mouth large, eireular, terminal.

This species is easily distinguished from the preceding by the more even and less verrucose surface of the masses. The whole is covered by little elevations, which rarely become mammillary. The absence of pores, when viewed through a lens, separates it readily from R. informata.

Plate IV., Fia. 13. Fragment, natural size.

"14. Cells magnified.

Locality. Darlington Distriet, S. C. Found also at Petersburg, Virginia.

Museum, College of Charleston.

\section{HETEROPORA.-BLAIN. \\ HETEROPORA TORTILIS.-LoNs.}

Puate IV., Fig. 15 and 16.

Heteropora tortilis, Lons., Quar. Jour., Geol. Soc., London, Vol. I., p. 500.

II. ramosa-dichotoma; ramis rotundo, truncatis, brevibus; poris tubulosis inequalibus.

Description. Branching, dichotomous, branches short round, truneated; pores tubular round or somewhat angular, unequal.

The fragment figured is the only specimen yet found in South Carolina. Fig. 17 is a specimen from the Meiocene of Virginia, introduced to show the branching form of the 
fossil. The ends of the short branches are thickened and rounded. The arborescent form and surface covered with unequal, irregularly arranged and somewhat angular pores, as seen in Fig. 18, are sufficiently characteristic.

Plate IV., Fig. 15. Fragment of Coral.

" 16. The same magnified to show the pores, with a section of the lower part exposing the tubes.

" 17. Fragment from the Meiocene of Virginia, natural size, to show the branching.

Locality. Smith's, Goose Creek.

Museum, College of Charleston, S. C.

\section{BRACHIOPODA.-DUMERIL. ORBICULA.-CUT. ORBICULA LUGUBRIS.-CoN.}

Plate V., Fig. 1.

Orbicula lugubris, Con., Foss. Ter. For., p. 75, Plate XLIII., Fig. 2.

O. testa, ovato-orbiculata, depressa; valva superiore, lamellosa, vertice sub-marginali.

Description. Shell oblong-ovate, depressed; superior valve with the vertex towards the posterior margin.

This fossil is easily distinguished by the dark brown colour and corneous structure of the upper valve, the only part found. Behind the apex, the surface is marked by some obsolete radiating lines. The rest of the shell is smooth, or lamellar.

Plate V., Fig. 1. Fossil, natural size.

Locanity. Dr. Davis's, Pee Dee River.

Museum, College of Charleston, S. C. 
ORBICULA MULTILINEATA.-CoN.

Orbicula multilineata, Con., Foss. Ter. For., Plate LXXV., Fig. 3.

O. testa, orbiculata; valva superiore, radiatim tenuistriata, lamellosa, vertice sub-centrali.

Description. Shell, orbicular; superior valve, with fine radiating lines, apex sub-central.

This species is separated from the preceding by the radiating lines, and by having the apex nearly central. Even in young specimens of $O$. LUGUBRIs the apex is marginal, as represented in Plate V., Fig. 3. The Eocene is the lowest formation in which the genus ORBICULA Occurs.

Plate V., Fig. 2. Fossil, natural size.

Locality. Dr. Davis's, Pee Dee River.

Museum, College of Charleston.

\section{A M E L L B R A N C H I A T A. - B BAINVILLE.}

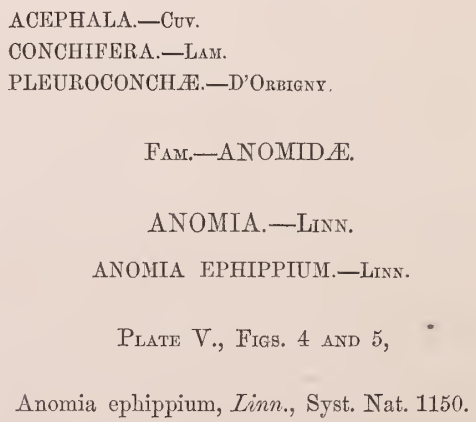

A. testa suborbiculari, irregulari, tenuissima; concentrice striata, sub-lcevigata: foraminc ovato.

Description. Shell somewhat orbicular, irregular, undulating; concentrically striated, or smooth; opening for the byssus large, oval. 
This very irregular shell is abundant in the marls of the State, and particularly on the Waccamaw river. The upper valves often occur in great numbers, one within the other, as shells are frequently seen along the coast, thrown up by the waves. The lower valve, which is more fragile, is rarely found fossil.

It is the only species in the upper tertiary of South Carolina. The genus Avomis, at present an inhabitant of every sea, occurs in the fossil state as far back as the cretaceous period.

Plate V., Fig. 4. Upper valve, natural size.

"5. Side view, natural size.

LOCality. Waccamaw.

Museum, College of Charleston, S. C.

\section{PLACUNANOMIA.-BROD. \\ PLACUNANOMIA PLiCATA.-(New Species.)}

P. testa subovali, subequivalvi, subequilaterali, subfoliacea, tenui; margine ter plicata, impressione musculari magna, semiorbiculari, centrali; valva superiore versus cardinem plana; costis cardinalibus aliquantulum divergentibus.

Description. Shell sub-oval, but variable, sub-equivalve, sub-equilateral, slightly foliated, thin, margin with three or four deep plications; muscular impression large, semi-orbicular central; upper valve flat near the hinge or beaks; the two ribs in the hinge slightly divergent.

We believe this to be the first of the genus that has been found fossil in the United States. In the cabinet of Dr. Edmund Ravenel, of this State, there is a species taken from the harbour of Charleston, belonging to this genus. It is, therefore, living upon the coast of South Carolina.

PLATe VI., FIG. 4. Upper valve, natural size.

" 5. Inside of lower valve, showing the costal ribs of the hinge, the muscular impression, and the perforation for the passage of the organ of attachment.

" 6. Side view of the fossil, natural size, showing the plicated margin.

Locality. Smith's, Goose Creek.

Museum, College of Charleston. 


\section{FAM. OSTRACID E.}

OSTREA.-LINN.

OSTREA VIRGINIANA.-GMEL.

Plate V., Figs. 6, 7, 8 and 9.

Ostrea Virginica, Gmel., Sys. 3336, No. 113. Foss. Shells, Tertiary For. Vol.1, p. 28, Tab. 14, Fig. 2.

O. testa irregulari, oblonga, ovata, crassa; valva inferiore, radiatim plicata, rugosa vel radiatim undulata; valva superiore, subcomplanata lamellosa, vel radiatim plicata.

Description. Shell irregular, ovate oblong, thick; lower valve radiately plicate rugose, or radiatcly undulating; superior valve somewhat flat; lamellar or plicate.

It is difficult to find a characteristic for this exceedingly variable fossil, and in this respect it resembles its living representatives. Sometimes the valves are barely marked by radiating, almost smooth and narrow ridges, and again both valves are strongly plicated, and roughened by coarse raised plates. The beaks are generally pointed, and the ligamental fossa long. For the most part the fossils are thicker and more strongly plaited than the recent forms of this species.

The specimen figured in Plate V., Fig. 7, is related by the markings on the upper valve, to O. sculpturata, Con. Fig. 5 is a very markcd variety, known along the coast of South Carolina as the Raccoon Oyster. It is very long, narrow and coarsely lamellar. Full grown individuals are often seven inches in length, and not more than an inch wide.

This variety has only been found fossil in the Waccamaw, above Conwayboro'. Notwithstanding the great abundance of oysters in all the estuaries along the coast, beds of oyster shells are of rare occurrence in our middle or uppcr tertiary strata, nor have we seen a single such bed in South Carolina; on the contrary, O. Virgrisiand is rather a rare fossil.

Plate V., Fig. 6, resembles that of the recent species known along the coast of South Carotina as the Raccoon oyster.

“ 7. Upper view of variety related to O. Sculpturata, Con.

"8. Lower view of same.

"9. Side view.

Locality. Smith's, Goose Creek; Waccamaw. 
OSTREA RAVENELIANA.-(New Species.)

Plate VI., Figs. 1, 2, 3.

O. testa orbiculata, vel ovata; valva inferiore, convexa, subcostata, lamellosa; valva superiore, lamellosa, maxime depressa, vel concava.

Description. Shell orbicular or ovate, thin; lower valve convex, somewhat ribbed, lamellar; superior valve smooth, lamellar, much depressed, concave; beaks incurved. This shell is almost orbicular when young, but becomes elongated by age.

In the Report on the Geology of South Carolina this fossil is cited as O. DISPARILIS, Con., which it resembles. It differs from it, however, in being in all stages of growth less robust; by having the upper valve almost smooth or covered with thin, scarcely raised lamcllar plates, and by its greater concavity.

Inscribed to Dr. E. Ravenel, of Charleston, one of the earliest cultivators of conchological science in the State, the liberal use of whose cabinet and library no student of science can forget, who has had the good fortune to visit his hospitable residencc.

The genus Ostrea had its beginning in the Triassic, was very numerous in the Jurassic, Cretaceous and Tertiary periods, and has its numerical maximum in the present seas, where it exists at all depths, generally within the limits of tide water, but frequently in deeper soundings.

Plate VI., FIG. 1. Upper view of fossil, natural size.

"2. Lower valve, from the under side.

"3. Side view.

Locatity. St. John's, Berkeley; Smith's, Goose Creek; Grove, Cooper River. 


\author{
FAM. CHAMACID 正. \\ CHAMA.-LINN. \\ CHAMA CORTICOSA.-CoN.
}

Plate VII., Figs. 1, 2, 3.

Chama corticosa, Con., Am. Jour. Sci., Vol. XXIII., p. 341, Foss. Ter. For., p. 32, pl. XVII. fig. 3.

C. testa sinistrorsa, inbricata-lamellosa; valva superiore operculiformi, convexiuscula, radiation striata, valva inferiore convexa, contorta.

Description. Shell sinistral, lamellar, imbricate; upper valve flat or somewhat convex, marked with radiating lines; lower valve convex, contorted. Readily distinguished by its sinistral beaks, and whole surface covered by coarse scales, in concentric layers.

This fossil, so abundant in the Meiocene of Virginia, is quite rare in South Carolina, only a single valve having been found.

Puate VII., Fig. 1. Lower valve, natural size.

"2. View of fossit from above.

"3. Side view of the same.

" 2 and 3 are from the Meiocene of Virginia.

Locality. Darlington District.

Museum, College of Charleston, S. C.

\title{
CHAMA ARCINELLA.-LINN \\ Plate VII., Figs. 4. 5, 6.
}

Chama arcinella, Linn., Sys. Nat. p. 1139.

C. testa orbiculo-cordata; costis radiatim spinosissimis, interstitiis excavato-punctatis.

Description. Shell orbicular-cordate; radiating ribs very spinous; spines strong, recurved, tubular; interstices deep, punctate in young specimens; lunule broadly cordate; buccal side granulated. 
This shell, in the fossil state, is larger than any speeimens that we have seen of the recent form of the speeies; in every other respect it agrees perfeetly with C. ARCiNELLA, of our eoast.

PiATE VII., FIG. 4. Side view of fossit, natural size.

"5. View of interior of lower valve.

"6. Upper view of lower valve.

Locality. Royal Landing, Waceamaw.

Mruseum, College of Charleston, S. C.

\section{CHAMA CONGREGATA.-CoN.}

Plate VII., Figs. 7, 8, 9, 10.

Chama congregata, Con., Am. Jour. Sci., Vol. XXIII., p. 341, Foss. Ter. Form. p. 32, pl. XVII., fig. 2.

C. testa orbiculari, crassa, lamellosa; lamellis numerosis, brevissimis; valva superiore operculiformi; valva inferiore convexa.

Description. Shell orbieular, thiek, lamellar; plates numerous, very short; upper valve operculiform, eovered with numerous short eorrugated seales; lower valve convex, scales more distant, and often with radiating undulations. In some varieties of this fossil, the beaks are produeed, distant and much eurved, resembling the genus Diceras. Both in this and the preeeding species, the lamellæ often fall off, whieh greatly alters the aspeet of the speeimen.

C. CONGREgata is often found in groups cemented together.

The genus CHama makes its appearance in the middle Cretaceous, and is continued into the aetual period, where it abounds.

Plate VII., Fig. 7. Tpper view of fosiz, natural size.

"8. Side view of the same.

"9. Interior of lower valve.

" 10. Interior of upper valve.

Locality. Waeeamaw. 


\title{
FAM. PECTINID无.
}

\section{SPONDYLUS.-GESNER.}

Casts from the shells of this genus are found in the beds on Goose Creek, but are too imperfect for description.

Locality. Goose Creek.

Prof. L. R. Gibbes.

\author{
PLICATULA.-LinN. \\ PLiCATULA Marginata.-SAy. \\ Plate VII., Frgs. 11, 12, 13 axd 14.
}

Plicatula marginata, Say., Jour. Ac. Nat. Sci., Vol. IV., p. 136, pl. 9, fig. 4.

Plicatula marginata, Con., Fos. Ter. Form. p. 75, pl. 43, fig. 5.

P. testa ovato-cuneata, irregulari, crassa, suboequivalvi, radiatim 3-5-costata; costis elevatis, lamellosis.

Description. Shell ovate, wedge-shaped, irregular, thick, nearly equi-valve; radiately three to five costate; ribs elevated, lamellar.

The ribs vary in number, and like its living congener P. Ramosa, it has sometimes, towards the palleal margin, one or two short ribs between the longer ones.

In full grown specimens a raised and slightly crenulated line, borders the margin of the shell on the inside.

From P. RAMosa, Lam., of our Southern coast, it is distinguished by its coarse, lamellar ribs, and greater thickness. The genus Plicatela is found in the lower Jurassic rocks, and occurs through all the intermediate periods, up to the present, in which it inbabits the shallow waters of the ocean in warm climates.

Piate VII., Fig. 11. Upper view of fossil, natural size.

"12. Side view of same.

"13. Front view of same.

"14. Interior of both valves.

Locality. Darlington District, S. C. 


\section{JANIRA.-SCHUMACHER.}

The genus JANIRA was instituted by Schumacher in 1817, to receive such forms of the genus Pecten as have the lower valve, compared with the upper, larger and more convex, the upper valve flat or concave, and both equilateral. The other characters are the same as those of the genus Pecten. Janira seems to connect Pecten with Spondylus.

\section{JANIRA HEMICYCLICA.}

Plate, VIII., Figs. 1, 2, 3, 4 .

Pecten hemicyclicus, Rav.

J. testa sub-semicirculari, depressa, concentrice striata, incequivalvi, cequilaterali; valva inferiore convexa; costis marginem versus sulcatis; valva superiore depressa, costis convexis, sub-incequalibus,

Description. Shell somewhat semi-circular, depressed, striated concentrically and closely; inequivalve, equilateral, lower valve convex, ribs, towards the pallial margin, turned up and sulcate; upper valve depressed, or flat, concave towards the pallial margin, ribs convex; buccal ears depressed, lower one with a stout ridge.

This fine fossil has its living representative in $J_{\triangle N I R A}$ (PECTEN) $J_{\triangle C O B \& A}$, which it greatly resembles, and from which it is distinguished by its less convex lower valve, and by the absence of the radiating and numerous impressed lines of the ribs.

Plate VIII., FIG. 1. Upper valve, natural size.
"2. Lower valve.
"3. Side view of fossil.
"4. Outline of the ribs.

Locality. Grove, Cooper River. 


\section{JANIRA AFFINIS.-(New Species.)}

Plate VIII., Figs. 5 and 6.

P. testa subrotunda, tenui; valva inferiore, convexa oequilaterali, extus loevigata, intus binis radiatim costata; auriculis sub-cequalibus.

Description. Shell almost circular, thin; lower valve convex, equilateral ; smooth on the outside, with radiating undulations or obsolete ribs, striated concentrically; on the inside rayed with narrow ribs in pairs; ears nearly equal. The ribs on the inside correspond with the intermediate spaces of the obsolete ribs on the outside. The buccal ear is slightly expanded and crossed by undulating strix, and with an obtuse ridge terminating in the sinus. Although but a single lower valve has becn found, the wide channel and corresponding ridge, on the outside of the buccal ear, are sufficient to refer it to the genus JANiRA. The thinness of the shell and interior costæ give it some resemblance to P. MorTONI, but it is separated from it by the sinus for the byssus, and greater convexity of the shell.

It also resembles J. Ziczac, of the coast of Florida; the latter, however, has the lower valve more convex, the umbones more prominent, and the flattened external ribs better defined, and marked by an impressed line towards the pallial margin.

The genus JANIRA commenced its existence in the ocean of the cretaceous period, is found in the tertiary, and is still an inhabitant of the seas of warm and temperate climates. Both the tertiary and recent species are of greater size than those of the cretaceous.

Plate VIII., Fig. 5. Under side of lower valve, natural size.

"6. Interior of same.

Locality. Smith's, Goose Creek. 


\section{PECTEN.-GAULTIER.}

PECTEN MORTONI-RAV.

Prates LX. AND X., Figs. 1 то 4.

Pecten Mortoni, Rav., Proc. Acad. Nat. Sci., Vol. II., p. 96.

$P$. testa rotunda, compressa, tenui, cequivalvi, cequilaterali, utrinque hiante; valvis, extus loevibus, aut tenuissime concentrice striatis, intus costis radiatim angustis, binis.

Description. Shell circular, compressed, thin, excepting at the base of the ears, equivalve, equilateral, gaping at both sides, concentrically marked with fine lines on the outer surface; interior sufacc with about thirty-seven narrow ribs, arranged in pairs, prominent along the pallial edge, becoming obsolete with age, towards the hinge, and entirely wanting in the buccal and anal margins.

This fine fossil is not uncommon in South Carolina. It bears a striking resemblance to P. PLeUronectes and P. JAPonicus. From the former it is separated by greater size and regularity of the ribs, and from the lattcr by their lesser number. P. JAPONICUs having from forty-four to forty-six, whilst P. MORTONI rarely exceeds forty; this, however, is a very variable character, and the fossil stands very nearly related to P. JAPONICUs.

Prate LX., Frg. 1. Side view of shell, natural size.

"2. Lower value.

PLATE X., Fra. 1. End view, to show the hinge.

"2. Interior of valve, to show ribs.

Localrty. Grove, Cooper River; Smith's, Goose Creek.

Museum, College of Charleston, S. C. 


\section{PECTEN EBOREUS.-CON.}

Plate XI., Figs. 1 то 5.

Pecten eboreus, Con., Am. Jour. Sci., Vol. XXII., p. 341. 1833. Foss. Ter. Form., p. 48, pl. 23 and 24 , fig. 3.

Pecten Holbrookii, Rav., Proc. Ac. Nat. Sci., Vol. II., p. 96. 1844.

P. testa tenui, orbiculari, depressa, sub-cequivalvi, incequilaterali; 24-26 costis parviusculis, planis, concentrice striatis ; auriculis incequalibus.

Description. Shell orbicular, depressed, valves nearly equal, sub-inequilateral, ribs 24 to 26 , rather flat, with concentric, undulating lines; ears unequal, buccal ear with a deep sinus; lower valve less convex.

This Pecten, although variable, is well marked by the flat, somewhat rough and rather distant ribs, and oblique outline.

Plate XI., Fig. 1. Tpper vatue, natural size.

"2. Lower valve.

"3. Side view of fossit.

"4. Outline of the ribs.

"5. Magnified view of a seetion of the ribs and interstices, showing the concentric undulating lines.

LocALITY. Waccamaw.

Museum, College of Charleston, S. C. 


\section{PECTEN COMPARILIS. - (New Species.)}

Plate XI., Figs. 6 то 10.

P. testa orbiculata, cequivalvi, aequilaterali vel incequilaterali; 23 costis convexis, concentrice striatis; auriculis suboequalibus.

Description. Shell orbicular, convex, somewhat thick, equivalve, with concentric lines of growth, ears nearly equal; lower valve, buccal ear notched, radiately and coarsely ribbed, with five to six ribs; anal ear ribs smaller and more numerous; upper valve, ears with the radiating lines equal; ribs and interstices nearly equal.

This fossil is distinguished from $\mathrm{P}$. EBoreus by having the ribs more raised and convex, both valves more convex, and by the coarse ribs of the buccal ear of the lower valve. Like P. EBoreus, it is also a variable shell, some specimens nearly equilateral, and others very inequilateral. It also bears a strong resemblance to a recent shell from the coast of Florida.

PLATE XI., Fia. 6. Upper valve, natural size.

“7. Lower valve.

“ 8. Side view of shell.

“9. Outline of ribs.

"10. Magnified view of a section of the ribs and interstices, showing the concentric undulating lines.

Locality. Darlington; Smith's, Goose Creek.

Mrseum College of Charleston, S. C. 
. PECTEN PEEDEENSIS.-(New Species.)

Plate XII., Figs. 1, 2, 3, 4, 5.

P. testa trigono-ovata, crassa, cequilaterali; costis 8, ampliter nodosis, concentrice striatis, sub-squamosis.

Description. Shell triangularly ovate, somewhat flatly convex, equivalve, equilateral; with eight large knobbed ribs, the whole concentrically covered with squamose striæ. Lower valve with the ribs generally dislocated vertically, and rather abruptly on the umbones. The interstices between the ribs become very wide towards the pallial margin. The upper valve with ribs strongly knobbed.

Of all the fossil Pectens this is the thickest and most robust. It was first observed by Mr. Ruffin, on the Pee Dee, and the name is that by which he designated it.

It is very closely related to, if not identical with P. xoposus, of the Gulf of Mexico. In the recent shell, the whole surface is marked by strongly impressed radiating lines, whilst in the fossil the surface is covered by radiating and transverse striæ.

Plate XII., Fig. 1. Upper valve, natural size.

"2. Lower valve.

"3. Side view of fossil.

"4. Outline of the form of the ribs at margin.

"5." Magnified view of a portion of a rib, showing the radiating and transverse stria.

Locality. Darlington District.

Museum, College of Charleston, S. C. 


\section{PECTEN SEPTENARIUS.-SAY.}

Plate XIII., Figs. 1, 2, 3 and 4.

Pecten Septenarius, Say, Jour. Ac. Nat. Sci., Vol. IV., p. 36, pl. 9, fig. 3.

P. testa orbiculari, convexa, crassa, subcequivalvi, cequilaterali; costis 6-7, ampliter, radiatim striatis, tranversimque decussatis; intersticiis excavatis, striatis.

Description. Shell orbicular, convex, thick, nearly equivalve, equilateral; ribs 6 to 7 , large, radiately striate, and decussated by transverse lines, somewhat squamose; interstices excavated, striate.

In young shells the ribs are flat, and angular on the edges, which become rounded as they increase in length with age. The ribs on the umbones are worn smooth; but towards the pallial margin, both ribs and interstices, are crossed by closely arranged and sharp squamose lines.

Only a single perfect valve has come into our hands, and this we owe to the politeness of Dr. Harllee, of Darlington District.

Prate XIII., Fig. 1. Lower valve natural size.

"2. Side view of fossit.

"3. Magnified view of a portion of a rib.

"4. Outline of the form of the ribs at margin.

Locality. Near Giles's Bluff, Pee Dee.

Museum, College of Charleston. 


\author{
ORTHOCONCHÆ.—D'ORB. \\ INTEGROPALALA.-D'ORB. \\ DIMYARIA.-LAM.
}

FAM. MYTILID AE.

MYTILUS.-LIN.

MYTILUS INCRASSATUS.-CON.

Plate XIV., Figs. 1 and 2.

Mytilus incrassatus, Con., Am. Jour. Sci., Vol. LXI., p. 247, Foss. Ter. For., p. 74, pl. 42, fig. 4.

M. testa crassa, inflata, arcuata, lcevigata, concentrice lamellosa; lateri buccali sub-arcuato, acuminato; lateri anali dilato, rotundato; umbonibus acutis.

Description. Shell thick, inflated, smooth, with concentric lamellar lines of growth; buccal margin somewhat arched near the umbones, accuminate; anal margin round, somewhat dilated; umbones acute.

This species is remarkable for the thickness of the shell, particularly towards the hinge, and, in this respect, approaches the genus Mroconcha. It is found in North Carolina as well as in South Carolina, but is rare in the latter State.

Plate XIV., Fig. 1. Exterior of fossil, natural size.

"2. Interior of the same. '

Locality. Darlington District and Waccamaw. 


\section{MYTILUS INFLATUS.-(New Species.)}

Plate XIV., Fig. 3.

M. testa inflata, gibbosa, loevigata, concentrice striata; lateri buccali, inflato, angulato ; lateri anali truncato, lateri palliali arcuato.

DescRIPTION. Shell inflated, gibbous, smooth, concentrically striated; buccal side inflated, angulated ; anal side truncate; pallial margin arched.

This fossil bears a strong resemblance to Modiola Ducatelli, Con.; but, after a careful comparison with Conrad's description and figure, we are forced to regard our fossil as a different species. It is more gibbous, the pallial margin is wider and more arcuated; and, above all, it differs from the Maryland fossil in the ratio of the breadth to the length, which is in M. Decatelli 44-100, and in M. inflatus 27-100.

The genus Modiola has been re-united, we think very properly, to Mrrilus. The mere character of the beaks being terminal, or placed on one side, is too variable to render it possible, with any degree of certainty, to separate the two genera.

This genus has inhabited every sea, since the beginning of life, on our globe, and is still found living in vast numbers.

PLATe XIV., Fig. 3. Interior of fossil natural size, imbedded in marl.

Localitry. Giles's Bluff, Pee Dee.

Museum, College of Charleston. 
FAS. ARCACID $A$.

\author{
ARCA.-LINN. \\ ARCA HIANS.-(Neno Species.) \\ Plate XIV., Figs. 4 and 5.
}

A. testa oblonga, compressa, radiatim costata ; latere buccali, brevi, rotundato; latere anali, elongato, sub-compresso, expanso, sub-angulato oblique truncato; latere palliali hiante; dentibus cardinalibus minimis; area ligamenti, excavata, sulcata; umbonibus approximatis.

Description. Shell oblong, compressed, radiately costate, buccal side short, rounded; anal side elongated, dilated, somewhat angulated, truncate; pallial margin gaping ; cardinal teeth small; ligament area deep, channeled; umbones approaching.

The ribs are marked by impressed lines, which become obsolete towards the buccal and anal margins. The whole shell is crossed by incremental lines, which are raised and somewhat squamose towards the pallial margin, and along the hinge line on the anal side. The cardinal teeth are small and irregular, and become, with age, at the extremity of the hinge, mere points. The buccal muscular impression is deep. In old individuals the pallial margin is undulating and toothed, and at all ages gaping towards the buccal side.

Resembles A. propatula, Con., from which it is distinguished by its greater relative length, and by being more angular at the extremities. In A. PROPATULA the ratio of breadth to length is 6-10. This belongs to the genus ByssoARCA, of Swainson. The opening for the byssus is quite large.

Plate XIV., FIG. 4. Exterior of upper valve and hinge and teeth of lower valve.

"5. Pallial margin to show gaping.

LOCALity. Sumter District.

Museum, College of Charleston. 


\section{ARCA INCILE.-SAY.}

Plate XIV., Figs. 6 and 7.

Arca incile, Say, Jour. Ac. Nat. Sci., Vol. IV., p. 139, pl. 10, fig. 8.

Arca incile, Con., Foss. Shells, Ter. For. p. 16, tab. 2, fig. 1.

Arca incile, Con., Foss. Ter. For., p. 56, pl. 29, fig. 5.

A. testa oblique ovata, radiatim costata; costis inequalibus; latere buccali brevissimo; latere anali compresso, angulato, truncato, vix emarginato, carinato; area ligamenti lata; umbonibus incurvis, approximatis.

Description. Shell obliquely ovate, radiately ribbed; ribs unequal, larger on the anal side; buccal side very short; anal side compressed, angular, truncate, nearly emarginate, carinate; umbones incurved, approximating.

The ligament area is crossed at the buccal extremity by close transverse lines, the rest of the area is impressed by the lines of growth parallel with the hinge; teeth regular and oblique towards the anal margin. This fossil is readily distinguished by the much contracted buccal side, which is most striking when the interior of the shell is towards the observer, and by the abruptly compressed and carinated anal side.

PLATE XIV., FIG. 6. Exterior of upper, and interior of lower valve.

"7. End view, to show the hinge.

Locality. Darlington District.

Museum, College of Charleston. 


\section{ARCA C.ALATA-CON.}

Plate XIV., Figs. 8, 9 aND 10.

Arca Colata, Con., Foss. Ter. For., p. 61, pl. 32, fig. 2.

A testa elongata, sub-trapeziformi, compressa, decussatim striata; latere buccali rotundato; latere anali sub-carinato, angulato, oblique truncato; umbonibus incurvis.

Description. Shell elongated, somewhat trapeziform, compressed, decussately striate; buccal side rounded; anal side, somewhat carinated, angular, obliquely truncate; umbones incurved.

The radiating strix are beautifully nodulous, (see mag. sec., fig. 10,) and on the anal side are somewhat squamose. The concentric lines are more strongly marked on the middle of the disks, and together with the radiating striæ become obsolete on the umbones.

This little species is found in the Post Pleiocene of the State, and is probably living on the coast.

Plate XIV., FIG. 8. Fixterior of shell.

"9. Interior of shell.

"10. Magnified view of the strico, showing nodulows ribs.

Locality. Darlington District. 


\section{ARCA CENTENARIA.-SAY.}

Plate XIV., Figs. 11 and 12.

Arca Centenaria, Say, Jour. Ac. Nat. Sci., Vol. 4, p. 138, pl. 10, fig. 2.

Arca Centenaria, Con., Foss. Shells, Ter. For., p. 16, tab. 1, fig. 4.

Arca Centenaria, Con., Foss. Ter. For., p. 55, pl. 29, fig. 4.

A. testa ovato-quadrata, radiatim striata; striis numerosis, confertis; margine palliali excavato; area ligamenti ampliori, striata.

Description. Shell ovately square, radiately striate; striæ, numerous, close; pallial margin contracted; ligament area somewhat wide, striate.

This shell is sufficiently well characterized by the numerous and somewhat irregular radiating lines, which are alternately larger and smaller. The surface is rendered uneven by concentric, undulating lines of growth, and the pallial margin is strongly contracted.

It is a common species in the Mciocene of Virginia, but is very rare in South Carolina.

Plate XIV., FIG. 11. Exterior of upper and interior of lower valve.

"12. Side view of fossit.

Locality. Sumter District.

Museum, College of Charleston. 
NOTE ON THE GENUS ARCA

D'Orbigny has, we think properly, re-united to ARCA the genera Byssoarca and CuculLEA, as only modifications of that genus. As for the character dependant on the teeth, it varies so widely in ARCA as to render it often difficult, if not impossible to fix the limits between this genus and Cucullea.

The gaping species were referred to BYssoARCA, under the impression that such alone had a byssus, but this is not the case; we have ourselves dredged up in Tampa Bay groups of ArCa traxsversa, a closed species, attached to dead shells by a byssus. The gaping species, according to D'Orbigny, lose the byssus with age.

The genus ARCA is first found in the Silurian rocks, and has its greatest developement in the existing seas. 


\section{ARCA RUSTICA.-(New Species.)}

\section{Plate XV., Fig. 1.}

A. testa crassa, sub-quadrata, radiatim costata; costis sub-squamosis; latere buccali brevioribus, costis crenatis; latere anali carinato, angulato, truncato, costis majoribus; umbonibus inter se fere contingentibus.

DesCRIPTION. Shell thick, somewhat square, radiately, and unequally ribbed; ribs almost squamose; buccal side very short, ribs crenate; anal side carinate, angular, truncate, ribs very large; ligament area narrow, umbones nearly touching.

This fossil is readily distinguished by the coarse ribs and deeply excavated interstices on the anal side. The margin is strongly crenulated. Only a single perfect valve has been found, with a fragment of a larger individual, which is presented in Fig. 1.

Plate XV., FIG. 1. Fragment of the only specimen in our possession. The outline is correct. A perfect shell, though much smaller, was lost after the outline of Fig. 1 had been taken.

LOCALITY. Waccamaw.

Museum, College of Charleston. 
ARCA LIENOSA.-SAX.

Plate XV., Figs. 2 and 3.

Arca Lienosa, Say., Say's American Conchology, plate 36.

A. testa oblonga, obliqua, inflata, costata, transversim rugosa; latere buccali producto, angulato; latere anali elongato, oblique truncato; costis incequalibus sulcatis; area ligamenti lata sulcata, umbonibus distantibus.

Description. Shell oblong, oblique, inflated, ribbed, transversely rugose, buccal side produced, angular; anal side elongated, obliquely truncate; ribs unequal, channelled; ligament area wide sulcate; umbones distant.

The ligament area is bounded on the outer side by a short carina, crossed by close lines, which are well defined towards each extremity. The sulci of the area are not regularly diverging, but somewhat parallel to the hinge. The ribs in young shells are impressed by a line to which others are added, after the shells have attained a certain size; the ribs are larger on each extremity of the shells, and on the buccal side are about equal to the interstices. The concentric lines of growth are raised and prominent towards the margin, and in old specimens become even rugose. This species occurs recent on the coast of Florida.

Plate XV., FIG. 2. Fxterior of left valve, and hinge and teeth of right valve.

"3. Fnd view, showing outline of hinge and umbones.

LocAlity. Tilley's Landing, Waccamaw.

Museum, College of Charleston. 


\section{ARCA IMPROCERA.-CON. \\ Plate XV., Figs. 4 and 5.}

Arca improcera, Con., Foss. Ter. For., p. 60, pl. 31, fig. 5.

A. testa oblonga radiatim costata, latere buccali brevi, rotundato, superne angulato; latere anali, angulato, oblique truncato; costis valvo dextralis crenulatis; valvo sinistralis, costis ad laterem buccalem crenulatis ad laterem analem loevibus; area ligamenti angusta, sulcata; umbonibus approximatis.

Description. Shell oblong, radiately costate; buccal margin short, rounded, angular above; anal side angulated, obliquely truncate; ribs on the right valve crenulate; on the left valve crenulate on the buccal side, smooth on the anal side; ligament area short, narrow, furrowed; umbones approximating.

This pretty species is distinguished by the short hinge line which forms angles with the sides; the anal side is somewhat produced and angulated, with the ribs flattened and smooth.

Plate XV., Fig. 4. Exterior of left valve, and hinge and teeth of right valve.

“5. End view, showing outline, hinge and umbones.

Locality. Darlington District. 
ARCA TRANSVERSA.-SAY.

Plate XV., Figs. 6 and 7.

Arca Transversa, Say., Jour. Ac. Nat. Sci. Vol. II., p. 259.

Arca Transversa, Say., Foss. Shells. Ter. For., No. 2, p. 15, tab. I, fig. 2.

A. testa elongato-ovata; latere buccali breviore, subangulato; latere anali elongato, angulato; area ligamenti angusta sulcata, umbonibus depressis, approximatis.

Descriprion. Shell elongately ovate; buccal side shorter, somewhat angulated above; anal side elongated, angular; area of the ligament narrow, furrowed.

The young shell, as described by Say, has the right valve with the ribs all nodulous; in the left only those on the buccal side are thus ornamented. With age these characters are rendered less striking, and the shell becomes less regular.

The elongated form of this shell distinguishes it pretty well from its congeners. It is, however, very variable, yet through all its variations the undulating depressions upon the umbones, which to their very points, can always be perceived. Fig, 6 represents a variety which is well marked both in the recent and fossil state. The umbones are less compressed, and the whole shell more rounded and irregular.

Plate XV., Fig. 6. Exterior of left valve and hinge and teeth of right valve.

"7. End view, showing outline of hinge and umbones.

Locality. Darlington District.

Museum, College of Charleston. 


\section{ARCA SCALARIS.-CON.}

Plate XVI., Figs. 1 and 2.

Arca Scalaris, Con., Proc. Ac. Nat. Sci., Vol. I., p. 324.

Arca Scalaris, Con., Foss. Ter. For., p. 59, pl. 31, fiig. 1.

A. testa ovata, obliqua, radiatim costata; costis quatuor et viginti; latere buccali brevi; latere anali oblique producto; costis, valva dextralis, nodoso-crenatis, valva sinistralis oblique crenatis; area ligamenti brevi, sublata.

Description. Shell ovate oblique, radiately ribbed, ribs twenty-four; buccal side short; anal side obliquely produced; ribs of the right valve nodulously crenulated, of the left valve obliquely crenulated; ligament area short, somewhat wide.

This fossil seems closely allied to the preceding species. The points of difference are, however, very considerable. Besides attaining a greater size, A. SCALARIs is more oblique, has the ribs on the right valve larger and more strongly crenulated; whilst on the left valve, the ribs are coarsely crenulated on the buccal margin, flattened in the middle of the valve, and covered with oblique crenulations. Both valves are carinated towards the anal margin.

PLATE XVI., FIG. 1. Exterior of left valve, hinge and teeth of right valve.

"2. End view of fossil, showing outline, hinge and umbones.

Locality. Darlington District. 
ARCA FQUICOSTATA.CON.

Plate XVI., Figs. 3 and 4.

A. testa ovata, inflata: latere buccali brevi, rotundato; latere anali sub-elongato; costis valvo sinistralis rotundatis, latere anali crenulatis; valvoe dextralis, costis sub-planis; dentibus cardinalibus numerosis; area ligamenti sulcata, sublata; umbonibus elevatis distantibus.

Description. Shell ovate, inflated; buccal side short, rounded; anal side somewhat elongated; ribs of the left valve rounded, crenulated on the anal side; ribs of the right valve somewhat flat; cardinal teeth numerous; ligament area channelled, rather wide; umbones elevated, distant.

This is a pretty well marked species, that can only be confounded with A. IMPROCERA, from which it is separated by its more rounded outline, greater size, and more produced anal side.

PLate XVI., Fig. 3. Exterior of left valve, hinge and teeth of right valve.

“4. End view of fossil, showing outline, hinge and umbones.

Locality. Sumter Dist.

Museum, College of Charleston. 


\section{ARCA INCONGRUA - SAY}

Plate XVI., Figs. 5 and 6.

A. testa sub-quadrato-orbiculari, inoequivalva, radiatim costata; latere buccali breviore; valvce sinistralis costis sub-crenatis, valvo dextralis costis omnibus crenatis. Area ligamenti latiuscula; umbonibus approximatis.

Description. Shell somewhat squarely orbicular, inequivalve, radiately ribbed, ribs about twenty-eight; buccal side shorter, left valve with the ribs somewhat crenulated on the buccal and anal margins; ribs on the right valve all crenulated; ligament area rather wide; umbones somewhat approximating.

This, although one of the most common of our coast shells, is very rare in the fossil state.

Plate XVI., FIG. 5. Eaterior of left valve, and hinge and teeth of right valve

"6. End view of fossit, showing outline of hinge and umbones.

Locality. Darlington District.

Museum, College of Charleston. 
ARCA PEXATA.-SAY.

Plate XVI., Figs. 7 and 8.

A. testa suborbiculari; lateribus rotundatis; latere buccali breviore; radiatim costata; costis medio sulco exile divisis; area ligamenti angustissima ; umbonibus fere inter se contingentibus.

Description. Shell somewhat orbicular, sides rounded; buccal side the shorter; ribs divided in the middle by a groove; ligament area very narrow; umbones nearly touching.

With the exception of A. Americana, Gray, and A. Holmeseir, Kurtz and Stimson, this is the only species having the hinge line terminating at the umbones. Only a single valve of this shell, so common an inhabitant of our coast, has been found fossil, and even this is not a very characteristic specimen, as it is somewhat distorted, having undergone repairs by the animal. We, therefore, give the figure of a recent specimen.

Puate XVI., Fig. 7. Exaterior of left valve, hinge and teeth of right valve.

“ 8. End view, showing hinge and umbones.

Locality. Darlington District.

Museum, College of Charleston. 


\title{
PECTUNCULUS.-LAM.
}

\author{
PECTUNCULUS SUBOVATUS.-CoN.
}

Plate XVII. Fig. 1.

Pectunculus subovatus, Con., Jour. Ac. Nat. Sci., Vol. 4, p. 140.

Pectunculus subovatus, Con., Foss. Shells, Ter. For., p. 17, tab. 2, fig. 3.

Pectunculus subovatus, Con., Foss. Ter. For. p. 62, pl. 34, fig. 1.

P. testa subovata, compressa, subequilaterali; costis depressis, distantibus; interstitiis convexis; latere palliali concentrice sublamelloso; area ligamenti ampliori, striata; umbonibus incurvis.

Descriprion. Shell subovate, compressed nearly equilateral; ribs flattened, distant; interstices convex; pallial margin concentrically somewhat lamellose; ligament area rather wide, striate.

On the buccal side the ribs are more prominent, and impressed by a radiating line, and towards the anal and pallial margin they become almost obsolete in full-grown specimens. The teeth are regularly $V$ shaped, and increase in size towards the beaks. Beaks small and but slightly prominent. Ligament area moderately wide and marked by divaricating lines; in the young stage the margin is crenated, but this almost disappears with age.

A very common specimen in the Meiocene of Virginia.

Plate XVII. Fig. 1, Exterior left valve; interior, hinge and teeth of right valve.

Locality. Darlington. 
PECTUNCULUS LENTIFORMIS.-CoN.

Plate XVII. Fig. 2.

Pectunculus pulvinatus, Lam., Con., Foss. Shells, Ter. For., p. 17, tab. 2, fig. 2.

Pectunculus lentiformis, Con., Foss. Ter. For., p, 64, pl. 36, fig. 2.

P. testa sub-orbiculari, crassa, sub-aquilaterali, costata, radiatim tenuiter striata; concentrice plicata; dentibus cardinalibus, crassis; area ligamenti striata.

Description. Shell nearly orbicular, thick, almost equilateral; ribbed, radiately and finely striate; concentrically plaited; cardinal teeth robust, oblique; ligament area wide, striate.

The orbicular outline of this shell is greatly modified by age; the sides became thickened and contracted, so that the buccal and anal margin appear to be slightly truncate. The concentric increment lines become more numerous towards the pallial margin. The teeth occupy about two-thirds of the hinge plate. The greater thickness of the shell and the robust teeth, will serve to separate this fossil from its congeners.

Plate XVII. Fig. 2, Exterior of left valve, and interior, hinge and teeth right valve.

Locality. Darlington.

Museum, College of Charleston.

PECTUNCULUS PASSUS.-CoN.

Plate XVII. Fig. 3.

Pectunculus passus, Con., Foss. Ter. For., p. 64, pl. 35, fig. 3.

P. testa sub-orbiculata, sub-aquilaterali; latere buccali, costis evanescentibus, umbonibus inter se fere contingentibus.

Description. Shell sub-orbicular, radiately striate; ribs disappearing in the buccal margin; umbones nearly touching 
Cardinal teeth coarse, oblique. The greatest length of the shell is towards the umbones, which gives the shell a somewhat auriculated contour; a character which distinguishes the species from both P. Tricenarius and P. Parilis. From the former it is also distinguished by its more robust teeth. Occurs in the Meiocene of Petersburg, Va., and in North-Carolina.

Plate XVII. Fig. 3, Exterior left valve; interior, hinge and teeth of right valve.

Locality. Sumter District.

Museum, College of Charleston.

PECTUNCULUS QUINQUERUGATUS.-CoN.

Plate XVII. Fig. 4.

Pectunculus quinquerugatus, Con., Am. Jour. Sci., Vol. 4, p. 346.

Pectunculus quinquerugatus, Con., Foss. Ter. For., p. 63, pl. 34, fig. 3.

P. testa tenui, sub-orbiculata, sub-cquilaterali, radiatim tenussime striata; costis depressis; umbonibus, latere buccali rugato.

Description. Shell thin, nearly orbicular, almost equilateral, concentrically wrinkled, radiately and very finely striate; ribs depressed; buccal side of the umbones wrinkled.

This fine species is the largest of the genus found in our tertiary rocks. It is thin for its size. The teeth are rather small, curved upon a narrow hinge-plate. But the singular characteristic which separates it from the other species, is the wrinkles on the side of the umbones. It occurs also in North-Carolina.

Plate XVII. Fig. 4, Exterior of left valve; interior, hinge and teeth of right valve.

Locality. Waccamaw.

Museum, College of Charleston. 


\section{PECTUNCULUS LAVIS.-(New Species.)}

Plate XVII. Fig 5.

P. sub-ovali, crassa, incquilaterali concentrice striata vel sulcata; latere buccali rotundato; latere anali sub-producto, oblique truncato; dentibus numerosis; labro crenato.

Description. Somewhat oval, thick, inequilateral, concentrically striate, or grooved; buccal margin rounded; anal side somewhat produced, obliquely truncate; lip crenato.

The teeth extend without interruption around the hinge. The pallial and muscular impressions are well defined, and in young individuals the shell is slightly angular near the umbones. Umbones pointed and closely approximating.

This is the only species of this genus, without radiating ribs, found in our newer Tertiary rocks.

Plate XVII. Fig. 5, Exterior of left, and interior, hinge and teeth of right valve.

Locality. Waccamaw.

\section{PECTUNCULUS ARATUS.-Con.}

Plate XVit. Figs. 6, $6 a$ and $6 b$.

Pectunculus aratus, Con., Am. Jour. Sci., Vol. 41, p. 346.

Pectunculus aratus, Con., Foss. Ter. For., p. 62, pl. 3, fig. 2.

P. testa sub-ovali, sub-aquilaterali; costis elevatis; latere buccali truncato; dentibus cardinalibus numerosis; labro crenato; area ligamenti striata.

Description. Shell somewhat oval, nearly equilateral; ribs clevated; buccal side truncate; cardinal tecth numcrous, lips crenate. 
This little shell, which is closely related to if not identical with a recent species of the coast of Florida, is readily distinguished by its prominent rather rough ribs, short hinge, and truncate buceal margin. The teeth are numerous, and uninterrupted. Ligament area small.

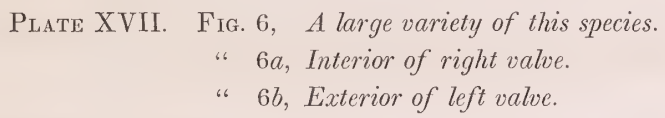

Locality. Darlington District.

Museum, College of Charleston.

\section{PECTUNCULUS TRANSVERSUS.-(New Species.)}

Plate XVII. Fig, 6c.

P. testa ovato-transversa, aquilateralis; latere anali interne rugato, margine palliali tenuiter crenulata.

Description. Shell ovate transverse, equilateral; anal side on the interior wrinkled; pallial margin finely crenulated.

This specimen, although a cast, is so very characteristic that it cannot be confounded with any other species. The length is nearly twice the breadth, and the teeth are closer on the anal than on the buccal ridge of the hinge.

Plate XVII. Fig. $6 c$.

Locality. Goose Creek.

Museum, College of Charleston.

The genus Pectunculus which had its maximum development in the seas of the actual period, had its origin in the seas of the lower cretaceous period. 


\author{
I U C U L I I) E. \\ N U C U L A. - L A M. \\ N U C U L A L I M A T U L A. - SAY. \\ PLATE XVII. Figs. 13 to 15.
}

Nucula limatula, Say, Amer. Conch, pl. 12.

Nucula limatula, Say, Foss. Ter. For., p. 57, pl. 30, fig. 4.

Nucula limatula, Say, Conrad's Am. Marine Conch., p. 30, pl. 6, fig. 1.

N. testa elongata, compressa, lavigata, polita, incequilateralis; latere buccali rotundato; latere anati angusto, sub-recurvo; lunula lineata.

Description. Shell elongated, compressed, smooth, polished, inequilateral; buccal side rounded; anal side narrow, somewhat recurved; lunule linear.

In the Tertiary of South-Carolina there are no forms of this genus with which this species can be confounded. Its smooth surface, elongated form, and regularly carinated pallial margin, are sufficiently characteristic. Occasionally a few obsolete concentric lines may be seen on the disks, and one or two on the anal margin, towards its extremity.

It occurs fossil both in Virginia and North-Carolina. Although found living in considerable numbers on the coast of South-Carolina, it is quite rare in the Tertiary of the State.

Plate XVII. Fig. 13, Exterior of night value.

" 14, Interior of left valve.

" 15, Magnified hinge and teeth.

Locality. Sumter District.

Museum, College of Charleston. 
N U U U L A PliOX I M A.-SAY.

Plate XVII. Figs. 7 то 9.

Nucula proxima, Say, Jour. Ac. Nat. Sci., Vol. 2, p. 270.

Nucula obliqua, Say, (non. Lam.) Am. Jour., Vol. 2, p. 40.

Nucula proxima, Say, Conrad's Am. Marine Conch., p. 31, tab. 6, fig. 2.

N. testa ovata, lavigata, concentrice rugosa; latere buccali brevissimo; latere anali subelongato obtuso; lunula cordata, sub-obsoleta; labro crenato.

Description. Shell ovate, smooth, concentrically wrinkled; buccal margin very short; anal side somewhat elongated, obtuse; lunule cordate almost obsolete; lip crenate.

The very short buccal side, and pearly interior are conspicuous characters of this beautiful little shell. It belongs to the actual fauna of our coast, and is also found fossil in the Meiocene of Virginia.

We have placed N. obliqua, Say, as a synonyme of this species, having but little doubt of their identity.

PLate XVII. FIG. 7, Interior of right valve.

" 8, Exterior of left valve.

" 9, Magnified hinge and teeth.

Locality. Darlington District.

Museum, College of Charleston.

N U C U L A A C U T A. - S A Y

Plate XVII. Figs. 10 to 12.

Nucula acuta, Con., Conrad's Am. Marine Conch., pl. 6, fig. 3.

Nucula acuta, Con., Foss. Ter. For., p. 57, pl. 30, fig. 2.

N. testa sub-lanceolata, incequilateralis, concentrice striata; latere buccali brevi, rotundato; latere anali producto, rostrato, sub-recurvo; hunula lanceolata. 
Description. Shell somewhat lanceolate, inequilateral, concentrically striate; buccal side short, rounded, inflated; anal side produced, beaked, somewhat recurved; lunule lanceolate.

This little species, which is also an inhabitant of our coast, occurs in the Meiocene of Virginia. It is easily distinguished by its rostrated anal side and regularly striated surface.

Plate XVII. Fig. 10, Exterior of right valve.

" 11, Interior of left valve.

" 12, Magnified vien of hinge and teeth.

Locality. Darlington District.

Museum, College of Charleston.

The genus Nucula occurs in the Silurian rocks, and has continued an inhabitant of every sea up to the present time.

\section{LUCINID E.}

\section{LUCINA.-BRUGUIERE.}

L U C I A CONTRACTA.-SAY.

Plate XVili. Fig. 1.

Lucina contracta, Say, Jour. Ac. Nat. Sei., Vol. 4, p. 145, pl. 10, fig. 8.

Lucina contracta, Say, Foss. Ter. For., p. 40, pl. 20, fig. 5.

L. testa orbiculata, inflata, concentrice incqualiter costata; interstitiis striatis; latere anali subflexuoso-excavato; latere buccali subangulato; lunula lanceolata.

Description. Shell orbicular, inflated concentrically and unequally ribbed; interstices striated; anal margin somewhat flexuosely channeled; buccal margin somewhat angular above; lunule lanceolate. 
In this well-defined species, the whole shell, which is rather thin, is covered with elevated lines of growth, the spaces between which are covered with fine concentric striæ. The beaks approximate, and the inner surface of both valves is covered with radiating lines.

It occurs sparingly in the Meiocene of Virginia, and is found living along the eastern coast, as far north as Rhode Island.

Plate XVIII. F1G. 1, Interior of right and exterior of left valve.

Locality. Darlington District.

LUCINA ANODONTA--SAY.

Prath XVIII. Fig. 2.

Lucina anodonta, Say, Jour. Ac. Nat. Sci., Vol, 4, p. 146, pl. 10, fig. 9.

Lucina anodonta, Say, Foss. Ter. For., p. 39, pl. 20, fig. 4.

L. testa crassa, compressa, sub-rotundata, concentrice rugosa; latere anali rotundo; latere buccali fluxuoso, sub-angulato; lunula excavata.

DESCRIPTION. Shell thick, compressed, nearly orbicular, with concentric wrinkled strix; anal side round; buccal margin somewhat angular; lunule excavated.

This shell, though readily distinguished from the other species of the genus, is somewhat variable. In the young state it is thinner and more compressed.

Towards the buccal side, an irregular radiating ridge extends from the umbones to the pallial margin, and a similar, but shorter one, is often found on each side of the lumule. Two obsolete folds occur on the anal side of the valves. On the inside there is a callus, resembling a rough muscular impression, which extends from the elevated interior edge of the hinge-plate to the buccal muscular impression, giving the cavity, at the beaks, an angular appearance. 
Mr. Conrad supposes this species identical with his L. Floridaxi, a recent species from the Florida coast, which we have not seen.

Occurs abundantly in the Meiocene of Virginia, but is rather rare in South-Carolina.

Plate XVIII. Fig. 2, Interior of right and exterior of left valve.

LocalitT. Waccamaw.

Museum, College of Charleston.

LUCINA PENNSYLVANICA.-LINN.

P'late XVIII. Fig. 3.

Venus Pennsylvanica, Limn, Sys. Nat., (Ed. Tur.) Vol. 4, p. 232.

Lucina Pennsylvanica, Lam., (Ed. 3rd) p. 574.

Lucina Pennsylvanica, Sorv., Sow. Gen., No. 27, fig. 4.

Lucina Pennsylvanica, Reeve, Reeve's Con. Icon., pl. 4, fig. 29.

L. testa sub-globosa, crassa, solida, concentrice multilivata; latere anali sulcato-excavata, lunula ampla oblongo-cordata impressa.

Description. Shell sub-globose, thick, solid, concentrically ribbed; anal side with a conspicuous channel; lunule impressed, oblong, cordate.

This is a well-characterised species. The deep channel on the anal side, which produces a notch in the pallial margin, the flat concentric ribs on the disks, the well-defined ovate lunule, and the angle on the buccal side, are characters that distinguish this species from all its congeners.

With age, the shell becomes very thick, and the muscular impressions deep. Towards the pallial margin the lines of growth become somewhat lamellese.

Reeve gives a figure of a specimen from Jamaica, and seems to doubt its existence on our coast, but occasionally a valve is picked up on the coast of South-Carolina; and on the southern coast of Florida it is one of the most common shells.

Plate XVIII. Fig. 3, Interior of right and exterior of left valve.

Localits, Darlington District.

Museum, College of Charleston. 
L U U I A RA D I N S. - UOX.

Plate XVIII. Figs. 4 AND 5.

Lucina radians, Con., Am. Jour. Sci. and Arts, Vol. 41, p. 347.

Lucina radians, Con., Foss. Shells, Ter. For., p. 70, pl. 40, fig. 3.

L. testa orbiculata, convexa, concentrice striata; radiatim obsolete irregulariter striata; lunula excavata.

Description. Shell orbicular, concentrically and regularly striate; radiately and obsoletely striate; lunule excavated.

The beaks are prominent and acute, the concentric lines are close and well-defined, and the radiating lines are somewhat irregular, and on the anal side are more distant and prominent. L. multilineata resembles the young of this species, but the radiating lines are more regular and the shell more convex than in the species under consideration.

This pretty species is living on the coast of North and South Carolina, and is abundant in the Post Pleiocene. It is readily distinguished by its prominent umbones, close and regular concentric striæ and obsolete rather irregular radiating lines.

\section{Plate XVIII. Fig. 4, Interior of right valve. \\ " 5, Exterior of left valve.}

Localiter. Darlington District.
L U C I A SQUA II OSA.-LA .

Plate XVIII. Figs. 6 and 7.

Lucina squamosa, Lam., An. Sans. ver., Vol. 5, p. 542.

Lucina squamosa, Con., Foss. Ter. For., p. 38, pl. 20, fig. 1.

Lucina speciosa, Rogers, Trans. Amer. Phil. Soc., new series, Vol. 5, p. 333, fig. 1.

Lucina squamosa, Con., Foss. Ter. For., p. 38, pl. 20, fig. 1.

L. testa convexa, inequilateralis, radiatim costata; latere anali brevi; latere buccali subproducto. 
Description. Shell convex, inequilateral, radiately ribbed; anal margin short; buccal margin somewhat produced.

The radiating ribs are sometimes bifurcated; lines of growth prominent on the disks; beaks contracted and prominent.

The compressed and oblique form of this shell, together with the small but well-defined radiating ribs, distinguish it from its congeners.

This species is found living along the coast of North and South Carolina; nor is it very uncommon in the Meiocene of Virginia.

$$
\begin{aligned}
& \text { Plate XVIII. Fig. 6, Interior of right valve. } \\
& \text { " 7, Exterior of left valve. }
\end{aligned}
$$

Locality. Darlington District.

Museum, College of Charleston.

\section{U C I A CRIBRARIA.-SAY. \\ PLATE XVIII. Figs. 8 AND 9.}

Lucina cribraria, Say, Jour. Ac. Nat. Sci., Vol. 4, p. 147, pl. 13, fig. 1.

Lucina cribraria, Con., Foss. Ter. For. pl. 3, fig. 1.

L. testa orbiculata, convexa, radiatim tenuiter costata, concentrice elevato-lamellosa; latere anali flexuoso; lunula sub-impressa.

Description. Shell orbicular, convex, radiately and finely ribbed; with concentric elevated lamellæ; anal side flexuose; lunule somewhat impressed.

This common species is distinguished by the rather distant, prominent lamellæ on the umbones, which become more numerous and closer towards the pallial margin, giving that part of the shell a decussated appearance. 
Found in the Meiocene of Virginia, where it is quite abundant.

Plate XVIII. Fig. 8, Interior of right valve.

" 9, Exterior of left valve.

Locality. Darlington District.

Museum, College of Charleston.

L UCINA DIVARICATA.- LAM.

Plate XVIII. Figs. 10 and 11.

Tellina divaricata, Linn

Lucina divaricata, Lam., An. sans. Ver., Vol. 4, p. 541.

Lucina divaricata, Con., Fos. Ter. For., p. 39, pl. 20, fig. 3.

L. testa orbiculari, sub-globosa, tenui; bifariam sulcato-striata; striis divartcatıs.

Description. Shell orbicular, somewhat globose, thin, groove-striated in two directions, striæ divaricate.

This pretty species is easily distinguished from its congeners, by its regular outline and sharply cut divaricating striæ.

It is difficult to believe a species to have so wide a distribution, both horizontally and vertically, as this is said to have. It occurs in the Eocene of Europe, in the Meiocene of Virginia, in South-Carolina in both Pleiocene and Post Pleiocene, and belongs to the living fauna of our entire coast.

It is very possible that several species are included under this specific name.

Plate XVIII. Fig. 10, Interior of right valve.

" 11, Exterior of left valve.

Locality. Waccamaw.

Museum, College of Charleston. 
L U C I N A C OSTATA.-(Nero Species.)

Pr.ate XVIII. Figs. 12 and 13.

L. testa orbiculata, crassa, compressa, radiatim costata, concentrice striata, sub-sulcata; latere anali squamoso.

Description. Shell orbicular, thick, compressed, radiately ribbed, concentrically striate, and towards the pallial margin somewhat sulcate.

This fossil is readily distinguished from the small uuciside which it resembles, by the proninent rounded ribs.

It occurs in great abundance in the Post Pleiocene beds near Charleston, although it has not as yet been found amongst the living fauna of the State.

Plate XVIII. Fig. 12, Natural size.

" 13, Magnified.

Locality. Black River.

Museum, College of Charleston.

I U CINA CRENULATA. - CoN.

Plate XVIII. Figs. 14 and 15.

Lucina crenulata, Con., Foss. Ter. For., p. 39, pl. 20, fig. 2.

L. testa rotundata, inflata, concentrice lamellata; latere anali sub-flexuoso; lunula subexcavata.

Description. Shell orbicular, inflated, concentrically lamellated, lunule slightly excavated.

This little species is readily distinguished by its orbicular outline and the closely arranged concentric lamellæ; the lunule is short and deep. 
It is distinguished from L. muLtmiNeata, which it resembles, by the absence of radiating lines.

It is quite common in the Meiocene of Virginia, and is living along the coast from the Chesapeake to Florida.

$$
\begin{aligned}
& \text { Plate XVIII. Fig. 14, Natural size. } \\
& \text { “ 15, Magnified. }
\end{aligned}
$$

Locality. Darlington.

Museum, College of Charleston.

LUCINA II ULTILINEATA.-Cox.

Plate XVIII. Figs. 16 and 17.

Lucina multilineata, Con., Foss. Ter. For., p. 71, pl. 40. fig. 6.

L. testa rotundata, concentrice tenuiterque lirata, radiatim striata.

Description. Shell orbicular, concentrically and closely ribbed, radiately striate.

This little fossil has the outline and general characters of L. crenulata, from which it can only be distinguished by the radiating lines which give the shell a cancellated appearance.

It occurs in the Post Pleiocene, and is often confounded with L. crenulata.

Plate XVIII. Fig. 16, Natural size.

" 17, Magnified.

Locality. Waccamaw. 
L U C I N A T R I S U L C T A.-- CoN.

Plate XViII. Figs. 18 and 19.

Lucina trisulcata, Con., Foss. Ter. For., p. 71, pl. 40, fig. 5.

L. testa ovata, convexa, incquilaterali; concentrice striata, sulcata; lunula cordata, profunde excavata.

Description. Shell ovate, convex, inequilateral ; concentrically striate and channelled; lunule cordate, deeply excavated.

This fossil resembles L. CRendlata; but it is readily distinguished from that species by its less orbicular outline, its prominent and more oblique beaks, and above all, by the short but very deep lunule, which extends under the beaks.

The concentric sulci which suggested the specific name to Mr. Conrad, are accidental, quite variable in number and position, and in the larger number of individuals they are absent altogether.

The short and deep lunule will serve to characterise all the varieties of the species.

Plate XVIII. Fig. 18, Natural size.

" 19, Magnified.

Locality. Darlington District.

The genus Lucina is found as low in the geological series as the devonian system, and has its greatest development in the seas of the present period. 


\section{CARDIAD E.}

\section{CARDIUM.-BRUGUIERE.}

CARDIU II AI A N M.-BORN,

Plate XIX. FIg, 1.

Cardium Magnum, Born., Test. Mus. Coes. Vind, pl. 3, fig. 5.

Cardium Maculatum, Gmelin, Conch. Icon., pl. 4, fig. 20.

Cardium Ventricosum, Bruguiere, Lam., Vol. 6, p. 400.

C. testa maxima, ventricosa, oblique cordata, latere anali sub-angulato-depresso, radiatim costato; costis planulatis, buccalis crenulatis.

Description. Shell very large, inflated, obliquely cordate; anal side somewhat angularly depressed; radiately ribbed, ribs flattened, buccal ribs crenulated.

This shell presents some variation in form; some individuals are more ventricose, whilst others present a greater disproportion between the length and height.

In young specimens, the crenulations on the ribs on the buccal side are not always prominent, but after they attain to a height of an inch or two they appear and are very persistent. The buccal ribs are somewhat angular, with the angles turned towards the anal side.

The specimen figured might easily be confounded with C. LAquEatum, Con., of the Meiocene of Virginia; but the very regular flat crenulations on the buccal ribs in C. MAGNuM will serve to distinguish the two.

Although this is one of the most common recent shells of the coast, and is very abundant in the Post Pleiocene, it is quite rare in our Tertiary beds. The single valve figured, and the fragment of a full-grown individual, are all that have hitherto been found.

Plate XIX. Fig. 1.

Locality. Darlington District.

Museum, College of Charleston. 


\title{
C A R D I M M UR I CA T U Y. - L IN .
}

\author{
Plate XIX. Fig, 2
}

Cardium muricatum, Linn., Sys. Nat., p. 1123.

C. testa cordata-ovata, sub-obliqua, radiatim costata; costis convexis, tuberculis minutis compressis.

Descriptron. Shell cordately ovate, somewhat oblique, radiately ribbed, ribs convex, muricated with minute compressed obliquely arranged tubercles.

The muricated ribs serve to distinguish this from the other Tertiary species which it may resemble. On the buccal side of the shell, the ribs have the tubercles on the anterior side; these are followed by a few ribs muricated on both sides; and on the anal side the tubercles are turned backward.

C. MURTCatun occurs sparingly on the coast of South-Carolina, and living specimens are rarely found; nor is it more abundant amongst the fossil forms of the State.

Plate XIX. Fig. 2, Interior of right and exterior of left valve, natural size.

Locality. Darlington District.

Iuseum, College of Charleston.

C A R D I U M S U B L I N E A T U II. - CON

Plate XIX. Fig. 3.

Cardium sublineatum, Con., Am. Jour. Sci., Vol. 41, p. 347, pl. 2, fig. 13.

Cardium sublineatum, Con., Foss. Ter. For., p. 66, pl. 37, fig. 4 .

C. testa obliqua ovata, tenui, sub-ventricosa, radiatim tenuissime striata; marginibus intus crenulatis. 
Description. Shell obliquely ovate, thin, somewhat ventricose, radiately, very finely striated; margins finely crenulated within.

This fossil resembles some forms of C. SERratum, living on the coast of Florida; but it is less ventricose, especially towards the pallial margin. The anal side is also much less curved.

Both valves of this shell are often found in juxtaposition, and the polish of the surface scarcely destroyed.

Plate XIX. Fig. 3, Interior of right and exterior of left valve, natural size.

Locality. Waccamaw and Darlington District.

Museum, College of Charleston.

The genus CARDium is found in the upper Silurian rocks, and represented in greatest number of species in the actual or present period.

\section{CARDITIDE.}

\section{CARDITA.-BRUGUIERE.}

CARDITA A R A T A.

Plate Xis. Figs. 4 and 5.

Cypricardia arata, Con., Foss. Shells, Ter. For., p. 20, pl. 5, fig. 1.

Carditamera arata, Con., Foss. Ter. For., p. 12, pl. 6, fig 2.

C. testa ovato-oblonga; costis transversim-radiantibus, rotundatis nodulosis; latere buccali brevissimo; latere anali truncato.

Description. Shell ovately oblong; ribs transversely radiated, rounded, noduloes; buccal side very short; anal truncated. 
The rounded and prominent ribs are distinctly crenulated. Pallial margin nearly straight.

This is doubtless the fossil described by Conrad, which he says "clearly resembles one of the Florida coast," and it is really difficult to distinguish some forms of this species from C. Floridana, Con.

We have followed D'Orbigny in uniting Carditamera with Cardita.

PLATE XIX. FIG. 4, Exterior of left valve, natural size.

" 5, Interior of right valve.

Locslity. Darlington District.

Museum, College of Charleston.

CA R I TA GRANULATA.-Sar.

Plate XIX. Figs, qane ?. +8

Venericardia granulata, Say, Jour. Ac. Nat. Sci., Vol. 4, p. 142, pl. 12, fig. 1.

Cardita granulata, Say, Foss. Shells, Ter. For., p. 12, pl. 7, fig 1.

C. testa sub-orbiculata, oblique cordata, crassa, inequilaterali, radiatim costata, concentrice striata.

Description. Shell nearly orbicular, obliquely cordate, thick, inequilateral, radiately costate, concentrically striated.

This is one of the most common fossils of the Tertiary beds of Virginia and South-Carolina. It is readily distinguished by its neatly rounded outline. The anal side is rounded, with a larger curve than that of the buccal side. The beaks are acute and curved forward. The ribs are granulated above, and rather wrinkled towards the pallial margin. Inner margin coarsely crenulated.

PLATE XIX. FIG. ${ }^{7} 6$, Interior of right valve, natural size.

" $8 \%$, Exterior of left valve, natural size.

Locality. Sumter.

Museum, College of Charleston. 
CARDITA TRIDENTATA.-SAY.

\section{Plate XIX. Figs. 8-a*a 9. $\forall / 0$}

Cardita tridentata, Say, Jour. Ac. Nat. Sci., Vol. 5, p. 216.

Cardita tridentata, Con., Foss. Ter. For., p. 76, pl. 43, fig. 11.

C. testa rotundata trigona, crassa; radiatim costata; costis elevatis, cremulatis.

Description. Shell round, triangular, thick, radiately ribbed; ribs elevated, strongly crenulated.

This little species is distinguished by its sub-triangular outline, thick, robust and coarsely crenulated ribs. The beaks are slightly turned forward. There are two teeth in the left, and one in the right valve.

The species is an inhabitant of the sonthern coast, and we have never found larger specimens.

Plate XIX. Fig. 8 , Interior of right valve.
" $\$ \phi$, Exterior of left valve, natural size.

Locality. Sumter District.

Museum, College of Charleston.

\section{CARDITA CARINATA.}

\section{Plate XIX. Fig. 10. 6}

Carditamera carinata, Con., Proc. Ac. Nat. Sci., Vol. 1, p. 305.

Carditamera carinata, Con., Foss. Ter. For., p. 65, pl. 37, fig. 1.

C. testa elongato-ovata; latere buccali brevissimo; costis transversis radiantibus, angulatis, muricato-squamosis.

Description. Shell ovately oblong, buccal side very short; ribs radiating transversely, angular muricated and squamose. 
This is a well-marked species. On the anal side, the ribs are rounded, and two or three on the angle are robust, squamose, and imbricated. The middle ribs are flat, with an impressed line; and the angles crenulated. On the buccal side, the ribs are rounded and closely crenulated by the lines of growth.

Plate XIX. Fig. To, Interior of right and exterior of left valve.

LocaliTy. Waccamaw.

Museum, College of Charleston.

C A R D TA PERPLANA

Plate XIX. Fig. 11

Cardita perplana, Con., Am. Jour. Sci., Vol. 41, pl. 2, fig. 16.

Astarte radians, Con., Foss. Ter. For., p. 77, pl. 43, fig. 13.

C. testa trigona, inequilaterali, plana, radiatim costata, concentrice striata; umbonibus acutis; latere anali elongato; latere buccali brevi.

DEScription. Shell triangular, inequilateral, radiately ribbed, concentrically striated; umbones, anal side produced, buccal side short.

A few prominent lines of grow th often mark the disks, and the ribs on the anal side are curved. The ribs are few and not closely arranged. The straight buccal margin, and very flat form, separate this fossil from every other species of the genus.

Plate XIX. Fig. 11, Natural size.

L.ocality. Waccamaw.

Museum, College of Charleston. 
Cardita abbreviata, Con., Am. Jour. Sci., Vol. 41, pl. 2, fig. 17. Astarte abbreviata, Con., Foss. Ter. For., p. 77, pl. 43, fig. 12.

C. testa parva, ovato-trigona, obliqua, convexa, radiatim costata; costis crenatis, umbonitus acutis.

Description. Shell small, ovately triangular, oblique, radiately ribbed; ribs crenate, umbones acute.

Resembles the young of C. GRANULATA, but is much more elevated, has the ribs more closely arranged, and in outline is more oblique than in C. Granulata, Say.

We have restored this and the preceding species to the genus CARDita, under which they were first described by Conrad. We are not aware that any radiately ribbed species belong to the genus AstaRTE, and moreover, the additional buccal muscular impression is wanting in these species.

Plate XIX. Fig. 12, Natural size.

Locality. Waccamaw. 


\author{
ASTARTIDE. \\ ASTARTE.-SOWERBY. \\ A S T A R T E U N U L A T A. - S AY. \\ Plate XX. Figs. 1 and 2.
}

Astarte undulata, Say, Jour. Ac. Nat Sci., Vol. 4, p. 150, pl. 9, fig. 5.

Astarte undulata, Con., Foss. Ter. For. p. 41, pl. 20, fig. 4.

A. testa sub-trigona, incequilateralis; umbonibus depressis, recurvis, sulcatis; sulcis irregularibus, latissimis.

Description. Shell somewhat triangular, inequilateral; umbones flat, recurved, furrowed; furrows irregular, very wide.

The broad furrows on the umbones of this shell distinguish it from the other species. The furrows vary in number, and sometimes almost cover the valves; but this is rare. The sudden curvature of the umbones gives the buccal slope a gibbous outline, and this character is preserved in all the varieties.

Plate XX. FIG. 1, represents a common variety.

"2, Another variety, natural size.

Locality. Sumter District.

Museum, College of Charleston. 
Astarte concentrica, Con., Jour. Ac. Nat. Sci., Vol. 7, p. 133.

Astarte concentrica, Con., Foss. Ter. For., p. 44, pl. 21, fig. 6.

A. testa trigona, depressa, sub-equilateralis, concentrice sulcata; sulcis regularibus; umbonibus acutis, recurvis; margine tenui crenato.

Description. Shell triangular, depressed, nearly equilateral, concentrically furrowed, furrows regular; umbones acute, recurved; margin crenate.

This species is the most constant in form of this variable genus; but it is readily distinguished by the regular and closely arranged furrows which cover the entire shell.

Plate XX. FIG. 3, Interior of right and exterior of left valve, natural size.

Locality. Waccamaw. 


\section{ASTARTE LUNULATA.-CoN.}

Plate XX. Fig. 4.

Astarte lunulata, Con., Foss. Ter. For., p. 44, pl. 21, fig. 8.

A. testa parva, depressa, sub-trigona, concentrice sulcata; latere buccali truncato; latere anali sub-angulato.

Description. Shell small, flat, somewhat angular, concentrically furrowed; buccal margin truncated; anal margin somewhat angular.

This little species is at once known by the regular and angular furrows; straight sides, and prominently arched pallial margin, which is within smooth.

It occurs living on the coast of South-Carolina and in the Gulf of Mexico.

Plate XX. Fig. 4, Natural size.

Locality. Darlington District.

Museum, College of Charleston.

The genus Astarte is found living in the seas of cold regions, and existed in great numbers in the Liassic seas. 


\title{
CRASSATELLA.-LAM.
}

\author{
CRASSATELLA UNDULATA.- SAY.
}

Plate XX. Figs. 5 to 8.

Crassatella undulata, Say, Jour. Ac. Nat. Sci., Vol. 4, p. 142, pl. 11, fig. 2.

Crassatella undulata, Con., Foss. Shells, Ter. For., p. 23, pl. 9, fig. 1.

Crassatella undulata, Con., Foss. Ter. For., p. 21, pl. 9, fig. 2.

C. testa sub-trigona, crassa, incequilateralis; umbonibus sulcatis, depressis; latere buccali brevi; latere anali elongato, producto, oblique truncato; lunula lanceolata, excavata.

Description. Shell somewhat triangular, thick, inequilateral; umbones sulcate, flattened; buccal side short; anal side elongately produced, obliquely truncated; lunule lanceolate, excavated.

This fine species is subject to great variation in the form of the shell. In one variety, which is the most common, the anal side is greatly produced, making the shell very inequilateral; this prolongation takes place only after the shell has aftained to a certain size. In another variety, the shell is nearly equilateral, and between these extremes, intermediate forms are found. In the young of all, however, the flat, sulcate, umbonal parts are always preserved.

Compare the young of both species as figured in plate XX, figs. 7 and 10.

Plate XX. Fig. 5, Interior of right valve.

" 6, Exterior of right valve.

" 7, Young shell.

“ 8, Variety.

Locality. Sumter District. 
C R A S A T E L L A G B B ESII.-(Nero Species.)

Plate XX. Figs. 9 and 10.

C. testa sub-trigona, crassa, concentrice sulcata; latere buccali rotundato; latere anali subrostrato, angulato, longitudinaliter unicostato; umbonibus incurvis; lumula sub-excavata.

Description. Shell somewhat triangular, thick, concentrically furrowed; buccal side rounded; anal side somewhat beaked, angular, with a longitudinal ridge; umbones incurved; lunule somewhat excavated.

This well-defined species is easily distinguished from any of the varieties of the preceding species. The umbones are much incurved and more inflated than in any form of $\mathrm{C}$. undulata. It differs from the Virginia and Maryland species in its more symetrical form and greater regularity of the sulci, which mark the entire surface of the shell. The ridge on the anal side is prominent, and produces an undulation which extends to the centre of the shell.

The species is very constant in its characters in every stage of growth. Fig. 10 represents a young shell.

We have great pleasure in inscribing this species to our friend and co-laborer, Professor L. R. Gibbes, of the College of Charleston.

Plate XX. FIG. 9, Exterior of left valve.

" 10 , Young shell.

Locality. Waccamaw.

Museum, College of Charleston.

The living species of Crassatella are inhabitants of warm climates. The genus is first found in the Cretaceous system, and has its greatest development in the Tertiary. 


\section{SI N U P A L L I.A L I A.}

\section{CORBULII) A}

\section{CORBULA.-BRUGUIERE.}

C ORBULA CUNEATA.-SAY.

Plate XX. Fig. 11.

Corbula cuneata, Say, Jour. Ac. Nat. Sci., Vol. 4, p. 152, pl. 13, fig. 3.

Corbula cuneata, Con., Foss. Shells, Ter. For., p. 5, pl. 3, fig. 2.

C. testa elongato-ovata, cancentrice striata; latere buccali rotundato; latere anali acuto, sub-rostrato.

Description. Shell elongately ovate, concentrically striate; buccal side rounded; anal side acute, somewhat rostrate.

This neat species is easily distinguished from its congeners of this formation, by the greater regularity of the striæ, and by its more elongated anal side.

It is a rare species in the Pleiocene of South-Carolina, although abundant in the living fauna of the coast.

Plate XX. Fig. 11, Natural size.

LOCALITY. Waccamaw.

\section{Museum, College of Charleston.}

The genus Corbula is found as low as the Jurassic rocks, and is very numerously represented in the seas of the present time. 
C ORBULA INEQUALE.-SAY.

$$
\text { Plate XX. Fig. } 12 .
$$

Corbula inequale, Say, Jour. Ac. Nat. Sci., Vol. 4, p. 153, pl. 13, fig. 3.

Corbula inequale, Con., Foss: Ter. For., p. 6, pl. 3, fig. 3.

C. testa ovato-trigona, incequivalvi, concentrice sulcata; latere buccali rotundato; latere anali angulato sub-carinato.

Description. Shell ovately trigonal, inequivalve, concentrically furrowed; buccal side rounded; anal side angulated, somewhat carinated.

The concentric ridges are irregular in size, and undulating in direction. The anal side, though short, is very acute, and the whole aspect of the shell is different from C. CUNEATA. This shell is abundant in the Meiocene of Virginia.

Plate.XX. Fig. 12, Natural size.

Locality. Waccamaw.

Museum, College of Charleston.

\section{PANDORA.-BRUguiERE.}

PANDORA TRILINEATA. - SAY.

Plate XX. Fig. 13.

Pandora trilineata, Say, Jour. Ac. Nat. Sci.

P. testa ovato-oblonga, incquilateralis; latere buccali rotundato, latere anali arcuato, rostrato; rostro bicarinato.

Description. Shell ovately oblong, inequilateral; buccal side rounded, anal side beaked; beak bicarinate. 
A single rather imperfect valve is all that we have as yet found in the State. It is sufficiently well preserved, however, to leave no doubt of its specific identity, with the recent species of the coast. Conrad has described two species of this genus, P. crassiDens and P. Arenosa, from the Meiocene of Virginia, but the present species cannot be confounded with either of these.

Plate XX. Fig. 13, Natural size.

Locality. Darlington District.

Museum, College of Charleston.

The genus Pandora appears for the first time in the Eocene, is found in the overlying formations, and exists in greatest number in the seas of the present period.

\section{CYCLASIDE.}

\section{CYRENA.-LAM}

C Y RENA DENSATA.-CoN.

Plate XX. Fig. 14

Cyrena densata, Con., Foss. Ter. For., p. 68, pl. 39, fig. 2.

C. testa crassa, sub-trigona, convexa, aquilaterali, concentrice obsolete-striata; latere buccali rotundato; latere anali sub-truncato; margine palliali arcuata; umbonibus elevatis.

Description. Shell somewhat triangular, thick, convex, concentrically and obsoletely striated; buccal side rounded; anal side somewhat truncated; pallial margin regularly arcuated.

The species bears some resemblance to Cyrena Carolinensis of the coast, but differs from it in being less inflated, in outline less orbicular, and by- the prominent beaks, which are narrower and less erected than in the recent species. 
Cyrena densata occurs in the Meiocene of Virginia. In South-Carolina, more perfect specimens are found, but the valves are always separated.

The occurrence of this fossil is an interesting evidence of the existence of estuaries during the Pleiocene period.

D'Orbigny has united under Cyclas, the genera Cyrena and Pisidium.

Plate XX. Fig. 14, Interior of right and exterior of left valve, natural size.

Locality. Darlington District.

Museum, College of Charleston.

The genus is represented in the Oolite, and is found in great numbers in the fauna of the present period.

\section{VENERIDE.}

VENUS RILEYI.-CON.

Plate XXI. Fig. 8.

Venus Rileyi, Con., Foss. Ter. For., p. 9, pl. 6, fig. 1.

V. testa ovata, sub-ventricosa, crassa, incquilaterali, concentrice rugosa; latere anali elongato; latere buccali brevi; lunula ovata.

Description. Shell ovate, somewhat ventricose, thick; anal side elongated; buccal side short; lunule ovate.

This is one of the largest species, and often attains to double the dimensions of the individual figured. It is distinguished from other species by being much more equilateral.

When the recurved lines of growth are preserved, it is rough on the exterior, but where these are removed the surface is rather smooth and concentrically striated. The beaks are compressed, and there is a broad obsolete fold on the anal margin. 
Conrad says of this species that probably it has been confounded with V. TR1DAcNoIDEs. However this may be, it certainly often shows a tendency towards the characteristic folds of V. TRIDACNOIDES.

Plate XXI. Fig. 8, Natural size.

Locality. Waccamaw.

Museum, Collegc of Charleston.

VENUS METASTRIAT.-D'ORB.

Plate XXI. Figs. 1 and 2.

Venus metastriata, d'Orb., Prod. de Paléontologie, Vol 3, p. 108, No. 2020.

Cytherea metastriata, Con., Foss. Ter. For., p. 14, pl. 8, fig. 5.

V. testa sub-aquilaterali, triangulari, concentrice striata; striis concentricis irregularibus, latere anali et buccali radiatim striatis, medio lavigato.

Description. Shell nearly equilateral, triangular, concentrically striate; striæ irregular; anal and buccal sides radiately striate; middle of the shell smooth.

This little fossil is easily identified by its equilateral form and the radiating lines on the buccal and anal sides only. The concentric lines are almost obsolete on the umbones, but towards the pallial margin they are more deeply impressed. I $t$ is abundant in the fossil state and occurs recent on the Atlantic shores of South-Carolina and Florida.

Plate XXI. Fig. 1, Natural size.

" 2, Magnified view, with outline natural size.

Locality. Pee Dee.

Museum, College of Charleston. 
Venus subnasuta, d'Orb., Prod. de Paléontologie, Vol. 3. p. 108, No. 2024.

Cytherea subnasuta, Con., Pro. Ac. Nat. Sci., Vol. 1, p. 28.

Cytherea subnasuta, Con., Foss. Ter. Form., p. 72, pl. 41.

C. testa triangulari, ventricosa; latere buccali angustato, extremitate sub-producta, subangulata; superficie rugosa, rugis concentricis; margine anali oblique arcuato; natibus distantibus a margine anali.

Description. Shell triangular, ventricose; buccal side narrowed, slightly produced and sub-angulated at the extremity; anal margin obliquely arched; 'beaks distant from anal margin.

Venus subnasuta is allied to V. sayana of Conrad, but is proportionally longer, less ventricose, narrower, and more produced on the buccal side.

Plate XXI. FIG. 3, Magnified figure, with outline natural size.

Locality. Pee Dee.

Museum, College of Charleston.

\section{VENUS REPOSTA.-D'O в в.}

Plate XXI. Fig. 4.

Venus reposta, d' Orb., Prod. de Paléontologie, Vol. 3, p. 108, No. 2022.

Cytherea reposta, Con., Foss. Ter. For., p. 15, pl. 9, fig. 2.

Cytherea reposta, Con., Jour. Ac. Nat. Sci., Vol. 7, p. 132.

V. testa magna, ovata, sub-crassa, sub-convexa; natibus prominentibus; margine dorsali depressa, sub-arcuata; margine anali sub-rotundata; hnula magna lanceolata. 
Description. Shell large, ovate, moderately thick and convex; beaks prominent; dorsal margin depressed, slightly arcuated; anal margin obtusely rounded; lunule large lanceolate.

Plate XXI. Fig. 4, Natural size.

Locality. Pee Dee.

Museum, College of Charleston.

VEN US MERCENARIA.-LINN.

Plate XXI. Fig, 6.

Venus mercenaria, Linn., Syst. Nat., 1131.

Venus mercenaria, Gmelin, Syst., 3231.

Venus mercenaria, Lam., An. sans. Vert., Vol. 6, p. 346, pl. 263.

V. testa solida, obliqua cordata, concentrice sulcata, radiatim striata; latere anali subelongato; latere buccali brevi; umbonibus incurvis; lunula cordata.

Description. Shell solid, obliquely cordate, concentrically furrowed, radiately striate; anal side somewhat produced, angled; buccal side short; umbones recurved; lunule cordate.

The anal slope is comparatively straight, and where it joins the pallial margin it is slightly produced into a flattened lip.

This species attains a considerable size, and then resembles V. PERMaGna, but the buccal side in the latter is a portion of a curve of shorter radius, and the whole shell is covered with raised lines of growth.

This common shell of our entire coast is very rare in the Tertiary beds of the State, where a few separate valves only have been found.

Plate XXI. Fig. 6.

Locality. Darlington District.

Museum, College of Charleston. 


\section{VENUS CONCENTRICA. - G SEL.}

Plate XXI. Fig. T..

Venus concentrica, Gmel., p. 3286, No. 82.

Artemis concentrica, Born., Sow. Gen., fig. 4.

V. testa orbiculari, convexo-depressa, sub-aquilaterali; concentrice striata; striis confertis; lunula minima, cordata.

Description. Șhell orbicular, convex, depressed, nearly equilateral; concentrically striate; striæ closely arranged; lunule small, cordate.

- This species is remarkable for its orbicular outline, depressed form, and although the concentric striæ are very regular, there are portions of the disks raised concentrically. The buccal margin is regularly rounded, the anal side somewhat straight, and occasionally sub-truncate. In some varieties of the species, an obsolete, narrow, corrugated fold extends from the umbones to the pallial margin. The hinge plate is broad, and the disposition of the teeth resembles that in the genus Lucina quite as much as in the genus to which it is referred.

We have carefully compared this with the recent form of the species so common along the Southern coast, and can find no essential difference between them. The fossil varies considerably, but a similar range of variation may be traced in the recent forms of the shell.

Plate XXI. Fig. 7, Natural size.

Locality. Sumter District. 
VENUS SAYANA. - D'ORB.

Plate XXI. Frg 9.

Cytherea convexa, Say, Jour. Ac. Nat. Sci., Vol. 4, p. 149, pl. 12, lig. 3.

Cytherea Sayana, Con., Foss. Ter. For., p. 13, pl. 7, fig. 3.

Cytherea convexa, Gould, Inv. Mass., p. 84, fig. 49.

Venus Sayana, d’ Orb., Prod. de Paléontologie, Vol. 3, p. 108, No. 2011.

V. testa sub-cordata, ventricosa, concentrice striata, incequilaterali; latere buccali subangulato; umbonibus prominentibus, incurvis, labro levigato; lunula cordata.

Description. Shell sub-cordate, inflated, concentrically striate, inequilateral; buccal side somewhat angular; umbones prominent, incurved, margin smooth, lunule cordate.

This species is very distinct from its congeners; its smooth surface distinguishes it from the other fossil veneridæ in every stage of growth. It was described by Say under the name of Cytherea convexa, a specific name pre-occupied; it was, therefore, changed to SAYANA, by Conrad.

V. SAYANa is rot uncommon in the Meiocene of Virginia, and occurs recent along our entire coast.

Plate XXI. FIG. 9, Interior of right and exterior of left valve.

Locality. Darlington District.

Museum, College of Charleston.

VENUS CRIBR $\Lambda$ RIA.-CON.

Plate XXI. Fig. 10 .

Venus cribraria, Con., Proc. Acad. Nat. Sci., Vol. 1, p. 310.

Venus cribraria, Con., Foss. Ter. Form., p. 67, pl. 38, fig. 2.

$V$. tesia sub-trigonali, sub-ventricosa; costis 25 , concentricis, lamellosis, elevatis, recurvis, subtus striis transversis instructis; lunula cordata laminata; margine intus crenulata. 
Description. Shell sub-trigonal, slightly ventricose; ribs about 25 , concentric, lamelliform, elevated, recurved, with elevated transverse striæ on the inferior side of each; lunule cordate laminated; inner margin crenulated.

This species occurs recent on the coast of South-Carolina, and is often found in the Post Pleiocene beds of this State.

Plate XXI. Fig. 10, Interior of right, and exterior of left valve, natural size.

Locality. Waccamaw. Darlington.

Museum, College of Charleston.

VENUS CANCELLATA. - L IN .

Plate Xxi. Fig. 11.

Venus cancellata, Linn., Sys. Nat., Ed. 12, p. 11-30.

$V$. testa crassa, sub-depressa, decussata, radiatim striata, concentrice sulcata; sulcis remotis, incqualibus, elevatis; latere anali lamelloso; dentibus cardinalibus crassis, lunula cordata, margine crenulata.

Description. Shell thick, somewhat compressed, decussated, radiately striate, concentrically sulcate; furrows remote, unequal, elevated; anal side lamellar; cardinal teeth thick; lunula cordate; margin crenulated.

This common shell of our coast is readily distinguished by the raised, concentric and remote lines of growth. The radiating striæ are alternately larger and smaller. On the anal margin, the elevated lines of growth become somewhat squamose. The pallial sinus is very short; lunule broadly cordate. This shell cannot be confounded with V. Elevata, which is more inflated and has the lines of growth more regularly disposed and more approximating.

Plate XXI. Fig. 11.

Locality. Sumter District.

Museum, College of Charleston. 
VE N US LATILIR A T A.-Cor.

Plate XXI. Fig. 12.

Venus latilirata, Con;, Proceed. Ac. Nat. Sci., Vol. 1, p. 28.

Venus latilirata, Con., Foss. Ter. For., p. 68, pl. 38, fig. 3.

Venus paphia, Lam., (fossil.)

$V$. testa trigona, sub-cordata, sub-compressa, obliqua, concentrice costata, costis crassissimis, crenulatis; lunula ovato-cordata, striata; margine crenulata.

Description. Shell trigonal, sub-cordate, somewhat compressed, oblique, concentrically ribbed, ribs very thick, flat, crenulated below; lunule ovately cordate, striate; margin crenulated.

The large, flat, irregular ribs characterise this fossil. The ribs are recurved, and terminate suddenly at the anal side. The ligament area is lanceolate and deep.

Plate XXI. Fig. 12, Natural size.

LocaLity. Waccamaw.

Museum, College of Charleston.

VENUS TRIDACNOIDES.-CON.

Plate XXII. Fig. I.

Cyprinifa tridacnoides, Lam., An. sans. Ver., Vol. 5, p. 55 . $58 /$

Venus diformis, Say, Jour. Ac. Nat. Sci., Vol. 4, p. 148, pl. 12, fig: 2.

Venus tridacnoides, Con., Foss. Ter. For., p. 10, pl. 7, fig. 2.

V. testa ovato-cordata, crassissima, concentrice corrugata, radiatim plicata.

Description: Shell ovately cordate, very thick, concentrically wrinkled, radiately plaited. 
This fine species is easily distinguished from its congeners, so well represented in our newer Tertiary formations. The prominent folds, radiating from the beaks to the pallial margin, separate it from every other species of the genus. In other respects it is subject to variation. In some specimens the folds extend quite to the beaks, and in others, they do not commence till after the shell has attained an inch or two in height. The shell is often inflated and ponderous, whilst in other forms it is more or less compressed, with the anal side prolonged, resembling in outline V. RILEYı. The radiating folds are also subject to variation in form and position. In some varieties, the folds are few and prominent, terminating at the margin in deep notches, which suggested the specific name TRIDACNordes, whilst in others the folds are reduced to mere undulations, which extend over the entire shell.

We have a specimen of V. PERMagna, Con., before us, in which a similar fold extends across the shell.

V. TRIDACNoides, though rare in South-Carolina, is quite abundant in the Meiocene beds of Virginia.

Plate XXII. Fig. 1, Natural size.

Locality. Darlington District.

Museum, College of Charleston.

VENUS PERMAGNA.(?)-CON.

PL.ATE XXII. FIG, 2.

Venus permagna, Con., (obs. on V. Mortoni,) Foss. Ter. For., p. 8.

V. testa ovuta, cordata, sub-inflata, concentrice mgoso-striata, latere unali sub-plicuto, arcuato; margine palliali crassi, lavi; lunula impressa, oblongo-cordato.

Description. Shell thick, ovate, cordate, somewhat inflated, concentrically and roughly striate; anal side, with obsolete folds, arcuated; pallial margin thick, smooth, lunule impressed, oblong-cordate. 
This fossil we refer, with hesitation, to V. permagna, Con., a species which he has named but not described; at least we have not been so fortunate as to find any such description. It was originally referred by him to V. MorToni, a species which is fossil in the Post Pleiocene and recent on the coast. From this it is at once separated by its less prominent and less recurved beaks, by its somewhat lanceolate lunule, by being less inflated and differing altogether in outline. V. PERMAGNA has the anal side regularly arcuated, and two obscure folds extend to the thick and somewhat lamellar lip. The outline of the shell is remarkable for its regularly ovate form. The shell is covered with closely arranged lines of growth. The margin is smooth, and if this be a constant and not an accidental character, it may serve to distinguish this species from all the large VENERID \&.

V. PERMAGNA resembles V. RiLeYi more nearly than any other species. Like the latter, it is very inequivalve, but differs from it chiefly in the less prolonged anal side and in its neatly oval outline.

Plate XXII. Fig. 2, Natural size.

Locality. Waccamaw. Museum, College of Charleston.

PETRICOLA.-LAM.

PETRICOLA PHOLA DIFORMIS.-- LAM

Plate XXI. Fig, 5 .

Petricola pholadiformis, Lam., An. sans Ver., 3rd Ed., Brux., Vol. 2, p. 551

Petricola pholadiformis, Gould, Inver. Mass., p. 63.

Petricola fornicata, Say, Jour. Acad. Nat. Sci., Vol. 2, p. 319.

P. testa elongata, cylindrica; latere buccali brevissimo, radiato, costato et striato; costes lamellosis; latere anali elongato, striato, lunula ovata.

Description. Shell elongated, cylindrical, buecal side very short, radiately and striate; ribs lamellar; anal side much elongated, radiately striate; lunule ovate.

This species bears some resemblance to Protas costata, both in the form of the shell, 
and the lamellar character of the ribs, but the form of the hinge as well as the widely gaping posterior extremity of $\mathrm{PHoLAS}$ separate the two genera.

The shell is ovate-cylindrical, equivalve, but very unequilateral; the buccal side is rounded, and covered with irregular lamellar and somewhat toothed ribs; anal side covered with radiating irregular raised lines. The lunule is defined by the termination of the lines of growth.

Petricola pholadiformis is common on the sea coast of this State.

Plate XXI. Fig. 5.

Locality. Pee Dee; and Smith's Goose Creek.

Museum, College of Charleston.

\author{
TELLINA.-LiNN. \\ T E L L I N A B I P L I C A T A.- C ON. \\ Plate XSII, Figs. 3 and $3 a$.
}

Tellina biplicata, Con., Foss. Ter. For, p. 36, pl. 19, fig. 4.

Tellina biplicata, Con., Jour. Ac. Nat. Sci., Vol. 7, p. 152.

Tellina biplicata, d'Orb., Prod. de Paléontologie, Vol. 3, p. 103, No. 1914.

T. testa subovali, inequivalvi, sub-ventricosa, lineis radiantibus inconspicuis, striis tenuissimis, prominentibus precipue in lateris posterioris plicis; plicis duabus angularibus, una valvis singulis distributa; margine cardinali profunde sulcata.

Description. Shell suboval, inequivalve, slightly ventricose with obscure radiating lines, and prominent filiform striæ, much elevated over the folds of the posterior side; folds two, one on each valve, angular; hinge margin profoundly sulcated posteriorly.

Plate XXII. Fig. 3, Exterior of right valve, natural size.

" 3 a, End vien of fossil, to show hinge.

Locality. Pee Dee.

Museum, College of Charleston. 
TELLINA A L TER A TA. - S A Y.

Plate XXII. Fig. 4.

Tellina alternata, Say, Jour. Ac., Nat. Sci., Vol. 2, p. 275. 1822

T. testa compressa, oblonga, antice angustiore et angulata; lineis numerosis parallelis, equalibus, equidistantibus, impressis, concentricis, ad marginem anteriorem alternatim obsoletis; areis interstitialibus planis.

Description. Shell compressed, oblong, narrowed and angulated before; numerous parallel, equal, equidistant, impressed concentric lines, which on the anterior margin are alternately obsolete; interstitial spaces flat.

A callous line which is sometimes obsolete, passes from behind the hinge to the inner margin of the posterior cicatrix, and another from before the hinge to the inner margin of the anterior cicatrix. Anterior hinge-slope declining in a somewhat concave line to an obliquely truncated tip.

This is a common species, living on the coast of South Carolina and Georgia, and not unfrequent on the beach of Florida.

Plate XXII. Fig. 4, Natural size.

Locality. Waccamaw; Smith's, Goose Creek.

Museum, College of Charleston.

TELLI A L U SORIA.-CON

Plate XXII. Fig. 5.

Tellina lusoria, Con., Foss. Ter. For., p. 35, pl. 19, fig. 3.

Psammobia lusoria, Say, Jour. Ac., Nat. Sci., Vol. 5, p. 316.

T. testa elliptica, parte posteriore plicata et reflexa; margine dorsali posteriore recta, obliqua; umbonibus extremitati posteriori truncata approximatis; margine basali arcuata. 
Description. Shell elliptical with a distinct fold near the posterior extremity; posterior end reflected; posterior dorsal margin straight, oblique, extremity truncated and much above the line of the base; beaks nearest the posterior end; basal margin very regularly arched.

Mr. Say described this species from a recent specimen found on the coast of South Carolina; Mr. Conrad says it is also found on the coast of New Jersey.

Plate XXII. FIG. 5, Interior and exterior of fossil, natural size.

Locality. Waccamaw; Pee Dee.

Museum, College of Charleston.

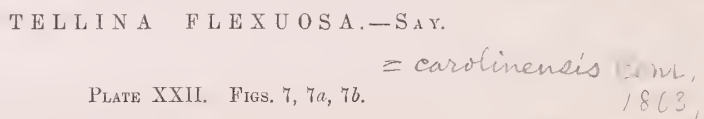

Tellina flexuosa, Say, Jour. Ac. Nat. Sci., Vol. 2, p. 303.

T. testa sub-orbiculari; lineis obliquis, parallelis impressis sculpturata; rugis transversis minutis; margine buccali anali longiore, eaque minus obtuse rotundata; umbonibus pone medium positis.

Description. Shell sub-orbicular, surface obliquely sculptured, with very regular, parallel impressed lines; longitudinal striæ none; transverse wrinkles minute; buccal margin longer than anal and less obtusely rounded; beak placed behind the middle, not prominent.

This very pretty little Tellina is abundant on the southern coast.

PLate XXII. Fig. 7, Magnified view, to show the oblique parallel lines.

" $7 a$ and $7 b$, Interior and exterior of shell, natural size.

Locality. Pee Dee.

Museum, College of Charleston. 
TELLINA POLITA.-SAY.

Plate XXII. Fig. 6.

Tellina polita, Say, Jour. Ac. Nat. Sci., Vol. 2, p. 276.

T. testa transverse sub-triangulari, minute et concentrice rugosa; margine buccali ventrali breviore; margine basali subrecta.

Description. Shell transversely sub-triangular, minutely and concentrically wrinkled; buccal margin rather, shorter than ventral; basal margin nearly rectilinear from behind the middle to the anterior termination.

Plate XXII. Fig. 6, Interior and exterior of fossil shell, natural size.

Locality. Waccamaw.

Museum, College of. Charleston.

The genus Teluina commenced its existence in the ocean of the Cretaceous period, is found in the Tertiary, and is still an inhabitant of the seas of temperate and warm climates.

\section{PSAMMOCOLA.-BLAIN.}

The genus Psammocola commenced its existence in the seas of the Cretaceous period.

$$
\text { PSAM MOCOLA PLEIOCEN } \dot{A} \text {. - (New Species.) }
$$

Plate XXII. Fig. 8.

P. testa oblongata, inequilaterali, convexa, striata, radiatim costata, costis multis, juxta umbones simplicibus, ad margines sulcatis vel complanatis; striis numerosis et incrementi lineis irregularibus concentricis lamellosisque, interruptis; margine buccali obtuse rotundata; margine anali sub-angulata, sub-compressa; umbonibus incurvis, approximatis.

Description. Shell oblong, inequilateral, convex, striate, radiately ribbed; ribs numerous, near the umbones simple and distinct, but towards the margins channelled or flattened; striæ numerous, interrupted with irregular concentric laminated lines of 
growth; buccal margin obtusely rounded; anal margin more angular and somewhat compressed; umbones incurved, approximating.

This shell resembles somewhat the Psammocola regia of Lea, found in the Meiocene of Virginia; but is readily distinguished by its inequilateral form and less prominent umbones.

As it is common in the Pleiocene of South-Carolina, we have named it after that formation.

Plate XXII. Fig. 8, Natural size.

Locality. Pee Dee; Waccamaw; Black River.

Museum, College of Charleston.

\section{LAVIGNON.-CUVIER.}

The genus Lavignon commenced its existence in the Cretaceous period.

L $A V$ I G NON TELLINOIDES. - D’ं Rв.

Plate XXIII. Fig. 1.

Mactra tellinoides, Con., Jour. Acad. Nat. Sci., Vol. 6, p. 258, pl. 11, figs. $2,3$.

Cumingia tellinoides, Con., Foss. Ter. For., p. 28, pl. 15, fig. 4.

Lavignon tellinoides, d'Orb., Prod. de Paléontologie, Vol. 3, p, 101, No. 1891.

L. testa ovata, tenui, fragili, striata; striis elevatis, concentricis, extremitate altera rotundata, altera leviter compressa, sub-acuta, dente laterali in una valva obsoleto.

Description. Shell ovate, thin, fragile, with numerous raised concentric striæ; one end regularly rounded, the other slightly compressed and somewhat pointed at the extremity; lateral teeth distinct in one valve, in the other obsolete.

Conrad says this shell inhabits the Northern Atlantic coast of the United States.

Plate XXIII. Fig. 1, Interior and exterior of shell, natural size.

Locality. Pee Dee.

Museum, College of Charleston. 


\section{SINODESMIA.-RECLUS.}

The genus Sinodesnia commenced its existence in the Meiocene seas.

$$
\text { SINODESMIA CARI N A T A. - D'O в в. }
$$

Plate XXIII. Fig. 2.

Amphidesma carinata, Con., Foss. Ter. For., p. 37, pl. 19, fig. 7.

Amphidesma carinata, Con., Jour. Acad. Nat. Sci., Vol. 6, p. 229, pl. 9, fig. 23.

Sinodesmia carinata, d’ Orb., Prod. de Paléontologie, Vol. 3, p. 101, No. 1890.

S. testa ovali compressa, striis temuissimis confertis, et sulcis profundioribus remotisque impressa; umbonibus post medium positis; margine obtuse undulata.

Description. Shell ovate-oval, compressed, with regular concentric striæ fine and crowded and others more profound and remote; beaks rather posterior to the middle, slightly prominent; submargin with an obtuse undulation.

Plate XXIII. Fig. 2, Natural size.

Locality. Waccamaw. Museum, College of Charleston.

\section{AMPHIDESMA.-LAM.}

The genus Amphidesin commenced its existence in the seas of the Meiocene period.

$$
\text { A M PHIDESMA EQUALIS.-CON. }
$$

\section{Phate XXIII. FIG. 3.}

Amphidesma equalis, Con., Jour. Acad. Nat. Sci., Vol. 2, p. 308. 7, , 1 2 2-2 Amphidesma equalis, Con., Foss. Ter. For., p. 76, pl. 43, fig. 9.

Amphidesma equalis, Say, Amn. Conch., p. 28.

Amphidesma equalis, d' Orb., Prod. de Paléontologie, Vol. 3, p. 101, No. 1886.

A. testa sub-orbiculari, ventricosa, lavi; umbonibus extremitatem analem propioribus; declivitate umbonali, submarginali, subcarinata; latere anali leviter inflexo. 
Description. Shell sub-orbicular, ventricose, smooth; beaks sub-medial nearest to anal end; umbonial slope sub-marginal, slightly carinated; anal side somewhat warped or bent.

This is a common recent species on the shores of South-Carolina, Florida, and Alabama, and fossil in the Post Pleiocene of this State.

Plate XXIII. Fig. 3, Exterior of valve, natural size.

LocaLity. Smith's, Goose Creek; Waccamaw.

Museum, College of Charleston.

A M P IIIDESM A ORB I UULATA.-SAY.

Plate XXIII. Fig. 4.

Amphidesma orbiculata, Say, Jour. Acad. Nat. Sci., Vol. 2, p. 307.

A. testa orbiculari, sub-compressa, lineis concentricis tenuiter striata; his a laminis elevatis concentricis irregulariter interruptis; margine buccali obtuse undulata; fovea ligamentali profunda, fusiformi, usque ad umbonis apicem excavata.

Description. Shell orbicular, sub-compressed; surface finely marked with concentric lines of growth, which are interrupted irregularly with raised sub-laminated concentric lines; buccal margin obtusely undulated; interior ligamental cavity profound, fusiform, parrallel with marginal slope, and extending from tip of beak.

In young shells, longitudinal, radiating, and obsolete lines are distinctly seen intersecting the lines of growth, but in older specimens a few lines only are visible upon the buccal folds or undulations.

This species is abundantly fossil in the Post Pleiocene, and is recent on the coast of the State.

Plate XXIII. Fig. 4, Interior and exterior of shell.

Locality. Waccamaw.

Museum, College of Charleston. 
A M P H I E S A E Q U A T A. - CON.

Plate XXIII. Fig. 5.

Amphidesma æquata, Con., Proceed. Acad. Nat. Sci., Vol. 1, p. 307.

Amphidesma æquata, Con., Foss. Ter. For., p. 65, pl. 36, fig. 5.

Amphidesma æquata, d’ Orb., Prod. de Paléontologie, Vol. 3, p. 101, No. 1887.

A. testa in longitudinem ovali, convexa, striis 17 lamellosis concentricisque instructa; umbonibus sub-prominentibus.

Description. Shell longitudinally oval, convex, with about 17 laminated concentric striæ; buccal and anal margins nearly equally rounded; pallial margin regularly rounded; beaks slightly prominent.

This species is rare in the Pleiocene of South-Carolina; the numerous laminated concentric striæ are very characteristic.

Plate XXIII. Fig. 5, Imperfect shell, natural size.

Locality. Pee Dee.

Museum, College of Charleston.

\section{DONAX.-LINN.}

The genus Donax commenced its existence in the seas of the Eocene period.

$$
\text { DONAX VARIABILIS.-SAY. }
$$

Plate XXIII. Fig. 6.

Donax variabilis, Say, Jour. Acad. Nat. Sci., Vol. 2, p. 305.

D. testa triangulari, striis inconspicuis, longitudinalibus, parallelis, equalibus, impressis; margine buccali oblique truncata, cordata, sutura sub-convexa; margine anali sublineari, sutura dentata; margine palliali media paulo prominente, intus crenulata. 
Description. Shell triangular; longitudinally striated, with equal, parallel, regular impressed, but indistinct lines; buccal margin obliquely truncated, cordate, suture subconvex; anal margin nearly rectilinear, suture indented; pallial margin a little prominent, beyond a regular curve, near the middle; interior edge crenate.

This is an abundant recent species upon the sea shores of the South, and is found also fossil in great quantities in the Post Pleiocene beds. We have only an insignificant specimen to figure, but many casts are to be seen in the marl of Goose Creek.

Plate XXIII. Fig. 6, Fossil, natural size.

Locality. Sumter District; Smith's, Goose Creek.

Museum, College of Charleston.

\section{MACTRA.-LAM.}

The genus Mactra commenced its existence in the seas of the Jurassic period.

$$
\text { MAOTRA OBLONGATA.-SAY. }
$$

Plate XXili, Hig. 7.

Mactra oblongata, Say, Jour. Acad. Nat. Sci., Vol. 2, p. 310.

M. testa transversa oblongo-ovali, leviter rugata; plicis duabis ad marginem buccalem ab apice radiantibus.

Description. Shell transverse oblong-oval, very slightly wrinkled; buccal margin with two distinct lines or folds extending from apex.

The specimen from which our figure is •taken was found in the marl beds of the Pee Dee, and compared with recent shells of the same species so abundant on the sea shore of Waccamaw, is remarkably large. At first we were disposed to consider it a distinct species, but upon careful examination and comparison can discover no difference whatever, except size.

Plate XXIII. Fig. 7, Natural size.

Locality. Pee Dee

Muscum, College of Charleston. 


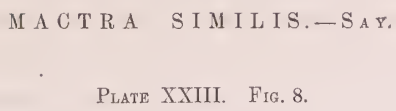

Mactra similis, Say, Jour. Acad. Nat. Sci., Vol. 2, p. 309.

M. testa oblongo-ovali aquilaterali, tenuissime et concentrice striata; lineis elevatis sublaminatis concentricis duabus vel tribus; umbonibus centralibus.

Description. Shell oblong-oval equilateral, surface finely marked with concentric lines of growth, which are almost obsolete, and always interrupted irregularly with two or three raised sub-laminated concentric lines; buccal and anal margins nearly equally rounded, the anal a little more pointed in some specimens; beaks central.

This is a very abundant living species on the Southern coast, and somewhat resembles in outline M. oblongaty, but is easily distinguished, as the folds on the buccal end are wanting; it is also a thicker shell than M. овLONGata.

\section{Plate XXIII. Fig. 8, Natural size.}

Localtity. Black River; Smith's, Goose Creek.

Museum, College of Charleston.

M A C TRA LA TERA L I S. - SAY.

Plate XXIII. Fig. 9.

Mactra lateralis, Say, Jour. Acad. Nat. Sci., Vol. 2, p. 309.

Mactra lateralis, Con., Amn. Mar. Conch., p. 62, pl. 14, fig. 2

M. testa parva, sub-triangulari lavi vel interdum tenuiter striata, sub-cquilaterali; margine buccali rotundata; margine anali elongata, acuta; regione buccali plana, cordata.

Description. Shell small, sub-triangular, smooth, or finely marked by the lines of growth, sub-equilateral; buccal margin rounded; anal margin prolonged, pointed; buccal region flat, heart shaped. 
Like M. smimis, this species is found recent on the Southern coast. Numerous specimens can at almost all times be collected from the sea beaches.

PLate XXIII. Fig. 9, Interior and exterior of fossil, natural size.

Locality. Pee Dee; Waccamaw; Smith's, Goose Creek.

Museum, College of Charleston.

MACTRA CONGESTA.-CON.

Plate XXIII. Fig. 10.

Mactra congesta, Con., Foss. Ter. For., p. 27, pl. 15, fig. 2.

Mactra congesta, Con., Silliman's Amer. Jour., Vol. 23, p. 340.

M. testa triangulari, ventricosa, inequilaterali; rostris prominentibus, umbonibus magnis; margine buccali rotundata; margine anali coarctata, acuta.

Description. Shell triangular, ventricose, inequilateral; beaks prominent; umbones large; buccal margin rounded; anal margin narrowed, pointed.

This species greatly resembles M. Lateralis, Say; but is thicker, more inflated, and attains a greater size, commonly twice as large. It is a common species in the Meiocene of Virginia.

Plate XXIII. Fig. 10, Both valves, natural size.

Locality. Pee Dee; Smith's, Goose Greek.

Museum, College of Charleston. 


\section{GNATHODON.-Gray.}

The genus Gnathodon commenced its existence in the seas of the Meiocene period.

$$
\text { G N A THODON GRA Y II. - CON. }
$$

Plate XXIII. Fig. 11.

Gnathodon Grayii, Con., Foss. Ter. For., p. 23, pl. 13, fig. 1.

Gnathodon minor, Con., Silliman's Jour., Vol. 42, pl. 2, fig. 14.

Gnathodon minor, Con., Foss. Ter. For., p. 69, pl. 39, fig 6.

G. testa subtriangulari, ventricosa, incquilaterali; margine buccali obtuse rotundata; margine anali angulari, cuneiformi; umbonibus valde prominentibus.

Description. Shell sub-triangular ventricose, inequilateral; buccal margin obtusely rounded; anal margin angular, cuneiform; umbones produced, prominent.

Grathodon minor we consider the young of G. Grayis, and have therefore placed it as a synonym. This is an abundant species in the Post Pleiocene beds of South-Carolina, and is found fossil near Wilmington, N. C. Though not living on the Atlantic shores of the Southern coast, it abounds in the bays of the Northern coast of the gulf of Mexico.

Plate XXIII. Fig. 11, Natural size.

LocALITY. Waccamaw. Museum, College of Charleston.

\section{SOLECURTUS.-BLAIN.}

SOLECURTUS CARIBCES. - BLAIN.

Plate XXIII. Figs. 12 and 13

Solecurtus caribœus, Blain, Dict. des Sciences Naturelle, Vol. 29, p. 240.

Solecurtus caribœus, Con., Marine Conch., p. 22, pl. 4, fig. 3.

Solecurtus caribœus, Gould., Invert. Mass., p, 30.

S. testa oblongo-ovali, recta, utrinque hiante; margine buccali et anali obtuse rotundatis; margine palliali recta, leviter in medio compressa; umbonibus sub-centralibus, prominulis. 
Description. Shell oblong-oval, straight, gaping at ends; buceal and anal margins obtusely rounded; pallial margin straight, slightly compressed near the middle; beaks nearly central, slightly elevated.

In the Post Pleiocene beds of South-Carolina, this species is found in great numbers, and is recent along the Southern coast.

Plate XXIII. Fig. 12, Exterior of shell.

“ 13, Interior of shell, natural size.

Locality. Pee Dee; Waccamaw; Smith's, Goose Creek.

Museum, College of Charleston.

The genus Solecurtus commenced its existence in the seas of the Néocomien or early Cretaceous period.

\section{PANOPEA.-SAY.}

The genus Panopar commenced its existence in the seas of the Triassic period.

PA NOPEA REFLEXA.-SAY.

Plate XXIV. Fig. 1.

Panopœa reflexa, Say, Jour. Acad. Nat. Sci., Vol. 4, p. 153, pl. 13, fig. 4.

Panopœa reflexa, Con., Foss. Med. Ter. For., p. 5, pl. 3, fig. 4.

Mya reflexa, Lea, Jour. Acad. Nat. Sci., Vol. 4, p. 153, pl. 13, fig. 4.

P. testa oblongo-subovali, corrugata; margine buccali late et obtuse rotundata; margine anali reflexa, angustiori, et longiori.

Description. Shell oblong-subovate, wrinkled; anal margin reflected, narrower and longer than the buccal, which is widely and obtusely rounded.

Plate XXIV. Fig. 1, Natural size.

Locality. Pee Dee.

Museum, College of Charleston. 


\section{PHOLADOMYA.-SowERBY.}

The genus Pholadonya commenced its existence in the seas of the Liassic period.

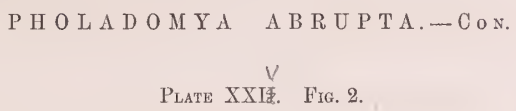

Pholadomya abrupta, Con., Foss. Med. Ter. For., p. 3, pl. 1, fig. 4.

P. testa oblongo-ovali, compressa, concentrice rugosa, costis irregularibus quatuor vel quinque apice divergentibus; margine buccali rotundata crassa; margine anali truncata reflexa, tenui.

Description. Shell oblong-oval, compressed, concentrically rugose, with four or five irregular ridges or ribs diverging from the apex; buccal margin rounded, thick; anal margin truncated, reflected, thin.

Plate XXIV. Fig. 2, Natural size.

Locality. Sumter District; Smith's, Goose Creek.

Museum, College of Charleston.

SOLEN.-LINN.

SOLEN ENSIS.-LINN.

Peate XXIV. Fig. 3.

Solen ensis, Linn., Syst. Nat., 1114.

Solen ensis, Lam., An. sans. Vert., Vol. 6, p. 55.

Solen ensis, Con., Marine Conch., pl. 5, fig. 1.

Solen curvus, Lister, Conch. t. 411, fo. 257.

Solen ensis, Gould, Invert. Mass., p. 28.

S. testa ensiformi; margine dorsali et palliali parallelis; margine buccali et anali subtruncatis. 
Description. Shell sword-shaped; dorsal and pallial margins parallel; buccal and anal margins sub-truncate.

This is a well-known shell, living all along the coast of the United States.

Plate XXIV. Fig. 3, Natural size.

Locality. Pee Dee; Smith's, Goose Creek.

Museum, College of Charleston.

The genus SolEn commenced its existence during the Cretaceous period.

\section{PHOLAS.-LINN.}

The genus Prolas commenced its existence in the seas of the Cretaceous period.

$$
\begin{aligned}
& \text { PHOLAS OOSTATA.- ERH = areunta Conr. } \\
& \text { T aeuminata com }
\end{aligned}
$$

Pholas costata, Linn, Syst. Nat., 1111.

Pholas costata, Lister, Conch., pl. 434.

Pholas costata, Gualt, Test. t. 105, f. G.

Pholas costata, Chemn., Conch. VIII. t. 101, f. 863.

Pholas costata, Brug., Ency. Meth., pl. 169, figs. 1 and 2.

Pholas costata, Św., Genera No. 23, pl. 1.

Pholas costata, Lam., An. sans. Vert., VI., 45.

Pholas costata, Wood, Gen. Conch., pl. 15, figs. 1 and 2.

Pholas costata, Gould, Invert. of Mass., p. 26.

P. testa magna, temui, oblongo-ovata; margine buccali rotundata; margine anali acutiori; margine dorsali supra umbones reflexa; costis radiantibus regulariter dentatis.

Description. Shell large, thin, oblong-ovate; buccal margin rounded, anal margin more pointed; dorsal margin reflected over the umbones; ribs radiating, with coarse lines of growth, producing tooth-like elevations at regular intervals on each rib. 
This is the most common of the three species of PhoLAdrde on the Southern coast, and is abundant in the harbors of this State. It often attains the width of six inches. Our figure is taken from a small specimen.

Plate XXIV. FIg. 4, Fossil, natural size.

Locality. Waccamaw.

Museum, College of Charleston.

PHOLAS OBLONGATA.-SAX. parducia can-

Plate XXIV. Fig. 5.

Pholas oblongata, Say, Jour. Acad. Nat. Sci., Vol. 2, p. 320.

P. oblongo-ovata, inflata, transverse et longitudinaliter striata; striis muricatis antice elevatioribus; margine buccali acute rotundata; margine anali compressa; margine dorsali antice reflexa, cavum conficiente; cardine callosa; minute bifariam striata, cellulis circiter duodecim.

Description. Shell oblong-ovate, inflated, transversely and longitudinally striated; striæ muricated, and elevated on the buccal side into ribs; buccal margin acutely rounded; anal margin compressed; dorsal margin anteriorly reflexed, forming a cavity; hinge callous, minutely striated transversely ard longitudinally, and with about twelve cells.

This shell is easily distinguished from P. costata by the hinge-cells. It is living on the coast of South-Carolina, Georgia, and Florida, and is quite common.

Plate XXIV. Fig. 5, Natural size.

Locality. Waccamaw; Pee Dee; Sumter.

Museum, College of Charleston. 
PHOLAS MEM II N GERI.-(New Species.)

Plate XXIV. Fig, 6.

P. testa oblongo-ovata, cylindrica, inflata, lineis elevatis, distantihus, laminatis, subdentatis instructa; costis 6-8 ab apice ad marginem pallialem divergentibus; costis anticis posticisque obsoletis; margine anali tenui subtruncata, hiante; margine buccali crassa, laminata, acuta.

Description. Shell oblong-ovate, cylindric, inflated; surface lines of growth irregularly concentric, widely separated, coarsely laminated anteriorly; laminæ with raised and free edges, having a few elevated knobs or teeth, reflexed or folded on the anterior dorsal margin, giving the shell an acute point on the buccal margin, and forming a laminated umbonial shield, which extends from near the point to beyond the beak posteriorly and is reflected upon the umbones, the inferior surface of the upper plate divided by a few indistinct almost obsolete transverse septa, which in some individuals are profoundly obsolete; six or eight radiating ribs extend from the beak to the pallial margin, but they become also profoundly obsolete towards the buccal and anal margins; anal margin thin, sub-truncated gaping, its surface lines wrinkled and indistinct; buccal margin thick, laminated, acutely pointed.

This species may be easily distinguished from its congeners by its greater length from beak to pallial margin, its laminated umbonial plates with small indistinct transverse septa, and its raised laminated lines of growth having a few angulated knobs or teeth which are destitute of arches; moreover, the buccal margin is thick and acutely pointed.

By inscribing this fossil to the Hon. C. G. Memminger, the distinguished jurist, statesman, and liberal patron of education, science and art, we take pleasure in connecting his name with the rocks of his native State.

Plate XXIV. Fig. 6, Left valve, natural size. The small transverse septa between the superior umbonial plates are too indistinct to be given in the figure.

Locality. Sumter District.

Museum, College of Charleston. 
G A S T E R OPODA.

DENTALIADE.

DENTALIUM.-LIN.

DEN TALIUM ATTENUATUM,-SAY.

Plate XXV. Fig. 1.

Dentalium attenuatum, Say, Jour. Acad. Nat. Sci., Vol. 4, p. 154.

- D. testa leviter curvata, conica, costata; costis quindecim, prominulis teretibusque, ad basim attenuatis; incrementi lineis multis, indistinctis; apertura rotunda.

Description. Shell slightly curved, tapering, costate; costæ 15, distinct and rounded, less prominent towards the base, intervening grooves simple; lines of growth numerous but indistinct; aperture orbicular.

Say described this species from a Meiocene fossil of Maryland. D. Dentale, Conrad, we infer is a Virginia fossil, though he does not give the locality. The South-Carolina specimen agrees with Say's description. Dr. Gould makes D. atTenuatum a synonym of D. Dentale, Linn, which is a recent shell from the coast of Massachusetts.

Plate XXV. Fig. 1, Fossil, natural size.

Locality. Pee Dee.

Museum, College of Charleston.

DE TALIU M P L E I O E N U M.- (New Species.)

Plate XXV. Fig. 2.

D. testa modice incurvata, costis duodequadraginta, indistinctis obtecta; incrementi lineis multis parum distinctis; apertura rotunda. 
Description. Shell slightly curved, marked with about thirty-eight very indistinct ribs which become profoundly obsolete towards the base; lines of growth numerous, indistinct; aperture orbicular.

This species may be readily distinguished by its numerous ribs or striæ, which are barely visible to the naked eye, but with a lens are very distinct.

Plate XXV. Fig. 2, Fossil, natural size; apex broken.

Locality. Pee Dee.

Museum, College of Charleston.

\author{
DE N TALIUM THALL US. - Cos. \\ Plate XXV. Fig. 3.
}

Dentalium thallus, Con., Jour. Acad. Nat. Sci., Vol. 7, p. I42.

Dentalium thallus, Con., Foss. Med. Ter., p. 78, pl. 44, fig. 5 .

D. testa modice curvata, lavi, perpolita, inframedium tumida, versus basim paullatim coarctata; apertura ovali.

Description. Shell slightly curved, smooth, highly polished, tumid below the middle and gradually contracting towards the base; aperture oval.

Common in the Meiocene of Virginia and the Pleiocene of North and South Carolina.

Plate XXV. Fig. 3, Fossil, natural size.

Locality. Pee Dee.

Museum, College of Charleston.

The genus Dentalium commenced its existence in the seas of the Devonian period. 


\section{CALYPTR EIDE.}

\section{CRUCIBULUM.-Schum. (1817.)}

DISPOT AEA.-SAY. 1824.

ORUCIBULUM MULTILINEATA.-COX.

Plate XXV. Fig. 7.

Dispotæa multilineata, Con., Sill. Amn. Jour. Sci., Vol. 41, p. 346, pl. 2, fig. 8.

Dispotæa multilineata, Con., Foss. Med. Ter. Form., p. 80.

Crucibulum multilineata, Con., Pro. Acad. Nat. Sci., Vol. 7, p. 30.

C. testa depressa, tenui, apice sub-centrali, elevata; orbi hinc lineis squamosis illinc lineis tenuibus ramosis obtecta; septo angustato, margine soluto.

Description. Shell depressed, very thin; apex sub-central elevated; one side of disk with squamose lines, the opposite with fine ramose lines, without scales; diaphragm contracted, margin discontinuous, and acutely angled on the inner side.

Plate XXV. Figs. 7, Exterior and interior of shell, natural size.

Locality. Pee Dee. Museum, College of Charleston.

CRUCIBULUM COSTATA.-CON.

Plate XXV. Fig. 4.

Calyptræa costata, Say, Silliman's Amn. Jour., Vol. 2, p. 40.

Dispotæa costata, Con., Foss. Med. Ter., p. 79, pl. 45, fig. 2.

Dispotæa costata, Say, Jour. Acad. Nat. Sci., Vol. 4, p. 132.

Calyptræa pileolus, H. C. Lea, Proceed. Philos. Soc., Vol. 9, pl. 35, fig. 38.

Crucibulum costata, Con., Proceed. Ac. Nat. Sci., Vol. 7, p. 30.

C. tèsta sub-orbiculari, conica, costis irregularibus concentrice crasseque rugosis instructa; 
margine orbiculato, dentato, apice subcentrali, prominenti; septo subovali, profundo, marginibus solutis.

Description: Shell sub-orbicular conical, with irregular ribs, having course, concentric wrinkles, which give the margins a profound scollop; margins circular, apex, subcentral, prominent; diaphragm sub-oval, profound, with free margins.

This species varies much in character, especially the young shells, which sometimes have obsolete ribs. It is common in the Meiocene of Virginia and Maryland, and found abundantly in the Pleiocene of this State.

Plate XXV. Figs. 4, Interior and exterior of shell, natural size.

Locality.' Pee Dee; Goose Creek. Museum, College of Charleston.

CRUCIBULU H RA MOSA.-CON.

Plate XXV. Fig. 5.

Dispotæa ramosa, Con., Jour. Acad. Nat. Sci., Vol. 8, p. 187.

Dispotæa ramosa, Con., Foss. Med. Ter., p. 79, pl. 45, fig. 3.

Crucibulum ramosa, Con., Pro. Acad. Nat. Sci., Vol. 7, p. 30.

C. testa subovali, elevata; costis prominentibus planulatis lineis ramosis ornatis; apice ad latus inclinata; septo ovato, integro.

Description. Shell sub-oval, elevated; ribs prominent, somewhat flattened, and beautifully ornamented with ramose lines; apex inclined laterally; diaphragm ovate, entire.

C. ramosa, like its congener, C. costata, is common to the Meiocene of Virginia, and the Pleiocene of South Carolina.

Plate XXV. Figs. 5, Exterior and interior of shell, natural size.

Locality. Pee Dee; Goose Creek.

Museum, College of Charleston. 


\section{R U C I B U L U M D U O S A. - CON.}

Plate XXV. Fig. 6.

Dispotæa dumosa, Con., Sill. Amn. Jour. Sci., Vol. 41, p. 346, pl. 2, fig. 9.

Dispotæa dumosa, Con., Foss. Med. Ter., p. 80.

Crucibulum dumosa, Con., Pro. Ac. Nat. Sci., Vol. 7, p. 30.

C. testa elevata; costis obsoletis, spinis tubulosis armatis; apice in spira minuta contorta, ad latus inclinata; septo ad margines soluto, deflecto.

Description. Shell elevated; ribs obsolete, with erect tubular spines; apex minutely spiral and inclined to one side; diaphragm widely discontinuous on the margin, which is bent on the inner side.

The spinous, obsolete ribs are quite characteristic of this small, but pretty species.

Plate XXV. Figs. 6, Exterior and interior of shell, natural size.

Locality. Pee Dee

Museum, College of Charleston.

\section{TROCHITA._-Sсншм. (1817.)}

\section{N F U N D I B U L U M. - D'OR B. (1 $8 \begin{array}{lll}8 & 4 & 6 .)\end{array}$}

TR OCHITA CENTRALIS.

-Plate XXV. Fig. 8.

Infundibulum centralis, Con., Sill. Am. Jour. Sci., Vol. 41, p. 348.

Infundibulum centralis, Con., Foss. Med. Ter. Form., p. 80, pl. 45, fig. 5.

T. testa ovata, tumida, lavi vel transverse rugosa; apice mediali, in spira minuta contorta, prominenti, acuta. 
Description. Shell ovate, tumid, smooth, or with transverse wrinkles; apex medial, minutely spiral, prominent, acute.

Found also in the Meiocene of Maryland, and is now living upon the coast of this State.

Plate XXV. Figs. 8, Exterior and interior of shell, natural size.

Locality. Pee Dee.

Museum, College of Charleston.

\section{CRYPTA.—HUnPH. (1797.)}

C R E P I U LA.- LA I. (1 801 .)

CRYPTA FOR NICATA.

Plate XXV. Fig. 9.

Crepidula fornicata, Lam., An. sans Vert. Vol. 7, p. 641.

Crepidula fornicata, Martini, 1, pl. 13, figs. 129, 130.

Crepidula fornicata, Say, Jour. Acad. Nat. Sci., Vol. 2, p. 225.

Crepidula fornicata, Con., Foss. Med. Ter. Form., pl. 45, fig. 10.

C. testa obliquo-ovali, convexi, lavi, interdum corrugata obliteratis undatim longitudinalibus lineis; apice prominenti versus latus contorto, margine annexo; septo subconcavo, margine soluto undanto.

Description. Shell oblique-oval, convex, smooth, sometimes wrinkled with obsolete undulating longitudinal lines; apex prominent, turned to one side and united with the margin; diaphragm sub-concave, occupying half the interior of shell, the free edge waving.

This is a common species in the Pleiocene beds of South-Carolina, and abundant on the sea-shores in a living state. In the marl of Goose Creek a series of united casts occupying their natural position, are common fossils.

Plate XXV. Fig. 9, Exterior of fossil, natural size.

Locality. Pee Dee.

Museum, College of Charleston. 


\section{R Y P TA S PI NOSA.}

Plate XXY. Fig. 10.

Crepidula spinosa, Con., Proceed. Acad. Nat. Sci., Vol. 1, p. 307.

C. testa ovali, convexa, costata; costis cum irregularibus arcuatis spinis; septo subconcavo; margine soluto sinuoso.

Description. Shell oval, convex, costate; costæ with irregular arched spines, formed by the rugose lines of growth; diaphragm sub-concave, occupying one half of interior of shell, free edge sinuous.

We refer this shell, with some doubt, to C. spinosa, Conrad, though it resembles C. ACULEATA, a recent species of the coast, but much larger than any specimen we have met with.

Plate XXV. Fig. 10, Natural size.

Locality. Pee Dee. Museum, College of Charleston.

CRYPTA PLANA.

Plate XXV, Fig. 12.

Crepidula plana, Say, Jour. Ac. Nat. Sci., Vol. 2, p. 226.

Crepidula plana, Say, Amn. Conch., pl. 44.

Crepidula plana, Gould, Invert. Mass., p. 159, fig. 16.

Crepidula plana, d’Orbigny, Prodrome de Paléontologie, Vol. 3, p. 177, No. 248.

C. testa oblongo-ovali, superficie plana aut convexa; longitudinalibus rugis; apice nonprominente angulari; septo convexo.

Description. Shell oblong-oval, surface flat or convex, wrinkled longitudinally; apex not prominent, but angular, sometimes obsolete; diaphragm convex. 
By some this is considered only a variety of C. ForNICATA; like this species it is common in the Pleiocene, and also in the recent state upon the sea-shores of South Carolina.

Plate XXV. Fig. 12, Exterior of shell, natural size.

Locality. Pee Dee.

Museum, College of Charleston.

CRYPTA COSTATA.

Plate XXV. Fig. 11.

Crepidula costata, Morton, Jour. Acad. Nat Sci., Vol. 6, p. 115, pl. 7, figs. 2 and 3.

C. testa crassa, ovali, perconvexa; dorso costis numerosis, elevatis, longitudinalibus obtecto; latere sinistro planulato; margine plano.

Description. Shell oval, thick, very convex, with numerous longitudinal elevated costæ; beaked side flattened; margin plain.-S. G. Morton.

Dr. Morton described this shell as above, from a specimen found in the "upper Marine formation of Maryland," and it corresponds with our Carolina shell.

Plate XXV. Fig. 11.

Locality. Darlington.

Museum, College of Charleston.

\section{HIPPONIX.-DEFRANCE.}

H I P P O N I B ULLII. - (New, Species.)

Plate XXV. Fig. 13.

H. testa tenui, obliquo-conica, carinata; apice sub-acuto; lineis. irregularibus; apertura sub-ovali a tergo angulata; margine temui. 
Description. Shell thin, obliquely-conical, carinated; apex sub-acute; lines of growth irregular, waved; aperture sub-oval, angulated behind, margin thin.

This is the first of the genus yet found in the Tertiary of the United States; the carina or reflexed keel, which extends from the apex to the basal margin, is sufficiently characteristic of this rare species.

Presented to us by the Hon. W. I. Bull, of St. Andrews, whose name we attach to it.

Plate XXV. Fig. 13, Side view of fossil, to show the carina.

" $13 a$, Outline of the aperture.

Locality. Pee Dee.

Museum, College of Charleston.

\section{FISSURELLID $\mathbb{E}$.}

F IS S U R L L A.- LA M.

FIS SURELLA REDIMICULA.-SAT.

Plate XXV. Fig. 14.

Fissurella redimicula, Say, Jour. Acad. Nat. Sci., Vol. 4, p. 132, pl. 8. fig. 1.

T. testa ovato-ovali, oblonga, aliquanto elevata, crassa, costata; costis longitudinalibuis alternantibus, approximantibus; apertura inclinata, subtruncata.

Description. Shell ovate-oval, oblong, somewhat elevated, thick, costate; costæ longitudinal, alternate, approximate; aperture inclined, subtruncated.

This is the only species of Fissurella we have found in the Pleiocene of this State; it is common to the Meiocene of Maryland and Virginia, and became extinct at the close of the Pleiocene period.

Plate XXV. Fig. 14, Shell natural size, viewed from above.

Locality. Pee Dee; Smith's, Goose Creek.

Museum, College of Charleston. 


\section{NATICICID $\mathbb{2}$.}

\section{N A T I C A. - L A M.}

\section{NATICA HEROS. - SAY.}

Plate XXV. Fig. 15.

Natica heros, Say, Jour. Acad. Nat. Sci., Vol. 2, p. 248.

Natica heros, Gould, Invert Mass., p. 231, fig. 160.

N. testa sub-globosa; anfractibus convexis interdum aquatis; sutura bene signata; apertura ovata; umbilico magno, simplici.

Description. Shell sub-globose; whorls convex sometimes flattened, and with distinct lines of growth; suture well marked; aperture ovate; umbilicus large, simple.

This shell is often found in a recent state on the coast of New Jersey, but more abundantly north of Cape Cod; it is a rare species in the Pleiocene of South Carolina, and but seldom found on the coast south of Hatteras, in a living state.

Plate XXV. FIg. 15, Front and back view of shell, natural size.

Locality. Pee Dee; Smith's, Goose Creek.

Museum, College of Charleston.

\section{NATICA DUPLICATA.-SAY.}

Plate XXV. Fig 16.

Natica duplicata, Say, Jour. Acad. Nat. Sci., Vol. 2, p. 247.

Natica duplicata, Gould, Invert. Mass, p. 236, fig. 163.

N. testa solida conico-ovata; umbilico irregulari, profunde sulcato, partim vel omnino callo obtecto; apertura ovata, obliqua. 
Description. Shell solid, conical-ovate; umbilicus irregular, deeply grooved, and partially or entirely covered with a callus; aperture ovate, oblique.

This is an abundant species, but variable in shape; in some specimens the spire is more elevated than in others. In a recent state it is common along the Atlantic shores of the United States, south of Nantucket.

Plate XXV. Fig. 16. Natural size.

Locality. Pee Dee; Goose Creek. Museum, College of Charleston.

\section{NATICA CARENA.-LAM.}

Plate XXV. Figs. 17 and $17 a$.

Nerita canrena, Linn, Syst. Nat., p. 1251.

Natica canrena, Lamk, Anim. sans Vert., Vol. 8, p. 633.

N. testa crassa; spira striis valde impressa; umbilico gibboso; columna parvo callo.

Description. Shell thick, lines of growth on the spire deeply impressed, umbilicus gibbous, pillar with a small callus.

The deeply impressed lines of growth on the spire are quite characteristic of this species. $\mathrm{N}$. CANRENa is a rare shell in the recent state on the Carolina shores, but common on the coast of Florida and the West India Islands.

Plate XXV. Figs. 17 and $17 a$.

Locality. Pee Dee and Smith's, Goose Creek. 


\title{
NATICA CAROLINIANA.-CON.
}

Plate XXV. Fig. 18.

Natica Caroliniana, Con, Sill. Jour., Vol. 41, p. 347, pl. 2, fig. 18.

N. testa obliqua sub-ovali; lavi; umbilico rotundata, centrali, eminenti, crassa carina instructo; apiçe eminenti; apertura sub-ovali.

Description. Shell obliquely sub-oval, smooth; umbilicus with a central, rounded, prominent, thick carina; apex prominent, aperture sub-oval.

N. Caroliniana is found in the Pleiocene of North and South Carolina. We are not aw are of its existence in a recent state.

Plate XXV. Frg. 18, Natural size.

Locality. Darlington.

Museum, College of Charleston.

\section{TURBINIDE.}

\section{MONODONTA.-LAM.}

\author{
MONODONTA KIA WAHENSIS.- (New Species.)
}

Plate XXVI. Fig. 1.

M. testa conico-ovata, ventricosa; spira obtusa; anfractibus rotundatis, octo vel duodecim modice elevatis insuper planis striis spiratim instructis; umbilico profundo spira modo intorto; apertura integra rotunda; labro exteriori interne crenulato; labio uno dente instructo.

Description. Shell conical-ovate, ventricose; spire obtuse; whorls rounded, spirally striated, with eight to twelve slightly raised but flattened striæ, superior margin of whorls raised into a flattened ridge or carina which leans against the upper whorl partially cover- 
ing the suture; umbilicus deep, spiral; aperture entire circular; outer lip crenulated within; inner lip with one tooth.

But one specimen yet discovered in the Pleiocene, and from this our figure is taken; we found another on the sea-shore of Kiawah Island, that appears to be recent, though possibly it is a Post Pleiocene shell, from the sub-marine beds of the coast. We name it after Kiawah Island.

Plate XXVI. Fig. 1, Natural size.

Locality. Sumter.

Museum, College of Charleston.

TROCHUS.-LINN.

TROCHUS PHILANTROPUS.-OON.

Plate XXVI. Fig. 2.

Trochus philantropus, Con., Jour. Acad. Nat. Sci., Vol. 7. p. 157.

T. testa sub-conica; anfractibus prope basim sub-angulatis, lineis bene designatis granulatis spirce modoque intortis, alterna vice magnis et parvis, instructis; basi striis prope lavibus, non-crenulatis; sub-umbilicata; apertura oblique quadrangulari.

Description. Shell sub-conical, whorls slightly angular near their base, with prominent spiral beaded lines, alternating in size; striæ on the base nearly smooth, not crenulated; sub-umbilicated; aperture obliquely quadrangular._Con.

Our specimen only differs from the above description in having two beaded lines on the base near the umbilicus. We have as yet discovered only a single individual, but it is common in the Virginia Meiocene.

Plate XXVI. Fig. 2, Natural size.

Locality. Darlington District.

Museum, College of Charleston. 
TR OCH US A R M I L L A T US.-(New Species.)

Plate XXVI. Fig. 3.

T. testa depressa; anfractuum superficie una linea granulata, simpliciuumque spirce modo intortuum linearum quatuor paribus instructa; sutura canaliculata; peripheria sub-angulata tenuiter longitudinaliter striata; umbilico profundo, basalibus spirce modo intortis elevatis lineis circumdato, quarum duœ granulata unaque simplex, reliquœ numerosa tenuœque; apertura sub-quadrangulari.

Description. Shell depressed; surface of whorls with four pairs of simple revolving lines and one beaded line elevated below the suture extending from the apex to aperture; suture channeled; periphery sub-angulated, finely striated longitudinally; umbilicus profound, surrounded at the base with revolving raised lines, two of them beaded and one simple, the others numerous and fine; aperture sub-quadrangular.

This pretty species may be easily distinguished by its beaded spiral line which revolves below the suture from the apex to the aperture.

Plate XXVI. Fig. 3, Natural size.

Locality. Waccamaw.

Museum, College of Charleston.

T ROCHUS GE M II A.- (New Species.)

Plate XXVI. Fig. 4

T. testa parva, turrita; spira depressa; anfractibus angulatis, superiori superficie plana duabus elevatis cremulatis striis; striis superioribus pulchre crenulatis; striis mediis granulatis; basi convexa, striata; umbilico profundo, crenulato; aperture superiori basalique marginibus angulatis.

Description. Shell small, turrited; spire depressed; whorls angular, superior surface flat, with two raised crenulated striæ on each whorl, one at the angle and the other in the middle; superior striæ beautifully crenulated, middle striæ finely beaded; crenulations 
and beads formed by transverse grooves on the whorl, which extend from the suture to the periphery; periphery formed by a spiral raised line; base convex, striated; umbilicus profound, crenulated; superior and basal margin of aperture angular.

One of the most beautiful species of the genus; only a single specimen yet found.

Plate XXVI. Fig. 4, Natural size.

Locality. Pee Dee.

Museum, College of Charleston.

\section{LITORINIDE.}

\section{LITTORINA.-FERRUSS.}

LI T TORINA IRRORATA.-L. R. GiввE.

Plate XXVI. Fig. 5.

Turbo irrorata, Say, Jour. Acad. Nat. Sci., Vol. 2, p. 239.

Littorina irrorata, L. R. Gibbes, Cat. Fauna So. Ca., appendix Tuomey's Geology, p. 20.

L. testa crassa, turbinata; anfractibus lineis numerosis elevatis obtusis aqualibus spirce modo intortis; basali aufractu maximo; sutura bene designata; spira acuta; apertura magna integra rotundo-ovata; labri margine tenuato; labio crasso.

Description. Shell thick, top-shaped; whorls, with numerous revolving, elevated, obtuse, equal lines; body-whorl very large; suture well defined; spire acute; aperture large, entire, rounded-ovate; outer edge of lip thin; labium thick.

This is a very common estuary shell from New-Jersey to Florida. A thousand living specimens may at any time be collected, in a half-hour, from the mud-flats of Ashley river.

Plate XXVI. Fig. 5, Natural size. 


\title{
ARCHITECTONICA.-Bolten. (1798.)
}

SOLARIUM.-LAM. (1801.)

\section{A R C I TECTONICA PER P E T IVA.}

Plate XXVI. 'Fig. 6.

Trochus perspectivus, Linn, Syst. Nat., ed. 12, p. 1227.

Solarium perspectivum, Lam., Anim. sans Vert., Vol. 9, p. 97.

A. testa convexa; ad basim obtuse marginata; umbilico magno, pervio, pulchre crenulato.

Description. Shell convex, obtusely marginated at the base; umbilicus large, pervious and beautifully crenulated.

This is the description of Trochus perspectivus, Linn, an inhabitant of the Indian Ocean and China Seas. We can detect no specific difference in our fossil species.

Plate XXVI. Fig. 6, Natural size.

Locality. Marlborough. Museum, College of Charleston.

\author{
TEREBELLUM.-Browne. (1756.) \\ TURRITELLA.-LAM. (1801.)
}

T ER E B E L U M S T R I A T M. - (New Species.)

Plate XXVI. Fig. 7.

T. testa oblongata; apice acuto; connexis anfractibus multis spira modo intortis striis instructis, quarum media prominentissima; anfractibus magnis complanatis. 
Description. Shell elongated; apex acute; whorls convex with numerous revolving striæ, the middle one prominent, the large whorls flattened, those near the apex more convex; transverse wrinkles distinct only on the lower whorls.

It is easily distinguished from T. PLEBIA, of Conrad, by the fiattened whorls; it is also a larger shell, and not so profoundly turrited.

Plate XXVi. Fig. 7.

Locality. Darlington.

Museum, College of Charleston.

T E R E B E L U M E X A L T A T A.

Prate XXVI. Fig. 8.

Turritella exaltata, Con., Acad. Nat. Sci., Vol. 8, p. 188.

T. testa subulata, valde elongata, gradatim versus spiram attenuata; anfractibus convexis, spiratim striatis, sulcatis; sutura profunda.

Description. Shell subulate, profoundly elongated, very gradually tapering towards the spire; whorls convex, spirally striated, grooved near the base of each and with a raised rib on each side of the groove, the rib which margins the suture, is also delicately grooved; suture profound.

We have but two specimens of this shell, both of which are without the apex or spire; it must from its gradual tapering, attain a great length.

Plate XXVI. Fig. 8, Natural size.

Locality. Pee Dee.

Museum, College of Charleston. 


\section{T E R B E L L U M E T I W N ENSIS.-(New Species.) \\ Platé XXVI. Figs. 9 and 10.}

T. testa subulata, elongata; anfractibus striis duabus prominentibus spirce modo intortis ab suturibus equidistantibus, aliis mediis tenuis striis in anfractuum utroque impressis.

Description. Shell subulate, elongated; with two prominent spiral striæ equidistant from the sutures, and fine intermediate ones on each whorl.

This shell somewhat resembles T. alticostata, of Conrad, a Meiocene species from Maryland, and hitherto considered identical; but upon comparing a number of individuals from both localities, we satisfied ourselves they are specifically distinct. T. ALticostata is profoundly carinated near the base by a prominent spiral striæ or rib, the other striæ are comparatively quite small; the whorls are also compressed above.

\section{Plate XXVI. Fig. 9, Natural size. \\ "10, A young shell.}

Locality. Pee Dee; Goose Creek. Casts very abundant at latter locality.

Museum, College of Charleston.

TE R B E L L U M B U R D E I I. - (New Species.)

Plate XXV1. Fig. 11.

T. testa subulata, turrita; anfractibus complanatis, spiratim costatis, transverse undantibus striis; costis aut crenulatis aut granulatis.

Description. Shell subulate, turrited; whorls flattened; spirally ribbed, and transversely striated with waved striæ, which give the ribs a crenulated or beaded character.

We dedicate this species to our deceased friend and co-laborer, Dr. Thos. L. Burden.

Plate XXVI. Fig. 11, Natural size. The cremulations on the ribs are imperfectly figured in our drawing.

Locality. Pee Dee.

Museum, College of Charleston. 
VERMETUS.-A DANS. 1757.

VERMETUS A N G U I A.

Plate XXVi. Fig. 12.

Serpula anguina, H. C. Lea, Ter. fossil shells, p. 7, pl. 34, fig. 2.

S. testa contorta, adnexa, superficie sine lineis longitudinalibus; transversis striis; apertura rugosa, rotunda.

Description. Shell contorted, attached, without longitudinal lines on the surface, transversely striated; striæ rugose; aperture round.

Plate XXVI. Fig. 12. A cluster of individuals.

Locality. Pee Dee.

Museum, College of Charleston.

\section{PETALOCONCHUS.-LEA.}

PETALOCONCHUS SCULPTURATUS.-LEA.

Plate XXVi. Fig. 13.

Petaloconchus sculpturatus, $H$. C. Lea, Ter. fossils of Virginia, p. 7, pl. 34, fig. 3.

P. testa tubulata, costis longitudinalibus, nodulosis, inaqualiter convolutis, vermiformibus, duabus internis longitudinalibus laminis; laminis lavibus; apertura rotunda sine laminis.

Description. Shell tubular, with longitudinal, nodulous costæ, irregularly twisted, vermiform, with two internal longitudinal plates; plate smooth, mouth round and without plates.

This is the only species of the genus known. The internal longitudinal plates readily distinguish it from Vermetus. It is a variable shell in form.

Plate XXVI. Fig. 13. Natural size.

Locality. Sumterville. Museum, College of Charleston. 


\title{
SCALARIA.-LAM.
}

SCALARIA MULTISTRIATA.-SAY.

Plate XXVI. Fig. 14.

Scalaria multistriata, Say, Amn. Conch., pl. 27.

Scalaria multistriata, Gould, Invert. Mass., p. 251.

S. testa valde elongata; anfractibus convexis, complanatis; costis crebris modice elevatis; umbilico nullo.

Description. Shell greatly elongated, whorls convex, flattened; longitudinal ribs numerous, slightly elevated, spaces between them without lines, umbilicus none.

Our specimen is imperfect, but there can be no doubt as to its identity. It is a common species in the Post Pleiocene and recent upon the coast.

Plate XXVI. Fìg. 14, Natural size.

Locality. Smith's, Goose Creek. Museum, College of Charleston.

\author{
SCALARIA.-LAM. \\ S C A L A R I A C A THR U .
}

Plate XXVI. Fig. 15.

Scalaria clathrus, Say, Amn. Conch., pl. 27.

Our figure represents but a fragment, the lower whorls and ribs of SCALARIA CLATHRUs; it is a common shell on the coast, and fossil in the Post Pleiocene marl.

Plate XXVI. Fig. 15, A Fragment.

Locality. Smith's, Goose Creek.

Museum, College of Charleston. 


\section{BUCCINIDE.}

ACUS.-Humph. (1797.)

T E R E B R A.- LA M. ( 18001 .)

\section{ACUS DISLOCATUM.}

Plate XXVi. Fig. 16.

Terebra dislocatum, Say, Jour. Acad. Nat. Sci., Vol. 2, p. 235.

Terebra Carolinensis, Con., Sill. Jour., Vol. 4, p. 345.

A. tesia subulata attenuata; anfractibus crebris, parvis, spiralibus impressis lneis prominentibusque transversis costis instructis; costis transversis prope utriusgue anfractuum apicem linea convoluta valde impressa dislocatis.

Description. Shell subulate, attenuated; whorls with numerous minute revolving impressed lines, and prominent transverse ribs; near the summit of each whorl the transverse ribs are dislocated by a revolving line deeply impressed, which divides them into two series, the superior being shorter and thicker than the inferior.

A. Dislocatum is common on the shores of South Carolina. The fossil variety T. Carolinensis, Con., is figured in plate xxviii, fig. 8, with another A. unilineata, which was discovered after plate xxvi was finished.

Plate XXY. FIg. 18; shell natural size.

Locality. Waccamaw; Goose Creek.

Museum, College of Charleston. 


\title{
PYRAMIDELLIDE.
}

\section{O B E L I S C U S. - H U Р . ( 1797. )}

\author{
PYRAMIDELLA.-LAM. (1801.)
}

O B E L ISCUS ARENOSA.

Plate XXVI. Fig. 17.

Pyramidella arenosa, Con., Proceed. Acad. Nat. Sci., Vol. 1, p. 309.

O. testa subulata, lavi, ad suturam angulato-canaliculata; suture utrisque anfractibus crenulatis; duabus columellaribus plicis, quarum superior magna, acuta, inferior parva; labro tenui intus tribus parvis dentibus instructo.

Description. Shell subulate, smooth, angularly channeled at the suture, which is also crenulated on both whorls; columellar with two folds, the superior one large and acute the other small; outer lip thin with three small teeth internally.

This species is now living on the coast of South-Carolina.

Plate XXVI. Fig. 17. Natural size.

Locality. Waccamaw; Goose Creek. Museum, College of Charleston.

\author{
CYPREIDE. \\ CYPRÆA.LLINN, \\ C Y P R A CAROLINENSIS.-COX. \\ Plate XXViI. Figs. 1 and 2. \\ Cypræa Carolinensis, Con., Sill. Jour., Vol. 41, p. 346, pl. 11, fig. 6.
}

C. testa ovata, ventricosa; labri margine ad apicem prominenti; basi plano-convexa. 
Description. Shell ovate, ventricose, margin of the labrum prominent at the apex; base plano-convex.

The specimen from which our figure is drawn, still retains some of the coloured markings of the surface, which is maculated with small brownish yellow spots.

Plate XXVII. Figs. 1 and 2, Natural size.

Locality. Pee Dee; Goose Creek. Museum, College of Charleston.

C Y P R A PEDICULUS.-LIN.

Plate XXVII. Figs. 3 and 4

Cypræa pediculus, Linn., Syst. Nat., p. 1180 .

C. testa parva ovata, transverse costata; arcto dorsali sulco; utrisque lateribus maculatis; apertura lineali.

DEsCRiption. Shell small ovate transversely ribbed, with a narrow dorsal groove, and spots on each side; aperture linear.

This species is now living upon the coast.

Plate XXVII. Fig. 3, Side vien.

"4, View of aperture and base.

Locality. Pee Dee; Smith's, Goose Creek.

Museum, College of Charleston. 


\section{VOLUTIDE.}

\section{VOLUTA.-LINN.}

\section{O L U T A M U T A B I L IS.}

Plate XXVII. Figs. 5 and 6.

Fasciolaria mutabilis, Con., Jour. Acad. Nat. Sci., Vol. 7, p. 135.

Fasciolaria mutabilis, Con., Silliman's Amn. Jour. Sci. Vol. xLI. p. 346, pl. 11, fig. 7,

V. testa fusiformi; spira conica; apice sub-papillata; anfractibus convexis, versus suturas contractis, longitudinaliter undantibus; duabus columellaribus plicis modice elevatis; rostris sub-recurvis.

Description. Shell fusiform, spire conical, apex slightly papillated; whorls convex, contracted near the sutures, longitudinally undulated by the lines of growth; columella with two folds slightly elevated, beak recurved a little.

Plate XXVII. Fig. 5, Natural size.

" 6, A variety of same.

Locality. Pee Dee, and Goose Creek. Casts in the marl of Goose Creek are abundant.

Museum, College of Charleston.

V O L U T A T R E N H O L M I I.-(New Species.)

Plate XXVil. Fig. 7 and

T. testa fusiformi, ventricosa; anfractibus superne compressis, spiratim transverse striatis; striis ad basim crassioribus, rugosis; spira brevi, sub-cancellata, pupellata; apertura semilunari; labro acuto interne lavi; columellari labio temuissimmo, decumbenti, pane obsoleto, semi-calloso, ab basali anfractu modo linea externa coloreque distincto; columella aut varicosa aut tumida, tortua, oblique tribus plicis plicata. 
Description. Shell fusiform, ventricose, whorls compressed above, spirally and transversely striated; striæ at the base coarser and wrinkled; spire short sub-cancellated, papillated; aperture semi-lunar; outer lip acute, smooth within; columellar lip very thin decumbent, almost obsolete, semi-callous not distinguishable from body-whorl but by outline and color; columellar varicose or tumid, tortuous, obliquely plaited with three folds.

The tumid ridge which begins at the middle plication on the columellar, is formed by the successive termination of the siphonic notch or beak, and produced by the transverse lines of growth. The semi-callous decumbent lip, described above is obsolete in the adult shell as represented in plate xxvii, fig 8 .

We have inscribed this beautiful Volute to our valued friend George A. Trenholm, Esq., who so liberally sustained the publication of this expensive work, and enabled us to accomplish it in the first style of the art, ánd at home, in Charleston.

\title{
Plate XXVII. Fig. 7, A young shell from Waccaman.
}

" 8, An adult specimen, from Sumter.

Museum, College of Charleston.

\author{
MITRA.-LAM. \\ MITRA CAROLINENSIS-CON. \\ Plate XXVII. Frg. 9. \\ Voluta Carolinensis, Con., Sill. Am. Jour., 39, p. 387. \\ Mitra Carolinensis, Con., Sill. Am. Jour., 41, p. 345.
}

M. testa fusiformi; anfractibus infra suturam profunde sulcatis; sulci margine superiori carinato; spira elevata, prominens; lineis anfractuum superiorum elevatis, acutis, sub-carinatis; lineis anfractus basalis obscuris, ad basim tamen conspicuis; basi sulcata, valde striata; columellari labro septem obliquis plicis instructo, quarum superior profunda, duae inferiores pene obsoletce eadem magnitudine.

Description. Shell fusiform; whorls deeply channelled below the suture, superior 
margin of the channel carinated; spire elevated, prominent; lines on the superior whorls raised, acute, sub-carinated; on the body-whorl obscure, except on the base which is sulcated and strongly striated; the columellar lip has seven oblique plaits, the upper one profound, the two lowest are almost obsolete, and of the same size.

Plate XXVII. Fig. 9, Natural size.

Locality. Pee Dee.

Museum, College of Charleston.

POR CELLANA.-ADANS. (1757.)

MARGINELLA.-LAM. (1801.)

P $\ominus$ R CELLANA LI M T ULA.-CoN.

Plate XXVII. Figs. 10 and 11.

Marginella limatula, Con., Jour. Acad. Nat. Sci., Vol. 7, p. 140.

Porcellana limatula, Con., Proc. Acad. Nat. Sci., Vol. 7, p. 31.

P. testa ovata, polita; spira brevissima; labro interne denticulato; margine medio tumido; apertura superne contracta; columella quatuor obliquis elevatis plicis.

Description. Shell ovate, polished; spire very short; labrum denticulated on the inner margin; margin swelling in the centre, aperture contracted above; columellar with four oblique elevated plaits.

There is a common shell in the Post Pleiocene beds of South-Carolina, which we are disposed to consider a variety of this species; it differs in having a more elevated spire, and the columellar has but three plaits.

Plate XXVII. Figs. 10 and 11. Natural size.

Locality. Pee Dee.

Museum, College of Charleston. 


\section{P O R E L L A A O L I V I F O R M I S.-(New Species.) \\ Plate XXVIi. Fig. 12 and 13.}

P. testa elongato-ovali; spira profunde obtusa; apertura lineali, labro tumido, reflexo, intus profunde crenulato; columella tribus elevatis plicis.

Description. Shell elongated oval, spire profoundly obtuse; aperture linear, labrum tumid, reflexed, profoundly crenulated within, columellar with three equal raised plaits.

This species is unlike any of its fossil congeners. It may be readily distinguished by its profoundly crenulated outer lip, three robust plaits on the columellar, and the aperture which extends from the apex of the spire to the beak

Plate XXVII. Figs. 12 and 13, Natural size.

Locality. Sumter District.

Museum, College of Charleston.

\section{CONIDE.}

CONUS.-LINN.

CONUS ADVERSARIUS.-CON.

Plate XXVit. Fig. 14

Conus adversarius, Con., Sill. Jour. Amn. Sci., Vol. 39, p. 388.

C. testa sinistrali; lineis spiralibus obsoletis, ad basim tamen prominentibus; angulo basalis anfractus basique spiralium anfractuum carinatis; carina versus apicem sub-tuberculata; spira prominens.

Description. Shell sinistral, with obsolete spiral lines, except at base, where they are prominent; angle of body-whorl and base of the spiral whorls carinated; the carina slightly tuberculated towards the apex; spire prominent.

Plate XXVII. Fig. 14, Natural size.

Locality. Pee Dee.

Museum, College of Charleston. 
CONUS DILUVIA N S. - GREE.

Plate XXVII. Fig. 15.

Conus diluvianus, Green, Nat. Inst., No. 2.

C. testa dextrali; spira prominenti; apice acuto; basali anfractu lineis spiralibus sulcatis instructo; anfractibus superne carinatis; sutura distincta; apertura aque cum basalis anfractus longitudine prolatata, superne arctata.

Description. Shell dextral; spire prominent; apex acute; body whorl with spirally grooved lines, extending from the middle to base, obsolete on the upper part; whorls carinated above, suture distinct; aperture extending the whole length of body-whorl, and narrow above.

Plate XXVII. Fig. 15, Natural size.

Locality. Smith's, Goose Creek. Museum, College of Charleston.

TURRIS.-НUмРн. (1797.)

\section{P LEUROTOMA.-LAM. (1 $8 \begin{array}{lll} & 0 & 1 .)\end{array}$}

T URRIS LUNATUN.

Plate XXVII. Fig. 16.

Pleurotoma lunatum, Lea, Trans. Amn. Phil. Society, N. S. IX., pl. 37, fig. 93.

Pleurotoma lunatum, Foss. Ter. Shells of Virginia, p. 43, pl. 37, fig. 93.

P. testa sub-fusiformi, costata; apice acuto; anfractibus super medium concavis, infra convexis costatis; costis longitudinalibus obliquis, prominentibus, rotundatis; columella recta, crassa, polita, superne incrassata.

Description. Shell sub-fusiform, costate; apex acute; whorls angular above the 
middle, concave; below convex, ribbed; costæ longitudinal, oblique, prominent, rounded; columellar straight, thick, polished, incrassated above.

Plate XXVII. Fig. 15, Natural size.

Locality. Darlington.

Museum, College of Charleston.

\section{BUCCINIDE.}

\section{BUCCINUM.-LiNN.}

B U C CIN UM PORCINUM.-SAY.

Plate XXViII. Fig. 1.

Buccinum porcinum, Say, Jour. Acad. Nat. Sci., Vol. 4, p. 126.

Buccinum porcinum, Con., Foss. Ter. Form., Vol. 1, p. 19, tab. 4, fig. 4.

B. testa brevi, fusiformi; magnis longitudinalibus, rotundatis costis; spiralibus, elevatis, alterna vice minoribus lineis; rostris brevibus sub-reflexis.

Description. Shell short, fusiform, with large longitudinal rounded ribs and spiral elevated lines somewhat alternately smaller; beak short, slightly reflected.

Plate XXVIII. Fig. 1, Natural size.

Locality、 Darlington. Museum, College of Charleston.

BUCOINUM MULTIRUGATUM. - CONRAD.

Plate XXVIII. Fig. 2.

Buccinum multirugatum, Con., Sill. Jour., Vol. 41, p. 345.

B. testa ovata, conica, spiratim rugosa; columella crassa basali plica instructa; basi bicarinata. 
Descriptior. Shell ovate, conical, spirally wrinkled, columellar with a thick fold at base; base bicarinated.

Plate XXVili. Fig. 2, Natural size.

Locality. Pee Dee.

Museum, College of Charleston.

\section{B UCCIN U M VIBEX. - A DAMS.}

Plate XXVili. Fig 3.

Buccinum vibex, Adams, Boston Jour. Nat. Hist., Vol. 2, p. 264.

Nassa vibex, Say, Jour. Acad. Nat. Sci., Vol. 2, p. 231.

Nassa vibex, Say, Amn. Conch., pl. 57, fig. 2.

Buccinum vibex, Gould, Invert. Mass., p. 310, fig. 212.

B. testa brevi, crassa, ovato-conica; superficie undantibus plicis spiralibusque lineis impressa; 'labro incrassato intus dentibus instructo; columna lato crasso callo instructa.

Description. Shell short, thick, ovate-conic; surface checked with waving folds and spiral lines; lip thickened and toothed within; pillar with a broad and thick callus.

The elevated lines which cross the undulating folds or ribs are most distinct on the ribs.

Dr. Gould, in his work on the invertebrata of Massachusetts, says "specimens of this shell are rare, only found to the south of Cape Cod, and usually have a chalky aspect." It is not abundant on the Carolina coast, though often found recent upon our beaches. In the Post Pleiocene beds it is a common fossil. We are inclined to believe those from Massachusetts are also fossils from that formation.

Plate XXVIII. Fig. 3, Natural size.

Locality. Pee Dee.

Museum, College of Charleston. 
B U C C I N U TRIVITTATUM.-A n A M S.

Plate XXViII. Fig. 4.

Nassa trivittata, Say, Jour. Acad. Nat. Sci., Vol. 2, p. 231.

Buccinum trivittatum, Adams, Boston Jour. Nat. Hist., Vol. 2, p. 265.

Buccinum trivittatum, Gould, Invert. of Mass., p. 309.

B. testa ovato-conica, cancellata; superficie lineis decussatis reticulata; labro aut duabus aut tribus dentibus vel lineis elevatis intus instructo; apice acuto.

Description. Shell ovate-conic, cancellate; the surface presenting a net-work of decussating lines; lip with two or three teeth or raised lines within; apex acute.

This species, like its predecessor, when found on the north-eastern shores of the United States has usually a chalky aspect, and we have no doubt is from the fossil beds of the Post Pleiocene; in advancing southwards it is more abundant, and living specimens can be had in quantity on the southern coast.

It is by no means uncommon in the Pleiocene beds of South Carolina.

Plate XXVIII. Fig. 4, Natural size.

Locality. Waccamaw.

Museum, College of 'Charleston.

B UCCINUM OBSOLETUM.-ADAMS.

Plate XXViII. Fig. 5.

Nassa obsoleta, Say, Jour. Acad. Nat. Sci., Vol. 2, p. 232.

Buccinum Nov.-Eboracensis, Wood, Index Suppt., pl. 4, fig. 26

Buccinum oliviforme, Kiener, Iconog. pl. 25, fig. 99.

Buccinum obsoletum, Adams, Boston Jour. Nat. Hist., Vol 2, p. 267.

Buccinum obsoletum, Gould, Invert. Mass., p. 308, fig. 210.

B. testa ovata; superficie lineis reticulata quasi granulata; spira corpore breviori; labro paucis lineis elevatis interruptis usque ad labri marginem non productis instructo; labri margine simplici, acuto; columna lato callo tecta. 
Description. Shell orate, surface covered with a net-work of lines which give it a granulated appearance; spire shorter than the body; right lip with a few elevated lines which are interrupted, and do not extend to the margin of the lip, which is simple and sharp; pillar covered with a broad callus.

This is a most abundant shell along the whole coast of the Atlantic shore, and is found fossil in the Post Pleiocene in great numbers.

Plate XXVIII. Fig. 5, Natural size.

Locality. Waccamaw ; Smith's, Goose Creek.

Museum, College of Charleston.

\author{
B U C CIN UM L U N T UM.-ADAMS. \\ Plate XXvili. Fig. 6.
}

Nassa lunata, Say, Jour. Acad. Nat. Sci., Vol. 5. p. 213.

Buccinum lunatum, Adams, Boston Jour. Nat. Hist., Vol. 2, p. 266.

Buccinum lunatum, Gould, Invert. Mass. p. 312, fig. 196.

B. testa parva, ovato-conica; superficie lavi; apertura ovali; labro intus dentato.

Description. Shell small, ovate-conic, surface smooth, aperture oval; outer lip toothed within.

This small, but very abundant shell of the southern coast is well represented in the fossil state in the Pleiocene of South Carolina, and found in numbers in the Post Pleiocene.

Plate XXVIII. Fig. 6, Natural size.

Locality. Pee Dee; Smith's, Goose Creek.

Museum, College of Charleston. 


\section{A C US. - H U M H. (1 797.$)$}

TEREBRA.-LAM.

\section{A C US UNILINEATA.}

Plate XXVIII. FIG. $\uparrow$.

Terebra unilineata, Con., Sill. Jour. Sci., Vol. 41, p. 345, pl. 11, fig. 4.

A. testa sub-turrita; anfractuum utrisque spirali impressa linea instructis; plicis obliquis inter suturam lineam que supradictam interjectis.

Description. Shell slightly turrited, whorls each with a spiral impressed line, between which and suture obliquely plicated.

Plate XXViII. Fig. 7 .

Locality. Sumter.

Museum, College of Charleston

ACUS OAROLINENSIS.

Plate XXVIII, Fig. 8.

Terebra Carolinensis, Con., Sill. Jour., Vol. 41, p. 345.

This we conclude to be a large variety of A. Dislocatum; for description of which see page 125 , plate xxvi, fig. 16 .

PURPURA.-ALdROVANDUS.

P URPURA TRIDENTATA.-(New Species.)

PLate XXVIII. Fig. 9.

P. testa ovali, crassa; spira brevi; anfractibus tenuiter sulcatis, spiratim striatis, transverse costatis, superne compressis, infra suturam canaliculatis; costis late separatis, superne 36 
nodulosis, ad basim obsoletis; labro crasso, intus crenulato tribus ad canalem posteriorem dentibus instructo; labio lavi, una conspicua plica superne instructo; columella complanata; apertura bi-canaliculata.

Description. Shell oval, thick; spire short; whorls finely sulcated and striated spirally, transversely costated, compressed above, and channeled below the suture; costæ widely separated, nodulous above and obsolete at the base; labrum thick, crenulated with three prominent teeth at the posterior canal; columellar lip smooth, with one prominent plait above; columellar flattened; aperture bi-canaliculated.

This shell resembles the recent species of the coast, P. cataratca, Lam., but can be readily distinguished by the three prominent teeth on the labrum at the entrance of the posterior canal. The artist has failed to exhibit distinctly the characteristic teeth on the labrum.

Plate XXVIII. Fig. 9, Natural size, with the apex of the spire broken off.

Locality. Black River. Museum, College of Charleston.

\author{
GALEODIA.-LiNK. \\ GALEODIA HODGII.-CON. \\ Plate XXVili. Fig. 10
}

Cassis Hodgii, Con., Sill. Amn. Jour. Sci., Vol. 41, p. 346, pl. 2, fig. 10.

Galeodia Hodgii, Con., Pro. Acad. Nat. Sci., Vol. 8, p. 30.

G. testa elliptica, crebis spiralibus lineis prope basim prominentioribus; sutura depressa.

Description. Shell elliptical, with numerous spiral lines most prominent near the base; suture depressed.

The spiral lines are quite characteristic of this fine species.

Plate XXVIII. Fig. 10, Natural size.

Locality. Pee Dee.

Museum, College of Charleston. 
D O L I U M. - B R OW N .

D O L I U M GALEA.

Plate XXVIII. Fig. 11.

Dolum galea, Linn, Kienery, pl. 2, fig. 2 .

D. testa globosa, ventricosa, tenui; spira depressa; apertura magna; anfractibus spiratim costatis; costis convexis alterna vice magnis et parvis; sutura profunde excavata.

Description. Shell globular, ventricose, thin; spire depressed; aperture large; whorls spirally ribbed; costæ convex, alternately large and small, suture deeply excavated.

Our figure is taken from a cast found in the marl of Goose Creek, where numerous specimens may be easily obtained, and some of a large size. It is common on our sea coast.

Plate XXVIII. FIG. 11, External vien of natural cast.

Localiti Smith's, Goose Creek. Museum, College of Charleston.

COLUMBELLA.-LAM.

C 0 L U M B E L A A VARA-CON.

Plate XXVIII. Fig. 12.

Columbella avara, Say, Jour. Acad. Nat. Sci., Vol. 2, p. 230.

Columbella avara, Gould, Invert. Mass., p. 313, fig. 197.

C. testa parva elongato-ovata; spira acuta, elevata; anfractibus spiralibus impressis lineis costisque transverse elevatis instructis; basalis anfractus costis circiter medium terminantibus; lineis in basim spiralibus distinctis; labro intus denticulato; labio lamina distincta, submargine crenato; sutura distincta; apertura testce longitudinis circiter triente aqua.

Description. Shell small, elongated-ovate; spire pointed, elevated; whorls with spiral impressed lines, and transverse elevated ribs; ribs on body-whorl terminate about the middle; spiral lines on the base distinct; labrum denticulated within; columellar lip with 
a distinct plate crenated on sub-margin; suture distinct; aperture about one-third the length of the shell.

This is an abundant species in the Post Pleiocene beds, and common in a recent state on the southern sea-shores.

Plate XXVIII. Fig. 12, Natural size.

Locality. Waccamaw.

Museum, College of Charleston.

\author{
STREPHONA.-BROWNE. (1756.) \\ OLIVA.-LAM. (1801.) \\ STREPHONA LITERATA.
}

Plate XXVIII. Fig. 13.

Oliva literata, Lam., Anim. sans Vert., Vol. 10, p. 614.

Oliva literata, Say, Amn. Conch., pl. 3.

S. testa cylindrica, crassa, lavi; spira exserta, acuta; anfractibus angularibus, marginibus superioribus carinatis; sutura profunde sulcata; labro acuto, simplici, lavi; labio multiplicato; apertura lineali, superne incisa, inferne emarginata.

Description. Shell cylindrical, thick, smooth; spire exserted, acute; whorls angular, carinated at the superior margins; suture deeply grooved; labrum acute, simple, smooth; labium with many folds; aperture linear, insised above, emarginate below.

This is a common shell in the Post Pleiocene, and recent upon the coast.

Plate XXVIII. Fig. 13, Natural size.

Locality. Smith's, Goose Creek; Pee Dee.

Museum, College of Charleston. 


\section{MURICIDE.}

MUREX.-LIN.

\section{CEROSTOMA-CoN.}

CEROSTOHA I I B RIFER.-CON.

Plate XXViII. Fig. 14.

Murex umbrifer, Con., Foss. Shells Ter. Form., Vol. 1, p. 17, tab. 3, fig. 1.

Cerostoma umbrifer, Con., M. S.

C. testa fusiformi, sex foliatis, reflexis laminis; anfractibus angularibus, carinatis; apertura ovata; rostris recurvis.

Description. Shell fusiform with six foliated reflected laminæ; whorls angular and carinated, aperture ovate, beak recurved.

Mr. Conrad informs us it is but lately that specimens of this shell have been discovered with the erect tooth on the labrum, which places it in his sub-genus CErostoma. It is a common shell of the Meiocene of Virginia; but a single specimen yet found in the Pleiocene of South Carolina that we know of, and that is imperfect, the spire is broken off, as represented in the figure.

Plate XXVIII. Frg. 14, Natural size.

Locality. Smith's, Goose Creek.

Museum, College of Charleston. 
APOLLON.-MontF. (1810.)

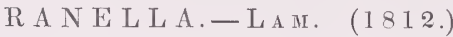

A P OLLON CAUDATA.

Plate XXVIII. Fig, 15.

Ranella caudata, Say, Amn. Conch., pl. 48.

Ranella caudata, Gould, Invt. Mass., p. 297, fig. 204.

A. testa rhomboidea, crassa, lineis convolutis costisque longitudinalibus tessellata; canali longi, recto; apertura ovata; labro crasso, margine elevatis granulis lineisque instructo.

Descriptron. Shell rhomboidal, thick, checkered with revolving lines and longitudinal ribs; canal long and straight, aperture ovate, outer lip thick, margin with raised granules and lines.

This shell is found all along the A tlantic coast from Buzzard's Bay to Florida, but more abundant at the south than the north.

Plate XXVIII. Fig. 15, Natural size.

Locality. Darlington. Museum, College of Charleston.

CANCELLARIA.-LAN.

CA N C EL LA R A RETICULATA.- LAM.

Plate XXVIII. Fig 16.

Voluta reticulata, Lin., Syst. Nat., p. 1190.

Cancellaria reticulata, Lam., Anim. sans Vert., Vol. 9, p. 401.

C. testa ovata, ventricosa, crassa; spira brevi, acuta; anfractibus longitudinaliter trans- 
verse que sulcatis, oblique reticulatis; apertura sub-ovata, antice emarginata, postice acuta; labro intus transverse striato; columella recta, crassa, obtusa, longis obliquis plicis; columna sub-umbilicata; sutura distincta sed compressa.

Description. Shell ovate, ventricose, thick; spire short, acute; whorls longitudinally and transversely grooved, obliquely reticulated ; aperture sub-ovate, emarginated anteriorly, pointed at posterior extremity, labrum marked within with transverse ridges, columellar straight, thick, obtuse, with strong oblique folds; pillar sub-umbilicated, suture distinct but compressed.

This species is found recent on the southern coast.

Plate XXVIII. Fig. 16, Natural size.

Locality. Pee Dee.

Museum, College of Charleston.

C A N GELLA R I DEPRESSA.-(Nero Spocies.)

Piate Xxvili. Fis. 17 .

C. testa ovata, ventricosa, crassa, sub-umbiticata; spira brevi, turrita, obtusa; anfractibus angularibus, longitudinaliter transverseque sulcatis, oblique crasse reticulatis; basalis anfractus striis elevatis alterna vice minoribus; sutura excavata, profunda; labro late separatis transversis striis intus instructo; labio in basalim anfractum reflexo, tenui; columella duabus obsoletis plicis inter duas magnas plicas interpositis instructa; apertura sub-ovata, antice emarginata, postice acuta.

Description. Shell ovate, ventricose, thick, sub-umbilicated; spire short, turrited obtuse; whorls angular, longitudinally and transversely grooved, obliquely and coarsely reticulated; raised striæ of body whorl alternately smaller; suture excavated, deep; labrum with widely separated transverse ridges within; labium reflexed upon the body whorl, thin; columellar with two strong folds and two obsolete ones between; aperture sub-ovate, anteriorly emarginate, posteriorly pointed. 
The alternately prominent and depressed spiral lines, excavated sutures, and turrited spire readily distinguish this species.

Plate XXVIII. Fig. 17, Natural size.

Locality. Waccamaw ; Horry.

Museum, College of Charleston.

C A N C ELLARIA VEN U T A.- -(New Species.)

Plate XXVIII. Fig. 18.

C. testa sub-fusiformi, turrita, regulariter cancellata; anfractibus transverse sulcatis, longitudinatibus obliquis costis; labio in basalim anfractum reflexo, lovi: margine distincto, elevato; columella duabus prominentibus sub-obliquis plicis; labri margine denticulato, intus decem transversis, equidistantibus, rectis, longis striis, instructo; apertura valde auriculata, emarginata; sutura profunda.

Description. Shell sub-fusiform, turrited, regularly cancellated; whorls with longitudinal, oblique ribs, sulcated transversely; inner lip reflexed on body whorl; smooth and with a distinct raised edge, extending from the base of the pillar and uniting above with the labrum in an arch; columellar with two prominent folds slightly oblique; margin of outer lip scolloped, transversely ridged within with ten ridges ; ridges equi-distant, straight, long; aperture profoundly ear-shaped, emarginate; suture profound.

This is the most graceful of all its congeners, and cannot be confounded with any other.

Plate XXVIII. Fig. 18, Natural size.

Locality. Waccamaw; Horry.

Museum, College of Charleston. 


\title{
B USYCON.-B OL TON. (1798.)
}

\author{
FULGUR.-MontF. (1810.) \\ BUSTCON CA R C A. - CON. \\ Plate XXIX. Fig. 1.
}

Murex carica, Gmel., Lister's Conch., t. 880.

Pyrula carica, Adams, Boston Jour. Nat. Hist., Vol. 2, p. 269.

Pyrula carica, Gould, Invert. Mass. p. 296.

Fulgur carica, Con., Proceed. Acad. Nat. Sci., Vol. 7, p. 319.

Busycon carica, Con., Pro. Acad. Nat. Sci., Vol. 8, p. 30.

B. testa pyriformi, ventricosa, crassa, ponderosa, transverse tenuiter striata; spira nonturrita; sutura non-canaliculata; labro simplici, acuto; labio flexuoso, superne concavo.

Description. Shell pyriform, ventricose, thick, ponderous, transversely and finely striated; spire not turrited ; suture not channelled, but having a series of triangular, compressed, tubercles above; large ones around the prominent part of body whorl; outer lip simple, sharp; pillar lip flexuous, concave above.

Common in a recent state on this Atlantic coast and often attains a great size.

Plate XXIX. Fig. 1, Natural size.

Locality. Waccamaw.

Museum, College of Charleston.

BUSYOON PERVERSUM.-CON.

PIATE XXIX. FIG, 3

Buccinum ampullaceis ad sinistram convolutis, Lister, Conch., t. 907, 908.

Pyrula perversa; Lam., An. sans Vert., Vol. 9, p. 506.

Pyrula perversa, Reeve, Conch. Icon., pl. 3, fig. 13.

Busycon perversum, Con., Pro. Acad. Nat. Sci., Vol. 7, p. 31.

B. testa pyriformi, sinistrali, ventricosa; anfractuum apicibus inclinatis; basalis anfractus parte prominenti coronata, tuberculata; spira non-turrita; sutura non-canaliculata, distincta. 
Description. Shell pear shaped, sinistral, ventricose ; summit of each whorl inclined; prominent part of whorl coronated, tuberculated; spire not turrited; suture not canaliculated, but distinct.

The recent specimens have often all the whorls coronated at their summits; it is a common shell on the southern coast.

Plate XXIX. Fig. 3, Natural size.

Locality. Pee Dee; Smith's, Goose Creek.

BUSYGON CANALICULATUM.-Cos.

Plate XXIX. Fig. 2.

Buccinum ampullaceum, Lister Conch., t. 878, fig. 2.

Murex canaliculatus, Linn, Martini, Vol. 3, p. 29, t. 67, figs. 742, 743.

Pyrula canaliculata, Reeve, Conch. Icon., pl. 8, fig. 26.

Pyrula canaliculata, Gould, Invert. Mass., p. 294, fig. 206.

Fulgur canaliculatum, Con., Pro. Acad. Nat. Sci., Vol. 6, p. 319.

Busycon canaliculatum, Con., Pro. Acad. Nat. Sci., Vol. 7, p. 30.

B. testa pyriformi; anfractibus in apicem planatis, lineis convolutis tectis; basali anfractu tumido, canale longo terminato; angulo utriusque anfractus noduloso; sutura profunde sulcata.

Description. Shell pear shaped; whorls flattened on the summit, covered with revolving lines; body whorl tumid, terminating in a long canal; angle of each whorl nodular, suture deeply channelled.

The nodular keel which crowns the summit of each whorl, and the deeply channelled suture will distinguish this species readily.

Common in a recent state on this coast.

Plate XXIX. Fig. 2, Natural size.

LocalitTy. Waccamaw.

Museum, College of Charleston 


\section{B U S Y CON C O N R A D I I.-(New species. $)$}

Plate XXIX. Fig. 4

B. testa sub-pyriformi, ventricosa; anfractibus medio convexis, superne angulatis, densis rugosis lineis spiratim striatis; spira brevi, turrita; sutura profunde lateque excavata, lateribus rectis, obtusa, carina marginata; apertura postice aut emarginata aut contracta, antice canaliculata; rostris recurvis; labio concavo; labro acuto, obsolete dentato.

Description. Shell sub-pyriform, ventricose; whorls convex in the middle, angulated above; spirally striated, with closely arranged wrinkled lines; spire short, turrited; suture deeply and widely excavated, with straight walls or sides, margined by an obtuse carina; aperture posteriorly emarginated or contracted, anteriorly canaliculated; beak recurved, pillar lip concave, outer lip acute, dentations obsolete.

This shell resembles somewhat B. Canaliculatum, but is distinguished by being more ventricose, without tubercles or spines on the whorls; the whorls of the spire convex on the sides, flattened or inclined between the obtuse ridge which margins the suture and the angle of the whorl; angles of the two superior whorls of the spire slightly nodulous ; the beak is slightly recurved in adult shells.

We name this species in compliment of T. A. Conrad, Esq., the distinguished palæontologist.

Plate XXIX. Fig. 4.

Locality. Sumter. Museum, College of Charleston

\section{CASS IDULUS.-HUMPH. (1797.)}

PYRULA.-LAM. (1822.)

C A S I D ULUS CAROLINENSIS.-(New Species.)

Plate XXX. Fig. 1.

C. testa pyriformi; spira brevi, depressa; sutura profunde canaliculata, obtusa ad anfrac- 
tus angulum carina marginata; basali anfractu superne truncato, angulato; spirce anfractibus medio angulatis, in apicem sub-inclinatis; anfractibus temuis, convolutis, indistinctis lineis instructis; in basalis anfractus basim prominentibus, undantibus lineis; canale longo, attenuato.

Description. Shell pear shaped; spire short, depressed; suture profoundly canaliculated, margined by the obtuse carina at the angle of the whorl; body whorl truncated above, angular; whorls of the spire angulated in the middle, and inclined slightly to summit, having fine revolving lines, indistinct, but prominent and waved on the base of body whorl; canal long, tapering.

The widely canaliculated spire and subtruncated whorls distinguish this from its congeners, and are very characteristic.

Plate XXX. Fig. 1, Natural size.

Locality. Sumter.

Museum, College of Charleston.

\author{
CASSIDULUS PYRUM. \\ PLATE XXX. Fig. 2
}

Bulla pyrum, Dill., Cat., p. 485.

Buccinis ampullaceis tenuibus, Lister Conch., t. 877.

Pyrula spirata, Lam., An. sans Vert., 9, p. 512.

Fulgur pyruloides, Say, Amn. Conch., pl. 19.

Pyrula spirata, Reeve, Conch., Icon., pl. 8, fig. 27.

Fulgur pyrum, Con., Pro. Aca. Nat. Sci., Vol. 6, p. 319.

Fulgur pyruloides, Say, Jour. Acad. Nat. Sci., Vol. 2, p. 237.

C. testa pyriformi, spiratim striata, superne complanata, inermi; sutura canaliculata; spira brevi, exserta.

Descriprion. Shell pear shaped, spirally striated, flattened above, unarmed; suture canaliculate. Spire, short, exserted.

Large specimens of this shell common on the southern coast.

Plate XXX. Fig. 2.

Locality. Pee Dee.

Museum, College of Charleston. 


\title{
SYCOTYPUS.-BRownE. (1756.)
}

FICTS.-BoLten. (1793.)

SYCOTYPUS RETICULATA.

Plate XXX. Fig. 3.

Pyrula recticulata, Lam., Anim. sans Vert., p. 510.

S. testa pyriformi, tenuissima, cancellata; spira brevi, convexa, exserta; superficie striis convolutis, prominentibus, alterna vice minoribus, distantibus, tenuisque lineis reticulata; labro acuto, superne arcuato; labio concavo; canali brevi, recto, truncato.

Description. Shell pear shaped, very thin; cancellated; spire short, convex, exserted; revolving striæ prominent, alternately smaller, distant, crossed by fine lines, which give the surface a reticulated appearance; outer lip acute, arched above; inner lip concave; canal short, straight, truncate.

This species is recent on the coast of Florida, Georgia, and the Carolinas.

Plate XXX. Fig. 3, Natural size. The reticulations are not very distinct in the figure.

Locality. Sumter.

Museum, College of Charleston.

\author{
COLUS.-HumP. (1797.) \\ F US US.-LA M. (18001.) \\ COTLE QUADRICOSTATUS. \\ PLATE XXX. FIg. 4
}

Fusus quadricostatus, Say, Jour. Acad. Nat. Sci., 4, p. 127.

C. testa ovato-ventricosa; anfractu basali quatuor elevatis, equidistantibus annulis instructo; spira brevi, duobus annulis in convolutiones, reliquis annulis ab anfractibus occultis; labro 
sulco utræque exteriorum costarum correlato; umbilico magno, dilato; margine exteriori prominenti, dentato.

Description. Shell ovate ventricose, body whorl, with four elevated belts equi-distant; spire short, with but two belts upon the volutions, the others concealed by the succeeding whorls; labrum with a groove corresponding with each of the exterior ribs; umbilicus large, dilated; exterior margin prominent and dentated.

Plate XXX. Fig. 4. Natural size.

Locality. Pee Dee. Museum, College of Charleston.

\section{COLUS EXILIS \\ Plate XXX. Fig. 5.}

Fusus exilis, Con., Fos. Shells, Ter. Form., p. 17, Tab. 3, fig. 2.

C. testa fusiformi, elongata; longitudinalibus undulantibus costis; striis convolutis, acutrs, elevatis, alterna vice minoribus; rostris productis; apertura testa longitudinis dimidiarn aquante.

Descrittion. Shell fusiform, elongated, with longitudinal undulated ribs and revolving striæ, acute, elevated, alternately smaller; beak produced; aperture half the length of shell.

The elongated spire, and produced beak distinguishes this species from C. cinekeous, which it resembles.

Plate XXX. Fir. 5.

Locality. Pee Dee.

Huseum, College of Charleston.

\section{COLUS CINEREUS. \\ Plate XXX. Fig. 6.}

Fusus cinereus, Say, Jour. Acad. Nat. Sci., Vol. 2, p. 236.

C. testa fusiformi, cancellata, transverse costata; costis magnis; lineis convolutis filiformis, 
irregularibus, alterna vice minoribus; labro acuto, intus crenato, elevatis lineis alternantibus; rostris brevibus, obtusis.

Description. Shell fusiform, cancellate, transversely costate; costæ robust; revolving lines filiform, irregular, alternately smaller; labrum acute, crenated within, and alternating with the raised lines; beak short, obtuse.

Common on the shores of South Carolina.

Plate XXX. Fig. 6.

Locality, Waccamaw.

Museum, College of Charleston.

FASCIOLARIA-LAM.

FASGIOLARIA DISTANS.-LAs.

Plate XXX. Figs. 7 axd 8.

Fasciolaria distans, Lam., An. sans Vert., Vol. 9, p. 433.

Fasciolaria distans, Kiener, pl. 3.

F. testa fusiformi, ventricosa, longitudinaliter temuiter striata; anfractibus fuscis late separatis annulis transverse impressis; suturis simplicibus; spira prominenti, acuta; columna una plica.

Description. Shell fusiform, ventricose, longitudinally finely striated; whorls marked transversely by dark colored and widely separated bands; sutures simple; spire prominent, acute; pillar with one plait.

The dark bands are characteristic of this species; fossil specimens have but faint traces of these markings upon the surface.

It is common in a recent state upon the southern coast.

Plate XXX. Figs. 7 and 8.

Museum, College of Charleston. 


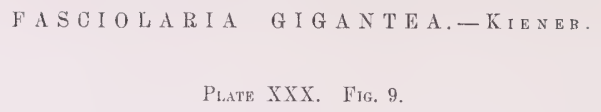

Fasciolaria gigantea, Kiener, pl. 3. p. 10 and 11.

Our figure is of a small natural cast from the Pleiocene of Goose Creek; no perfect shell yet found.

Plate XXX. Fig. 9.

Museum, College of Charleston.

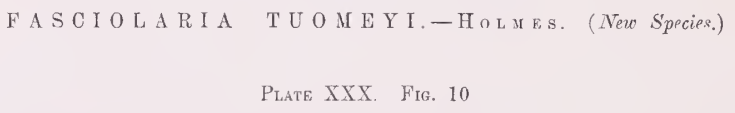

F. testa fusiformi; anfractibuslineis convolutis elevatis; anfractibus superioribus transverse, obtuse striatis; apertura elliptica; labro non-incrassato; columella prope basim plicata; rostris sub-reflexis.

Description. Shell fusiform; whorls with raised revolving lines, the upper ones with transverse, obtuse ridges; aperture elliptic; outer lip not thickened; columellar with a fold near the base; beak a little reflected.

The absence of ribs upon the body whorl and the more fusiform character of this shell, distinguishes it from F. RHOMBOIDEs.

Dedicated to our deceased friend and co-laborer, Prof. M. Tuomey, who discovered it.

Plate XXX. Fig. 10.

Locality. Black River, Sumter District. Museum, College of Charleston. 



\title{
PLEIOCENE FOSSILS.
}

\author{
PLATE I
}

P OLYPARIA.

Fig. 1. ASTR EA BELLA. Coral, natural size, on a fragment of Pecten, page 1.

" 1a. A single star nuagnified.

"2. ASTREA MARYLANDICA. Coral, natural size, page 2.

" 2a. A single star magnified.

" 3. ENCOPE MACROPHORA. Upper surface, natural size, page 2.

"3b. Lower surface.

"3a. Profile.

“ 4. MELLTTA CAROLINIANA. Upper surface, page 3.

"4b. Lower surface,

"4a. Profile view.

“ 5. AGASSIZIA PORIFERA. Upper surface, natural size, page 5.

" 5 b. Lower surface.

"5a. Profile view. 
1.

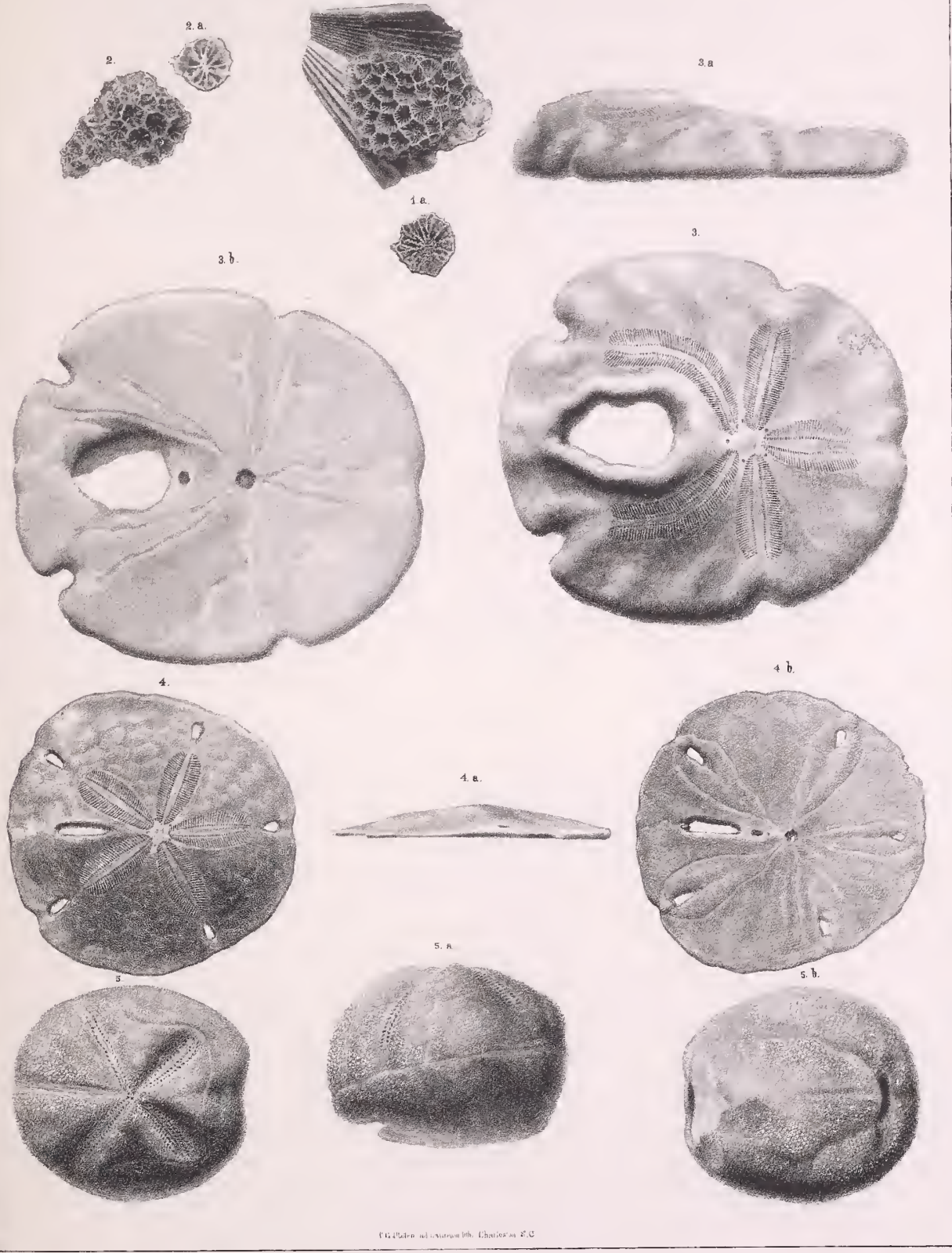






\section{PLEIOCENE FOSSILS.}

PLATE I.

E C H I N O D E R M A T.

Fig. 1. Upper surface of AMPHIDETUS ORTHONOTUS, a fossil from the Miocene Marl of James River, Virginia ; introduced here for comparison. Unfortunately by a mistake in the position in which this view was taken, the sexuch centre appears to be behind the actucl centre of the shell, instead of being before it, as in nature. Fig. $1 \mathrm{c}$ is more correct in this respect.

" 1 a. Lower surface.

" 1b. Altitude from behind.

" 1c. Profile.

" 2. AMPHIDETUS AMPLIFORUS, upper surface, page 6.

" 2a. Profile.

“ 3. AMPHIDETUS GOTHICUS, upper surface, page 7.

" $3 a$. Lower surface.

" 33. Altitude from behind.

“ $3 c$. Profile.

" 3 d. Magnified view of the minute granulations of the upper surface.

" 3 e. Vicw of some tubercles from the lower surface, with a portion of half the next lying ambulacrum, less highly magnified than Fig. $3 d$.

" $3 f$. A tubcrele from the lower surface, with its shield highly magnificd.

"4. Enlarged view of part of an ambulacrum of the forward pair, from AGASSIZIA PORIFERa, (Plate 1, Fig. 5) showing the minute pores of the obsolete half row.

" $4 a$. Magnified view of a large tubercle from beside the odd ambulacrum.

“ 5. ECHINO-CIDARIS, upper surface, as restored from sereral fragments; species doubtful.

" $5 a$. Profile view of the same.

“6. PSAMMECHINUS EXOLETUS; a fragment magnified about twice the natural size, page 4. 


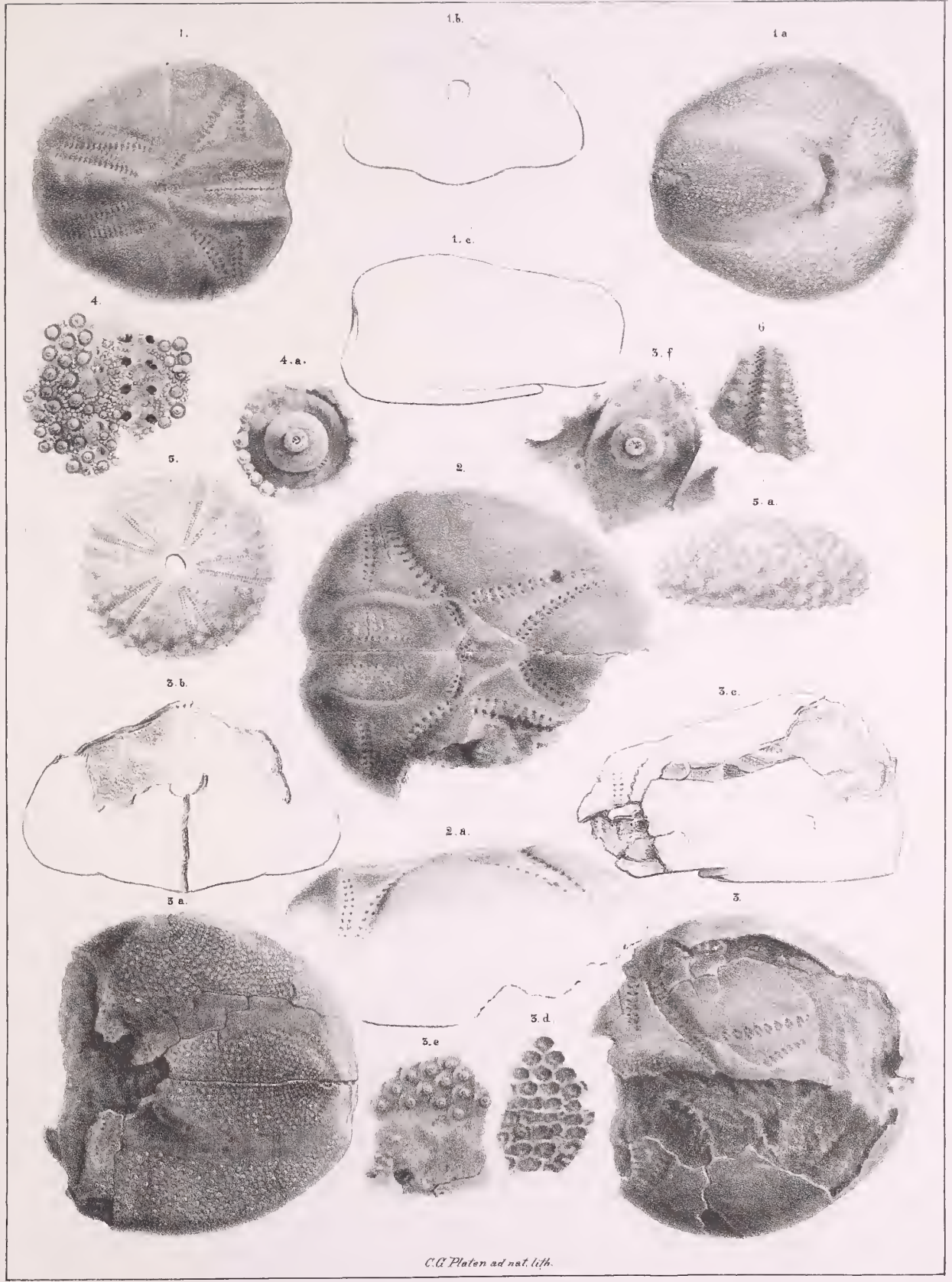




\section{PLEIOCENE FOSSILS.}

\section{PLATE III}

\section{E C H I N 0 D E R M A T A.}

Fig. 1. BRISSUS SPATIOSUS. Upper view of cast.

" 1a. A Breastplate, with part of the hinder ambulacrum of the left side.

“ 16. Enlarged knops, with their characteristic pentagonal shields from the lower surface.

" 1c. Profile view of another knop of the same kind.

“ 2. PLAGIONOTUS HOLMESII. Lower part of the hinder half-row from the right ambulacrum of the forward pair, with forward half-row of the interambulacrum immediately behind.

“ 2a. Breastplate nearly entire.

“ 3. PLAGIONOTUS RAVENEIIANUS. The part of this species corresponding to fig. $2 a$ of $\mathrm{P}$. HoLmesin, but more perfect. It will be observed that the Belt-bearing plate is without any row of great knops.

« $3 a$. Imperfect Breastplate. 

P1. 3.

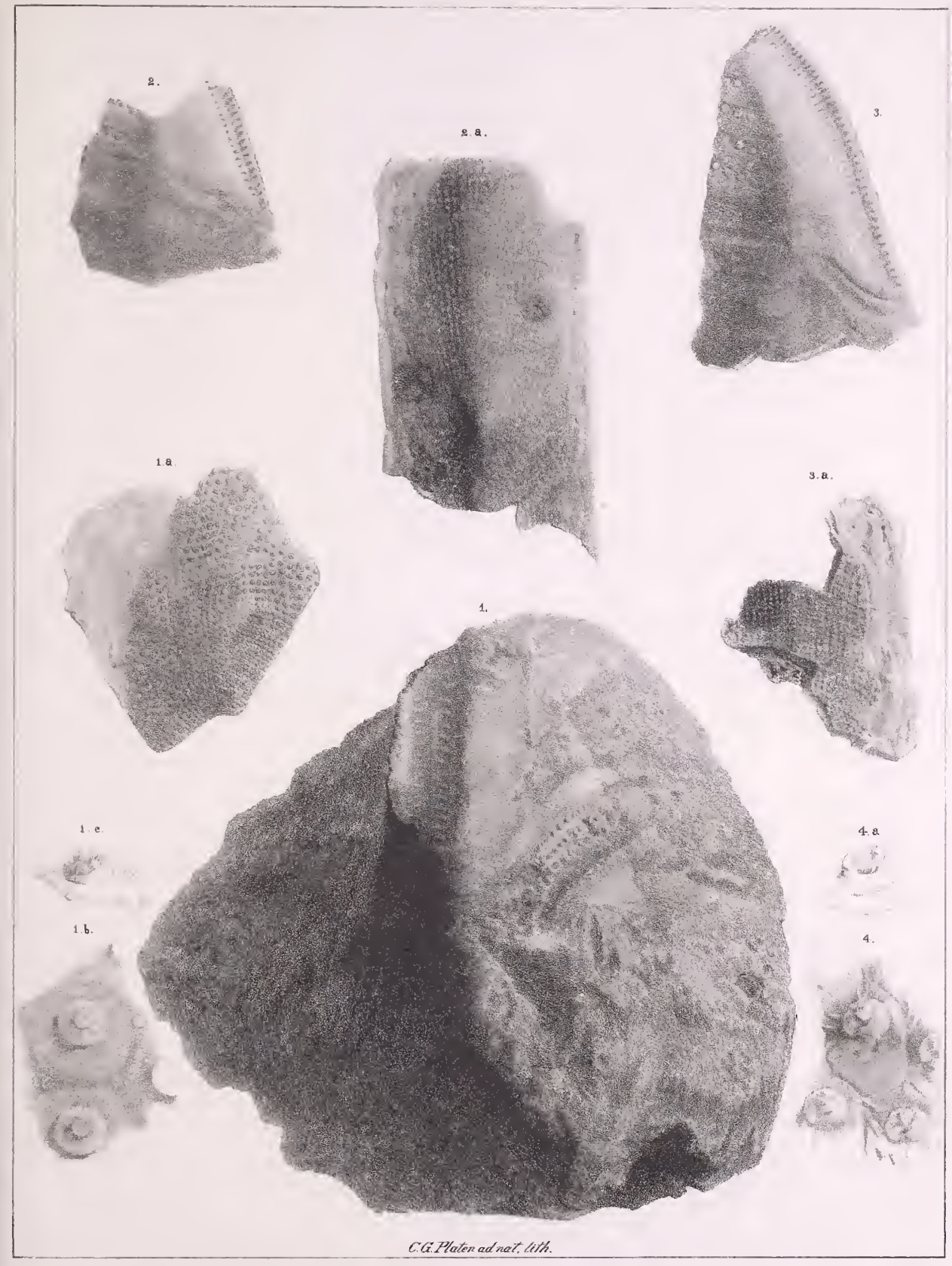





\section{PLEIOCENE FOSSILS.}

PLATE IV.

B R Y 0 Z $0 \mathrm{~A}$.

Fig. 1. LUNULITES DENTICULATA. Coral, natural size.

“2. Coral magnified.

“ 3. Interior, natural size.

" 4. Interior magnified.

“ 5. Cells magnified.

“6. CELLEPORA FORMOSA. Coral, magnified.

“ 7. CELLEPORA TESSELLATA. Coral, magnified.

“ 8. CELLEPORA RADIATA. Coral, magnified.

“9. CELLEPORA DEPRESSA. Coral, magnified.

“ 10. MEMBRANIPORA LACINIA. Coral, magnified.

“ 11. REPTOCELLEPORARIA INFORMATA. Coral, natural size.

" 12. Cells magnified.

“ 13. REPTOCELLEPORARIA SIMILTS. Coral, natural size.

"14. Cells, magnified.

“ 15. HETEROPORA TORTILTS. Fragment of Coral, natural size.

"16. Same magnified, to show the pores; the lower part cut to show internal structure.

" 17. Fragment from Virginia, natural size, to show the branching.

"18. Magnified view of irregular pores. 

Pl. t.

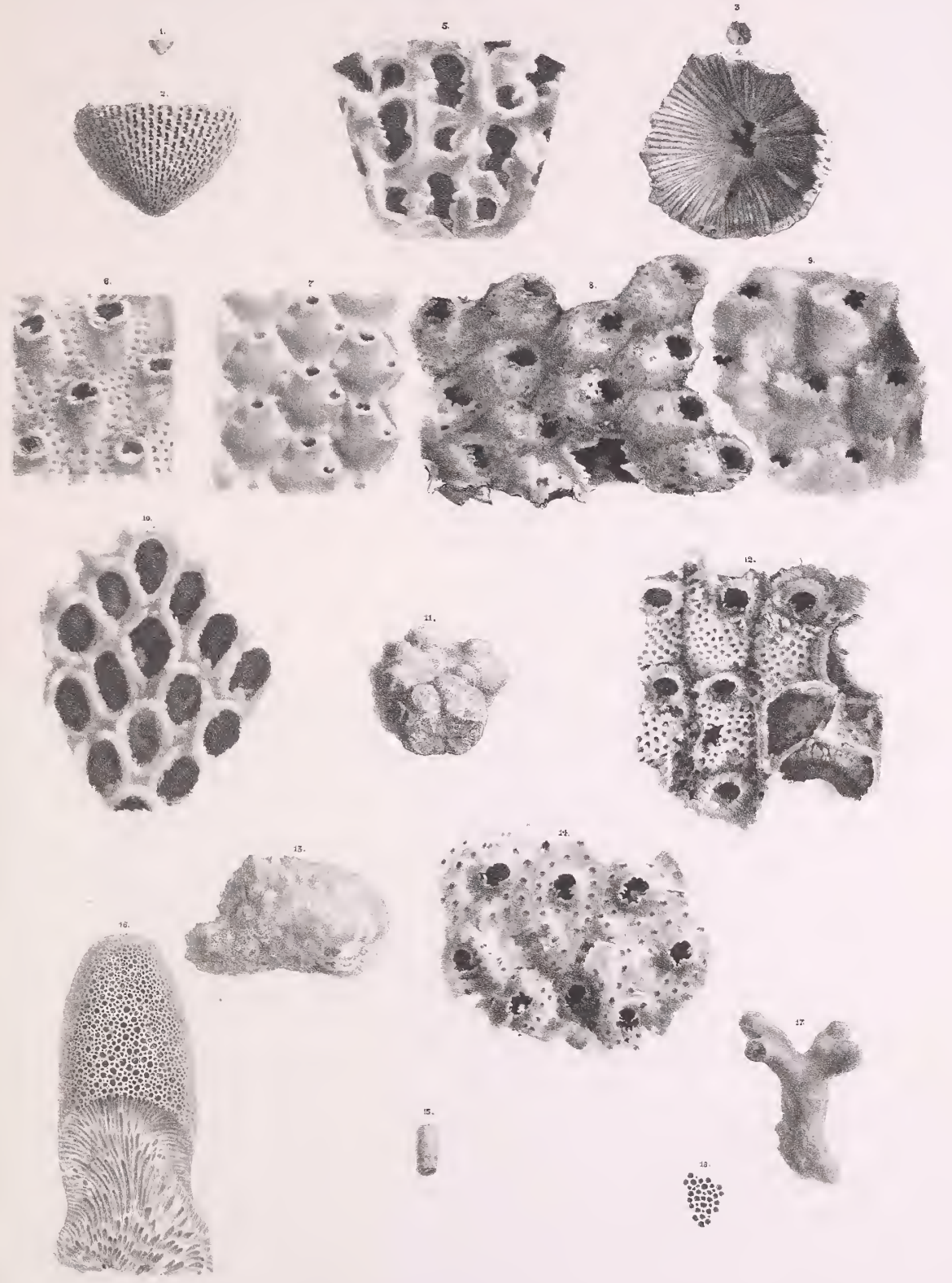






\title{
PLEIOCENE FOSSILS.
}

\author{
PLATE $\nabla$. \\ BRACHIOPODA.—ANOMIDE.—OSTRACID正.
}

BRA CHIOPODA.

Fig. 1. ORBICULA LUGUBRIS. Natural size. Page 17.

“ 2. ORBICUla MUltilineata. Natural size. Page 18.

" 3. ORBICULA LUGUBRIS. Young shell.

A NOMID As.

Fig. 4. ANOMIA EPHIPPIUM. Upper valve. Page 18.

" $5 . \quad$ " "

For PLACUNANOMIA of this family, see Plate VI., Figs. 4 to 6.

OSTRACID A.

Fig. 6. OSTREA VIRGINIANA. Fossil variety, resembling the recent Raccoon Oyster of the coast of South Carolina. Page 20.

" 7. Upper valve of fossil shell, same species, natural size.

"8. Lower valve of same.

"9. Side view of the same. 


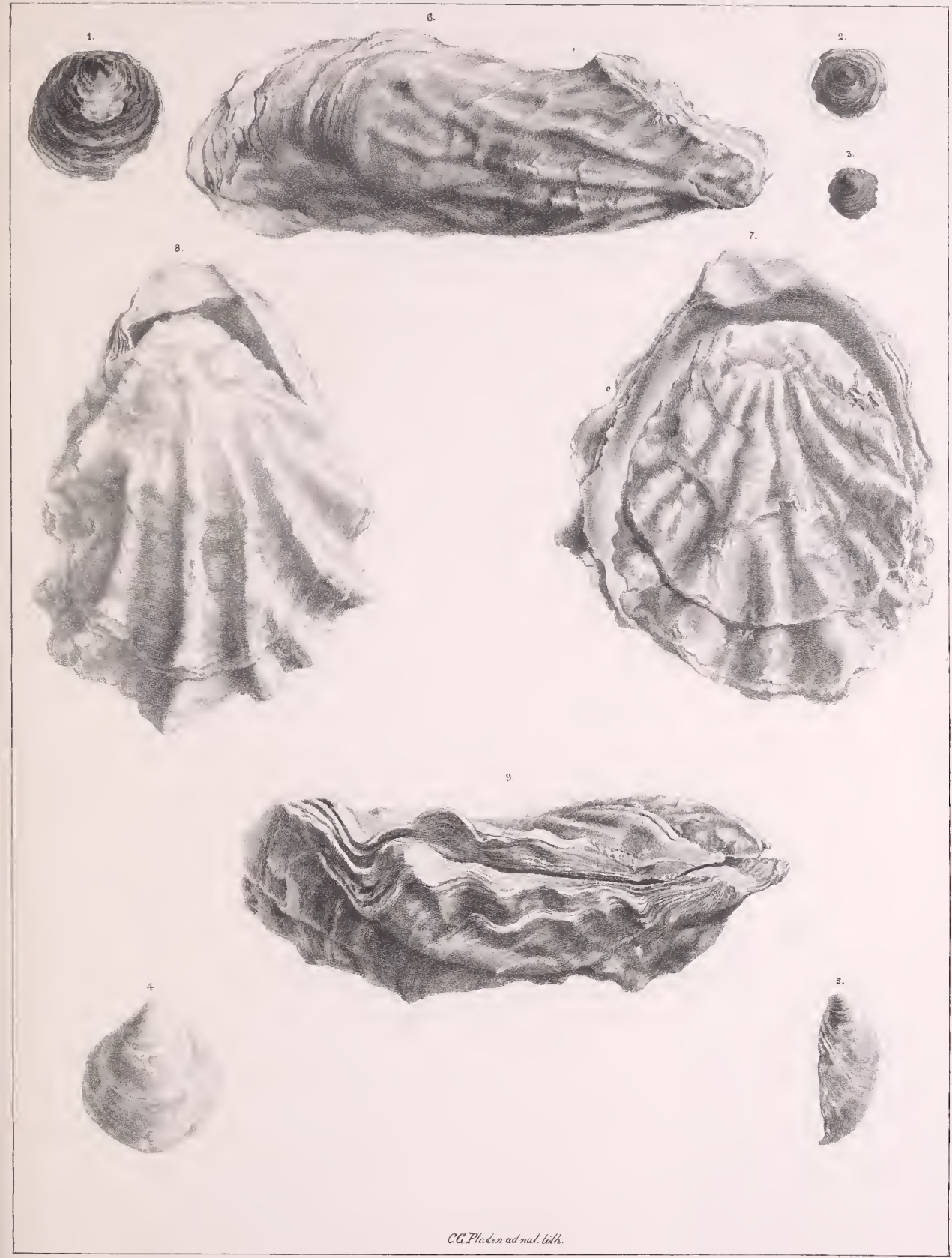






\section{PLEIOCENE FOSSILS.}

\section{PLATE VI.}

OSTRA CID E.—ANONID E.

OSTRACID $\mathbb{A}$.

Fig. 1. OSTREA RAVENELTANA. Upper view of fossil shell, natural size, showing the inequivalves. Page 21.

“ 2. Lower valve, natural size.

"3. Side view of the fossil.

\section{A N O MID A.}

Fig. 4. PLACUNANOMIA PIICATA. Upper valve, natural size. Page 19.

" 5. Interior of lower valve, showing the costal ribs of the hinge, the muscular impression, and the perforation for the passage of the organ of attachment.

"6. Side view of the fossil, natural size, showing the plicated margin. 
PI. 6.
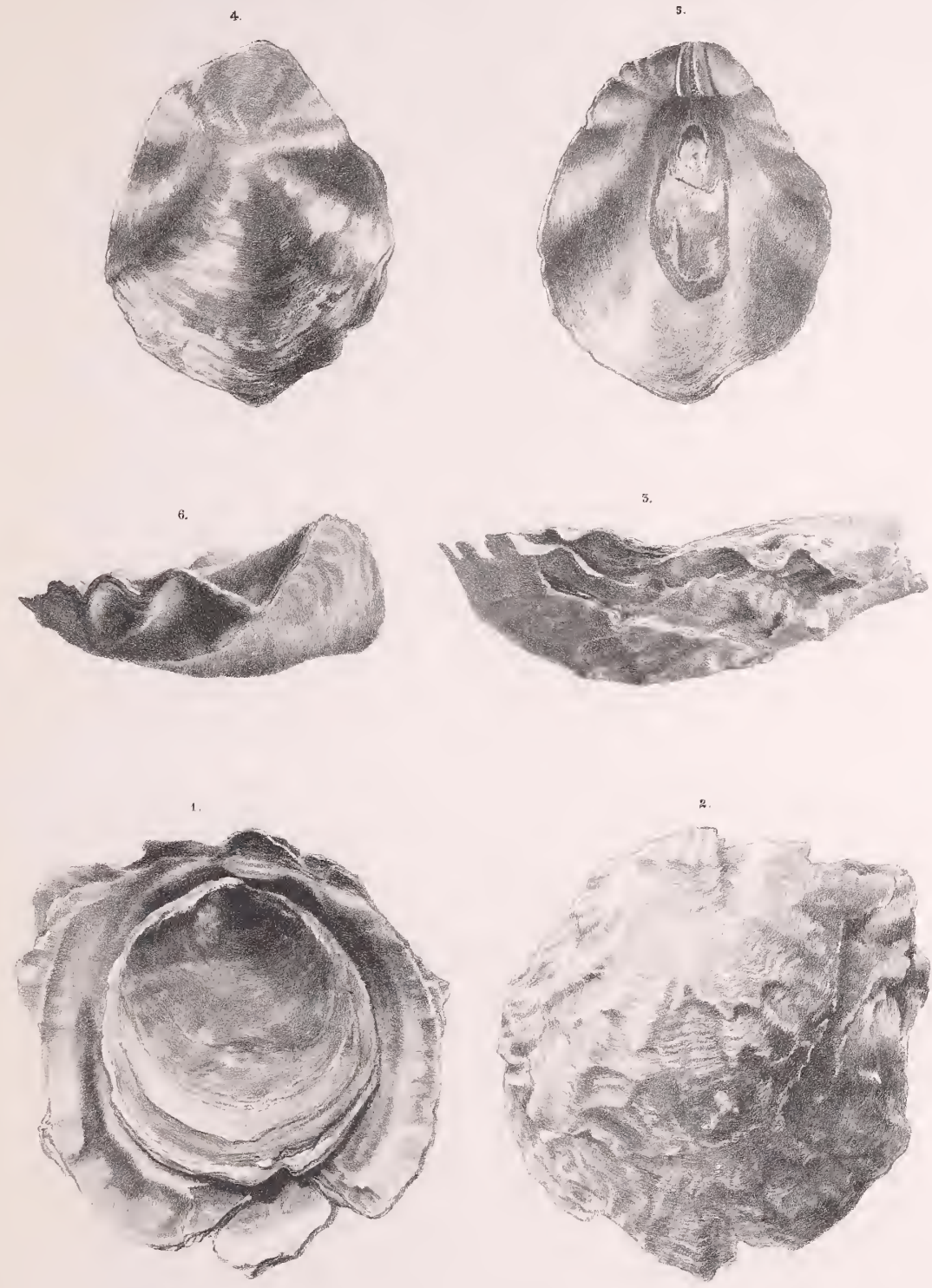



\section{PLEIOCENE FOSSILS.}

\section{PLATE VII}

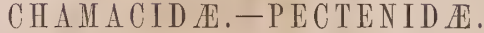

\section{CH A M A C I D $\mathbb{~}$.}

Fig. 1. CHAMA CORTICOSA. Lower valve, natural size. Page 22.

"2. View of fossil from above.

"3. Side view of the same.

"4. CHAMA ARCINELla. Side view. Page 22.

“ 5. View of interior of lower valve.

"6. View of lower valve.

"7. CHAMA CONGREgata. Upper view, natural size. Page 23.

" 8. Side view of the same.

"9. Interior of lower valve.

" 10. Interior of upper valve.

\section{PECTENID}

Fig. 11. Plicatula Marginata. Upper view of fossil, natural size. Page 24.

"12. Side view of the same.

" 13. Front view of the same, pallial margin.

"14. Interior of both valves. 

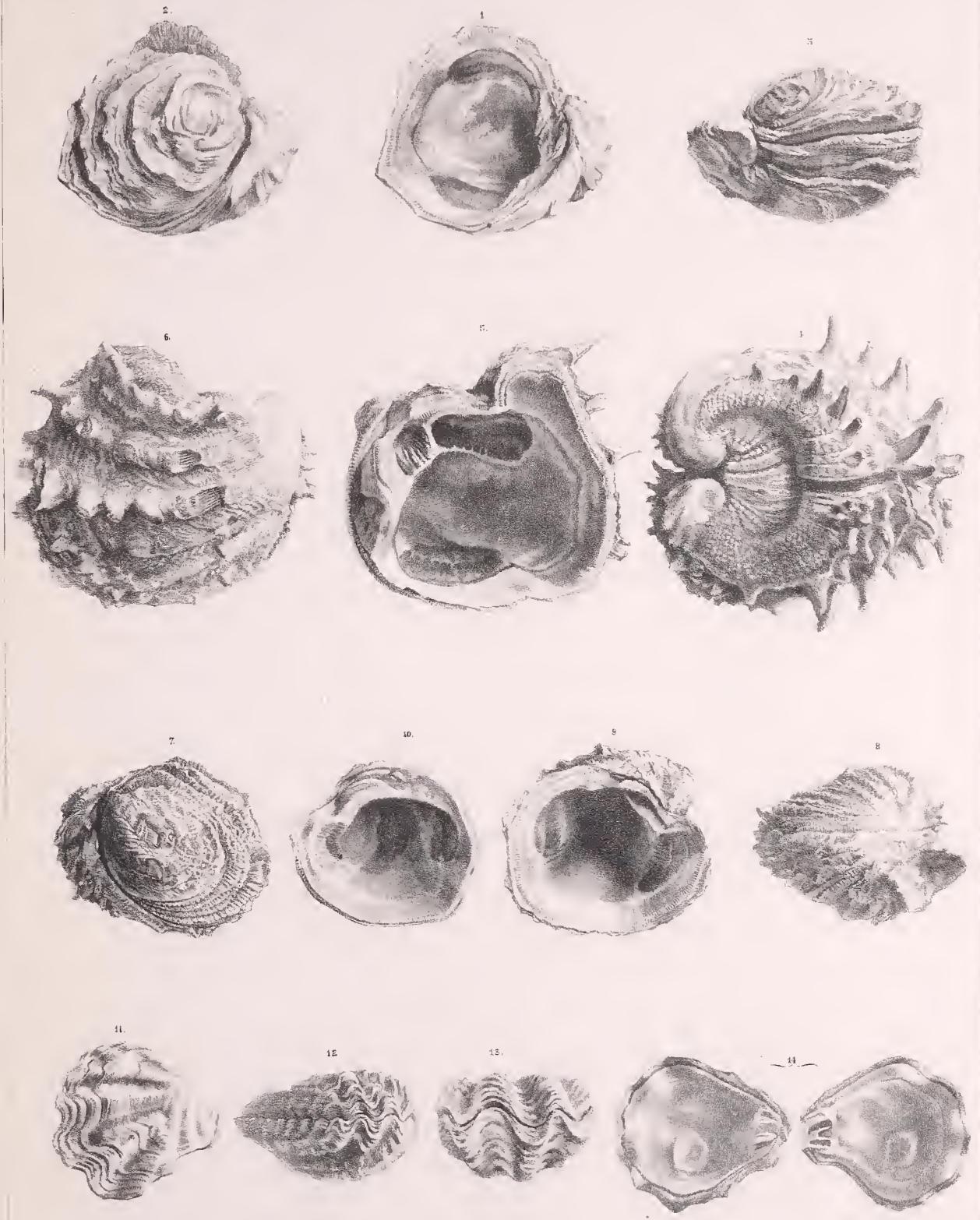

. 


\title{
PLEIOCENE FOSSILS.
}

PLATE VIII.

\author{
P E C T E N I D
}

Frg. 1. JANIRA HEMICYCLICA. Upper valve, natural size. Page 25.

“2. Lower valve.

"3. Side view of fossil.

"4. Outline of the ribs.

“ 5. JANIRA AFFINIS. Under side of lower valve, natural size. Page 26.

"6. Interior of same, to show the ribs on the margin. 
P1. 8.

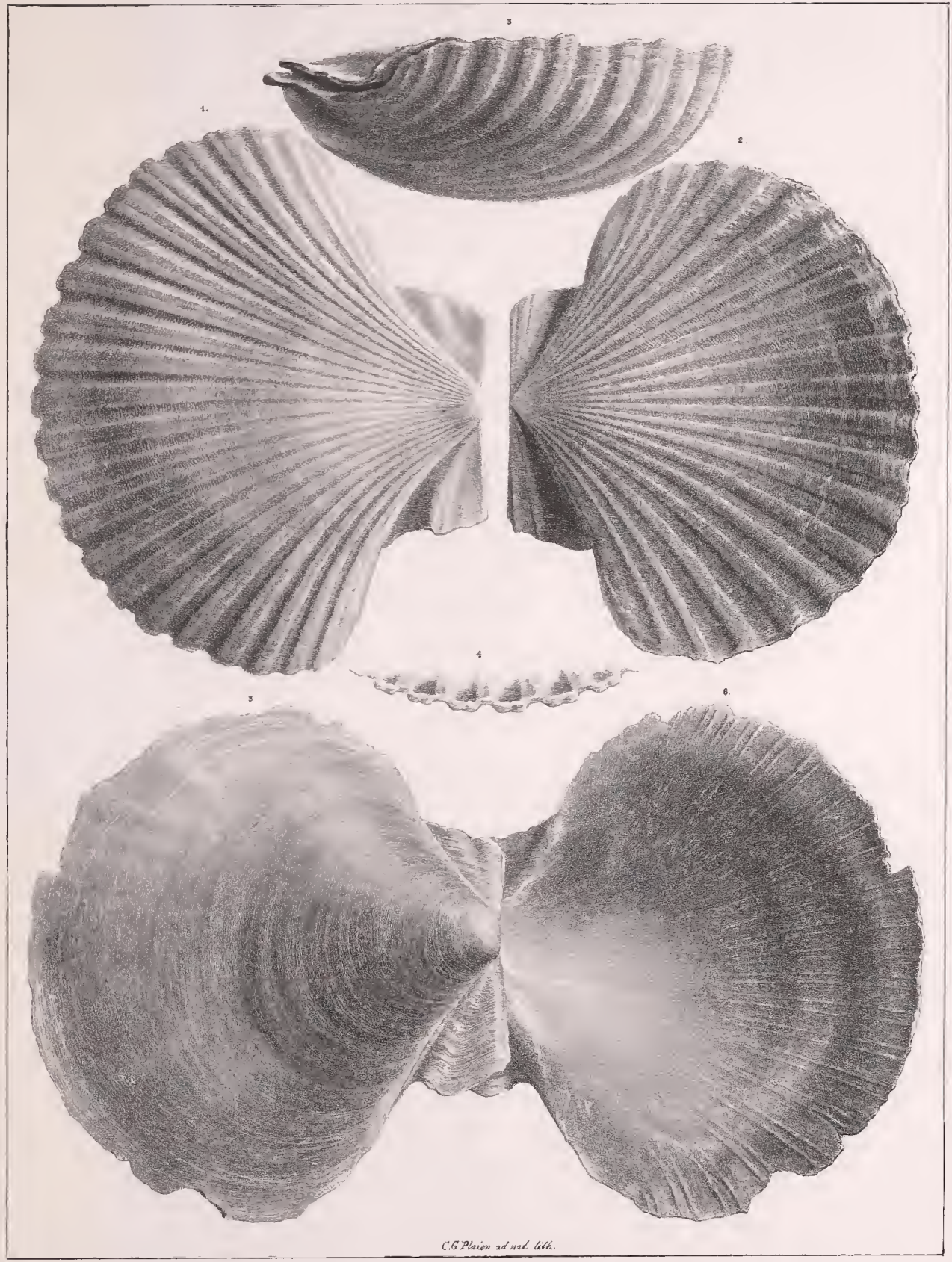






\section{PLEIOCENE FOSSILS.}

PLATE IX.

PECTEN I D $\mathbb{E}$.

Fra. 1. PECTEN MORTONI. Side view of shell, natural size. Page 27.

"2. Lower valve, natural size.

For a view of hinge and interior of lower valve, see Plate X., Figs. 1 and 2. 

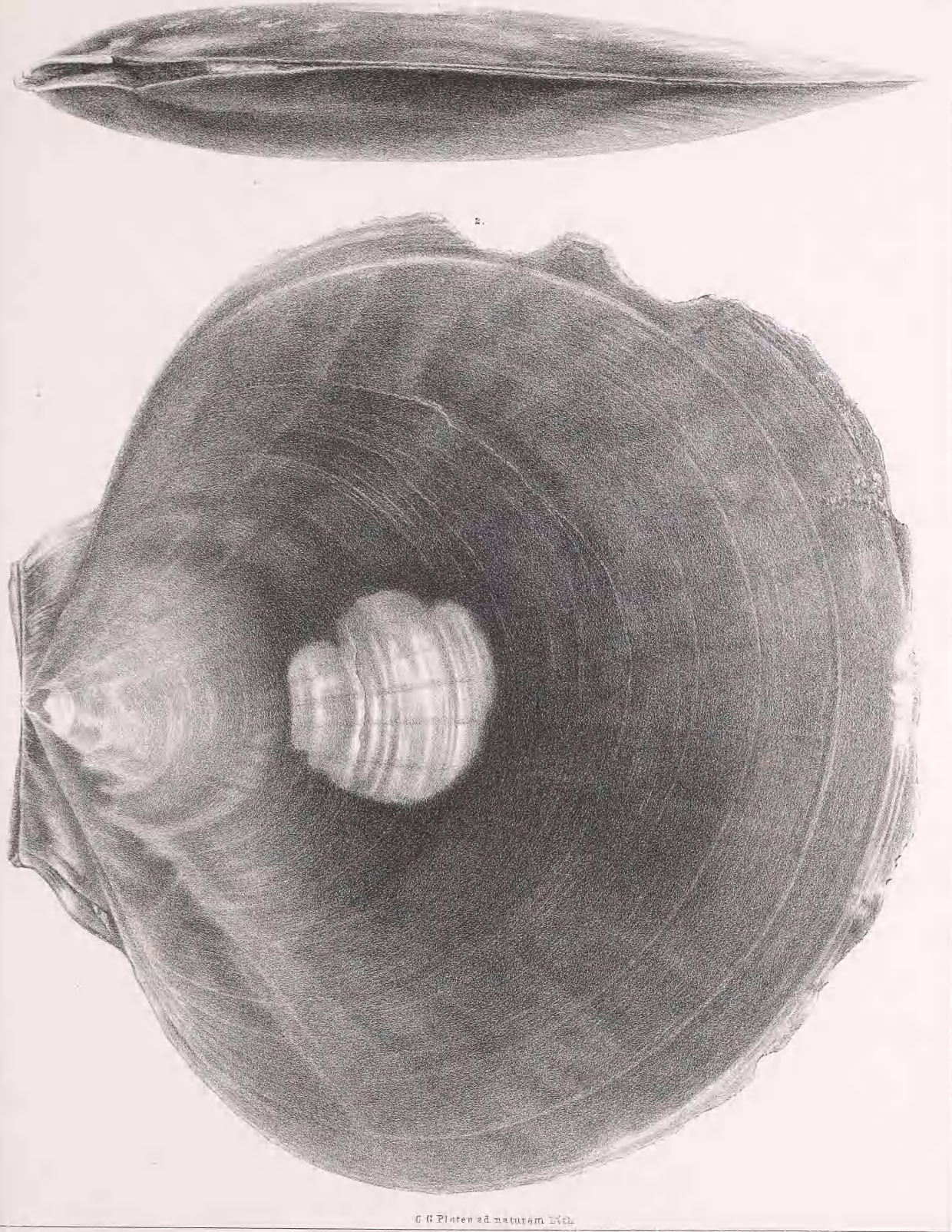



\title{
PLEIOCENE FOSSILS.
}

\author{
PLATE $X$.
}

P E C T E N I D $\mathbb{E}$.

Fra. 1. PECTEN MORTONI. End view of fossil, to show the hinge. Page 27.

"2. Interior of lower valve, to show the ribs.

For side view of this fossil, and exterior of valve, see Plate IX. 


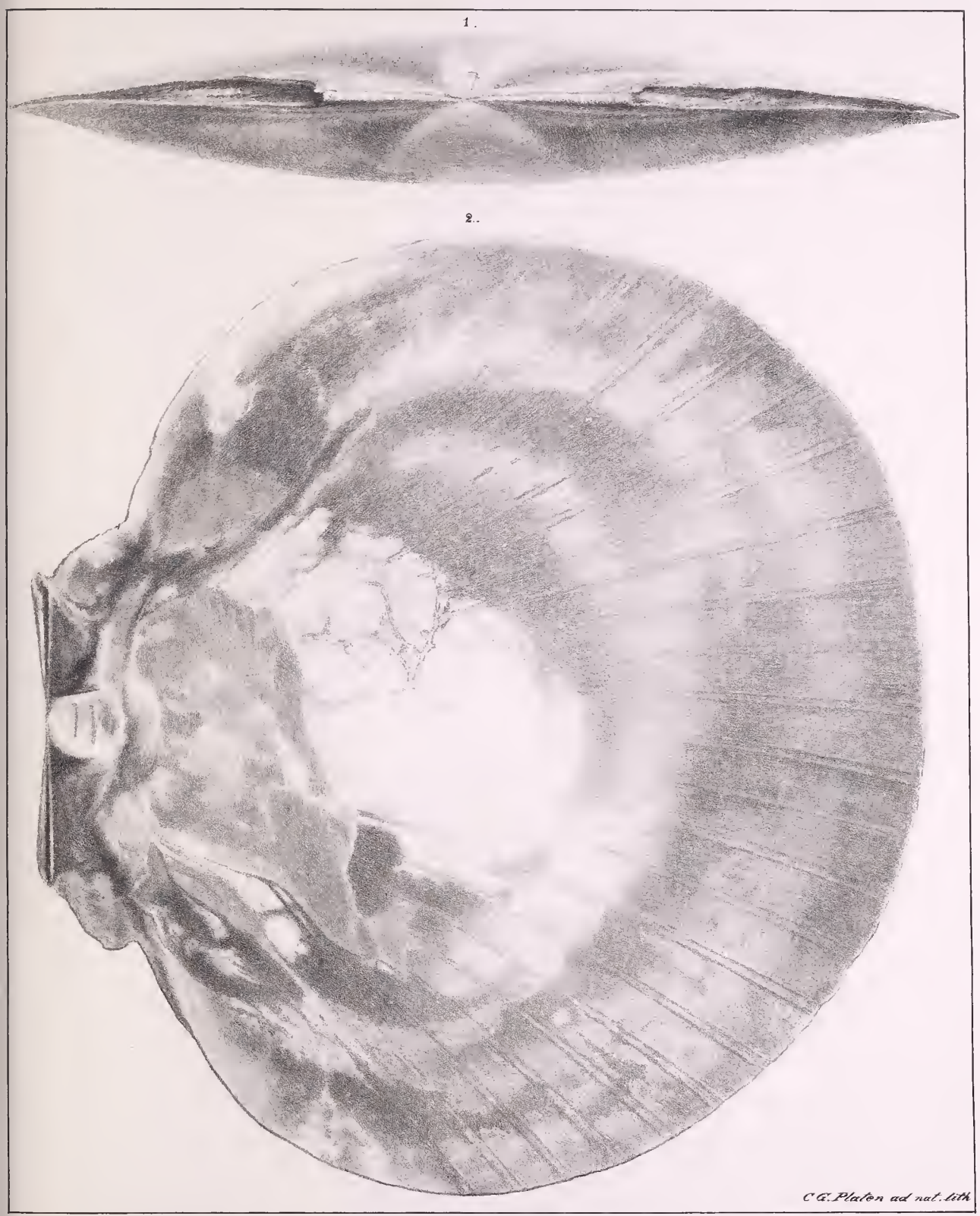





\section{PLEIOCENE FOSSILS.}

PLATE XI.

\section{P E C T E I D $\mathrm{E}$.}

Fig. 1. PECTEN EBOREUS. Upper valve, natural size. Page 28.

"2. Lower valve.

"3. Side view of fossil.

"4. Outline of the ribs.

"5. Magnified view of a section of the ribs and interstices, showing the concentric undulating lines.

“ 6. PEOTEN COMPARILIS. Upper valve. Page 29.

"7. Lower valve.

" 8. Side view of fossil, natural size.

" 9. Outline of ribs.

"10. Magnified view of a section of the ribs and interstices, showing the concentric undulating lines. 

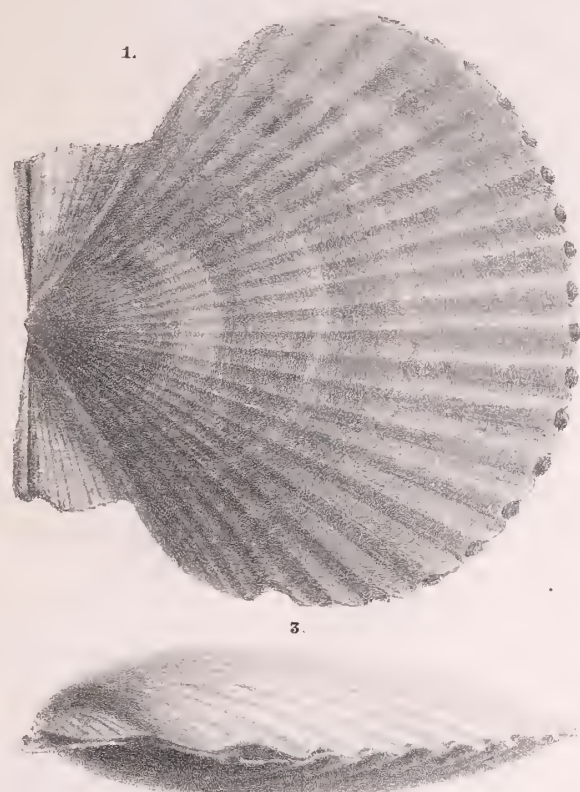

8
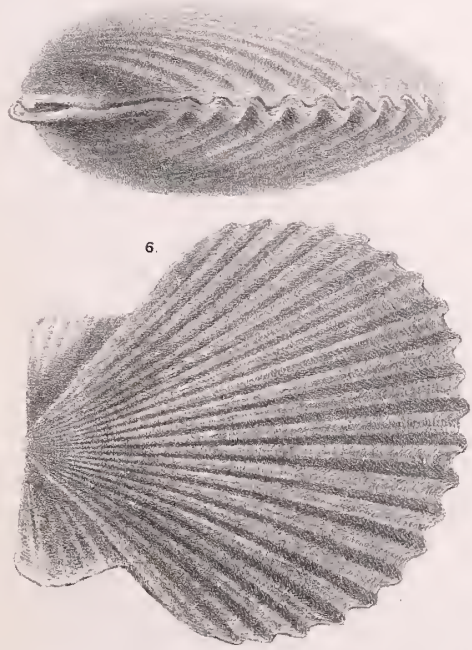

2.

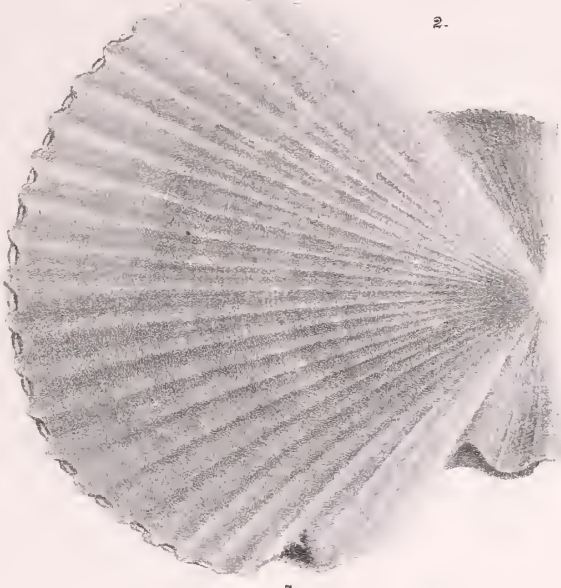

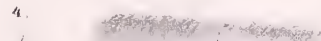

$\left\{1+1+\frac{1}{1}\right.$

if and as

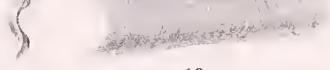

9. 10.

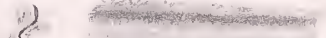

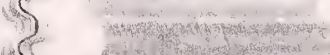

14 (1)

15

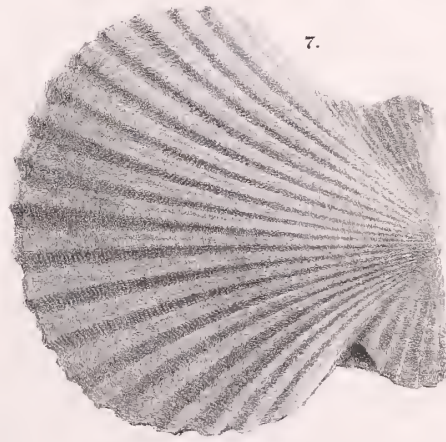

C. Platen od nat. lith. 




\section{PLEIOCENE FOSSILS.}

PLATE XII.

P E C T E I D E.

Fig. 1. PEOTEN PEEDEENSIS. Upper valve, natural size. Page 30.

“ 2. Lower valve.

"3. Side view of fossil.

"4. Outline of the form of the ribs.

" 5. Magnified view of a portion of a rib, showing the radiating and transverse strix. 


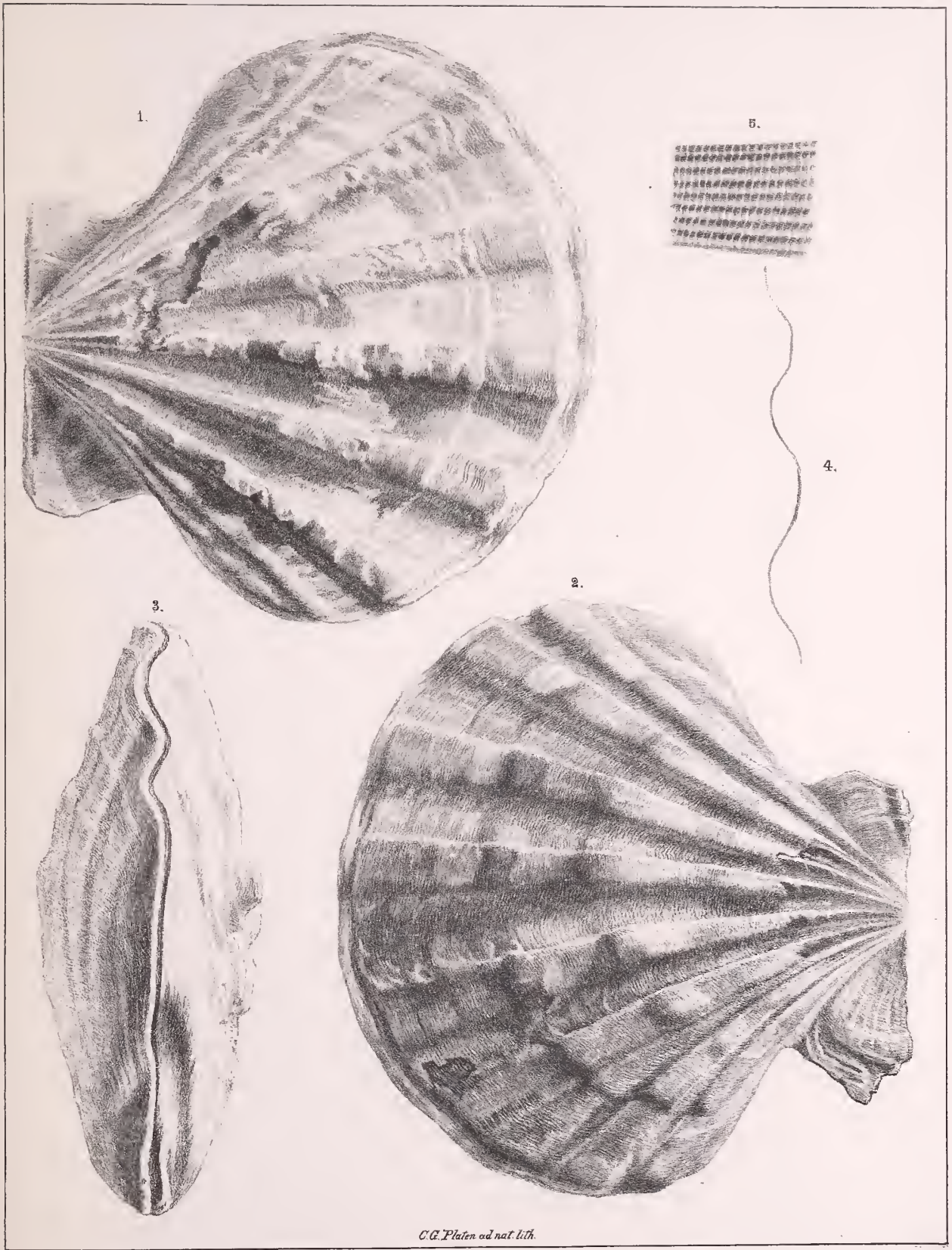






\section{PLEIOCENE FOSSILS.}

PLATE XIII.

\section{P E C T ENID $A$.}

Fig. 1. PEOTEN SEPTENARIUS. Lower valve natural size. Page 31.

"2. Side view of Fossil.

"3. Magnified view of a portion of a rib.

.64 4. Outline of the form of the ribs at margin. 
3.
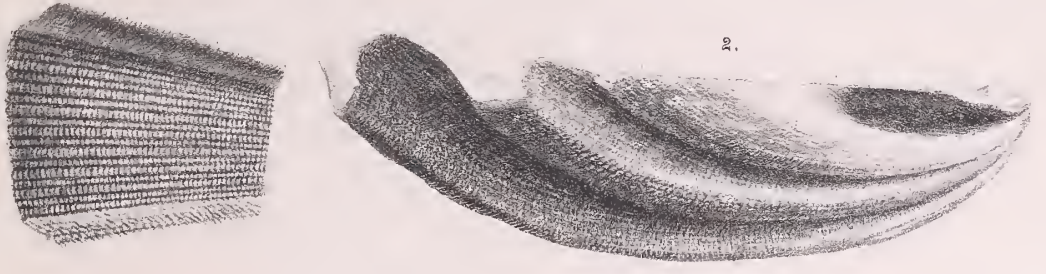

1.
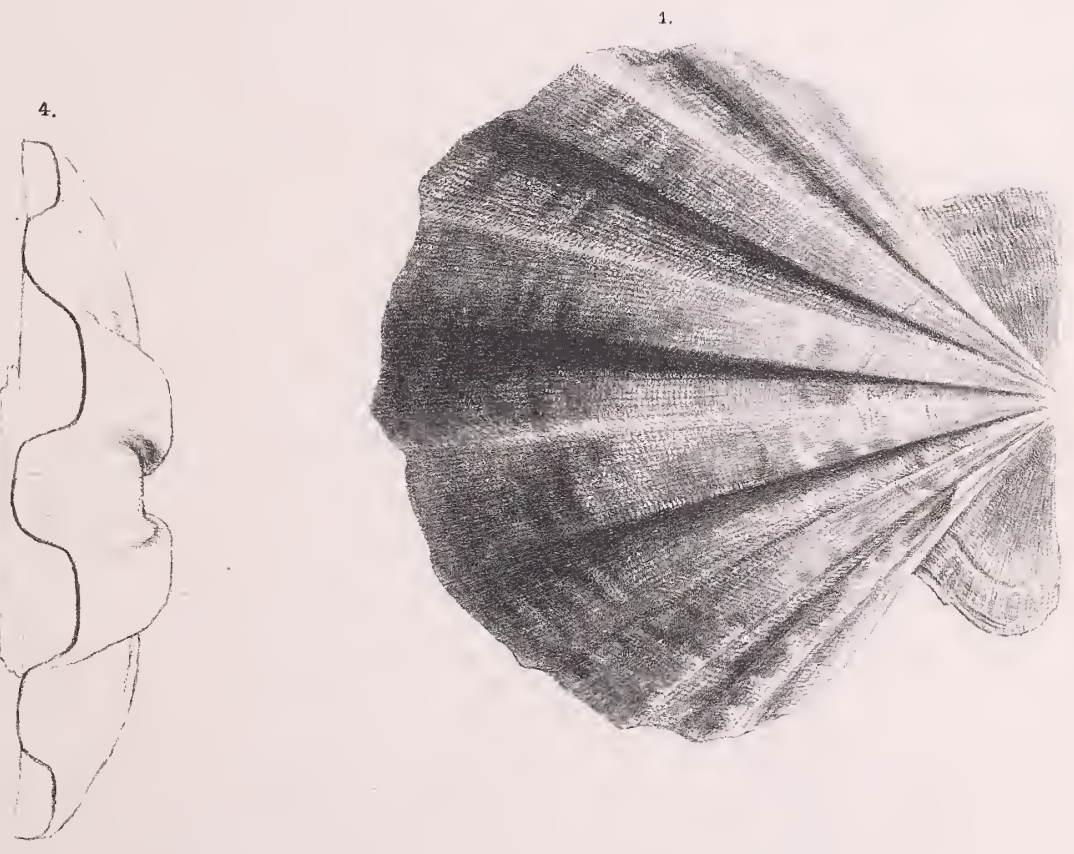




\section{PLEIOCENE FOSSILS.}

PLATE XIV.

M Y T I L I D $\mathbb{E}-\mathrm{A}$ R C A C I D $\mathbb{E}$.

Fig. 1. MYTLLUS INCRASSATUS. Exterior of shell natural size. Page 32.

"2. Interior of the same.

“ 3. MYTILUS INFLATUS. Interior of shell, natural size, imbedded in marl. Page 33.

$$
\text { A R C A CID } \mathbb{E} \text {. }
$$

“ 4. ARCA HIANS. Exterior of upper valve and hinge, and teeth of lower valve, natural size. Page 34 .

“5. Pallial margin to show gaping.

“6. ARCA INCILE. Exterior of upper and interior of lower valve natural size. Page 35.

"7. End view of same to show hinge.

“ 8. ARCA CALLATA. Exterior of shell, natural size. Page 36.

"9. Interior of shell.

"10. Magnified view of the strix, showing nodulous ribs.

“ 11. ARCA CENTENARIA. Exterior of upper and interior of lower valve, natural size. Page 37.

" 12. Side view of fossil. 


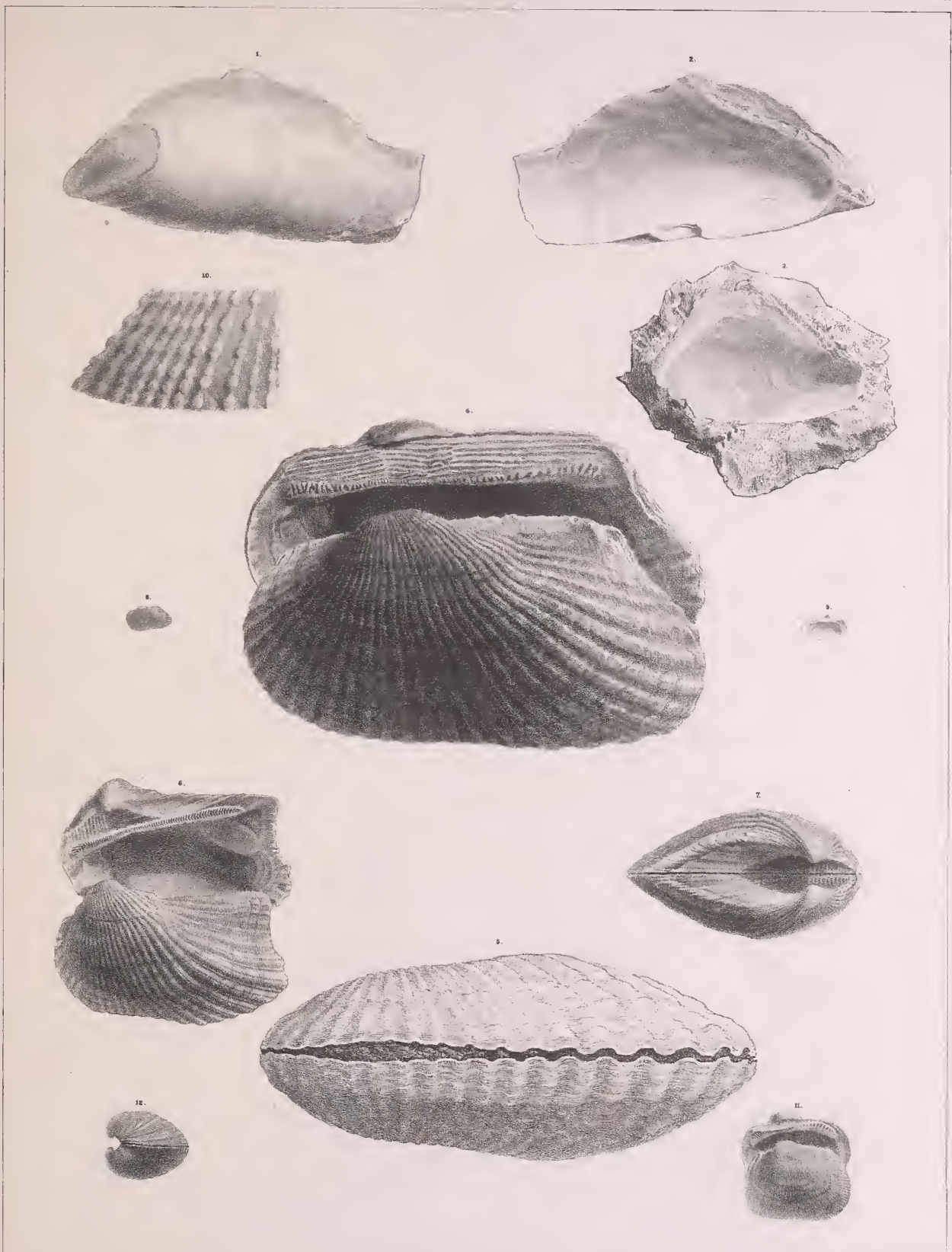

C. G. Platen ud nit Wilb. Contestion S.C. 



\title{
PLEIOCENE FOSSILS.
}

\author{
PLATE XV.
}

\section{A R C A CID E.}

Fig. 1. ARCA RUSTICA. Fragment of the only specimen in our possession. The outline is correct. Page 39.

" 2. ARCA LIENOSA. Exterior of left valve, and hinge and teeth of right valve. Page 40.

“ 3. End view, showing outline of hinge and umbones.

“ 4. ARCA IMPROCERA. Exterior of left valve, and hinge and teeth of right valve. Page 41.

“5. End view, shewing outline, hinge and umbones.

" 6. ARCA TRANSVERSA. Exterior of left valve, and hinge and teeth of right valve, Page 42.

" 7 . End view, showing outline of hinge and umbones. 




\section{PLEIOCENE FOSSILS.}

PLATE XVI.

\section{A R C A C I D}

Fig. 1. ARCA SCALARIS. Exterior of left valve, and hinge and teeth of right valve. Page 43.

“ 2. End view, showing outline of hinge and umbones.

“ 3. ARCA EQUICOSTATA. Exterior of left valve, and hinge and teeth of right valve. Page 44.

"4. End view, showing outline hinge and umbones.

“ 5. ARCA INCONGRUA. Exterior of left valve, and hinge and teeth of right valve. Page 45.

"6. End view, showing outline, hinge and umbones.

" 7. ARCA PEXATA. Exterior of left valve, and hinge and teeth of right valve. Page 46.

“ 8. End view, showing hinge and umbones. 


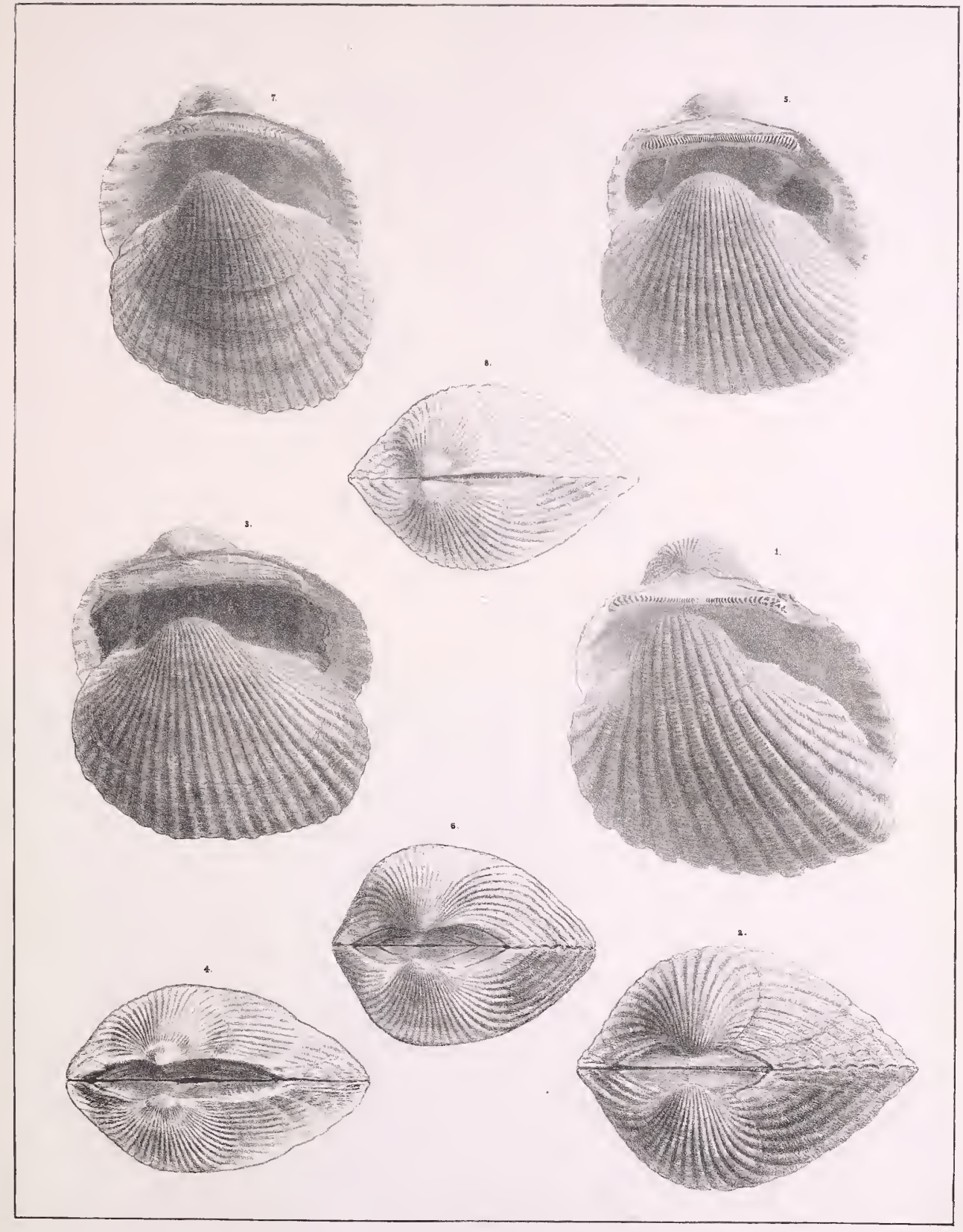





\section{PLEIOCENE FOSSILS.}

PLATE XVII.

A R C A C I D E. - N UCULID E.

A R C A C I D E.

Fig, 1. PECTUNCULUS SUBOVATUS. Interior of right and exterior of left valve, natural size. Page 47.

"2. PEGTUNCULUS LANTIFORMIS. Same views. Page 48.

“ 3. PECTUNCULUS PASSUS. Same views. Page 48.

“ 4. PECTUNCUldS QUINQUERUGATUS. Same views. Page 49.

“ 5. PEUTUNCULUS LAivis. Same views. Page 50.

“ 6a. PECTUNCULUS ARATUS. Interior, natural size. Page 50.

"6b. Exterior, natural size.

"6. A large variety of the same.

“ 6c. PECTUNCULUS TRANSVERSUS. (A natural cast.) Page 51.

N U C U L I D $\$$.

Fig. 7. NUCULA PROXIMA. Interior of right valve, natural size. Page 53.

" 8. Exterior of left valve.

“9. Magnified view of hinge and teeth.

" 10. NUCULA ACUTA. Exterior, natural size. Page 53.

" 11. Interior, natural size.

" 12. Magnified view of hinge and teeth.

" 13. NUCUla Limatula. Exterior, natural size. Page 52.

" 14. Interior, natural size.

" 15. Magnified view of hinge and teeth. 



\title{
PLEIOCENE FOSSILS.
}

\author{
PLATE XVIII.
}

\section{U C I N I D E.}

Fig. 1. LUCINA CONTRACTA. Interior of right and exterior of left valve, natural size. Page 54.

"2. LUCINA ANADONTA. Same views. Page 55.

“ 3. LUCINA PENNSYLTANICA. Same views. Page 56.

“4. LUCINA RADIANS. Interior of right valve. Page 57.

“5. Exterior of left valve. In figure 5 the artist has not succeeded in exhibiting the delicate radiating lines, which are generally well-defined in good specimens.

“6. LUCINA SQUAMOSA. Interior of right vaive. Page 57.

“7. Extcrior of left valve.

“ 8. LUCINA CRIBRARIA. Interior of right valve. Page 58.

“9. Exterior of left valve.

" 10. LUCINA DIVARICATA. Interior of right valve. Page 59.

"11. Exterior of left valve.

" 12. LUCINA COSTATA. Natural size. Page 60.

"13. The same magnified.

“ 14. LUCINA CRENULATA. Natural size. Page 60.

" 15 . The same magnified.

“ 16. LUCrNa MULTILINEATA. Natural size. Page 61.

"17. The same magnified.

“ 18. LUCINA TRISUlCATA. Page 62.

"19. The same magnified. 
Pl.18.
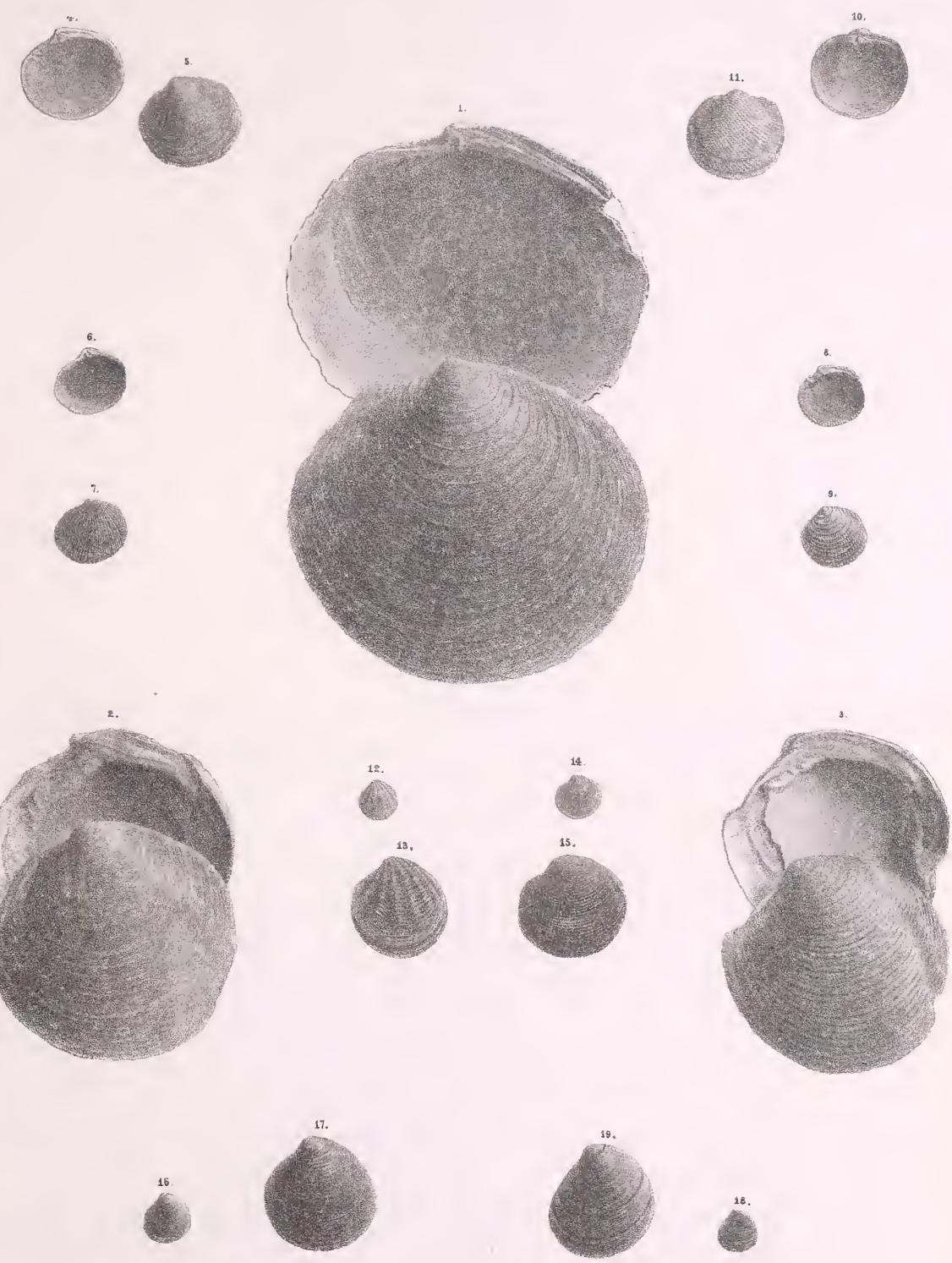




\section{PLEIOCENE FOSSILS.}

PLATE XIX.

CARDIDE.-CARDITIDE.

C A R D I D $\mathscr{A}$.

Fig. 1. CARDIUM MAgNUM. Natural size. Page 63.

“ 2 CARDIUM MURICATUM. Interior of right and exterior of left valve, natural size. Page 64.

“ 3. CARDIUM SUbLINEATUM. Same views. Page 64.

$$
\text { C A R D I T I E. }
$$

Fig. 4. CARDita ARATét. Exterior of left valve. Page 65.

“ 5. Interior of right valve, natural size.

7 “6. CARDITA GRANULATA. Interior of right valve. Page 66.

"7. Exterior of left valve, natural size.

“ 8. CARDITA TRIDENTATA. Interior of right valve. Page 67.

( “ 9. Exterior of left valve, natural size.

“ 10. CARDITA CARINATA. Interior of right and exterior of left valve, natural size. Page 67.

“ 11. CARDITA PERPLANA. Natural size. Fage 68.

“ 12. CARDITA ABBreviatA. Natural size. Page 69. 


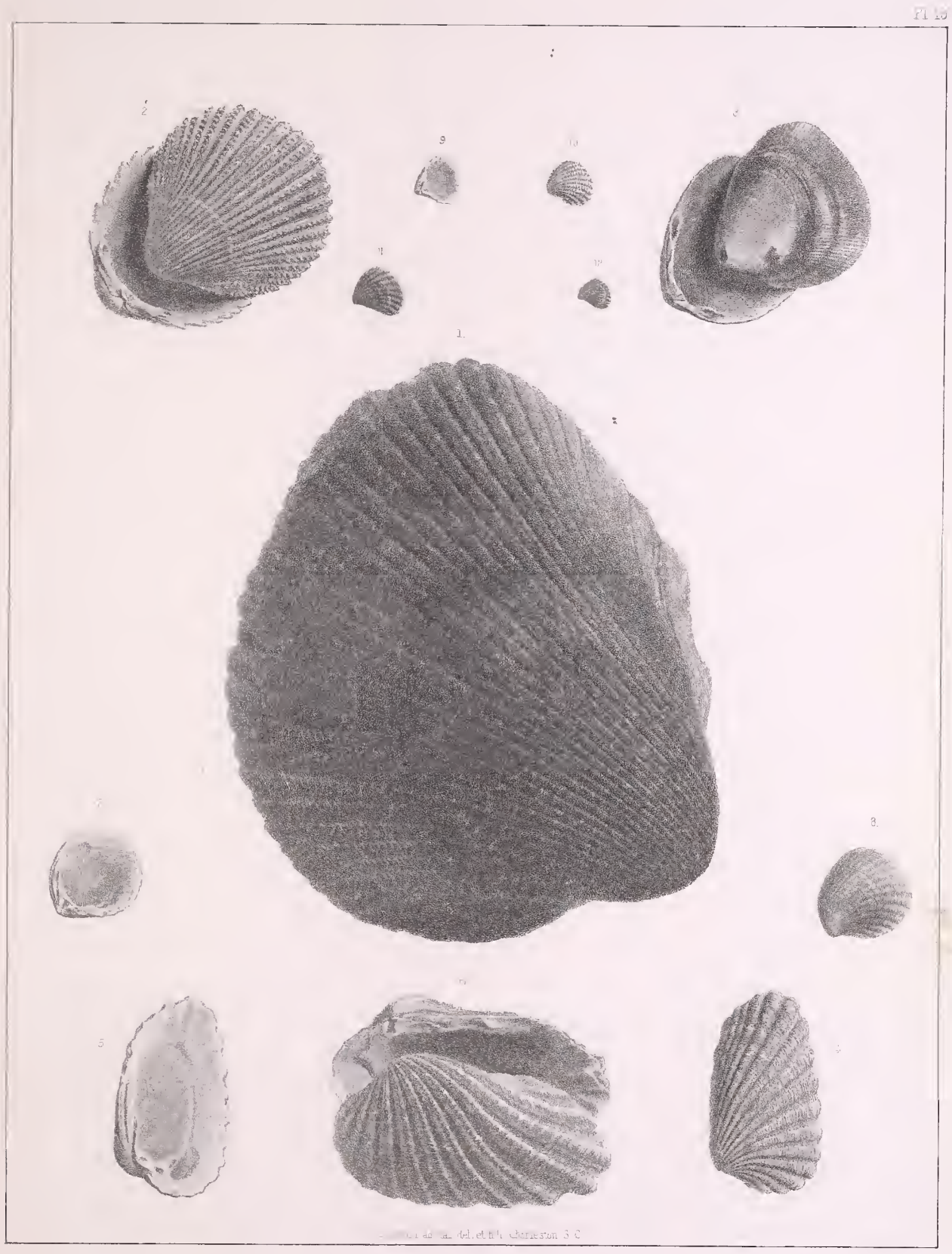






\section{PLEIOCENE FOSSILS.}

PLATE XX.

ASTARTIDE.-CORBULID A.-CYCIASID E.

A S T A R T I D A.

Fig. 1. ASTARTE UNDUlatA. Common variety, natural size. Page 70.

"2. Another variety, natural size.

“ 3. ASTARTE CONCENTRICA. Interior of right and exterior of left valve, natural size. Page 71.

“ 4. ASTARTE LUNUlata. Natural size. Page 72.

“ 5. CRASSATELla UNDULATA. Interior of right valve, natural size. Page 73.

"6. Exterior of right valve, natural size.

"7. Young shell, natural size.

“ S. Variety of Crassatelia undulata, natural size.

“ 9. CRASSATELLA GIBBESII. Exterior of left valve, natural size. Page 74.

"10. Young shell.

\section{O R B U L I D A}

Fig. 11. CORBUla CUNEATA. Natural size. Page 75.

“ 12. CORBULA INEQUALE. Natural size. Page 76.

“ 13. PANDORA TRILINEATA. Natnral size. Page 76.

C Y C L A S I D A.

Frg. 14. CYRENA DENSATA. Interior of right and exterior of left valve, natural size. Page 77. 


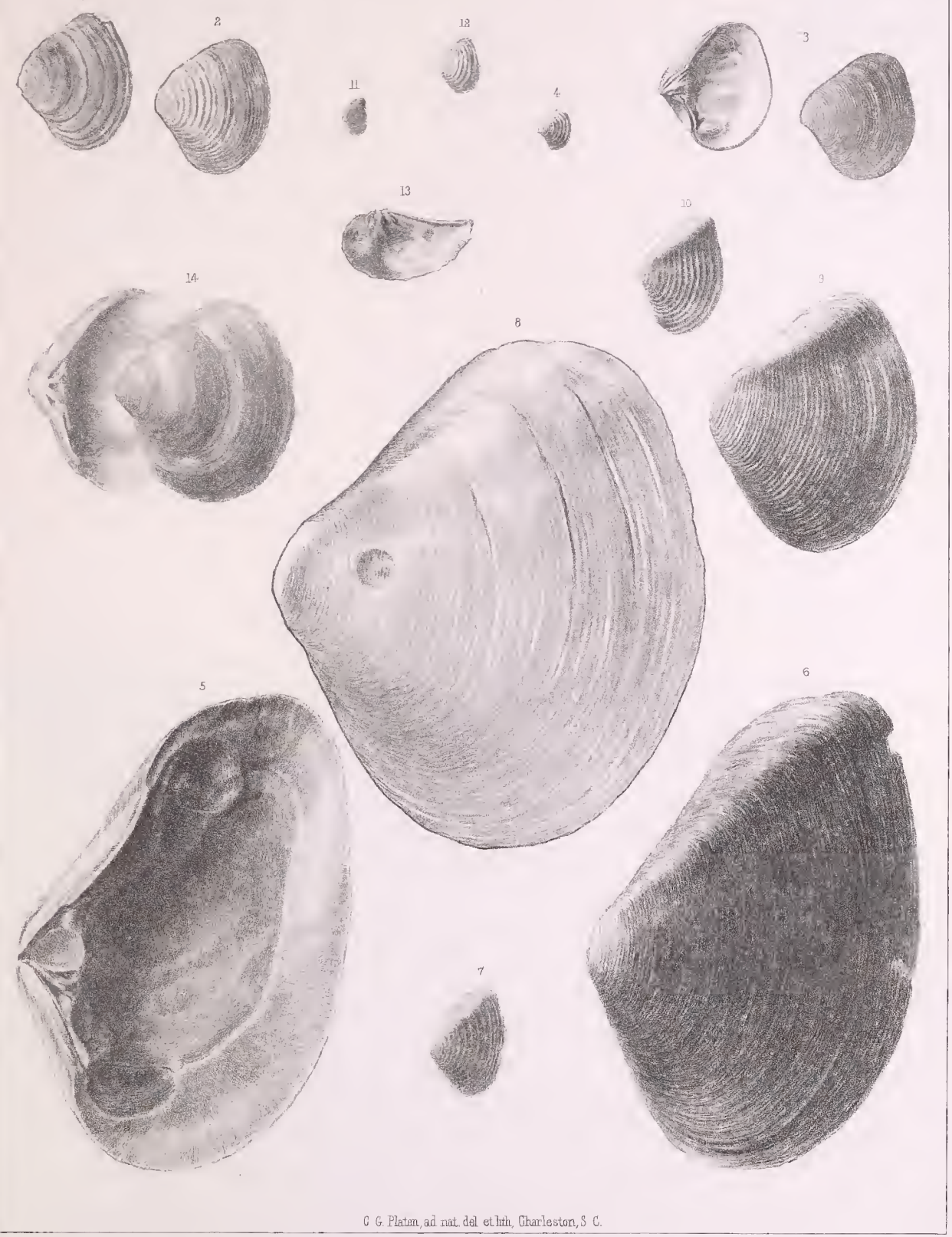






\section{PLEIOCENE FOSSILS.}

PLATE XXI.

V E N E R I D E.

Fig. 1. VenUs metastriata. Natural size. Page 79.

" 2. Outline of another variety, natural size, with a magnified figure.

“ 3. VENUS SUBNASUTA. Outline natural size, with magnified figure. Page 80.

“4. VENUS REPOSTA. Natural size. Page 80.

“ 5. PETRICOLA PHOLADIFORMIS. Natural size. Puge 87.

“6. VenUs MERCENARIA. Natural size. Page 81.

“7. Venus CONCENTRICA. Natural size. Puge 82.

“ 8. VENUS RYLEYII. Natural size. Page 78.

“9. VENUS SAYANA. Natural size. Page 83.

" 10. VENUS CRIBRARIA. Natural size. Page 83.

“ 11. VENUS CANCELlata. Natural size. Page 84

“ 12. VENUS LATILIRATA. Natural size. Page 85. 


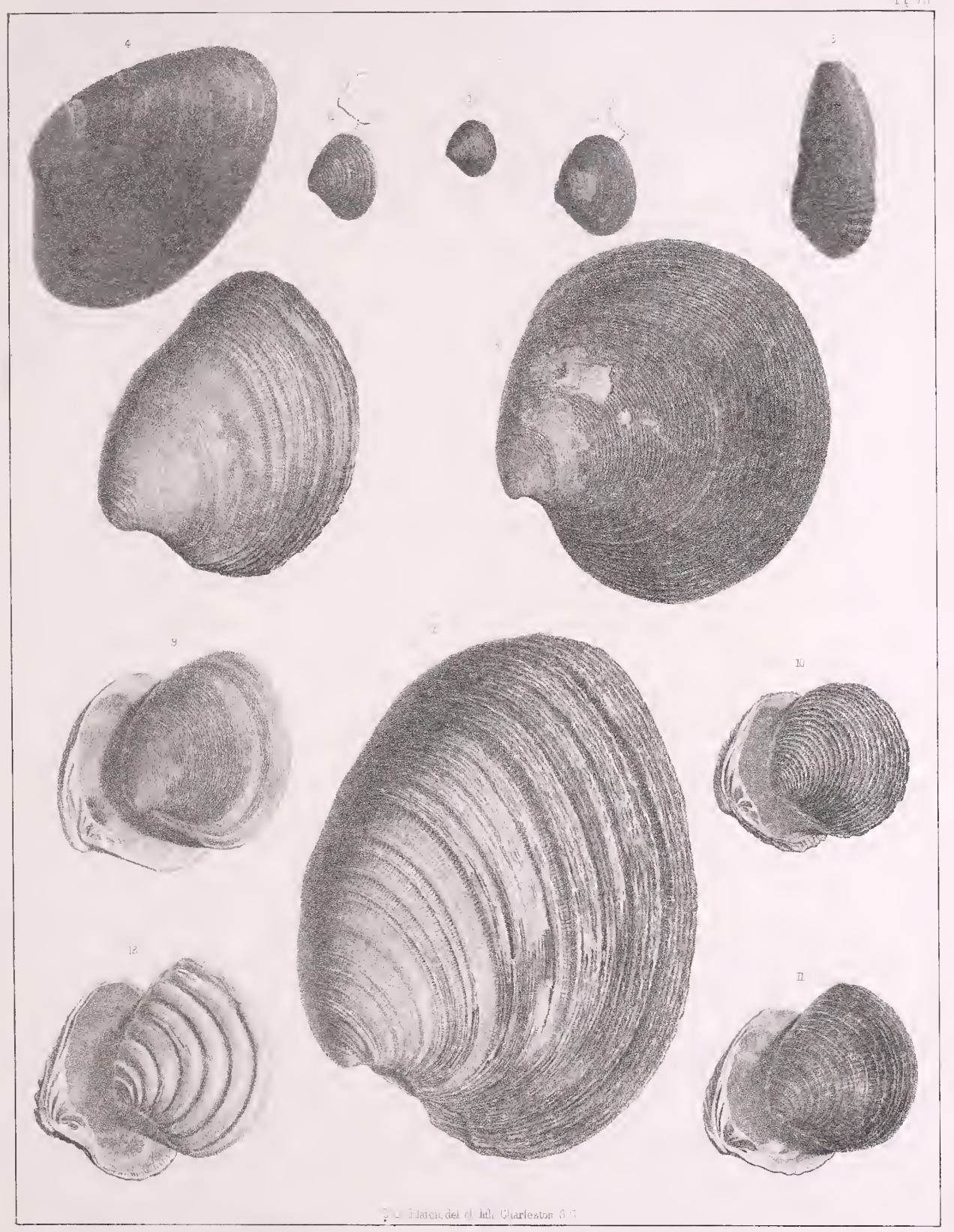






\section{PLEIOCENE FOSSILS.}

PLATE XXII.

V E N E R I D E. 一 T E L L I N I D Æ.

VENERID开.

Fig. 1. VenUS TRIDACNOIDes. Natural size, Page 85.

“ 2. VENUS PERMAGNA. Natural size. Page 86.

T ELLINID 开.

F1G. 3. TELlina BIPLiCATA. Natural size. Page 88.

" $3 a$. End view of the same.

“ 4. Tellina alternata. Natural size. Page 89.

“ 5. TEllina lUSORIA. Page 89.

“6. TEllina POLita. Page 91.

“7. TELLina FleXUOSA. Magnified to show the oblique lines. Page 90.

“ $7 a$. Interior of the same, natural size.

" 7 . Exterior of the same, natural size.

“ 8. PSammacola Pleiocena. Natural size. Page 91. 
PL. 22.

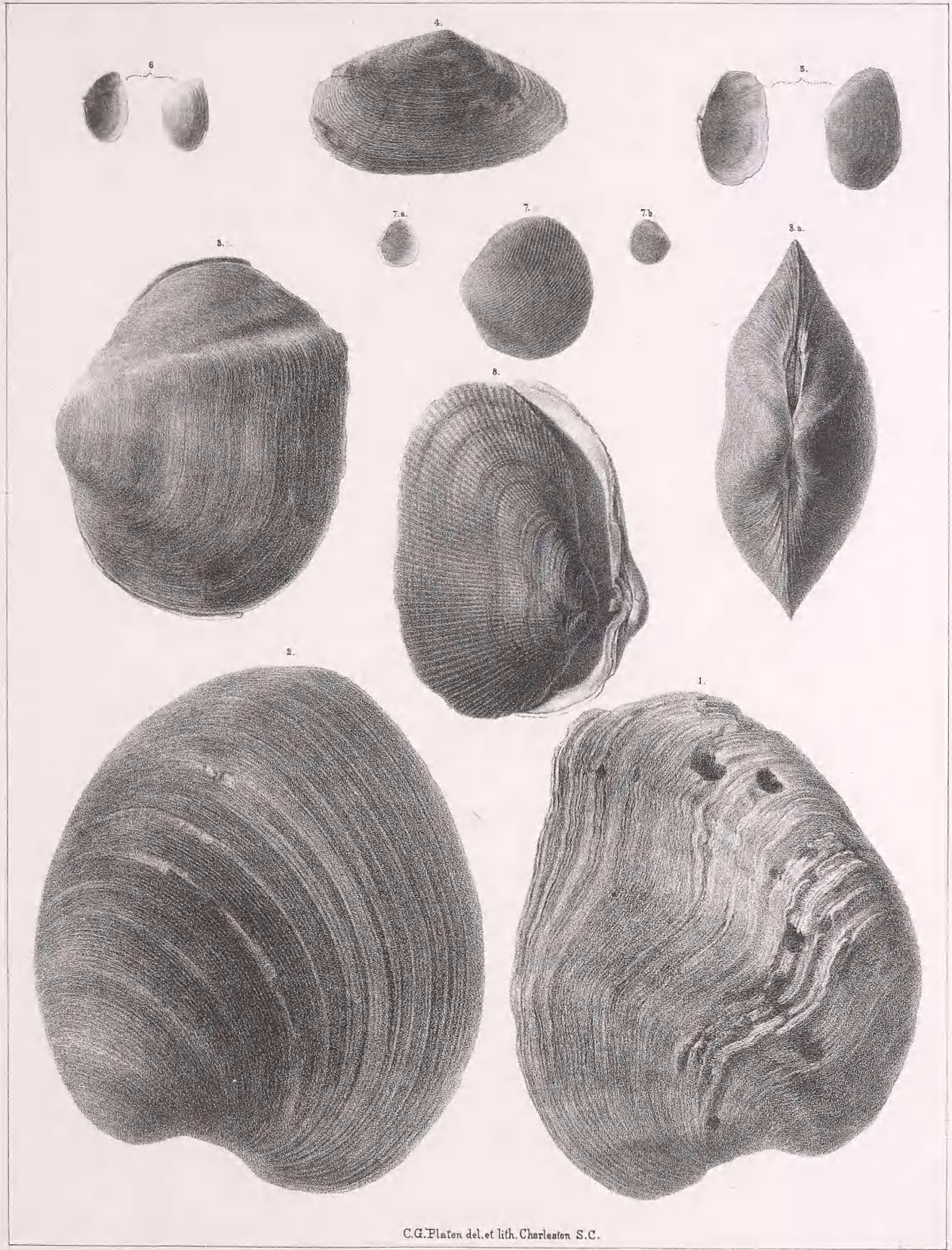






\section{PLEIOCENE FOSSILS.}

PLATE XXIII.

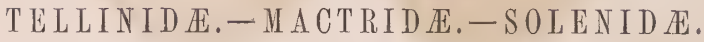

T E L L I N I D $\mathbb{\text { A. }}$.

Fig. 1. LAVIGNON TELLINOIDES. Interior and exterior, natural size. Page 92.

“ 2. SINODESMIA CARINATA. Interior and exterior, natural size. Page 93.

“ 3. AMPHIDESMA EQUALIS. Exterior, natural size. Page 93.

“ 4. AMPHIDESMA ORBICULATA. Intcrior and exterior, natural size. Page 94.

“5. AMPHIDESMA EQUATA. Imperfect specimen, natural size. Page 95.

“6. DONAX VARIABILIS. Natural size. Page 95.

\section{A C T R I D $A$.}

Fig. 7. MACTRA OBLONGata. Natural size. Page 96.

“ 8. MACTRA SIMILIS. Natural size. Page 97.

“ 9. MACTRA LATERALIS. Interior and exterior, natural size. Page 97.

"10. MACTRA CONGESTA. Natural size. Page 98.

" 11. GNATHODON GRAYII. Natural size. Page 99.

$$
\text { S OLE N I D }
$$

F1G. 12. SOLECURTUS CARIB(EUS. Exterior of shell. Page 99.

"13. Interior of the same, natural sizc. 
Pl. 28.
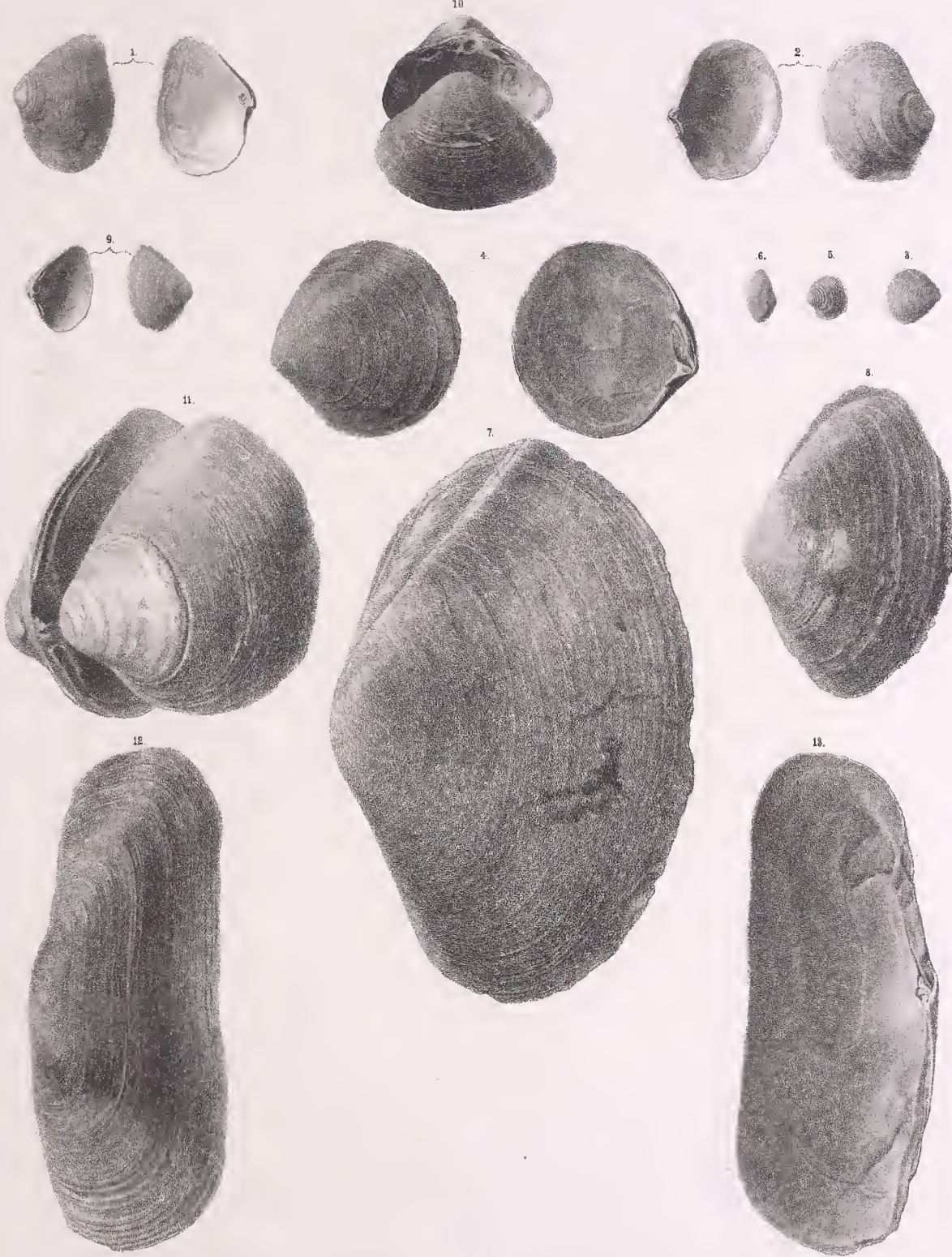

C. G. Platen del, et lith Charieston S.C.
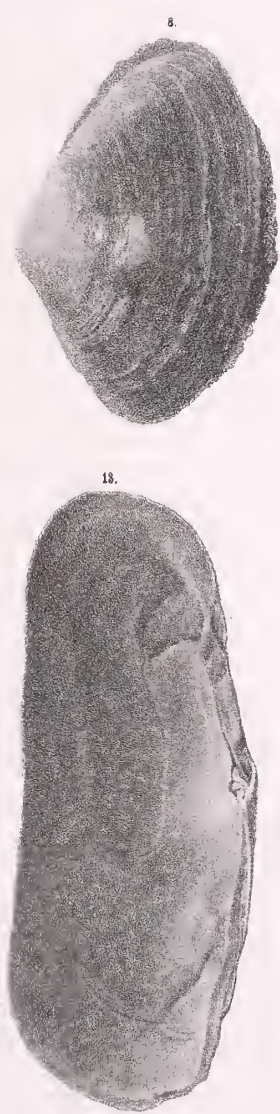




\section{PLEIOCENE FOSSILS.}

PLATE XXIV.

A N A TINID无.—SOLENID无.-PHOLADID无.

A N A TINID正.

Fig. 1. PANOP(EA REFLEXA. Natural size. Page 100.

“ 2. PHOLADOMYA ABRUPTA. Natural size, Page 101.

S OLEN I D A.

FIG. 3. SOLEN ENSIS. Natural size. Page 101.

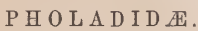

Fig, 4. PHOLAS COSTATA. Young shell, natural size. Page 102.

“ 5. PHOLAS OBLONGATA. Natural size. Page 103.

“6. PHOLAS MEMMINGERI. Left valve, natural size. Page 104. 
Pl. 24
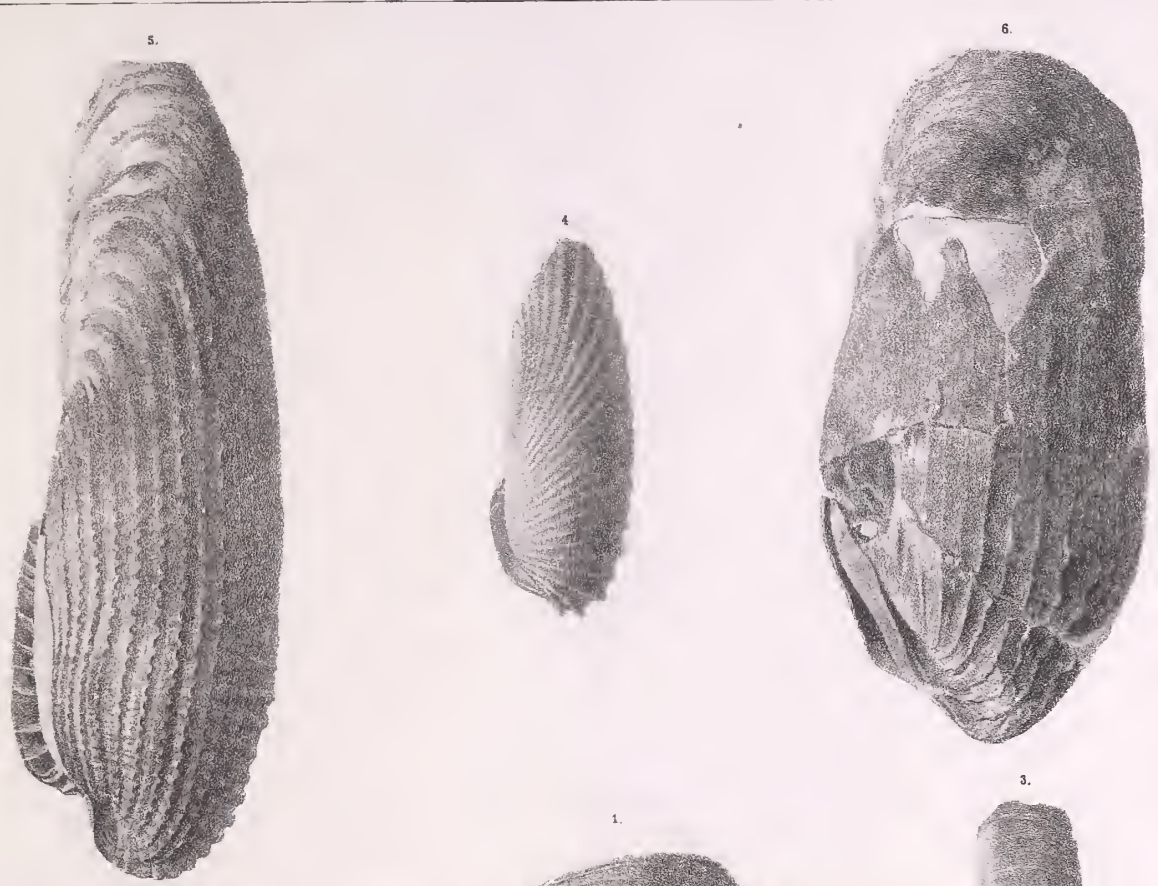

3
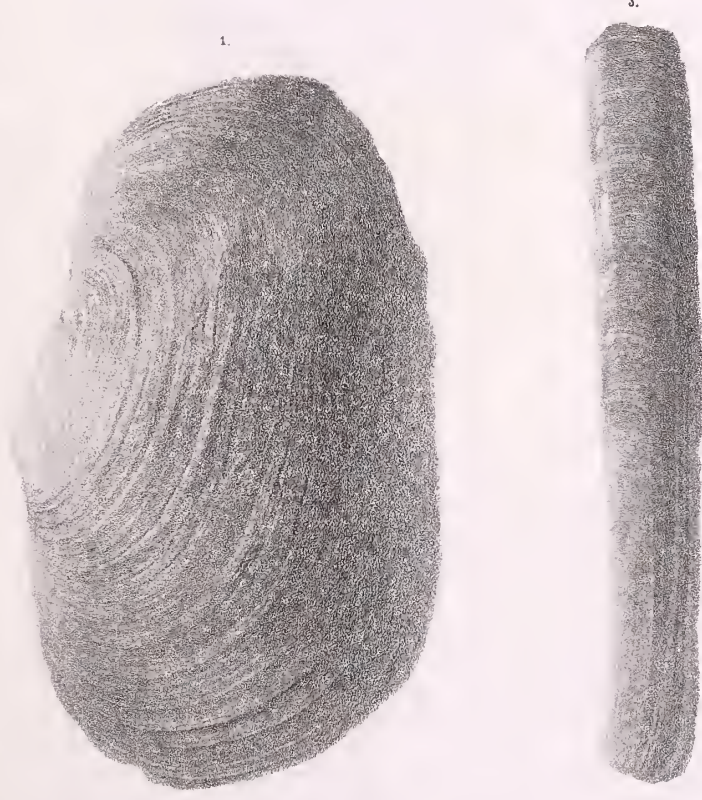

C.G. Platen ud nat del at lith Charleston S.C. 




\section{PLEIOCENE FOSSILS.}

PLATE XXV.

DENTALIADE,-CALYPTREIDE,-FISSURELLIDE-NATICIDE. D E N T A L I A D

Fig. 1. Dentalium ATtendatum. Natural size. Page 105.

“ 2. DENTAliUm Pleiocenum. Natural size. Page 105.

“ 3. Dentalium THALLUS. Natural size. Page 106.

C A L Y P T R A I D E.

Fig. 4. CRUCIBUlUm COSTATA. Interior and exterior, natural size. Page 107.

“ 5. CRUCibUlum RAMOSA. Interior and exterior, natural size. Page 108.

“ 6. CRUCIBULUM DUMOSA. Interior and exterior, natural size. Page 109.

“ 7. CRUCibUlum MULtilineata. Interior and exterior, natural size. Page 107.

“ 8. TROCHITA CENTRALIS. Interior and exterior, natural size. Page 109.

“ 9. CRYPTA FORniCata. Exterior of shell, natural size. Page 110.

“ 10. CRYPTA SPINOSA. Exterior of shell, natural size. Page 111.

“ 11. CRYPTA COSTATA. Exterior of shell, natural size. Page 112.

“ 12. CRYPTA PLANA. Exterior of shell, natural size. Page 111.

" 13. HIPPONIX BULLII. Side view to show carina. Page 112.

"13a. Outline of the aperture of H. Bullii.

\section{FIS S U R E L I DA.}

Fig. 14. FISSURELLA REDIMICULA. Natural size. Page 113.

N A T I C I DA.

Fig. 15. NATICA HEROS. Front and back view, natural size. Page 114.

“ 16. NATICA DUPLiCATA. Front and back view, natural size. Page 114.

“ 17. NATICA CANRENA. Front view, natural size. Page 115.

" 17 a. Back view of same, natural size.

" 18. NATICA CAKOLINIANA. Front and back view, natural size. Page 116. 
P1. 25

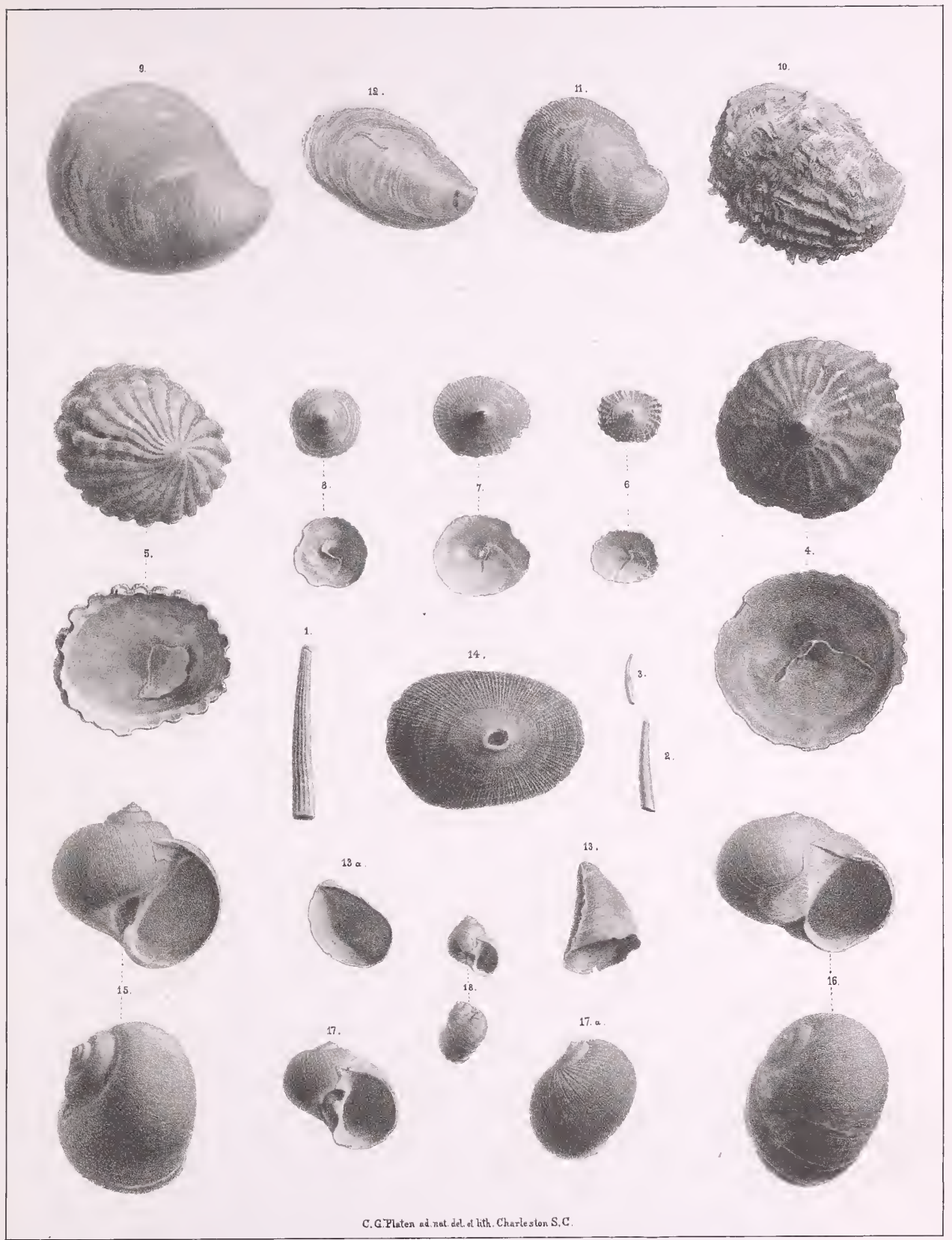






\section{PLEIOCENE FOSSILS.}

PLAIE XXVI.

\section{TURBINID E-LITTORINID E.-TURRITELLID A.--BUCCINID A.--PYRAMIDELLID A. T U R B I N I D $A$.}

Fig. 1. MONODONTA KIATHAHENsis. Natural size. Page 116.

“ 2. 'TROCHUS PHILANTROPUS. Natural size. Page 117.

“ 3. TROCHU's ARMILLtTUS. Natural siza. Page 118.

“4. TROCHUS GEMMA. Natural size. Page 118.

L I T O R I N I D A.

Frg. 5. LITTORiNa IRrorata. Natural size. Page 119.

“ 6. ARChitectonica Perspectiva. Natural size. Page 120.

T U R R I T E L L I D AE.

Fig. 7. Terebellum Striatum. Natural size. Page 120.

“ 8. TERebellum Exaltatum. Natural size. Page 121.

“ 9. TEREBELLUN EIIWANENSIS. Natural size. Page 122.

“ 10. Young shell.

“ 11. TEReBellum BURdenil. Natural size. Page 122.

“ 12. VermetUS ANGUINA. Natural size. Page 123.

“ 13. PETaloconchus SCUlPturatus. Natural size. Page 123.

“ 14. SCalaria multistriata. Natural kize. Page 124.

“ 15. SCALARIA CLathrus. Natural size. Page 124.

13 U C C I N I DA.

Fig. 16. ACUS Dislocatum. Natural siz. Page 125.

P Y R A M I E L L I DE.

Fig. 17. OBELiscus ARenOSA, Natural size. Page 126. 

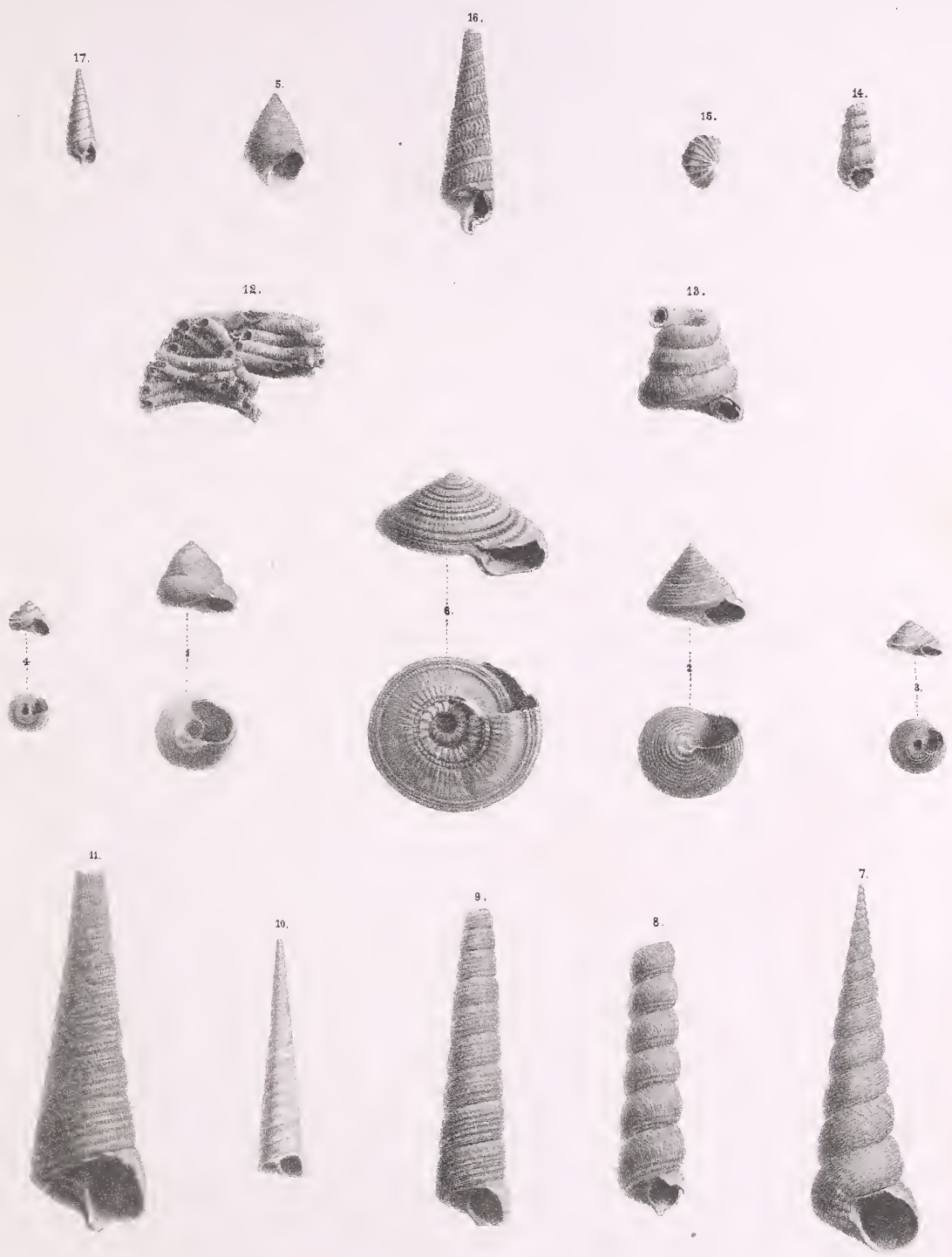




\title{
PLEIOCENE FOSSILS.
}

\author{
PLATE XXVII.
}

CYPRAIDE. -VOLUTIDE.-CONIDE.

C Y P R A D A

Fig. 1. CYPR AA CAROLINENSIS. Side view, natural size. Page 126.

"2. The same, showing aperture and base.

“ 3. CYPR AEA PEDICULUS. Side view, natural size. Page 127.

“ 4. The same, to show aperture and base.

\section{O L U T I D $A$.}

Fig. 5. VOLUTA MUtabilis. Natural size. Page 128.

“6. A variety of the same.

“ 7. VOLUTA TREnholmiI. Young shell, natural size. Page 128.

" 8. The same, adult; natural size.

“ 9. MITRA CAROLINENSIS. Natural size. Page 129.

" 10. PORCellana Limatula. Back view, natural size. Page 130.

"11. The same, front riew, to show aperture.

“ 12. PORCELLANA OLIVIfORMiS. Natural size. Page 131.

" 13 . The same, to show aperture.

$$
\text { C O N I D }
$$

Fig. 14. CONUS ADVERSARIUS. Natural size. Page 131.

“ 15. CONUS DILUVIANUS. Natural size. Page 132.

“ 16. TURris LUNATUM. Natural size. Page 132. 


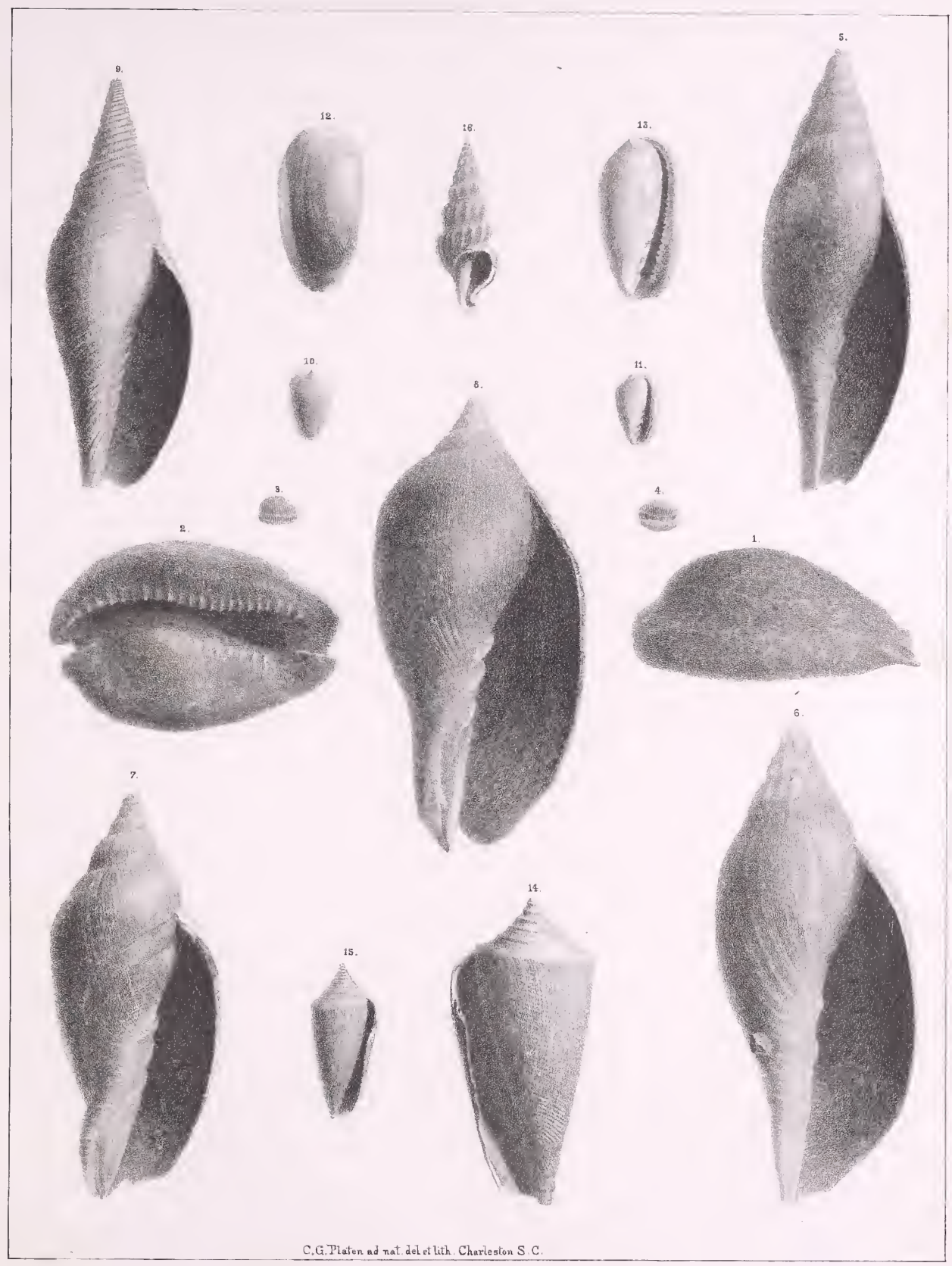





\title{
PLEIOCENE FOSSILS.
}

\author{
PLATE XXVIII. \\ B U C C I I I DE. - II U R I C I DE. \\ B U C C I N I D
}

Fig. 1. BUCCINUM PORCINUM. Natural size. Page 133.

" 2. Buccinun multirugatui. Natural size. Page 133.

"3. BUCCINUM VIBEX. Natural size. Page 134.

“ 4. BUocinum TRIVItTatun. Natural size. Page 135.

“ 5. BUCCINUAi OBSOleTUM. Natural size. Page 135.

“6. BUCCINUM LUNAtul. Natural size. Page 136.

“7. ACUS UNILINEATA. Natural size. Page 137.

“ 8. AOUS Dislodatum. Var. A. Carolinensis. See plate xxvi, fig. 16. Natural size. Page 125.

“ 9. PURPURA TRIDENTATA. Natural size, but broken. Page 137.

" 10. GALEODIA HODGII. Natural size. Page 138.

" 11. DOLIUn GALEA. A natural cast. Page 139.

“ 12. COLUMbella AVARA. Natural size. Page 139.

“ 13. STREPHONA LiteratA. Natural size. Page 140.

M U R I C I DA.

Fig. 14. CEROSTOMA UMBRIFER. Broken specimen, Page 141.

" 15. APOLlON CAUdATA. Natural size. Page 142.

" 16. CANCELlaria RETICULata. Natural size. Page 142.

“ 17. CANCELlaria DEPRESSA. Natural size. Page 143.

"18. CANCELlaria VENUSTA. Natural size. Page 144.

For other species of this family, see plates $\mathrm{xxix}$ and $\mathrm{xxx}$. 
6
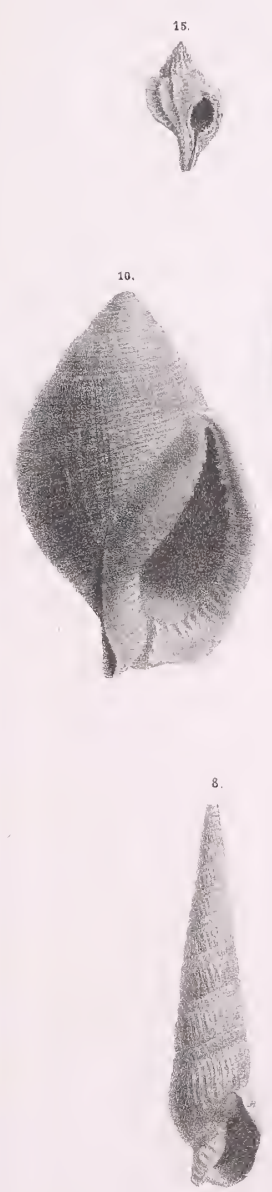

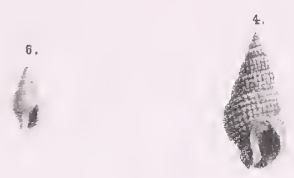

$\frac{12 .}{1}$
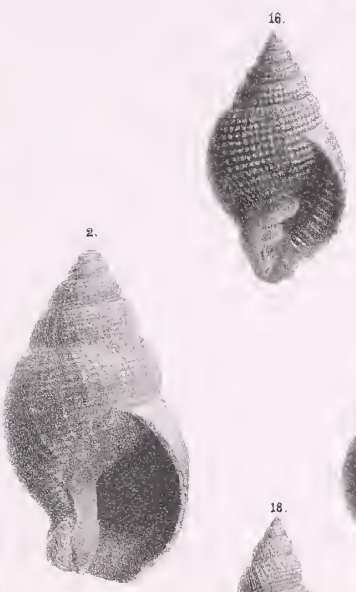

14.
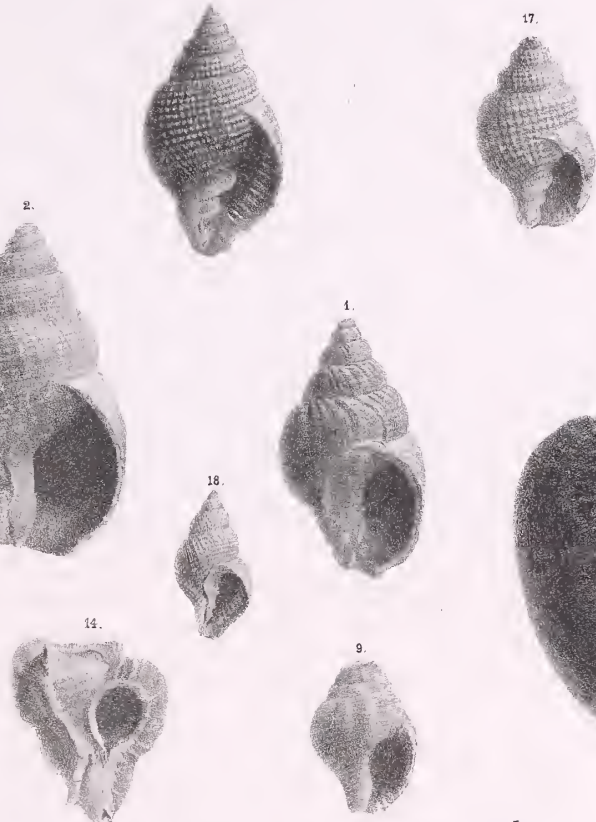
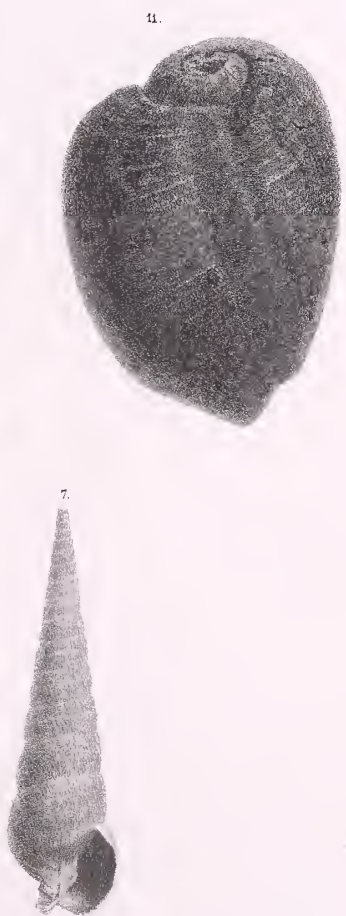



\title{
PLEIOCENE FOSSILS.
}

\author{
PLATE XXIX.
}

II U R I C I D E.

Fig. 1. BUSYCON CARICA. Natural size. Page 145.

"2. BUSYCON CANALICULATUM. Natural size. Page 146. = canaliferum Cons, fece enuw

“ 3. BUSYCON PERVERSUM. Natural size. Page 145. = adcraarmm fide Conn. -

"4. BUSYCON CONRADII. Natural size. Page 147. = excavalus vac. Dau = incile cm For others of this family, see plates xxriii and $x x x$. 


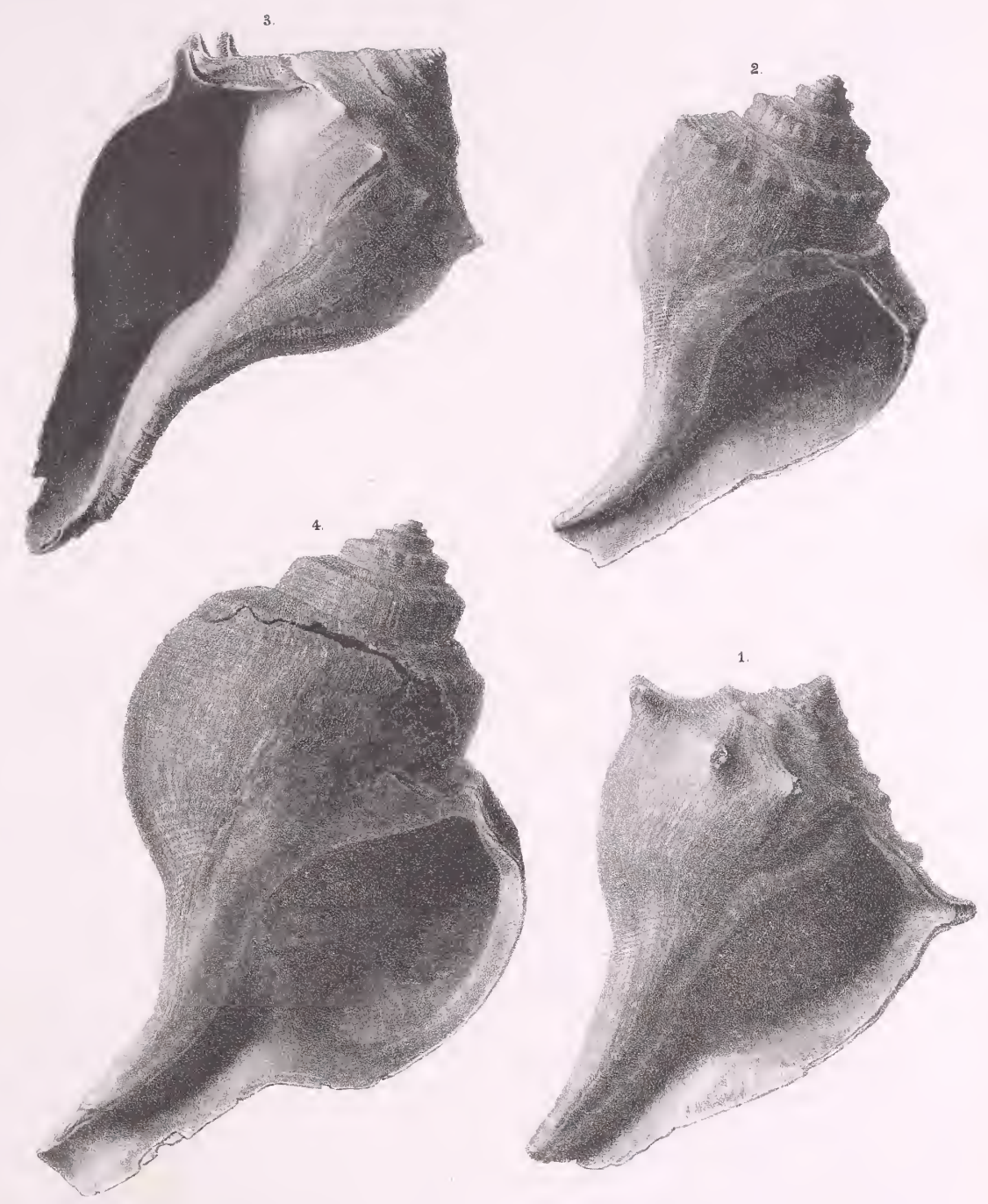

C. G Platen del. etith Charieston S. C. 




\title{
PLEIOCENE FOSSILS.
}

\author{
PLATE XXX.
}

U U R I C I D E.

Fig. 1. OASSIDUluS CAROLINENSIS. Nalural size. Page 147. = syeotyput exenvatis Comad

"2. CASSIDULUS PYRUM. Natural size. Page 148.

pyonm Sillwin

“ 3 SYCOTYPUS RETICULATA. Natmral size. Page 149.

“4. COLUS QUADRICOSTATUS. Natural size. Page 149.

"5. COLUS EXilis. Natural size Page 150.

“ 6. Colus Cinereus. Natural nize. Page 150.

“7. FAsciolaria DISTANS. Natural size. Page 151.

“ 8. Variety of the same, natural size.

“ 9. FASCIOLARIA GIGANTEA. Natural size. Page 152.

“ 10. FASClolaria TUOMEYI. Natural size. Page 152. 
PI 30.
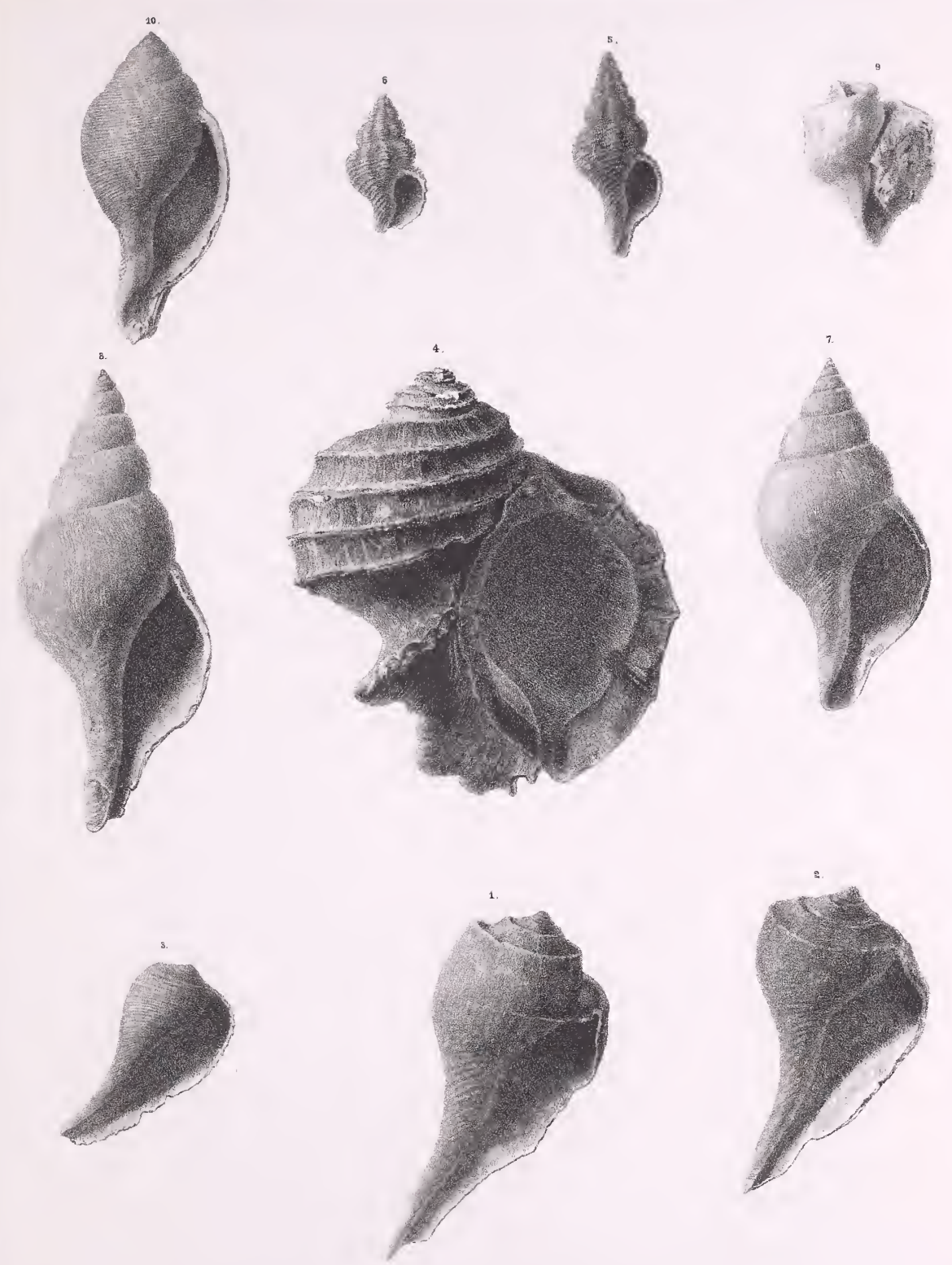



\section{FOSSILS OF SOUTH-CAROLINA.}

BY

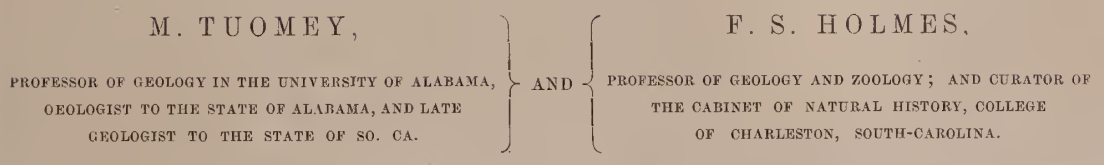

I $0 \cdot 1 \cdot($ Pe. 1-द)

CHA RLESTON, S. C .

JOHN RUSSELL, 251 KING-STREET.

1855. 
Professor L. Agassiz, Professor L. R. Gibbes, Professor Joseph Leidy and John McCradt, Esq., have kindly tendered their services in describing some of the new species of Fossil Fish, Crustacea, Mammalia and Echinodermata, for publication in this work; the initials of those authors will be found under their respective articles. 


\section{FOSSILS OF SOUTH-CAROLINA.}

$\mathrm{BY}$

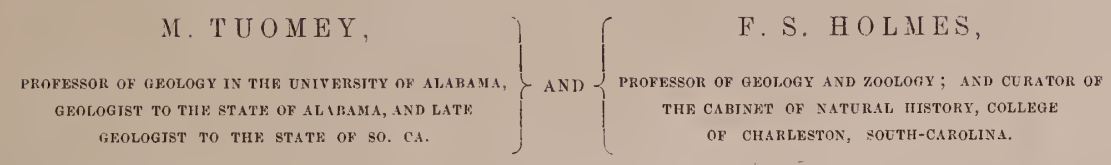

No.2. $2.9+17)$

CHA RLESTON, S. C.

J OHN RUSSELL, 251 KING-STREET.

1855. 



\section{FOSSILS OF SOUTH-CAROLINA.}

BY

M. TUOMEY, ROELSSOR OF GEOLOGY IN TUE CNITERSTTY OF ALABAMA, GLOLOGIST TO THE STATE OF ALABAMA, AND LATE GEOLOGIST TO THE STATE OH SO. CA.
F. S. HOLMES,

$\left\{\right.$ AND $\left\{\begin{array}{c}\text { H. S. H O L M E S } \\ \text { PROFESSOR OF GHOLOGY AND zOOLOGY ; AND CURATOR OF } \\ \text { THE CABINEY OF NATURAL HISTORY, COLLEGE } \\ \text { OF CHARLESTON, SOUTH-CAROLINA. }\end{array}\right.$

Nos. 3 ANd 4 . ef, 17 to 36

CHARLESTON, S. C.

J0HN RUSSELL, 251 KING-STREET.

1855. 



\section{FOSSILS OF SOUTH-CAROLINA.}

M. TUOMEY, $\quad$ T. S. HOLMES,

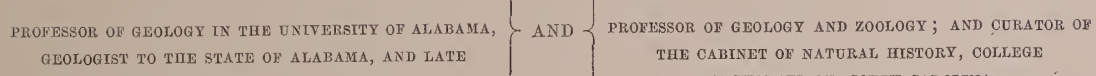

GEOLOGIST TO THE STATE OF SO. CA. OF CHARLESTON, SOUTH-CAROLINA.

NOS. 5 AND $6 .(p e .27-30)$

CHARLESTON, S. C.

JOHN RUSSELL, 251 KING-STREET.

1855. 



\section{FOSSILS OH SOUTII-CAROLINA.}

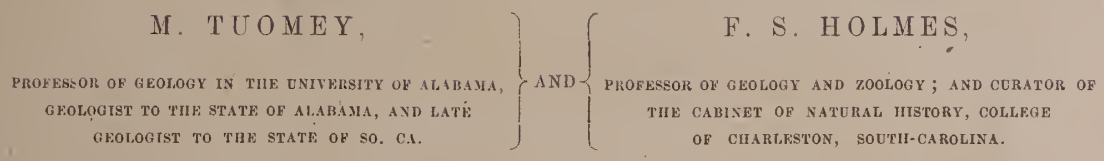

No. i.

pp $31-3$

C II $\Lambda$ R I E S T ON, S. C.

RUSSELL \& JUNEG, 251 KING-STREET.

1856 . 



\title{
FOSSILS OF SOUTH-CAROLINA.
}

\section{BY}

\author{
M. TUOMEY, $\quad$ T F. S. HOLMES, \\ PROFESSOR OF GEOLOGY IN THE UNIVERSTTY OF ALABAMA, $\}$ AND $\{$ PROFESSOR OF GEOLOGY AND ZOOLOGY; AND CURATOR OF \\ gEOLOGIST TO THE STATE OF ALABAMA, AND LATE \\ GEOLOGIST tO THE STATE OF SO. CA. \\ THE CABINET OF NATURAL HISTORY, COLLEGE \\ OF CHARLESTON, SOUTH-CAROLINA.
}

\section{$\mathrm{N}(\mathbf{0} \cdot 8 \cdot(0-2: 9-46$ :}

C H A R L E S T ON, S. C. RUSSELL \& JONES, 251 KING-STREET. 



\section{FOSSILS OF SOUTH-CAROLINA.}

M. TUOMEY, $]$ F. S. HOL M E S,

PROFESSOR OF GEOLOGY IN THE UNIVERSITY OF ALABAMA, $\}$ AND $\{$ PROFESSOR OF GEOLOGY AND ZOOLOGY; AND CURATOR OF GEOLOGIST TO THE STATE OF ALABASIA, AND LATE GEOLOGIST TO THE STATE OF SU. CA. the gabinet of Natural history, gollege
of charieston, soeti-carolina.

\section{Nos. 9 AND 10.}

\section{CHARLESTON, S. C.}

R USSELL \& JONES, 251 KING-STREET.

1856.

JAMES \& WILLIAMS, PRINTERS, 16 STATE STREET 



\section{FOSSILS OF SOUTH-CAROLINA.}

BY

\begin{tabular}{|c|c|c|}
\hline M. T U O M E, & & F. S. HOLM E S, \\
\hline $\begin{array}{l}\text { OFESSOR OF GEOLOGY IN THE UNIVERSITY OF ALABAMA, } \\
\text { GEOLOGIST TO THE STATE OF ALABAMA, AND LATE } \\
\text { GEOLOGIST TO THE STATE OF SO. CA. }\end{array}$ & AND & $\begin{array}{c}\text { PROFESSOR OF GEOLOGY AND ZOOLOGY; AND OURATOR OF } \\
\text { THE CABINET OF NATURAL HISTORY, COLLEGE } \\
\text { OF CHARLESTON, SOUTH-CAROLINA. }\end{array}$ \\
\hline
\end{tabular}

NoS. 11 AND 12.

CHARLESTON, S. C.

RUSSELL \& J0NES, 251 KING-STREET.

1856 .

JAMES \& WILLIAMS, PRINTERS, 16 STATE-STREET 



\section{FOSSILS OF SOUTH-CAROLINA.}

\section{T U O M E Y,}

PROFESSOR OF GEOLOGY IN THE UNIVERSTTY OF ALABAMA, GEII.OGIST TO THE STATE OF ALABAMA, AND LATE GEOLOGIST TO THE STATE OF SO, CA.
F. S. HOL M E S,

PROFESSOR OF GEOLOGY AND ZOOLOGY; AND CURATOR OF THE CABINET OF NATURAL HISTORY, COLLEG OF CHARIESTON, SOUTH-CAROLINA.

NOS. 13 AND 14. ee. 105-144?

CHARLESTON, S. C.

R USSELL \& JONES, 251 KING-STREET. 1856.

JAMES \& WILLIAMS, PRINTERS, 16 STATE-STREET. 



\title{
FOSSILS OF SOUTH-CAROLINA.
}

BY

M. T U O M E Y, PROFESSOR OF GEOLOGY IN THE UNIVERBITY OF ALABAMA, CROLOGIST TO THE STATE OF ALABAMA, AND LATE GEOLOGIST TO THE STATE OF SO. CA.
F. S. HOL M E S, PROFESSOR OF GEOLOGY AND ZOOLOGY; AND CURATOR ON THE CABINET OF NATURAL HISTORY, COLLEGE OF CHARIESTON, SOUTH-CAROLINA.

\section{No. $15.0145-152$}

\author{
CHARLESTON, S. C.
}

R USSELL \& JON E S, 251 KING-ST P E ET. 1856. 



\section{POST-PLEIOCENE FOSSILS}

OF

\section{SOUTH-CAROLINA.}

BY

\section{FRANCIS S. HOLMES, A.M.,}

PROFESSOR OF GEOLOGY AND PALEONTOLOGY, AND CERATOR OF THE MUSEUM OF NATURAL HISTORY, COLLEGE OF CHARLESTON, SO. CA.

MENBER OF THE AMERICAN ASSOCIATION FOR THE ADVANCEMENT OF SCIENCE; CORRESPONDENT OF THE ACADEMY OF NATURAL SCIENCES OF PHUADELPHIA, AND LYCEUM OF NATURAL HISTORY, NEW-YORK.

CHARLESTON, S. C.

RUSSELL \& JONES, 251 KING-STREET. 1860 . 



\section{GEORGE A. TRENHOLM, ESQ,}

As an evidence of my friendship and regard,

\section{A N D}

in grateful acknowledgment under which his kindness has placed me,

THIS VOLUME

descriptive of the fossils of the Post-Pleiocene of our Native State, and belonging to

a period in the geological sequence, connecting the past with the present History of our Earth,

IS DEDICATED,

by his friend and kinsman,

FRANCIS S. HOLMES. 


\section{PREFACE.}

Extracts from the papers included in this volume were published in pamphlet form, March 1st, 1858; but the edition was soon exhausted. The discovery of fossil bones and teeth which could not be distinguished from similar parts of recent domestic animals, excited general attention, and the subject was freely discussed in the public press both at home and abroad.

In April, 1859, additional evidence of the age of the beds from which these fossils were obtained, was afforded by the discovery of a fragment of Indian pottery associated with the bones and teeth of mastodon, horse, deer, etc., (Plate XIX and XX.) These specimens were takien to Philadelphia, and submitted to the inspection of the members of the Academy of Natural Sciences, at a meeting held July 12th, and published in their proceedings of that evening, page 177. The subject caused considerable speculation, and it was concluded to republısh in part what had already appeared in the pamphlet issued in 1858 .

A description of the geological formations or beds in which these remains have been obtained, etc., etc., will be found in the introduction to this volume.

\section{ACKNOWLEDGNENTS.}

In acknowledging our obligations to friends who have kindly assisted us whilst engaged In the preparation of this work, the first place is due to Prof. Joseph Leidy, the eminent anutomist of the University of Pennsylvania, for devoting so much of his valuable time and talents to our aid in describing the vertebrata; lis kind attention to our interest places us under profound obligations to him.

To Major A. H. Bowman, U. S. A., Chief of the Architectural Bureau at Washington, we are under particular obligations for the use of his valuable and rare collection of fossils from the Ashley beds, and for the deep interest he has always evinced in our work.

Our sincere thanks are also gratefully tendered to the following gentlemen, from whom we have received many kind favors: Dr. Edmund Ravenel, of the Grove, St. Thomas; Henry W. Ravenel, Esq., of Aiken, S. C.; Wm. Simmons, Esq., Yonge's Island, S. C.; Dr. Klipstein, Clrist Church; Maj Wm. M. Murray, Edisto Island; Jabez J. R. Wescoat, Esq., Edisto Island; Chas. Boutelle, Esq., U. S. Coast Survey; Prof. Wm. Hume, Citadel Academy; Prof. Sainl. H. Dickson, Jefferson College, Philadelphia; Alderman Lucas, Charleston; Dr. R. W. Gibbes, Sen., Columbia, S. C. 


\section{POST'PLEIOCENE FOSSILS.}

\section{IN TRODUCTION.}

The Post-Pleiocene period is marked in the geological sequence, as that interesting epoch when life upon our globe was manifested in those organic forms, chiefly of the same species that belong to the historical, or present period, and were obviously designed "from the beginning" to be the contemporaries and companions of man, who appeared immediately afterwards ; "The crowning point of creation."

It is the last formation of the Cainozoic or Terliary, the epoch just antecedent to the advent of man upon this earth; a period in which, it may be said, the earth had been finally prepared and made ready for him who was to be formed in the likeness of the Creator, and was to have dominion given himı over "the fish of the sea, the fowls of the air, the beasts of the earth, the herb and every creeping thing, yea-over all the earth ;" a perjod that will ever be distinguished as the grand connecting link between the past and the present.

Sir Chas. Lyell, who is considered the best authority on tertiary geology, placed this connection in a striking point of view, having ascertained that ninety-five per cent of the fossils of the Post-Pleoicene period, are identical with living species.

The crust of the earth, as far as the researches of geologists extend, appears to be separated into strongly marked divisions, that seem to have been formed during four distinct and prolonged periods. These periods, for the sake of convenience, have been named in accordance with the class of animals and vegetables in existence during the formation of each, evidences of which we find preserved in their fossil remains.

The first division has been called Azoic; which signifies without life; the rocks of this age consist of granite gneiss, etc.; they contain no traces of organic forms, and being the lowest or first formed in the series, and originally in an incandescent state, passed, no doubt, into the condition of rocks, before the creation of animals and plants.

In the second division, the Palaozoic, or ancient life, we have indications of the first animals and plants created, not one species of which has outlived the convulsions that 
separated this period fromits successor; and that served, apparently, in each case to mark the close of one period and the commencement of another.

The next in order and third of the series, is named the Mesozoic or middle life, and its fossils belong to that middle or intermediate class of animals between the most ancient and recent forms. These also in turn became, like their predecessors extinct, and were succeeded by a later creation.

The next and last age is named the Cainozoic —recent life-and by some authors called the Tertiary, or third grand division, and in which we discover, for the first time, the created forms that are to be the cotemporaries of man.

These divisions, or grand divisions, as they may be called, are again sub-divided into minor periods or formations; the first, consequentely the lowest and oldest in the series of the Cainozoic or Tertiary, is called Eocene, for in it we find representatives of the dawn or commencement of that creation; a few species, two or three per cent, only, having been perpetuated down to the present time.

In the Merocene, the next in age, a larger number of species are found whose existence is thus prolonged.

In the Plejocene, more recent, a majority of the fossils are of recent species; and at last, in the Post-Pleiocene-the most recint-ninety-five per cent, or nearly all the species, continue to the present time. This last, the Post-Pleiocene, is an extensive formation in the low or flat country of South Carolina and is included in a belt extending from the sea coast about ten miles inland, and occupies depressions in the great marl bed of the Eocene period.

Three distinct formations or beds are here supposed to belong to this age. First the marine beds, composed of a gray sandy clay in which are imbedded innumerable small shells, sometimes very comminuted, but of species now common and living on the coast; many of the large shells are preserved in the position they occupied when living, having both valves entire and perfect, and presenting the appearance of having been destroyed suddenly by an avalanche of sand.

The second, is the blue or pluff-mud bed, composed of a stiff blue clay, containing silicious pebbles, and masses of conglomerates, water-worn and boulder-like, but no angular blocks, and includes remains of marine and terrestrial animals. These pebbles and rolled conglomerates contain casts of the fossils common to the marl of the Eocene bed upon which the blue mud rests, and it has been ascertained that the silicious conglomerates are fragments of the marl, broken off, we infer, by the action of waves, and rolled upon the beach of a Post-Pleiocene sea; they afterwards were imbedded in the blue mud, lost all their lime or calcareous particles, and became silicified.

The third or upper bed includes the peaty deposits, yellow sands and clays, which overlie the pluff-mud.

Sections of the three most important localities may be represented in the following tables: 


\section{MARINE BEDS OF THE WADMALAW.}

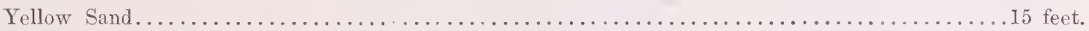

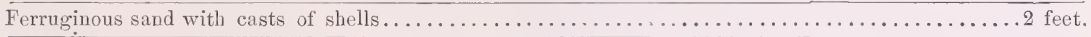

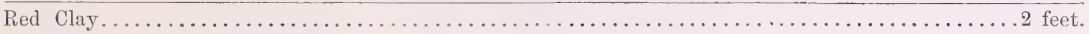
Gray sand and mud with comminuted shells, fossils in fine preservation $\ldots \ldots \ldots \ldots \ldots \ldots \ldots \ldots \ldots \frac{3}{2}$ feet.

ASHLEY RIVER BEDS.

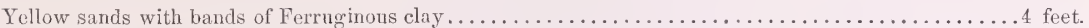
Blue mud resting on the white Eocene marl. . . . . . . . . . . .

GOOSE CREEK BEDS.

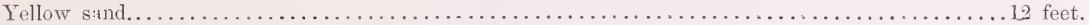

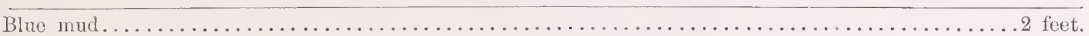

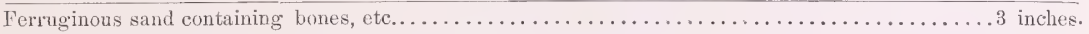

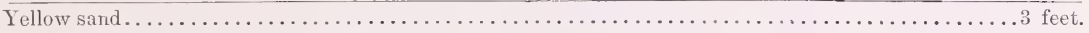

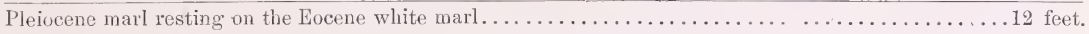

The fossil bones obtained from some of these strata are often in a fine state of perservation, especially those taken from the blue mud, which are generally petrified; those from the sands are likewise well preserved, but in the peaty or upper beds they are not so petrified, retain all their gelatine and appear to decompose rapidly.

Dr. Klipstein, who resides near Charleston, in digging a ditch for the purpose of reclaiming a swamp, discovered and sent me the tooth of a mastodon, with the request that $\mathrm{I}$ should go down and visit the place, as there were indications of the bones and teeth of the animal still remaining in the sands which underlie the peat-bed. Accordingly, with a small party of gentlemen, we visited the Doctor, and succeeded not only in obtaining several other teeth and bones of this animal, but nearly one entire tusk, and immediately along side of the tusk discovered a fragment of pottery which is similar to that manufactured at the present time by the American Indians. The depth of the excavation was about three feet below the surface; bones of the deer and two teeth of a horse were also found.

This is not a drift-bed, but a deposit of the peat and sand of the Post-Pleiocene formation. The marine beds with their characteristic shells lie immediately beneath, and are exposed on the high land which surrounds the swamp. If we take the one hundred and fifty species of mollusca, whose shells are so beautifully preserved in these beds, and place the entire group along side a similar collection of shells of the recent species living upon the coast, we will observe that they are identically the same in form, character and every other respect. There are among the fossils two shells whose analogues are not now living upon the sea coast of Carolina, but are common in the gulf of Mexico, and West Indian seas. Strombus pugilis, abundant on the coast of Florida and Cuba, is a fossil of the Post-Pleiocene; and Gnathodon cuneatum, now living in the estuaries near Mobile, and along the 
northern coast of the Gulf is found fossil at a depth of eighteen or twenty feet under the city of Charleston, and in such numbers that cart-loads may be obtained from a single locality.

Again, we find two more species that are now extinct, or rather unknown to me in a recent state, one of which I have lately figured and described as Cavolina Tuomeyi, after my late friend and colleague Prof. Tuomey; the other is Telledora lunulata, Adams, a shell described as recent, from Carolina, but in fact a fossil in the Post-Pleiocene and extinct.

Now let us compare the remains of the vertebrata with a similar group of living animals. Among the former we find teeth of the deer, raccoon, opossum and others well known to be living at the present time in South Carolina; but like the invertebrated we find two or three species which are no longer existing north of Mexico and South America-the pecca$r y$, the capybara and the tapir. Again, there are remains of the musk-rat and beaver, but these two animals are extinet in the low country of South Carolina; the beaver has indeed almost been extirpated to the east of the Mississippi river, and the musk-rat is confined to a region above the falls of the rivers of this State.

The mastodon, the megatherium, the mylodon and perhaps one or two others are extinct.

That we may the better appreciate the interesting analogy existing between these two groups as regards the living and extinet species, we will place them in a tabular form, thus :

\begin{tabular}{|c|c|c|}
\hline Fossil Remains. & Mollusca. & Vertebrata. \\
\hline 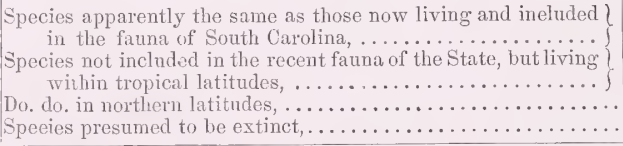 & $\begin{array}{l}\ldots \ldots \text { say } 140 \ldots \ldots \\
\ldots \ldots \ldots \text { say } 2 * \ldots \ldots \ldots \\
\ldots \ldots \ldots \\
\ldots \ldots \ldots \text { say } 2+\ldots \ldots \ldots\end{array}$ & 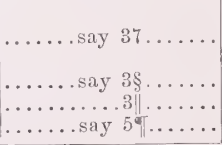 \\
\hline
\end{tabular}

Among the fossils collected in South Carolina from beds of this age-Post-Pletocene — some of which are exposed at Ashley Ferry, Goose Creek, Stono, John's Island, and other localities, a number have been found apparently belonging to animals having specific characters in common with recent or living species not considered indigenous to this country, such as the horse, hog, sheep, ox, etc.

A large collection of fossils from this interesting formation were submitted by me about three years ago, to Professor Leidy, of Philadelphia, the eminent palæontologist, for deter-

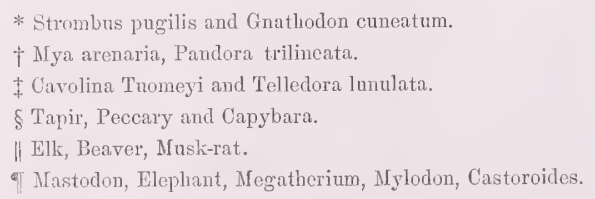


mination; of these a number were returned with the remark, that they appeared to belong to recent species which had become accidental occupants of the same bed with the true fossils. I held the opposite opinion, and believed that these relics were indeed true fossil remains, as they were obtained not only from the banks and àeltas of rivers, but a large number from excavations several feet below the surface, and at a distance from any stream, creek, pond, bog or ravine; and in some cases, from excavations below the high sandy land of cotton fields.

In a letter to Dr. Nott and Mr. Gliddon, dated Feb. 10, 1857, Prof. Leidy writes:

"Some time since, Professor F. S. Holmes, of Charleston, submitted for my examination, a collection of fossil bones from a Post-Pleiocene deposit on Ashley River, S. C. Among remains of the extinct horse, the peccary, mylodon, megatherium, mastodon, hipparion, the tapir, the capabara, the beaver, the musk-rat, etc., were some which I considered as belonging to the dog, the domestic ox, the sheep and the hog. Prof. Holmes observes that these remains were taken from an extensive deposit, in which similar ones exist abundantly, and he further adds, that he cannot conceive that the latter should have become mingled with the former, since the introduction of domestic animals into America by Europeans. It is not improbable that the American continent once had, as part of its fauna, representatives of our domestic animals, which subsequently became extinctthough I am inclined to doubt it; but what we have learned of the extinct American horse will lead me carefully to investigate the subject."

The opportunity for prosecuting this investigation, to some extent, I had the pleasure of affording Professor Leidy, in March last, a month after the date of the above letter. Dr. Hallowell and himself visited me in Charleston, and I accompanied them to Ashley Ferry and Goose Creek.

In a paper written after the Professor's return to Philadelphia he says: "The collections of these gentlemen consist of a most remarkable intermixture of remains of fishes, reptiles and mammals, of the three periods mentioned; and in many cases perhaps we may err in referring a particular species to a certain formation, more especially in the case of the fishes. The remains usually consist of teeth often well preserved, but frequently in small fragments, more or less water-worn, and most of the fossils are stained brown or black."

The fossils from Ashley Ferry present, as a group, the same appearance as those procured inland at some distance from the river, by digging from three to five feet below the surface. Many specimens from the ferry were considered as recent by Professor Leidy; they appear quite fresh and unchanged in color, and their texture not in the slightest degree altered. To one familar with the fossils of the South Carolina Post-Pleiocene, this excites no surprise, as it is of common occurrence, more especially among the shells; for example, the olive shell-Oliva literata -is found as fresh and highly polished as the recent ones from the sea-beaches along the coast; and Cardium magnum retains often, the delicate yellow and brown markings; common to the species. 
The color or texture of a fossil, therefore, does not always absolutely determine its relative age; as Professor Leidy has himself remarked in a foot-note to his letter alluded to above, viz ;

"Fossilization, petrification, or lapidification, is no positive indication of the relative age of organic remains.

"The Cabinet of the Academy of Natural Sciences, of Philadelphia, contains bones of the megalonyx, and of the extinct peccary, that are entirely unchanged; not a particle of gelatin has been lost, nor a particle of mineral matter adder, and, indeed, some of the bones of the former even have portions of articular cartilage and tendinous attachments, well preserved."

Fig. 8, Plate XXIV, is the tooth of a sperm whale found in the Aslley beds. This specimen, when submitted some years ago to Prof. Leidy, was instantly recognized as a true fossil, similar in color and general character to those of the Ashley beds; specimens from these beds being more fossilized or petrified than those found in the peat-bogs and shell-beds of other localities. Fig. 9, of the same Plate, represents another tooth of the same species, from the Charleston shell-beds, and is as recent and fresh in appearance, as though just taken from the living whale.

From the foregoing it would appear that of the ancient fauna of America, which included representatives of many of our present domestic animals, some species have undoubtedly become extinct; but I confess I am not yet prepared to admit from any evidence yet adduced, or from my own examinations, that all of the living species are distinct from those found fossil in the Post-Pleiocene. The teeth and bones of the rabbit, raccoon, opossum, deer, elk, hog, dog, sheep, ox and horse are often found in these beds, and though associated with those known to be extinct, such as mastodon, megatherium, hipparion, etc., need not necessarily be referred to extinct races also, since their remains cannot be distintinguished from the bones and teeth of the living species.

Of the mollusca from the same beds about ninety-five per cent. are to my mind identically the same with species now living on the coast of South-Carolina. Two species of these shells though extinct or not in existince here, are now living in numbers on the coast of Florida and the northern shores of the Gulf of Mexico;" and two have no living representatives that we can discover. $\dagger$

The question therefore naturally suggests itself-are the living horses, dogs, hogs, raccoons, opossums, deer, elk, tapirs, beavers, etc., and the one hundred and fifty living shells of the coast, the descendants of the animals whose remains we find fossil in the abovenamed beds?

It has been just remarked that about ninety-five per cent., or nearly all of the one hundred and fifty shells of molluscous animals from these beds, are specifically identical with

* Strombus pugilis; Gnathodon cuneatum.

† Carolina. Tellina. 
the recent or living species of the coast,- -two are found only at the south of this, and two are extinct. Of the vertebrates, from the same bed, the tapir, peccary, raccoon, opossum, deer, musk-rat, rabbit, beaver, and elk have still their living representatives, generically, if not specifically; and even of the identity of species there seems to be no doubt, as no anatomical differences can be discerned. Two of these species, like the mollusca just alluded to, no longer live in South Carolina; the tapir and peccary are only found in South America and Mexico; the musk-rat, elk and beaver, though extinct on the Atlantic coast, are still living in the interior of the country. And though it has been acknowledged that the mastodon, megatherium, elephant, glyptodon, and two species of Equine genera, etc., are entirely extinct, yet the discoveries made of the remains even of some of these, would indicate that they still existed at a period so recent, that, in the language of Prof. Leidy, "it is probable the red man witnessed their declining existence."

The peccary, or Mexican hog, an animal common in Mexico, is not indigenous to the Atlantic United States; but his bones have been found associated with human remains in caves used as cemeteries by the Aboriginees." "A tomb in the city of Mexico," according to Clavigero, $\uparrow$ "was found to contain the bones of an entire mammoth, the sepulchre appearing to have been formed expressly for their reception." And "Latrobe relates that during the prosecution of some excavations, near the city of Tezcuco, one of the ancient roads or causeways was discovered, and on one side, only three feet below the surface, in what may have been the ditch of the road, there lay the entire skeleton of a mastodon. It bore every appearance of having been coeval with the period when the road was used.".

Again I extract from Prof. Leidy's letter:t

"The early existence of the genera to which our domestic animals belong, has been adduced as presumptive evidence of the advent of man at a more remote period than is usually assigned. It must be remembered, however, even at the present time, that of some of these genera only a few species are domesticated: thus of the existing six species of Equus (Horse) only two have ever been freely brought under the dominion of man.

"The Horse did not exist in America at the time of its discovery by Europeans; but its remains, consisting chiefly of molar teeth, have now been so frequently found in association with those of extinct animals, that it is generally admitted once to have been an aboriginal inhabitant. When I first saw examples of these remains I was not disposed to view them as relics of an extinct species; for although some presented characteristic differences from those of previously known species, others were undistinguishable from the corresponding parts of the domestic horse, and among them were intermediate varieties of form and size. The subsequent discovery of the remains of two species of the closely allied extinct genus Hipparion, in addition to the discovery of remains of two extinct equine genera of an earlier

\footnotetext{
* Bradford's Amcriean Antiquitios, p. 31.

+ Bradford's American Antiquities, p. 227.

* Nott and Gliddon, Indigenous races of the earth; p. xriii.
} 
geological period, leaves no roorn to doubt the former existence of the Horse on the American continent, contemporaneously with the Mastodon and Megalonyx: and man probably was his.companion."

Lieut. Michler in his report on the Pimos and Maricopas Indians, remarks:" "The former are further advanced in the art of agriculture, and are surrounded with more comforts than any uncivilized Indian tribe I have ever seen. Besides being great warriors, they are good husbandmen and farmers, and work laboriously in the field. They are the owners of fine horses and mules, fat oxen and milch cows, pigs and poultry, and are a wealthy class of Indians. The Pimos consider themselves the regular descendants of the Aztecs, and claim 'Montezuma' to have been of their tribe. One of their legends speaks of his leaving them on horseback on his pilgrimage to found a new country."

"The Indians of North America knew that the Mastodon had a trunk; a fact-though the anatomist infers it from the bones of the skull-it is difficult to imagine them to be acquainted with, except by tradition from those who had seen the living animal.

"No evidence of man's presence has occurred older than the latest Tertiary deposits, which insensibly merge into the alluvial. It seems certain that human remains have been found in chronological association with those of animals long extinct, and there appears no reasons to doubt that some species of animals, as the Irish Deer, the Moa of New Zealand, and the Dodo of the Mauritius, have disappeared from creation within a period of a few centuries." $\dagger$

EXTRACT FROM THE PROCEEDINGS OF THE DIPERIAL SOCIETY OF EMULATION SÉANCE, OF JUNE 23, 1859.\$

"For the past twelve years, the world of science has been occupied with the discovery of stones cut by the hand of man, made by our honorable President, M. Boucher de Perthes, in the diluvium, and the deposits of fossil bones, of which an account was given in $\mathbf{1 8 4 7}$, in his work, "Antiquités Celtiques et Antédilnviennes." The existence of man, contemporaneously with the deluge, so often disputed, despite the proofs given in the work just cited, has just received a signal confirmation.

Mr. Joseph Prestwick, a member of the Royal Society, and of the Geological Society, of London, has visited Abbéville and Amiens.

After having examined the collection of M. Boucher de Perthes, Mr. Prestwick, with the assistance of the Antiquarian Society of Picardy, caused large excavations to be made in the dihurial beds which surround these

\footnotetext{
* Emory's Report on the U. S. and Mexican Boundary, p. 117.

$\dagger$ Gosse. Omphalos, p. 84 .

\# Translated and published by Mr. Kinsing, Phila, 1859.

$\S$ In 2 vols, large 8vo, with 106 plates, containing 2000 figures, Paris, 1847. Copies can be seen in the Pliladelphia Library, and in the Astor Library, New Fork.
} 
two eities; and, after several days researeh on the spot, he has acknowledged the correctness of the statements of M. de Perthes, and establishes most fully his great discorery."

"These faets are set forth in a letter, (written in Freneh,) of which the following is a eopy:

Monsieur Borcher de Perthes.

London, 14th May, 1859.

President of the Imperial Soeiety of Emulation, Abbéville.

In writing to you a few days ago I omitted speaking iu regard to the opinions that I formed concerning the deposits in which the axes of Silex are found.

Aud first, as to those which you showed me, and those whieh I obtaincd at $\Lambda$ bbéville and $A$ micns, I lave not the slightest doubt but that they were cut by the hand of man. I speak at present only of those iu Silex called axes.

After having attentively examinct the beds at Mouliu-Quignon, and those of St. Gilles at Abbéville, and St. Acheul at Amiens, I am convineed that the opinion which you advanced in 1847 in your work on the "Antiquités Celtiques et $\Lambda$ ntédiluvienues," that thosc axes found in an undisturbed deposit (terrain vierge,) aud associated with the bones of the great mammifers, is eorrect and well founded.

With respect to the beds of Menchecourt, the fact does not appear so eertain to me; yet I do not see any error.

Permit me to observe, that up to the time of my visit, I had the strongest doubts iu regard to the eharaeter of these beds. I thought it possible that there might have been some unperceived geological error. I am very glad to have been enabled to eonvinee myself, through personal research of the truth of so importaut a fact.

You are at liberty sir, to make what use you may please of this letter. Accept my thanks, and the assuranee of nyy high regard.

JOSEPH PRESTWICK.

Mr. Joseph Prestwick, anthor of several well known works on Geology, after the verification made at Abbéville and Amieus, wished to assure himself whether the diluvial beds iu England were analogous. Accordingly, in the course of May, he opened at Hoxne in Suffolk, a bed of diluvinm, and after having established its perfect analogy with those at Abbéville and Amieus, he also found there similar fossil bones and flint axes. Such is the result announced in another letter of this learned Geologist."

"His reports to the Royal Society, and to the Geologieal Society, excited great interest, and several of their members accompanied Mr. Prestwick in a seeond visit which he made us. These gentlemen arrived at Amiens on the 28th May, and on the 30th at Abbéville. The examination of the beds, which lasted several days, was condueted on a much more extensive scale, and the same results were obtained, as the following letter shows:

M. Botcher de Pertues,

LoNDox, 8th June, 1859.

President of the Imperial Society of Emulation, Abbeville.

In accordauce with your request I send you the account of the discoveries we made during my last visit.

Although I had returned thoroughly satisfied that the flint axes are really found in situ in the gravel beds (diluvium) at St. Acheul, nevertheless I was extremely desirous of discovering one with my own labor, aud to have other members of the Geological Society of Londou, witness the great discovery you have made. Therefore, I set out ten days ago for Amiens, accompanied by my friends Messrs. R. Godwin Austen, J. W. Flower and R. W. Mylne.* We commeuced work early next morning, and after several hours spent in research and in the

* Mr. R. Godwin Austen, member of the Royal and Geological Societies of London, is the author of important artieles pulblished in the volumes of the Transactions of the Geologieal Society of London. Mr. J. W. Flower, member of the Soeiety of Antiquarians, is known by his papers on Arehaeology, and his fine Geological collection. Mr. R. W. Arylne, member of the Geological and Antiquarian Societies, is known by his great Geological plan of London. 
examination of the deposits at the quarry of St. Acheul, Mr. Flower discovered, and took up, with his own hards, at a depth of twcnty fcet, and at a foot from the surface of the gravel, a very fine axe, wcll cut, and in length about twenty-five centimetrcs. It was from a ferruginous bed, above that of the white gravel, that I obtained the other specimen. Above the gravel there was a bed of sand, containing fresh water and fragile land shclls, and then of brown clay, of gravel, and of brick clay.

The whole was in good order, and nowise deranged. In fact it was very evident that it was a "tcrrain vicrge."

This discovery removed every doubt of my friends, and I believe that now we are all of the same opinion, in regard to the important truth of which you were the first to make the announcement, and which you have sustained for the past ten years-and of which I am happy to be onc of the witnesses.

Accept sir, the assurance of my high regard.

JOSEPH PRESTWICK.

"The conclusions of these eminent gentlemen, membcrs of societics so distinguished, the care that thcy have taken to establish the character of the dcposit and its primitive statc, their profound research, their scrupulous exactness which was carricd so far as even to photograph the excavations, and the deposits in which the axes werc found, and to accept nothing as proof but that which they themselves discovered, and with their own hands drew from the beds and diluvial deposits, should convince the most incredulous.

To M. Boucher de Perthes then, belongs the honor of having first declared that though human bones were not found, yet that the works of man contcmporaneous with the dcluge, ought to exist in the diluvial beds, and of having, after numerous researches, demonstrated the truth of his theory. A truth which Dr. Rigollot, Corresponding member of the Institutc, confirmed in 1854, in his brochure, "Des Instruments en Silex trouves a St. Acheul, and which has just heen again confirmed in a still more authentic manner by the learncd English Geologists, whose names we have just mentioned; to which we must add that of the celcbrated Palæontologist, Falconer, Vice President of the Geological Society of London, who, in 1858, visited Abbéville, and there examined with great carc, the rich collection of M. Boucher de Perthes; and also that of Mr. John Evans, member of the Geological and Antiquarian Societies of London, and another of several mcmoirs on Archæology and Numismatology, in a letter from whom, addressed to our President, we read- "I was present at the sitting of the Royal Socicty, when Mr. Prestwick read his report on the stone axcs found in the diluvium, and I add my testimony to his." After spcaking of the axe that his collcague had just discovered in the diluvium, in Suffolk, Mr. Evans, who had accompanied Mr. Prestwick in his first visit to Abbéville, and assisted him in his explorations, says-'I am satisfied these instruments of flint will be found in many other localities if the search for them be properly conducted.'”

\section{LETTER FROM PROFESSOR AGASSIZ.}

KEY WEST, Feb. 25th, 1858.

Prof. F. S. Holmes:

MY DEAR SiR:-I have not forgottcn my promise to write you my impressions respecting your important discoveries of fossil mammalia in the Post-Plciocene beds of South-Carolina. Indecd, I have been thinking of them continually since I saw them, and nothing impressed me so deeply for many years past as the sight of these bones. I consider their careful study in all their relations as of the utmost importance for the progress of our science. It is true there is hardly anything of interest in the animals themselves, since they appear to be all well known types, but their simultaneous occurrence in the same beds showing that they have lived together at a timc when the white man had not yet planted himself upon this continent, render their association 
as undisputed. How does it happen, that horses, sheep, bulls and hogs, not distinguishable from our domestic species, existcd upon this continent, together with the deer, the musk-rat, the beaver, the hare, the opossum, the tapir, which in our days are peculiar to this continent, and not found in the countries where our domesticated animals originated? The whole matter might scem to admit of an easy solution by supposing that the native American horse, sheep, bull, and hog were different species from those of the old world, even though the parts preserved show no specific differences; but this would be a mere theoretical solution of a difficulty which seems to me to have far deeper meaning, and to bear directly upon the question of the first origin of organized beings.

The circumstances under which these remains are found, admit of no doubt but the animals from which they are derived, existed in North America long before this continent was settled by the white race of men together with animals wlich to this day are common in the same localities, such as the deer, the musk-rat, the opossum, and others only now found in South America, such as the tapir. This shows beyond the possibility of a controversy, that animals which cannot be distinguished from one another, may originate independently in different fauna, and I take it that the facts you have brought together, are a satisfactory proof that horses, sheep, bulls, and hogs, not distinguishable at present from the domesticated species, were called into existence upon the continent of North America prior to the coming of the white race to these parts, and that they had already disappeared here when the new comers set foot upon this continent; but the presence of tapir teeth among the rest show also that a genus peculiar to South America and the Sunda Islands, existed also in North America in those days, and that its representative of that period is not distinguishable from the South American species.

It would be desirable in this stage of the enquiry to compare your tapir teeth with those of the species from Central America, which is considered distinct from the Brazilian species. This circumstance leads naturally to the question of the specific identity of all these animals with those now living in the same locality, and with the domesticated species. And here I confess the difficulty to be almost insuperable, or at least hardly approachable in the present state of our science, when the views of naturalists are so divided as to what are specics among the genera bos, ovis, capra. For myself, I entertain doubt respecting the unity of origin of the domesticated horses. But whatever be the final result of this enquiry, this much is already established by the fossils you have collected, that horses, hogs, bulls and sheep were among the native animals of North America, as early as the common American deer, the opossum, the beaver, the musk-rat, etc. What remains to be settled respecting their specific identity, is involved in the controversy now carried on between naturalists, who admit specific distinctions upon a very wide range of differences, and those who limit them within narrow boundaries. But the final solution of this point can in no way lessen the interest of your discoveries.

Should you publish anything upon ihis subject, let me have your notice, for I am deeply interested in the subject, as I always shall be, in everything you do.

Ever truly your friend,

L. AGASSIZ.

The result of the whole seems to be, that of the animals found fossil in the Post-Pleiocene beds, all the mollusca of the present day are undoubtedly a perpetuation of the same species; that of the higher order of vertebrata, the tapir, peccary, raccoon, opossum, deer, elk, and musk-rat are equally entitled to be considered the descendants of this ancient race. And if the claims of the mollusca to this distinction rests upon a secure basis, because they are peculiar to this country and not obnoxious to suspicion of foreign immigration, it must be recollected that this is equally true of the above named animals. 
Those which have hitherto been regarded as of recent and European origin, are the horse, sheep, hog and ox; and it must be reserved perhaps for future consideration to determine how far the negative proof of the non-existence of these animals in the country at the time of its discovery may be regarded in each individual case sufficiently strong to settle the question of his extinction and re-introduction, when so many of his associates and contemporaries have succeeded in maintaining an unbroken line of descent down to the present day. 


\section{N D E X.}

A.

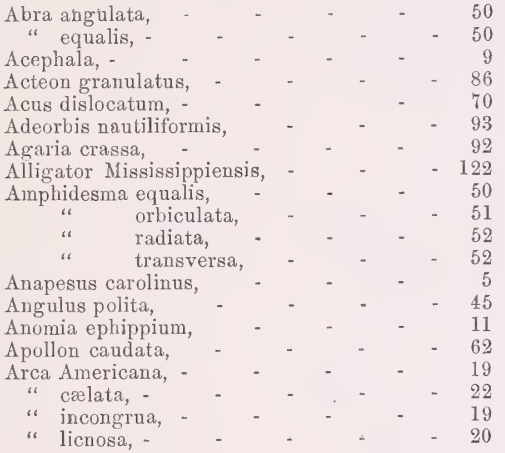

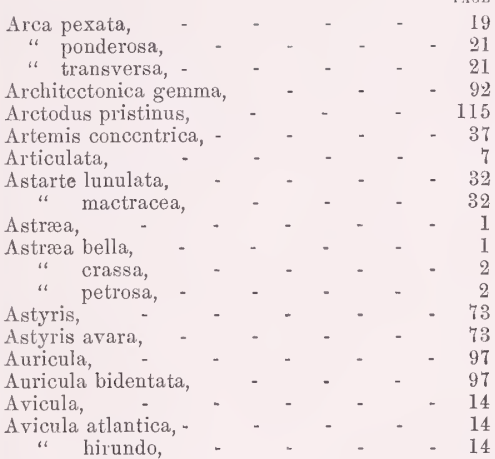

Balanoidea,

Balanus,

Balanus eburncus, - $\quad$ - $\quad$ - $\quad$ - 7

Barricuda, - $\quad$ - $\quad$ - $\quad$ - 120

Bison latifrons, _ _ _ _ _ $\quad$ - 109

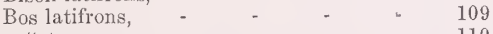

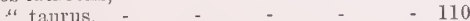

Bowman, Major, collection of fossils, - 99

Bryozoa, - - - - - $\quad 6$

Buccinis ampullaceis tenuibus, - _ 67

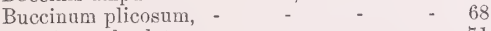

" obsoletum,

B.

Buccinum lunatum, _ _ _ _ 74

$\begin{array}{llll}\text { "Nov. Eboracensis, } & & & \\ \text { " } & 71 \\ \text { " ad sinistram convolutis, } & - & & 65 \\ & \text { ampllaceum } & & \end{array}$

Bulla obstricta, - $\quad$ - $\quad$ - $\quad$ - $\quad 78$

" canaliculata, - $\quad$ - $\quad$ - 78

" pyrum, - $\quad$ - $\quad$ - $\quad$ - 67

Bullina canaliculata, - _ _ _ $\quad$ - 78

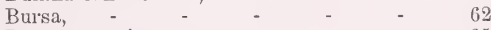

Busycon carica, - $\quad$ - $\quad$ - $\quad$ - 65

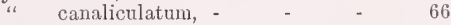

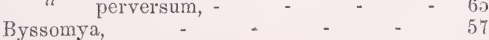

C.

Calappa mormorata, - $\quad$ - $\quad \begin{array}{r}6 \\ \text { - }\end{array}$

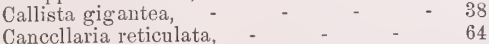

$\begin{array}{ccccc}\text { Canccllaria retieulata, - } & - & & & \\ \text { " } & - & & 64 \\ \text { Venusta, } & - & & 64\end{array}$

Canis familiaris, - _ _ _ _ 116

Capybara, - _ _ _ _ $\quad$ - 112

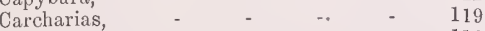

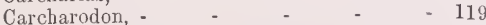

Cardita Floridana, $\quad$ - $\quad$ - $\quad 3 \quad 32$

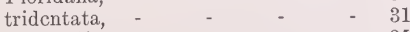

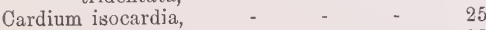
lævigatun, - $\quad$ - $\quad$ - $\quad$ -

Cardium maculatum, - _ _ _ $\quad 23$

" magnum, - * - $\quad$ - $\quad 23$

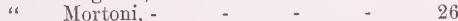

" muricatum, - $\quad$ - $\quad$ - $\quad$ - 24

" sublineatum, - $\quad$ - $\quad$ - $\quad 26$

" ventricosum, - $\quad$ - $\quad$ - 23

Cassidulus pyrun, $\quad$ - $\quad$ - $\quad$ - 67

Castoroides Ohioensis, _ _ _ _ _ $\quad$ - 114

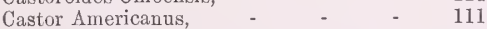

" Canadensis, - $\quad$ - $\quad$ - $\quad 111$

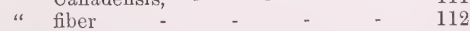

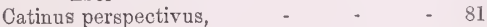




\section{C.-continued.}

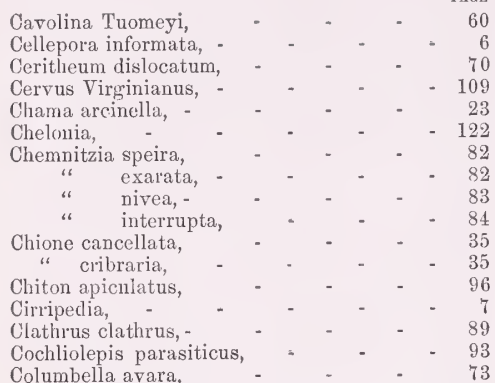

PAGE

Columbella lunata, _ _ _ _ $\quad$ - 74 " ornata, _ _ _ . $\quad 74$

"spirantha, - $\quad-\quad-74$

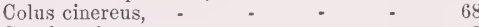

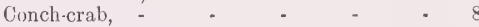

Corbula contracta, - $\quad$ - 50

Crepidula aculeata, - _ _ _ _ $\quad$ - 95

" fornicata, - . $\quad$ - 95

Crepipatella aculeata, $\quad$ - $\quad$ - $\quad$ - 996

Crustacea, - . _ _ _ _ - 7

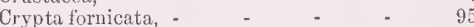

Cryptostoma perspectiva, $\quad$ - $\quad$ - $\quad$ - 81

Cumingia tellinoides, . $\quad$ - $\quad$ - 53

Cypricardia Floridana, _ _ _ - $\quad$ - 32

Cyrena Carolinensis,

Cytherea gigantea, - $\quad$ - $\quad$ - $\quad$ - 36
Dactylidia mntica,

Dactylina oblongata, -

Decopoda, -

Delphinula,

$-1-5-92$

Description vertebrata. - $\quad$ - $\quad 999$

Dicotyles fossilis, - $\quad$ - $\quad-108$

Echinidæ,

Echinodermata,

Echinus variegatus,

Edentata,

Elephas Americanus, . 108

$\begin{array}{lr} & 108 \\ 53\end{array}$

Equus Americanus, . . . 100

Fasciolaria gigantea, . . . . $\quad 63$

" distans, . . . . 63

Fiber zibethicus, - . . . 113

Fissurella alternata, . . . . . 94

Foraminifera, 1

Fulgur carica,

"canaliculata, . $\quad 66$

" pyrum, . . . . 67

Galeocerdo,

Gnathodon cuneatus, Grayii,

Harlanius, - $\quad$ - $\quad$ - $\quad$ - $\quad$ - 110

Harlanus Americanus, - $\quad$ - $\quad$ - 110

Helisuma lentus,

Hipparion venustum,

D.

Dicotyles tibiatus, $\quad$ - $\quad$ - $\quad 108$

" compressus, $\quad$ - $\quad$ - $\quad$ - 108

Didelphys Virginiana, - $\quad$ - $\quad$ - $\quad 116$

Donax variabilis, - $\quad$ - $\quad$ - 49

Dosinia concentrica, $\quad$ - $\quad$ - $\quad$ - 37
Equus complicatus, . $\quad . \quad$. 100

" fraternus, . . . . 100

" major, . 100

Eubradys antiquus, . . . 111

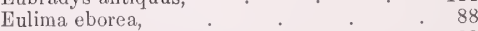

" conoidea, . 88

" c olencen

$\begin{array}{ll}\text { " oleacea, . . . . . } & 88 \\ & 88\end{array}$

Eupleura caudata $\quad 62$

F.

Fulgur pyruloides, . . . . $\quad 67$

Fusus bullata, $\quad$. 69

" cinereus, . . . . 68

" conus, . . . . 69

" filliformis,

" minor, , . . . 68

" rudis, . . 70

G.

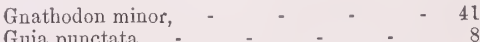

H.

Hippotherinm Genus, - - - 105

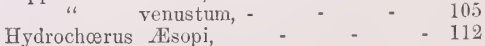

" capybara, - . - . 
I.

Ischyrbiza mira. - - $\quad$ - $\quad$ - 120

Ischyrhiza antiqua,

L.

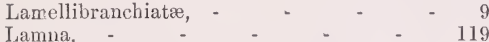

Lævicardium serratum, _ _ _ $\quad$ - 25

Lavignon tellinoides,

Leida limatula, $\quad$ - $\quad$ - $\quad$ - $\quad 18$

Lcidy, Prof. verteb, fossils, - $\quad$ - $\quad 99$

Lcpidosteus bison, - _ _ $\quad$ - 118

Lepus sylvaticus, - $\quad$ - $\quad$ - $\quad$ - 113

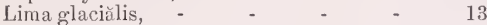

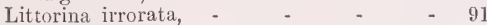

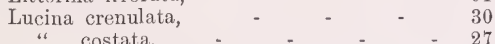

" divaricata, $\quad$ - $\quad$ - $\quad 27$

“ Kiawahensis, - $\quad$ - $\quad$ - 29

$\begin{array}{lllll}\text { “ multilineata, } & - & - & - & 29\end{array}$

“ radians, - $\quad$ - $\quad$ - $\quad$ - 28

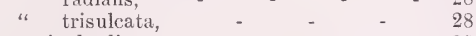

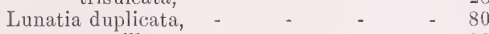

" pusilla, - $\quad$ - $\quad$ - $\quad$ - 80

Lunulites denticulata, $\quad-\quad$ - $\quad$ - 6

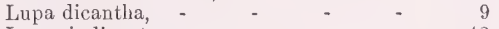

Lutraria lineata, _ $\quad$ - $\quad$ - $\quad$ - $\quad 42$

" canaliculata, - - $\quad$ - 43

M.

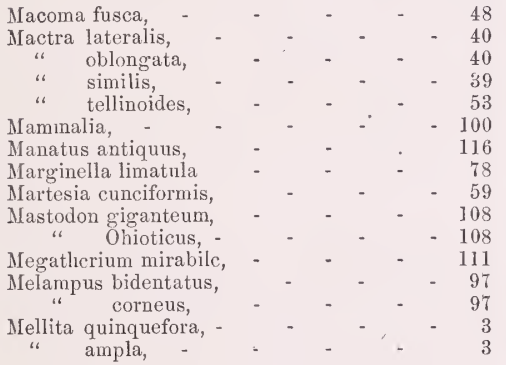

Mercenaria notata, - $\quad-\quad$ - $\quad$ - 34

" Mortoni, - - $\quad$ - 34

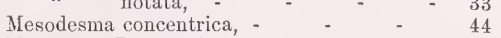

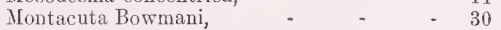

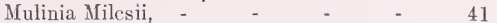

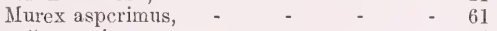

" carica, - . $\quad$ - $\quad . \quad 65$

“ canaliculata, - $\quad$ - $\quad$ - $\quad$ - $\quad$ - 66

“ spinacosta, - $\quad$ - $\quad$ - $\quad 61$

" spinacostatus, $\quad$ - $\quad \ldots \quad$ - $\quad 61$

Mya arenaria, - $\quad$ - $\quad$ - $\quad$ - 55

" acuta, - $\quad$ - $\quad$ - $\quad$ - $\quad$ - 55

" simplex, - . - - $\quad$ - 55

Mylodon Harlani, - $\quad$ - $\quad$ - $\quad$ - 111

N.

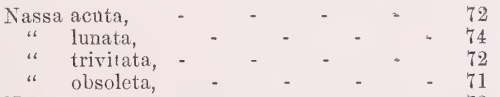

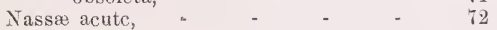

Natica duplicata, -
"
Nosilla, -

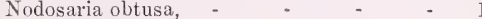

Nucula acuta, - $\quad$ - $\quad$ - $\quad$ - $\quad 15$ proxima, $\quad-\quad-\quad-\quad-17$

O.

Obeliscus crenulatus, . $\quad$. $\quad 88$

Odostomia granulatus, _. . . $\quad 86$

Oliva litcrata, . . . . . 75

" mutica,. . . . $\begin{array}{r}76 \\ 112\end{array}$

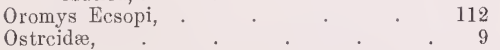

Ostrea fundata, . . . . . 11

"Virginiana, . . . . 10

" " var procyon, . . 10

"Virginica, . . . 9

Ovis ammon, . . . . $\quad 110$

Orula acicularis, . .79

P.

Pachydermata, . . . . 106

Pasithea exarata, . . . 82

Pastinaca hastata, . . . . $\quad 119$

Patella fornicata, . . . . 95

Pecten dislocatus, $\quad$. $\quad$. $\quad$. 12

" purpuratus, . . . . . 12

Pectunculus Oarolinensis,

Pcctunculus Charlestonensis, _ . 16

Pcronæa tenta, . . . . 46

Peronæaderma altcrnata, . . . . 45

Petricola pholadiformis, . . . $\quad 38$

" fornicata, . . . . 38

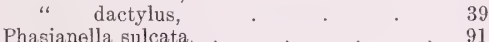




\section{P.-continued.}

Pholas costata

PAGE

" cuneiformis,

" oblongata,

" truncata,

Physeter antiquus,

Pinna muricata,

" seminuda,

Planorbis lentus,

Pleurotoma cerinum,

Plicatula cristata

Polyparia,
Porcellana limatula,

Procyon lotor

Pseudocarcinus mercenaria,

Psammobia cayennensis,

Pteropoda

Pyrula carica,

" perversa,

" canaliculata

" spirata,

" pyrum
PAGE

78

115

8

47
48

65

65

66

67

R.

Raeta canaliculata, - $\quad$ - $\quad$ - $\quad$ - 42

" lincata,

" papyracea

Ranella caudata,
S.

Sanguinolaria fusca, -

Saxicava fragilis, -

Scalria angulata,

" clathrus,

" lineata,

" multistriata,

Schizaster atropos,

Seutella quinquefora,

Sea-crab,

Semele orbiculata,

" radiata, transversa

Serrula variabilis,

Siliquaria gibba

solarinin caribcea,

Solen caribceus,
Rangia cyrenoides, - - - $\quad$ - 41

Teptocelleporaria informata, - $\quad-\quad r 6$

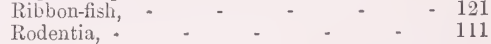

Solen constrictus, $\quad$ - $\quad$ - $\quad$ - $\quad$ - $\quad$ - 47

" curvus, - $\quad$ - $\quad$ - $\quad 53$

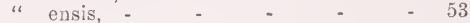

Solecurtus caribœus, $\quad$ - $\quad$ - $\quad$ - 54

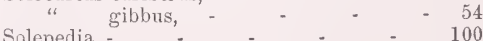

Spatangus atropos, - _ _ $\quad$ - 5

Sphyræua barricuda, $\quad$ - $\quad$ - $\quad$ - $\quad 120$

Sphyrænoid fish _ - _ _ _ _

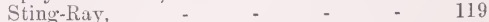

Stone crab, - $\quad$ - $\quad$ - $\quad$ - $\quad$ - 8

Strephona literata, _ _ _ _ _ _

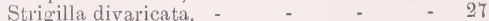

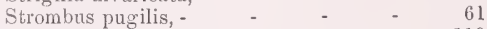

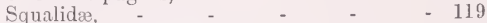

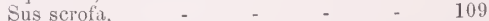

"Americanus, - $\quad$ - $\quad$ - $\quad$ - 110

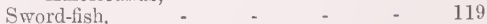

T.

Tapes grus, - $\quad$ - $\quad$ - $\quad$ -

Tapir, -

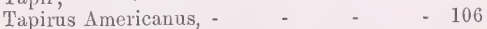

" Haysii, - $\quad$ - $\quad$ - $\quad$ - 106

Tellidora lunulata, - $\quad$ - $\quad$ - $\quad-47$ $-\quad-\quad-\quad-47$

Tellina alternata, - $\quad$ - $\quad-\quad$ - 45

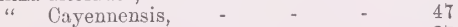

" divaricata, - $\quad$ - $\quad$ - $\quad$ - 27

" f fusca,

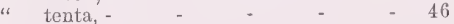

" interstriata, - $\quad$ - $\quad$ - 47

“ flexuosa, - $\quad$ - $\quad$ - $\quad 44$

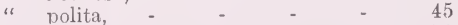

Terebra dislocata, - $\quad$ _ $\quad$ _ $\quad$ - 70

"Carolinensis, $\quad$ - $\quad$ _ $\quad 50$

Teredo palmulatus, - $\quad$ - $\quad$ - $\quad$ - 60

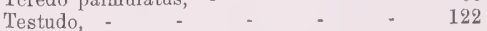

Tetracaulodon, $\quad$ - $\quad$ - $\quad$ _ $\quad$ - 108

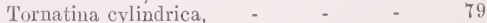

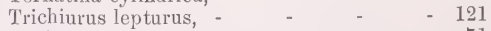

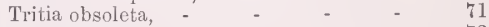

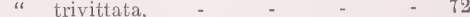

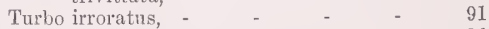

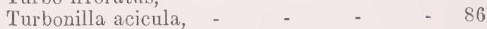

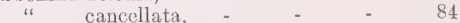

“ Caroliniana, - $\quad$ - $\quad$ - 86

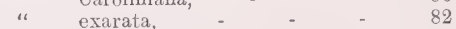

" interrupta, $\quad$ - $\quad$ - $\quad-83$

“ lineata,

" nivea, - $\quad$ - $\quad$ - $\quad-\quad 53$

" speria, $\quad$ - $\quad$ - $\quad$ - 82

" subcoronata, - $\quad$ - $\quad-87$

" subulata, $\quad$ - $\quad$ - $\quad$ - 85

" quinque-striata, - - - $\quad 85$

Turritella interrupta, _ _ _ _ $\quad$ - 83 
U.

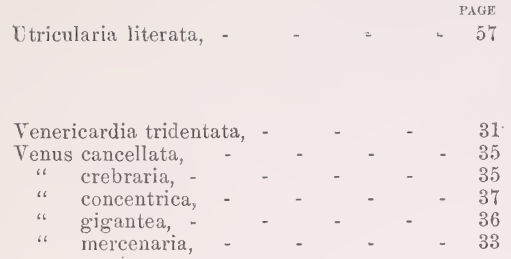

V.

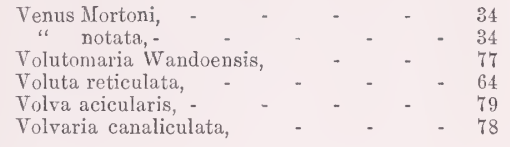

X.

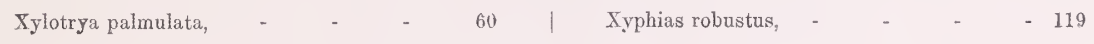




\section{ERRATA.}

In reference to Plate XVII, second line, instead of form, read four molar teeth.

In reference to Plate XIX, at fig. 2, for fifth molar tooth, read fourth molar tooth.

In reference to Plate XX, fig. 9, read Bos taurus before the words, last lower.

At page 113 , in reference to figures of F1BER ziBEThecus, for figs. 1 to 4 , read figs. 2 to 4 . 


\title{
POST-PLEIOCENE FOSSILS.
}

\author{
F 0 R A M IN IFERA. \\ Genus, NODOSARIA.-LaMr. \\ N O D O SARIA O B T USA.-(New Species.)
}

Plate I. Fig. 1.

Description. Shell elongated, sub-cylindrical, with twenty-two longitudinal, obtuse and flattened ribs; loculi six, convex; aperture round, margin raised and prominent; length, one-fourth of an inch.

This is the only specimen of a Nodosaria yet discovered in the Post-Pleiocene of South-Carolina. In the Eocene marls of the State, it is common.

Plate I. Fig. 1, Magnified.

Locality. Simmons' Bluff, Young's Island.

Cabinet F. S. H.

\author{
P OLYPARIA.

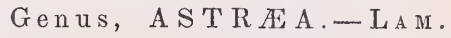 \\ A S TRAA B E L L A. \\ Plate I. Fig. 2.
}

Astræa bella, Conrad, Jour. Acad. Nat. Sci., Vol. 8, p. 189.

Astræa bella, Tuomey \& Holmes, Pleiocene Fossils So. Ca., p. 1, pl. 1, fig. 1.

Description. Stars often polygonal, sometimes circular, deep, lamellar; lamellæ numer- 
ous, alternately larger and smaller, denticulated and rough on the edges, sides prominently papillated; partitions between the stars thin and plaited by the alternate position of the lamellæ of the adjacent stars.

This coral was first described by Mr. Conrad, from a fossil specimen found near Newbern, North-Carolina. It is common in the recent state on this coast and often incrusting other bodies.

Plate I. Fig. 2. Museum, College of Charleston; Cabinet F. S. H.

A S T R $A$ C R $\Lambda$ S S A. - (New Speeies.)

Plate I. Figs. 3 and $3 a$.

Description. Corallum thick, not incrusting; stars orbicular, sometimes polygonal, irregular, deep; lamellæ about twelve, rough, denticulated.

The cells of this coral resemble A. MarYLANDica, of Conrad; but, unlike that species, it is thick and not incrusting.

Plate I. Fig. 3, Coral, natural size.

" $3 a$, Cell, magnified.

LOCALITY. Charleston.

Cabinet F. S. H.

\section{$\Lambda \mathrm{STR} A \quad \mathrm{PETROS} \Lambda$. \\ Plate I. Figs. 4 and $4 a$.}

Astræa petrosa, Dana, Zoophytes, U. S. Exploring Expedition, Vol. 8, p. 238.

Description. "Convex; corallum sub-cellular, firm; in a transverse section the stars orbiculate, commonly oblong, one-and-a-half to three lines broad and one-and-a-half to five lines long; many-rayed, rays very thin, with the cellules simple; septa a line thick and quite solid."-Dana.

This fragment, of which we have given an outline in Plate I, Fig. $4 a$, with a drawing of 
four cells, was kindly presented me by Mr. Allen S. Hanckel, who discovered it in St. Andrew's Parish, near Charleston. A. PETros A is a West India coral.

Plate. I. Fig. 4, Cells, natural size.

" $4 a$, Outline of fragment.

Locality. St. Andrew's.

Cabinet F. S. H.

Class, ECHINODEMATA. Order, ECHTNI. Family, ECHINID无.

Genus, MELLITA.-KLEIN.

MEL L T A Q U I Q U E F O R A. Variety, AMPLA.

Plate I. Figs. $6,6 a$ and $6 b$.

Scutella quinquefora, Lamk., An. sans Vert., Vol. 3, p. 280.

Scutella quinquefora, Ravenel, Cat. Recent and Fossil Echinidæ So. Ca., 1848, p. 4, No. 7.

Mellita ampla, Holmes, MS.

Mellita ampla, Ravenel, Cat. Recent and Fossil Echinidæ So. Ca., 1848, p. 4, No. 8.

Scutella quinquefora, L. R. Gibbes, Tuomey's Geol. So. Ca., appendix, p. xxiii.

Description. Disk sub-orbicular, truncated posteriorly; margin thin, slightly notched opposite anterior ambulacrum; upper surface moderately convex; lower surface flat, or slightly convex; lunules five, open, long and narrow; posterior lunule wider and about one-fifth longer than the ambulacral petals, sub-ovate, open; posterior pair longer than the anterior or lateral petals; ambulacral furrows on lower surface deep, branched; branches dendritic.

This shell was, ten years ago, referred with some hesitation to a new species, and called M. ampla, on account of its great size. 'We now feel quite assured it is only a large variety of Mellita quinquefora, Rav. The conditions for so great development, which existed during the Post-Pleiocene period, have passed away with that age ; and were probably owing to the gulf stream washing the shores of South-Carolina before the upheaval of our low country. Individuals of the present period, now living in the waters of the coast, seldom attain one-half the size of their fossil congeners. It is also worthy of remark, that few small specimens, or young shells of this species, are found in a fossil state, though large ones are abundant. 
We retain the characteristic specific name AMPLA for this variety, which was suggested by our friend, Prof. Agassiz, and give in the plate, fig. 6, a good figure of this magnificent MELlita, surrounding it with an outline $(6 a$.) of the largest specimen yet discovered.

Plate I. Fig. 6, Vien from above.

" $6 a$, Outline of largest specimen in the cabinet.

" 6b, Profile of same.

Locality. Simmons' Bluff, St. Paul's:

Museum, College of Charleston; Cabinet F. S. H.

\section{E CHINUS VARIEGATUS.}

Plate II. Fig. 1.

Echinus variegatus, Lam., An. sans Vert., 2d Ed., Vol. 3, p. 365.

Echinus variegatus, Say, Jour. Acad. Nat. Sci., Vol. 5, p. 226.

Echinus variegatus, L. R. Gibbes, Tuomey's Geol. So. Ca., appendix, p. xxiii.

Description. Shell, orbicular, sub-globose, the large tubercles extend in rows from basal to dorsal aperture; lower surface, or base, closely covered with rows of large mammaliferous tubercles, varying slightly in size; plates studded with small tubercles, giving the shell a beautiful granulated appearance; the pores in the series of ambulacral bands are placed alternately two and four, and the rows slightly inclined; aperture for the mouth large, circular, with ten fissures or clefts, which are narrow, deep and slightly curved; dorsal aperture irregular; spines short, and numerous, the larger ones subtruncated at their points; a few spatula-like spines surround the mouth.

This species is living in deep soundings off the Carolina coast, and is known as the short-spined sea urchin, or bachelor's button. Like its congener, only one specimen in a perfect state has, as yet, been obtained from the Post-Pleiocene; the fragments and spines are numerous.

Plate II. Fig. 1, Shell, natural size, viewed from above.

" 1 a, Spines.

Locality. Simmons' Bluff, St. Paul's; Charleston.

Museum, College of Charleston; Cabinet F.S.H. 
$\Lambda$ NAPESUS C A ROLINUS.

Plate II. Fig. 2.

Anapesus Carolinus, Troschel.

Echinus punctulatus, Lam., An. sans Vert., 2d Ed., Vol. 3, p. 363.

Echinus punctulatus, L. R. Gibbes, Tuomey's Geol. So. Ca., appendix, p. xxiii.

Echinus punctulatus, Ravenel, Cat. Recent and Fossil Echinidæ So. Ca., p. 1.

Descrittion. Disk orbicular; upper surface convex, often sub-conical; ambulacral plates, with two purple bands of pores in pairs, extending from basal to anal aperture, having one row of large tubercles on each side; the interambulacral spaces on the dorsal part of the shell without tubercles, or the fine granules which cover the plates around their base ; the sutures of the angular plates distinct ; dorsal aperture oval ; spines aciculariform, with purple points; those on the base spatulariform.

This fragile shell is seldom obtained in a perfect state from the Post-Pleiocene beds, and never with the spines attached; the specimen from which our figure is taken was procured from excavations made for the tidal drains in the upper part of the city of Charleston, and kindly presented to me by Dr. Wm. T. Wragg, the Alderman under whose superintendance the work was done. Fragments of the shell, and perfect spines, are often found in the sands of the Post-Pleiocene. It is the most common species now living upon the Carolina sea-coast.

Plate II. Fig. 2, Shell, natural size, vieved from above.

" $2 a$, spine of the same.

Locality. Charleston; Simmons' Bluff, St Paul's; Wando.

Museum, College of Charleston; Cabinet F. S. H.

Genus, SCHIZASTER.-Agassiz.

SH I Z S T E R A T ROPOS.

Plate II. Fig. 3.

Spatangus atropos, Lam., An. sans Vert., 2 d Ed., Vol. 3, p. 327.

Spatangus atropos, L. R. Gibbes, Tuomey's Geol. So. Ca., appendix, p. xxiii.

Schizaster atropos, Ravenel, Cat. Recent and Fossil Echinidæ of So. Ca., p. 4, No. 16.

Only a small fragment from the left anterior portion of this shell has been found in the 
Post-Pleiocene, but it is sufficiently characteristic to determine the species to which it belongs. S. ATropos is found along the Carolina coast in a recent state.

Plate II. Fig. 3, Fragment, and restored outline of shell, natural size.

Locality. Abbapoola Creek, John's Island. Museum, College of Charleston.

\author{
BRYOZOA. \\ Genus, REPTOCELLEPORARIA.-D'Orв.
}

REP T O C E L L E P O R A R I A I N F O R M $A$ T $\Lambda$.

Plate I. Fig. 5.

Cellepora informata, Lons., Quar. Jour. Geol. Soc., London, Vol. 1, p. 505.

Reptocelleporaria informata, Tuomey \& Holmes, Pleiocene Foss. So. Ca., p. 15, pl. 4, figs. 11 and 12 .

Description. Incrusting, irregular; surface porous, mammillary; cells unequal; mouth circular, raised, thickened.

This little coral is easily known by its densely porous surface. Our figure represents a fragment of Ostrea, incrusted with irregular laminæ of this pretty species; the cells are barely visible without a lens.

Plate I. Fig. 5, Fragment of Ostrea, incrusted with this Bryozoa.

Locality. Charleston.

Cabiniet F. S. H.

\title{
Genus, LUNULITES.-LAM.
}

L U N U L I T E S D E N T I C U L $A$ T $A$.

Plate II. Figs. $4,4 a$ axd $4 b$.

Lunulites denticulata, Con., Am. Jour. Sci., Vol. 41, p. 348.

Lunulites denticulata, Lons., Quar. Jour. Geol. Soc., London, Vol. 1, p. 503.

Lunulites denticulata, Tuomey \& Holmes, Pleiocene Fossils So. Ca., p. 11, pl. 4, fig. 1.

Description. Shell sub-conical, depressed; interior surface radiate, striated, granulated, 
or punctate; cells oblong, denticulate, quincunx; mouths circular, or semi-circular; margin crenulated.

This is a very abundant species in the Post-Pleiocene marls and sands, and is identical with one living on the coast.

Plate II. Fig. 4, Shell, magnified.

" 4a, Profile, natural size.

" $4 b$, Outtine of base.

Locality. Simmons'; Abbapoola; St. Andrew's.

Museum, College of Charleston; Cabinet F. S. H.

\author{
A R T I C U L A T A.

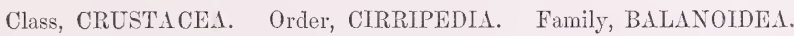 \\ Genus, BALANUS.-BRug. \\ B $A$ L A U S EB UR N E US. \\ Plate II. Figs. 5 aNd $5 a$. \\ Balanus eburneus, Gould, Invert. Mass., p. I5, fig. 6. \\ Balanus eburneus, De Kay, New-York Fauna, part 5, p. 252, pl. 35, fig. 320. \\ Balanus eburneus, L. R. Gibbes, Tuomey's Geol. So. Ca., appendix, p. xviii.
}

Description. Shell white, smooth, obliquely conical; the raised triangles, with lanceolate points, all inclined backwards; within, regularly grooved.-Gould.

A large number of specimens are found in the Post-Pleiocene beds of South-Carolina, and although the above description does not exactly apply to all the varieties, we consider them specifically identical. It is a common species in Charleston harbor.

Plate II. Figs. 5, and 5a.

Locality. Simmons'; Wadmalaw Sound; Abbapoola Creek, John's Island.

Museum, College of Charleston; Cabinet F. S. H. 
Order, DECOPODA.

See Fauna of South Carolina, appended to Tuomey's Geology of that State, by Prof. L. R. Gibbes, p. xv.

\author{
CALAPPA IIARMORATA.-FAB. \\ Plate II. Fig. 6. \\ Vulgo, Box or Conch-Crab.
}

We have only a fragment (the movable finger) of the right claw of this beautiful species of Crab, from the Post-Pleiocene marls, but it is so characteristic as to dissipate all doubt of its existence during that geological period. Calappa marmorata is living on the coast of South-Carolina, in deep water, but is rarely captured.

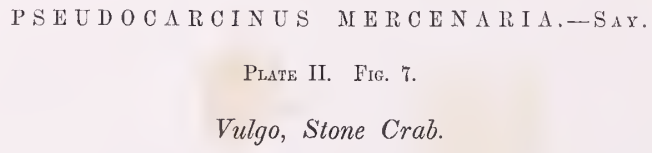

Our figure is taken from a fragment of the lower finger of left claw; the punctured groove along the side is quite characteristic. This also is a common species in the waters of our bays and harbors.

\footnotetext{
GUIA PUNCTATA.-BROWN.

Plate II. Fig. 8.

Vulgo, Little-spotted Crab.
}

The third joint of the right claw is all of this species yet found in the Post-Pleiocene. It is a common crab upon the coast. 
L U P A D I C A N TH A. - LAT.

Vulgo, Sea Crab, [not figured.]

Since our plate was drawn, several fragments of this species have been found. It is the common edible crab, found living along the coast from Florida to Cape Cod.

The five species of above-named decopodous crustaceans were all discovered in the sandy beds of Post-Pleiocene age, at Mr. Simmons', Wadmalaw Sound.

Museum, College of Charleston; Cabinet F. S. H.

Class, ACEPhaLA. Order, LAMELLIBRANCHIATA. Family, OSTREID A.

Genus, OSTREA.-Linn.

O S T R E A I R G I I A N A.

Plate II. Fig, 9.

Ostrea Virginiana, Lister, Conch, t. 200, f. 34

Ostrea Virginiana, Sowerby, Genera of Shells, fig. 2.

Ostrea Virginiana, Conrad, Foss. Shells Tert. Formation, Vol. 1, p. 28, tab. 14, fig. 2.

Ostrea Virginiana, Gould, Invert. Mass., p. 136.

Ostrea Virginiana, L. R. Gibbes, Tuomey's Geol. So. Ca., appendix, p. xxii.

Ostrea Virginiana, Tuomey \& Holmes, Pleiocene Foss. of So. Ca., p. 20, pl. 5, figs. 6 to 9.

Ostrea Virginica, Gmelin, Syst., 3336, No. 113.

Ostrea Virginica, Dillwyn, Catal., 1, 277.

Ostrea Virginica, Lam., An. sans Vert., VII., 225.

Ostrea Virginica, Wood, Index, pl. 2, fig. 68.

Ostrea Virginica, Deshayes, Ency. Meth. Vers. II., pl. 179, figs. 1 and 2.

Ostrea Virginica, Ravenel, Cat. Coll. Shells, p. 8.

Ostrea Virginica, DeKay, Zoology New-York, Art. Mollusca, p. 169.

\section{Vulgo, Virginia Rock Oyster.}

Description. Shell irregular, ovate-oblong, thick; lower valve radiately plicate, 
rugose, or radiately undulating; superior valve smaller, somewhat flat, lamellar or plicate; muscular impression nearly central; hinge with deep channel in lower valve, and cor1esponding eminence in the upper, extending to apex of shell.

It is exceedingly variable in form and character, both in a fossil and recent state.

Notwithstanding its great abundance in the recent state along our shores, it is by no means a very common shell in the Post-Pleiocene. In the Pleiocene it is a rare fossil.

The long and narrow variety is known on the Carolina and Georgia coasts, as the Racoon Oyster, and is described in the next article.

Plate II. Fig. 9, Interior of lower valve, natural size.

Locality. Charleston; Simmons', Young's Island; Brown's, St. Andrew's; Ashley Ferry.

Museum, College of Charleston, Cabinet F. S. H.

OSTREA VIRGINIANA. Variety, PROCYON.

Plate II. Fig. 9a.

Vulgo, Raccoon Oyster.

Description. Shell narrow, greatly elongated, seldom curved, gradually widening from the beak or apex to the other extremity which is rounded; ligamental fossa long and deep; cavity often extending under the hinge in lower valve; its other characteristics are the same as described above in O. Virginiana.

In a recent state, it is a very common shell along the bays and shallow inlets of the coast of South-Carolina; its elongated, narrow form, is due to its position, growing vertically, and in crowded clusters. Individuals are frequently found measuring ten or twelve inches in length, but seldom over one-and-a-half or two inches in breadth. Beds of this species are often exposed at half-tides, at the mouths of rivers and creeks; on the mud-flats they abound. The Raccoon (Procyon lotor) resorts to these places upon the first flow of the tide, when the mouths of the Oysters are all opened ready for the refreshing influence of the young flood-tide; quickly and skilfully, by a thrust of his paw, he extracts from the shell his favorite food; hence the name, "Raccoon Oyster."

In the Pleiocene marls of our State, we have found this variety fossil, but it is rare. Only a few specimens have been discovered in the beds of Waccamaw and Goose Creek; and though not abundant in the Post-Pleiocene, it is not uncommon.

"The genus Ostrea had its beginning in the Triassic, was very numerous in the Jurassic, Cretaceous and Tertiary periods, and has its numerical maximum in the present 
seas, where it exists at all depths, generally within the limits of tide water, but frequently within deeper soundings." $-T$. \& $H$.

Plate II. Fig. 9a., Exterior of lower valve.

Locality. Charleston; Simmons', Young's Island.

Museum, College of Charleston; Cabinet F. S. H.

\section{A NOMIA EPHIPPIU M.}

Plate II. Frg, 11.

Anomia Ephippium, Linn, Syst. Nat., 1150.

Anomia Ephippium, Conrad, Foss. Ter. Form., p. 75, pl. 43, fig. 4.

Anomia Ephippium, Ravenel, Cat. Coll. Shells, p. 8.

Anomia Ephippium, Gould, Invert. Mass., p. 138.

Anomia Ephippium, De Kay, Zool. New-York, Art. Mollusca, p. 168.

Anomia Ephippium, L. R. Gibbes, Tuomey's Geol. So. Ca., appendix, p. xxii.

Anomia Ephippium, Tuomey \& Holmes, Pleiocene Foss. So. Ca., p. 18, pl. 5, fig. 4 and 5.

Description. Shell translucent, orbicular, irregular, undulating, concentrically striated or smooth; lower valve fragile; opening for the bysus, large, oval.

This is an abundant shell of the Pleiocene and Post-Pleiocene periods; the upper, or left valve, is very common upon the sea-beaches of the coast; the lower valve, through which the plug of cartilage passes, is seldom obtained in a fossil state. The recent shell is found attached to drift wood, shells and rocks.

Plate II. FIg. 11, Left valve, natural size.

Locality. Simmons', Wadmalaw Sound; Abbapoola Creek, John's Island.

Museum, College of Charleston; Cabinet F. S. H.

\section{O S T R E A F U N D A T $\Lambda$.}

Plate II. Fig. 10 .

Ostrea fundata, (Say,) Ravenel, Cat. Coll. Shells, p. 8.

Ostrea fundata, L. R. Gibbes, Tuomey's Geol. So. Ca., appendix, p. xxii.

Description. Shell parasitic, irregular, sub-orbicular, sometimes angular; surface 
squamose, spreading laterally; hinge triangular; beaks sub-acute; lateral margins within raised, crenulated; crenulations extending from the apex, a shorter distance on the anterior side than on the posterior; basal margin smooth; muscular impression large.

Ostrea fundata as quoted above, by Dr. Ravenel and Professor Gibbes, is attributed to Say-but I have not been able yet to find, amongst Mr. Say's writings, any description of this species. In courtesy, the specific name is retained. It is a common shell, adhering to drift wood, shells, etc., in the bays of the Southern coast.

Plate II. Fig. 10, Interior of valve, natural size. The apex has been broken off, which gives the beak in our figure a truncated appearance.

Locality. Simmons'.

Museum, College of Charleston; Cabinet F. S. H.

\section{PECTEN D I L O C A T US.}

Plate II. Fig. 12.

Pecten dislocatus, Say, Jour. Acad. Nat. Sci., Vol. 2, p. 260.

Pecten dislocatus, Say, Amn. Conch., pl. 56, fig. 2.

Pecten dislocatus, Ency. Meth., pl. 213, fig 3.

Pecten dislocatus, Conrad, Amn. Mar. Conch., p. 10, pl. 2, fig. 2.

Pecten purpuratus, Lam., An. sans Vert., Vol. 7, p. 134.

Pecten purpuratus, De Kay, Zool. New-York, Art. Mollusca, p. 174.

Pecten purpuratus, Ravenel, Cat. Coll. Shells, p. 8.

Pecten purpuratus, L. R. Gibbes, Tuomey's Geol. So. Ca., appendix, p. xxii.

Description. Shell sub-orbicular, equilateral; the lower, or left valve, convex; the upper, or right, more compressed, or flat; right auricle of right valve coarsely ribbed; ribs twenty to twenty-two, concentrically and finely wrinkled, and without longitudinal striæ.

The figure in Plate II represents the right valve of this fossil, which differs from the recent species, in being more compressed, and cylindrical; it is undoubtedly identical with the one now in existence upon the coast; the reddish, and almost obsolete spots so characteristic of this shell, is retained in nearly all the fossil specimens, but the color of the shell has been, in every instance, changed to a purpleish lead.

Plate II. Fig. 12, Right valve, natural size.

Locality. Simmons, and sub-marine beds on the Coast.

Museum, College of Charleston; Cabinet F. S. H. 
Genus, LIMA.-Brug.

\section{I I A G L A C I A L I S.- (Not figured)}

Lima glacialis, Lamark, An. sans Vert., 2d Ed., Vol. 7, p. 116.

Lima glacialis, Ravenel, Cat. Coll. Shells, p. 8.

A fragment supposed to be this species has been found in the Post-Pleiocene, but it is not figured in our plate. It lives in deep soundings off the Coast.

Cabinet F. S. H.

\section{P LICA T U LA CRISTATA. \\ Plate II. Fig. 13.}

Plicatula cristata, Lam., An. sans Vert., 2d Ed., Vol. 7, p. 177.

Plicatula cristata, L. R. Gibbes, Tuomey's Geol. So. Ca., appendix, p. xxii.

Plicatula cristata, Ravenel, Cat. Coll. Shells, p. 8.

Plicatula ramosa, Lam., An. sans Vert., 2d Ed., Vol. 7, p. 176.

Plicatula ramosa, De Kay, Zool. New-York, Art. Mollusca, p. 174.

Description. Shell thick and solid, oblong, wedge-shaped, sometimes triangular or irregular; subcristated; having large folds or ribs, which are somewhat scaly; two large prominent teeth in each valve, sometimes curved; ligamental pit between the teeth, deep color, white, with ferruginous spots.

This fossil presents characteristics common to both species of Lamark, as above named; we hesitated for some time to which it belonged, but upon close examination, I find it is more nearly allied to P. CRISTATA; both are found, according to Lamark, in the American seas; P. RAMOSA we are inclined to consider a nominal species.

Plate II. FIG. 13, Exterior of lower valve, natural size, showing point of attachment.

Museum, College of Charleston; Cabinet F. S. H. 
Genus, AVICULA.-Brug.

A VICULA A T L $A$ NTICA.

Plate III. Fig. 1.

Avicula atlantica, Lam., An. sans Vert., 2d Ed., Vol. 7, p. 99.

Avicula atlantica, De Kay, Zool. New-York, Art. Mollusca, p. 175.

Avicula atlantica, L. R. Gibbes, Tuomey's Geol. So. Ca., appendix, p. xxii.

Avicula hirudo, Say, Jour. Acad. Nat. Sci., Phil., Vol. 2, p. 262.

Avicula hirudo, Say, Conch. United States, (Binney,) p. 90.

Description. Shell inequivalve, inequilateral, pearly; obliquely rounded, and striated; concentric lines of growth wrinkled.

This is a rare fossil in the Post-Pleiocene, though quite common on the sea coast of South-Carolina, and often taken alive; the auricles of the fossil are much shorter than in the recent shell, but the descriptions correspond.

Plate III. Fig. 1, Fossil, natural size.

Locality. Abbapoola, and Doctor's Swamp, John's Island.

Museum, College of Charleston; Cabinet F. S.H.

Genus, PINNA.-Linn.

P I N N A S E I N U D A.

Plate III. Fig. 2.

Pinna seminuda, Lam., An. sans Vert., Vol 7, p. 61.

Pinna seminuda, De Kay, Zool. New-York, Art. Mollusca, p. $18 \%$.

Pinna seminuda, Ravenel, Cat. Coll. Shells, p. 7.

Pinna seminuda, L. R. Gibbes, Tuomey's Geol. So. Ca., appendix, p. xxii.

Description. Shell thin; surface longitudinally furrowed; furrows wide, gradually contracting towards the beaks; ridges between the furrows, six to eight, armed with large erect scales on the buccal side of the valves, and extending obliquely to the middle of the 
shell; the rest of the shell is naked, or without spines. It is living on the sea coast of this State.

Plate III. Fig. 2, A fragment, with restored outline.

Locality. Simmons'; Abbapoola.

Museum, College of Charleston; Cabinet F. S. H.

\section{PIN NA MURICA TA.}

Plate III. Fig. 3.

Pinna muricata, Linn, Syst. Nat., p. 1160.

Pinna muricata, Gmel., p. 3364, No. 4.

Pinna muricata, Lamk., An. sans Vert., Vol. 7, p. 64.

Pinna muricata, De Kay, Zool. New-York, Art. Mollusca, p. 187.

Pinna muricata, Ravenel, Cat. Coll. Shells, p. 7.

Pinna muricata, L. R. Gibbes, Tuomey's Geol. So. Ca., appendix, p. xxii.

Description. Shell large, fragile, pellucid, sub-truncated; the dorsal half covered with numerous small, erect, sub-acute scales, arranged in longitudinal furrows; those on the inferior half are much smaller; towards the umbones they become obsolete with age.

As this is a delicate shell, we have obtained only fragments, but they are numerous, and very characteristic of the species. Like its congener, P. SEMINUDA, it lives upon the sea coast, and was abundant in the Post-Pleiocene period.

Plate III. Frg. 3, Fragment, with restored outline.

Locality. Simmons'; Abbapoola.

Museum, College of Charleston; Cabinet F. S. H.

PECTU C C L US CAROLI N E N I S.-(New Species.)

Plate III. Fig. 4.

Description. Shell sub-orbicular, equilateral, radiately ribbed; ribs twenty-three to twenty-five, striate, depressed, disappearing on the buccal and anal margins; concentric lines few, wide apart; teeth seven to ten, robust; beaks prominent. 
This shell is very nearly allied to P. passus, Con., of the Plẹiocene, but may readily be distinguished by its wider and less numerous ribs, which are obsolete on both buccal and anal margins, and by the beaks, which are much more prominent.

We are not aware of its existence in a recent state.

Plate III. Frg. 4, Shell, natural size.

Locality. Simmons'. Museum, College of Charleston; Cabinet F. S. H.

\author{
PECT U N C L US CHARLESTONE N I S-(New Species.) \\ Plate III. Fig. 5.
}

Description. Shell small, somewhat oval, equilateral; buccal and anal sides slightly truncated; ribs numerous, round and elevated; furrows narrow; teeth small, numerous; lips crenate.

This shell has not yet been found living on the Carolina coast, but the small species of the Florida coast seems to be identical with it. It resembles P. aratus, Con., of the Pleiocene; but the ribs are less numerous, and the furrows between them very narrow.

Plate III. Fig. 5, Interior and exterior of shell.

Locality. Calhoun-street, Charleston.

Museum, College of Charleston; Cabinet F. S. H.

\author{
Genus, NUCULA.-LaM. \\ N U C ULA A C UTA. \\ Plate III. Fig. 7.
}

Nucula acuta, Con., Mar. Conch., p. 32, pl. 6, fig. 3.

Nucula acuta, Con., Foss. Ter. Form., p. 57, pl. 30, fig. 2.

Nucula acuta, L. R. Gibbes, Tuomey's Geol. So. Ca., appendix, p. xxi.

Nucula acuta, Tuomey \& Holmes, Pleiocene Fossils So. Ca., p. 53, pl. 17, figs. 10 to 12.

Description. Shell somewhat lanceolate, inequilateral, concentrically striate; buccal 
side short, rounded, inflated; anal side produced, beaked, somewhat recurved; lunule lanceolate.

This little species, which is also an inhabitant of our coast, occurs in the Meiocene of Virginia, and in the Pleiocene and Post-Pleiocene of South-Carolina. It is easily distinguished by its rostrated anal side and regularly striated surface.-T. \& $H$.

Plate III. Fig. 7, Interior of left valve, natural size.

Locality. Stono; Simmons'.

Museum, College of Charleston; Cabinet F. S. H.

N U C ULA P li O X I M A.

Plate III. Fig. 6.

Nucula proxima, Say, Jour. Acad. Nat. Sci., Vol. 2, p. 270.

Nucula proxima, Con., Am. Marine Conch., p. 31, tab. 6, fig. 2.

Nucula proxima, L. R. Gibbes, Tuomey's Geol. So. Ca., appendix, p. xxi.

Nucula proxima, De Kay, Zool. New-York, Art. Mollusca, p. 179.

Nucula proxima, Gould, Invert. Mass., p. 103, fig. 63.

Nucula proxima, Tuomey \& Holmes, Pleiocene Fossils of So. Ca., p. 53, pl. 17, figs. 7 to 9.

Nucula proxima, Say's Conch. United States, (Binney,) p. 90.

Descrirtion. Shell oblique, ovate-triangular, anterior side perpendicular to the base; crossed by minute, concentric, and radiating lines; within pearly; margin crenulated; teeth twelve before and eighteen behind the beaks.-Gould.

The very short buccal side, and pearly interior, are quite characteristic of this shell. It belongs to the actual fauna of the coast, and is found fossil in the Meiocene of Virginia, Pleiocene and Post-Pleiocene of South-Carolina.

Plate III. Fig. 6.

LoCality. Simmons'.

Museum, College of Charleston; Cabinet F. S. H. 
Genus, LEDA,-Schum.

L E D A L I M A T U L A.

Plate III. Fig. 8.

Nucula limatula, Say, Am. Conch., pl. 12.

Nucula limatula, Gould, Invert. Mass., p. 98, fig. 62.

Nucula limatula, Con., Foss. Ter. Form., p. 57, pl. 30, fig. 4.

Nucula limatula, Con., Am. Mar. Conch., pl. 6, fig. 1.

Nucula limatula, De Kay, Zool. New-York, Art. Mollusca, p. 180, pl. 13, fig. 218.

Nucula limatula, Tuomey \& Holmes, Pleiocene Foss. So. Ca., p. 52.

Leda limatula, Stimpson, Shells of New-England, p. 10.

Leda limatula, Say's Conch. United States, (Binney,) p. 164.

Description. Shell elongated, compressed, smooth, polished, inequilateral; buccal side rounded; anal side narrow, somewhat recurved; lunule linear.

Among the fossils of South-Carolina there are no forms of the genus with which this species can be confounded. Its smooth surface, elongated form, and regularly carinated pallial margin, are sufficiently characteristic. Occasionally a few obsolete concentric lines may be seen on the disks, and one or two on the anal margin, towards its extremity.-T. \& $H$.

LEDA Limatula, according to Stimpson and Gould, is now living on the New-England coast. I have never discovered a single living specimen on the Carolina shores, and it is rare as a Post-Pleiocene fossil. In Tuomey \& Holmes' Pleiocene Fossils of Sou th-Carolina, it is said to be abundant on this coast, numerous dead shells having been found upon the beaches, but we fear these were from some sub-marine bed of Post-Pleiocene, and not recent shells. It occurs fossil in the Meiocene of Virginia, and also in the Pleiocene of North and South-Carolina.

Plate III. Fig. 8, Natural size.

Locality. Simmons'; Folly Island Beach.

Museum, College of Charleston; Cabinet F. S. H. 
Genus, ARCA.-Linn.

A R C A I N C O N G R U $\Lambda$.

Plate IV. Figs. 1 and $1 a$.

Arca incongrua, Say, Jour. Acad. Nat. Sci., Vol. 2, p. 268.

Arca incongrua, De Kay, Zool. New-York, Art. Mollusca, p. 178.

Arca incongrua, Ravenel, Cat. Coll. Shells, p. 5.

Arca incongrua, L. R. Gibbes, Tuomey's Geol. So. Ca., appendix, p. xxi.

Arca incongrua, Tuomey \& Holmes, Pleiocene Foss. So. Ca., p. 45, pl. 16, figs. 5 and 6.

Arca incongrua, Say's Conch. U. S., (Binney,) p. 93.

Description. Shell squarely orbicular, inequivalve, radiately ribbed; ribs twenty-six to twenty-eight, buccal side shortest; left valve with crenulated ribs on the buccal and anal margins; right valve has all the ribs crenulated; ligament area wide, lanceolate; umbones approximating.

This is the mostcommon shell on our sea coast, and very numerous in the Post-Pleiocene beds. It is rare in the Pleiocene.

Plate IV. Fig. 1, Valves, natural size.

" 1 a, View of hinge and beaks.

Locality. Charleston; Simmons'.

Museum, College of Charleston; Cabinet F. S. H.

A R C A M ERICANA.

Plate IV. Figs. 2 and $2 a$.

Arca americana, Gray, Reeve, Conch. Icon., pl. 4, fig. 21.

Arca pexata, Ravenel, Cat. Coll. Shells, p. 5.

Arca pexata, L. R. Gibbes, Tuomey's Geol. So. Ca., appendix, p. xxi.

Description. Shell thick, oblong-ovate; buccal margin shortest, and regularly rounded; anal margin obliquely truncated; beaks not ventricose, but prominent, nearly touching, space between them very narrow; ligamental area narrok, and terminating anteriously at 
the beaks; ribs thirty-seven to thirty-nine, radiating, flat, and divided in the middle by a longitudinal line, which becomes obsolete on the umbones; margins strongly impressed within.

This is a common species on the coast of North and South-Carolina, and Georgia; it has been long confounded with Arca PExata, (Say,) a shell limited in its Southern range to Cape Hatteras; A. AMErICANa, is readily distinguished from it by the truncated anal margin; the greater number of ribs, thirty-seven to thirty-nine, and less prominent umbones; the spaces between the ribs are deeper and narrower.

Like A. pexata, (Say,) and A. Holmesir, (Stimpson,) it has the hinge-line terminating at the beaks.

Numerous and fine specimens are obtained from all the Post-Pleiocene beds of the State.

Plate IV. Fig. 2, Exterior, and hinge.

" $2 a$, End view.

Locality. Charleston; Simmons'.

Museum, College of Charleston; Cabinet F. S. H.

\section{$\triangle R$ C A L I E N O S A. \\ Plate IV. Figs. 3 and $3 a$.}

Arca lienosa, Say, Am. Conch., pl. 36.

Arca lienosa, Tuomey \& Holmes, Pleiocene Foss. So. Ca., p. 40, pl. 15, fig. 2.

Arca lienosa, Say's Conch. U. S., (Binney,) p. 192.

Descriptron. Shell equilateral, transversely oblong, inflated, ribbed, rugose; buccal side produced, angular; anal side elongated, obliquely truncated; ribs about thirty-five, unequal, channelled; ligament area, wide, sulcate; sulci slightly diverging, but somewhat parallel to the hinge; umbones distant.

We are not aware of this species now existing, except upon the coast of Florida; it is rare in the Post-Pleiocene, but more abundant in the Pleiocene of South-Carolina.

Plate IV. Fig. 3, Shell, natural size.

" $3 a$, View of hinge.

Locality. Simmons'.

Museum, College of Charleston; Cabinet F. S. H. 
$A R C A$ P O N D ROSA.

Plate IV. Figs. 4 and $4 a$.

Arca ponderosa, Say, Jour. Acad. Nat. Sci., Vol. 2, p. 267.

Arca ponderosa, De Kay, Zool. New-York, Art. Mollusca, p. 177.

Arca ponderosa, Ravenel, Cat. Coll. Shells, p. 5.

Arca ponderosa, L. R. Gibbes, Tuomey's Geol. So. Ca., appendix, p. xxi.

Arca ponderosa, Say's Conch. U. S., (Binney,) p. 92.

Descriptron. Shell thick, ponderous, obliquely-oblong, with thirty to thirty-five ribs; those on the posterior half, impressed with a line or groove; anterior ribs without lines; interstitial spaces equal to width of ribs; buccal margin thick, rounded; anal margin angularly produced, obliquely truncated, thin; pallial margin contracted in the middle; ligamental area wide, crossed with prominent lines or ridges, corresponding to the teeth; umbones prominent, remote.

A. Ponderosa is a Southern coast shell, and very abundant in the Post-Pleiocene.

Plate IV. Fig. 4, Shell, natural size.

" $4 a$, Hinge view.

Locality. Charleston; Simmons'.

Museum, College of Charleston; Cabinet F. S. H.

\section{A R C A T R A N S V E R A.}

Plate IV. Figs. 5 and $5 a$.

Arca transversa, Say, Jour. Acad. Nat. Sci., Vol. 2, p. 269.

Arca transversa, Con., Foss. Shells Ter. Form., No. 2, p. 15, tab. 1, fig. 2.

Arca transversa, Gould, Invert. Mass., p. 96.

Arca transversa, Ravenel, Cat. Coll. Shells, p. 5.

Arca transversa, L. R. Gibbes, Tuomey's Geol. So. Ca., appendix, p. xxi.

Arca transversa, Tuomey \& Holmes, Pleiocene Foss. So. Ca., p. 42, pl. 15, figs 6 and 7.

Arca transversa, Stimpson, Shells New-England, p. 8.

Arca transversa, Say's Conch. U. S., (Binney,) p. 93.

Description. Shell transversely oblong, sub-rhomboidal; buccal side shorter, regularly rounded, angular above; anal side elongated, angular; ligamental area narrow, furrowed; 
ribs about thirty-five, nodulous in the right valve of young shells; in the left, only those on buccal side are thus ornamented.

A. transversa is now living on the coast, and is found fossil in the Meiocene of Virginia, Pleiocene and Post-Pleiocene of South-Carolina.

Plate IV. Fig. 5, Shell, natural size.

" 5 a, hinge vien.

Locality. Simmons'; Doctor's Swamp, John's Island; Hamblin's, Christ Church.

Museum, College of Charleston; Cabinet F. S. H.

\author{
A R C C EL A T A. \\ Plate IV. Figs. 6 and $6 a$.
}

Arca cælata, Con., Foss. Ter. Form., p. 61, pl. 32, fig. 2.

Arca cælata, Tuomey \& Holmes, Pleiocene Foss. So. Ca., p. 36, pl. 16, figs. 8 to 10.

Description. Shell trapezoidal; disk widely and not profoundly contracted; ribs numerous, alternated towards the base, tuberculated, aculeated anteriorly and posteriorly ; posterior slope depressed; umbo acutely angulated behind; basal margin slightly arched; posterior margin obliquely truncated; beaks approximate.-Con.

This species is rare in the recent state on the coast of South-Carolina, but is a common fossil in the Post-Pleiocene beds.

It is a beautiful little shell, much ornamented by its nodulous radiating striæ.

Plate IV. FIG. 6, Shell, natural size.

" $6 a$, Hinge view.

Locality. Abbapoola Creek, John's Island.

Museum, College of Charleston; Cabinet F. S. H. 
Genus, CHAMA.-LinN.

C H A M A A R C I N E L L A.

Plate V. Fig. 1.

Chama arcinella, Linn, Syst. Nat., p. 1139.

Chama arcinella, L. R. Gibbes, Tuomey's Geol. So. Ca., appendix, p. xxii.

Chama arcinella, Ravenel, Cat. Coll. Shells, p. 7.

Chama arcinella, Tuomey \& Holmes, Pleiocene Foss. So. Ca., p. 22, pl. 7, figs. 4, $5,6$.

Description. Shell orbicular-cordate ; ribs radiating, spinous; spines strong, recurved tubular; interstices deep, punctate in young specimens; lunule broadly cordate, buccal side granulated.- $T$. \& $H$.

A few specimens of very young shells, not spinous, but granulated, and with very indistinct characters, have been taken from the Post-Pleiocene sands of South-Carolina. It is rare in the living state upon the coast, but common on the Florida shores. The Pleiocene specimens are very large, with prominent spines.

Plate V. Fig. 1, Natural size.

Locality. Simmons'; Wadmalaw Sound.

Museum, College of Charleston; Cabinet F. S. H.

$$
\begin{gathered}
\text { CARDIA D E. } \\
\text { Genus, CARD I M . - Lin . } \\
\text { C A R D I M I A G N M. } \\
\text { Plate V. Figs. } 2 \text { and } 2 a .
\end{gathered}
$$

Cardium magnum, Born., Test. Mus. Cœs. Vind, pl. 3, fig. 5.

Cardium magnum, Tuomey \& Holmes, Pleiocene Foss. So. Ca., p. 63, pl. 19, fig. 1.

Cardium maculatum, Gmelin, Conch. Icon., pl. 4, fig. 20.

Cardium maculatum, Ravenel, Cat. Coll. Shells, p. 5.

Cardium ventricosum, Bruguiere, Lam., An. sans Vert., Vol. 6, p. 400.

Cardium ventricosum, De Kay, Zool. New-York, Art. Mollusca, p. 207.

Cardium ventricosum, L. R. Gibbes, Tuomey's Geol. So. Ca., appendix, p. xxi.

Description. Shell very large, inflated, obliquely cordate; anal side somewhat angularly depressed; radiately ribbed; ribs flattened, buccal ribs crenulated. 
This shell presents some variation in form; some individuals are more ventricose, whilst others present a greater disproportion between the length and height. In young specimens, the crenulations on the ribs, on the buccal side, are not always prominent, but after they attain to the height of an inch or two they appear and are very persistent. The buccal ribs are somewhat angular, with the angles turned towards the anal side.-T. \& $H$.

Cardium Magnum is a common recent shell on the coast; is rare as fossil in the Pleiocene, but abundant in the Post-Pleiocene.

Plate V. Fig. 2, Exterior and interior of valves, natural size.

" $2 a$, Side vien of shell.

Locality. Simmons'.

Museum, College of Charleston; Cabinet F. S. H.

\section{CARDIUM MURICATUM.-LINA.}

Plate V. Fig. 3.

Cardium muricatum, Linn, Syst. Nat., p. 1123.

Cardium muricatum, Lam., Vol. 6, p. 398.

Cardium muricatum, Conch. Icon., pl. 6, fig. 33.

Cardium muricatum, Chemn., 6, pl. 17, fig. 177.

Cardium muricatum, Ency. Meth., pl. 297, fig. 1.

- Cardium muricatum, Lister, Conch., pl. 322, fig. 159.

Cardium muricatum, Ravenel, Cat. Coll. Shells, p. 5.

Cardium muricatum, De Kay, Zool. New-York, Art. Mollusca, p. 207.

Cardium muricatum, L. R. Gibbes, Tuomey's Geol. of So. Ca., appendix, p. xxi.

Cardium muricatum, Tuomey \& Holmes, Pleiocene Foss. So. Ca., p. 64.

Description. Shell large, cordately ovate, somewhat oblique, radiately ribbed; ribs convex, muricated with minute, compressed, obliquely arranged tubercles. On the buccal side of the shell, the tubercles are on the anterior side of the ribs; these are followed by a few ribs which are muricated on both sides; and on the anal side the tubercles are turned backwards.-T. \& $H$.

Living on the coast of South-Carolina and rarely found fossil in the Pleiocene or PostPleiocene formations.

Plate V. Fig. 3, Exterior of valve, natural size.

Locality. Simmons'.

Museum, College of Charleston; Cabinet F. S. H. 
CARDIUH ISOCARDIA.

Plate V. Fig. 4.

Cardium isocardia, Linn., Syst. Nat., p. 1122.

Cardium isocardia, Chemn., 6, p. 182.

Cardium isocardia, Wood, Conch., p. 217.

Cardium isocardia, Lam., An. sans Vert., p. 398.

Cardium isocardia, Wood, Index Testaceologicus, pl. 5, fig. 15.

Cardium isocardia, Ravenel, Cat. Coll. Shells, p. 5.

Cardium isocardia, L. R. Gibbes, Tuomey's Geol. So. Ca., appendix, p. xxi.

Cardium isocardia, Adams, Gen. Recent Shells, Vol. 2, p. 455.

Description. Shell obliquely cordate, inequilateral, ventricose, imbricated; anal margin coarsely serrated or notched; ribs thirty to thirty-five, imbricated, sub-fornicated.

Like Cardiun serRatum, this shell, when compared with living specimens, presents characters very much modified by the influences of the conditions of the age in which it lived. I find dead and water-worn shells, on our sea beaches, which to our mind are undoubtedly Post-Pleiocene fossils; the animal does not exist on the Carolina coast, but inhabits the West India seas and Gulf of Mexico.

What is considered a curious incident may be here alluded to; of twenty-six or eight specimens found, there is not a single right-hand valve.

Plate V. Fig. 5, Exterior of valve, natural size.

Locality. Abbapoola; Folly Island; and Simmons'.

Museum, College of Charleston; Cabinet F. S. H.

Genus, L $\mathbb{E}$ VICARDIUM.-SWAIN SON.

L $\mathbb{E}$ VICAR DIUM SERRATU M.

Plate V. Fig. 5.

Cardium serratum, Linn., Syst. Nat., p. 1123.

Cardium serratum, Chemn., 6, pl. 18, fig. 189.

Cardium lævigatum, Lamk., An. sans Vert., Vol. 6, p. 403.

Lævicardium serratum, Adams, Gen. Recent Shells, Vol. 2, p. 457.

Descriptions. Shell thin, smooth, obliquely ovate, inequilateral, ventricose, with 
numerous somewhat obsolete radiating lines, which extend to basal margin; the buccal and anal sides are smooth, and without lines; buccal margin round, curve continuous to base of anal margin; anal margin obliquely truncated; interior of the shell profoundly crenulated on the pallial margin only; serratures towards the anterior end large and prominent; the buccal and anal margins are without crenulations, and have thin edges.

This shell resembles C. sublineatum, Con., of the Pleiocene, but is readily distinguished by being more ventricose, having the anal margin truncated, and the crenulations of the pallial margin more profound. It is also a larger and a longer shell. But one valve has yet been found in the Post-Pleiocene. It is not known to be living upon the coast of South-Carolina, but dead shells (Post-Pleiocene fossils?) are sometimes found on the beaches. For a long time we were doubtful about this shell, it being much larger than C. serratum, of the Florida coasts; but I am now satisfied the size, and other minor differences, are to be attributed to more favorable conditions for greater development which existed during the Post-Pleiocene age.

Plate V. Fig. 5, Exterior, natural size.

LocaltTy. Abbapoola Creek.

Museum, College of Charleston; Cabinet F. S. H.

\section{C $\triangle R$ D I M MORTONI. \\ Plate V. Fig. 6.}

Cardium Mortoni, Con, Jour. Acad. Nat. Sci., Vol. 6, p. 259, pl. 11, figs. 5, 6, 7.

Cardium Mortoni, Gould, Invert. Mass., p. 91.

Cardium Mortoni, De Kay, Zool. New-York, Art. Mollusca, p. 207, pl. 23, fig. 251.

Cardium Mortoni, Stimpson, Shells New-England, p. 19.

Description. Shell small, thin, sub-ovate, oblique, smooth, without ribs or radiating striæ.

According to Conrad, Gould, and Stimpson, this small shell is common on the Northern Atlantic coast of the United States. I have not yet found it on the Carolina coast, and it is exceedingly rare in the Post-Pleiocene.

Plate V. Fig. 6, Shell, natural size. This figure was accidentally blurred in the printing.

Locality. Simmons'. Museum, College of Charleston; Cabinet F. S. H. 
Genus, LUCINA.-Brug.

\section{U C INA DIVARICATA.}

Plate VI, Fig. 1.

Tellina divaricata, Linn., Syst. Nat., 1120.

Lucina divaricata, Lam., An. sans Vert., Vol. 4, p. 541.

Lucina divaricata, Con., Foss. Ter. For., p. 39, pl. 20, fig. 3.

Lucina divaricata, Ravenel, Cat. Coll. Shells, p. 4.

Lucina divaricata, Gould, Invert. Mass., p. 70.

Lucina divaricata, L. R. Gibbes, Tuomey's Geol. So. Ca., appendix, p. xxi.

Lucina divaricata, Tuomey \& Holmes, Pleiocene Foss. So. Ca., p. 59, pl. 18, figs. 10 and 12. Lucina strigilla, Stimpson, Shells New-England, p. 17.

Strigilla divaricata, Turton, Test. Brit., p. 119.

Description. Shell orbicular, somewhat globose, thin, groove-striated in two directions; striæ divaricate. This pretty species is easily distinguished from its congeners, by the regular outline and sharply cut divaricating striæ.

It is difficult to believe a species to have so wide a distribution, both horizontally and vertically, as this is said to have. It occurs in the Eocene of Europe, in the Meiocene of Virginia, in South-Carolina in both Pleiocene and Post-Pleiocene, and belongs to the living fauna of our entire coast.-T.\& $H$.

It is very possible that several species are included under this specific name.

Plate VI. Fig. 1, Exterior of left valve.

Locality. Simmons'.

Museum, College of Charleston.

\section{U CINA COSTATA.}

Plate VI. Fig. 2.

Lucina costata, Tuomey \& Holmes, Pleiocene Foss. So. Ca., p. 60, pl. 18, figs. 12 and 13.

Descriftion. Shell orbicular, thick, compressed, radiately ribbed, concentrically striate, and towards the pallial margin somewhat sulcate.

This fossil is readily distinguished from the small Lucinide which it resembles, by the prominent rounded ribs. 
It occurs in great abundance in the Post-Pleiocene beds near Charleston, although it has not as yet been found amongst the living fauna of the State.-T. \& $H$.

Plate VI. Fig. 2, Shell, natural size.

Locality. Abbapoola Creek. Museum, College of Charleston; Cabinet F. S. H.

\section{UCINA RADIANS. \\ Plate VI. Fig. 3.}

Lucina radians, Con., Am. Jour. Sci. and Arts, Vol. 41, p. 347.

Lucina radians, Con., Foss. Shells Ter. For., p. 70, pl. 40, fig. 3.

Lucina radians, Tuomey \& Holmes, Ploiocene Foss. So. Ca., p. 57, pl. 18, fig. 4 and 5.

Description. Shell orbicular, concentrically and regularly striate; radiately and obsoletely striate; lunule excavated.

The beaks are prominent and acute, the concentric lines are close and well-defined, the radiating lines somewhat irregular, and on the anal side more distant and prominent. L. multilineata resembles the young of this species, but the radiating lines are more regular and the shell more convex than in the species under consideration.

This pretty species is found on the coast of North and South-Carolina, and in the PostPleiocene. It is readily distinguished by its prominent umbones, close and regular concentric striæ and obsolete rather irregular radiating lines.-T. \& $H$.

Plate VI. Fig. 3, Shell, natural size.

Locality. Simmons'. Museum, College of Charleston; Cabinet F. S. H.

\section{LUCINA TRISULCATA.}

Plate VI. Fig. 4.

Lucina trisulcata, Con., Foss. Ter. For., p. 71, pl. 40, fig. 5.

Lucina trisulcata, Tuomey \& Holmes, Pleiocene Foss. So. Ca., pl. 18, figs. 18 and 19.

Description. Shell ovate, convex, inequilateral ; concentrically striate and channelled; lunule cordate, deeply excavated. 
This fossil resembles L. CRENUlata; but it is readily distinguished from that species by its less orbicular outline, its prominent and more oblique beaks, and above all, by the short but very deep lunule, which extends under the beaks. The concentric sulci which suggested the specific name to Mr. Conrad, are accidental, quite variable in number and position, and in the larger number of individuals they are absent altogether: The short and deep lunule will serve to characterise all the varieties of the species. $-T$. \& $H$.

Plate VI. Fig. 4, Natural size.

Locality. Simmons'.

Museum, College of Charleston; Cabinet F. S. H.

L U C I A KI A W A H N S S. - (New Species.)

Plate VI. Fig. 5.

Description. Shell sub-orbicular, equilateral, truncately rounded anteriorly and posteriorly, convex, diaphanous, concentrically and finely striated, not punctate; striæ numerous, indistinct, irregular; beaks prominent, but not acute; internal margin entire.

This shell very nearly resembles L. punctulata, (Lea, $)$ of the Meiocene of Virginia, but differs from that species in being not punctulated, but concentrically, numerously and finely striated; it also differs in being of much greater size, often five times as large.

It is very abundant in the Post-Pleiocene, but unknown in a living state.

I have given to this shell the Indian name of Ashley River, which is Kiawah; it was upon its banks we first discovered it.

Plate VI. Fig. 5, Natural size.

Museum, College of Charleston; Cabinet F. S.H.

LUCINA. MULTILINEATA.

Plate VI. Fig. 6.

Lucina multilineata, Con., Foss. Ter. For., p. 71, pl. 40, fig. 6.

Lucina multilineata, Tuomey \& Holmes, Pleiocene Foss. So. Ca., p. 61, pl. 18, figs. 16 and 17.

Description. Shell orbicular, concentrically and closely ribbed, radiately striate.

This little fossil has the outline and general characters of L. CREnulata, from which 
it can only be distinguished by the radiating lines which give the shell a cancellated appearance.

It occurs in the Post-Pleiocene, and is often confounded with L. CREnUlata.

Plate VI. Fig. 6, Natural size.

Locality. Simmons', Wadmalaw Sound.

Museum, College of Charleston; Cabinet F. S. H.

\title{
L U C I A CRENULATA.-(Not figured.)
}

Lucina crenulata, Con., Foss. Ter. For., p. 39, pl. 20, fig. 2.

Lucina crenulata, Tuomey \& Holmes, Pleiocene Foss. So. Ca., p. 60, pl. 18, figs. 14 and 15.

Description. Shell orbicular, inflated, concentrically lamellated; lunule slightly excavated.

This little species is readily distinguished by its orbicular outline and the closely arranged concentric lamellæ; the lunule is short and deep. It is distinguished from $\mathrm{L}$. MULTilineata, which it resembles, by the absence of radiating lines. It is quite common in the Meiocene of Virginia, and is living along the coast from the Chesapeake to Florida.-T. \& $H$.

Locality. Abbapoola.

Museum, College of Charleston; Cabinet F. S. H.

\author{
Genus, MONTACUTA.-Turt. \\ M O T $А$ C UTA BO W M A I.-(New Species.) \\ Plate VII. Fig. 2.
}

Description. Shell small, fragile, ovate-triangular, inequilateral, slightly compressed, concentrically and finely striated in bands of yellow and white; beaks very small, acute; buccal and anal margins regularly rounded; tooth on the buccal side excavated; two teeth in each valve; cavity between them for the ligament.

This little shell corresponds somewhat with Gould's description of Montacuta BIdentata, which is living on the coast of Massachusetts, but differs in size and general outline; and, what is most characteristic, the alternate opake and translucent concentric bands on the surface. It does not exist on the coast of South-Carolina. 
I take pleasure in dedicating this pretty species to a highly valued friend, Major A. H. Bowman, whose scientific attainments command for him the highest estimation of his government, and the admiration of a large circle of friends in South-Carolina.

Plate VII. Fig. 2, Natural size, and magnified hinge.

Museum, College of Charleston; Cabinet F. S. H.

\section{CYRENA CAROLINIENSIS.}

Plate Vi. Fig. 7.

Cyclas Caroliniensis, Bosc., Hist. Nat. des Coq. 2, pl. 18, fig. 4.

Cyrena Caroliniensis, Lamk., An. sans Vert., Vol. 6, p. 276.

Cyrena Caroliniensis, Ravenel, Cat. Coll. Shells, p. 4.

Cyrena Caroliniensis, L. R. Gibbes, Tuomey's Geol. So. Ca., appendix, p. xxi.

Description. Shell sub-cordate, thick, sub-inequilateral, tumid; beaks distant, eroded.

Only a single valve, much water-worn, and quite small, has been yet found in the Post-Pleiocene; it is abundant in the brackish water of the rush lands of the Carolina sea-coast.

Plate VI. Fig. 7.

Locality. Simmons'; Doctor's Swamp, John's Island.

Cabinet F. S. $H$.

Genus, CARDita.-Brug.

CARDITA TRIDENTATA.

Plate VI. Fig, 8.

Venericardia tridentata, Say, Jour. Acad. Nat. Sci., Vol. 5, p. 216.

Cardita tridentata, Con., Foss. Ter. For., p. 76, pl. 43, fig. 11.

Cardita tridentata, Tuomey \& Holmes, Pleiocene Foss. So. Ca., p. 67, pl. 19, figs. 8 and 9.

Cardita tridentata, Say's Conchology U. S., (Binney,) p. 194.

Description. Shell round, triangular, thick, radiately ribbed; ribs elevated, strongly crenulated. 
This little species is distinguished by its sub-triangular outline, thick, robust and coarsely crenulated ribs. The beaks are slightly turned forward. There are two teeth in the left, and one in the right valve. The species is an inhabitant of the southern coast, and common in the Post-Pleiocene of South-Carolina; we have never found larger specimens.

Plate VI. Fig. 8, Natural size.

Locality. Simmons'; Wadmalaw.

Museum, College of Charleston; Cabinet F. S. H.

\author{
CARDITA FLORIDANA. \\ Plate VII. Fig. 1.
}

Cypricardia Floridana, Con., Foss. Ter. Form. U. S., p. 12. Observations on C. arata.

Description. Shell ovately oblong; ribs fifteen, transversely radiated, rounded, nodulous; buccal side very short; anal truncated.

This shell is living on the Florida coast, but has not yet been discovered on that of Carolina, and only a single valve found in the Post-Pleiocene.

I give an outline of natural size, and a magnified figure.

Plate VII. Fig. 1.

Locality. Simmons'.

Cabinet F. S. H.

\title{
ASTARTE I U N ULATA. \\ Plate VI. Fig. 9.
}

Astarte lunulata, Con., Foss. Ter. Form., p. 44, pl. 21, fig. 8.

Astarte lunulata, L. R. Gibbes, Tuomey's Geol. So. Ca., appendix, p. xxi.

Astarte lunulata, Tuomey \& Holmes, Pleiocene Foss. So. Ca., p. 72, pl. 20, fig. 4.

Astarte mactracea, Stimpson, Shells New-England, p. 18.

Description. Shell small, flat, somewhat angular, concentrically furrowed; buccal margin truncated; anal margin somewhat angular. 
This little species is at once known by the regular and angular furrows; straight sides, and prominently arched pallial margin, which is smooth within.

It occurs living on the coast of New-England, South-Carolina, and in the Gulf of Mexico.

Plate VI. Fig. 9, Natural size.

Locality. Simmons'.

Museum, College of Charleston; Cabinet F. S. II.

\section{Genus, MERcENARIA.-Schumacher.}

MERCENARIA VIOLACEA.

Plate VI. Fig. 11.

Venus mercenaria, Linn., Syst. Nat., 1131.

Venus mercenaria, Gmelin, 3231.

Venus mercenaria, Lam., An. sans Vert., Vol. 6, p. 346.

Venus mercenaria, Dill, Cat., Vol. 1, p. 176.

Venus mercenaria, Wood, Index, pl. 7, fig. 40.

Venus mercenaria, Gould, Invert. Mass., p. 85, fig. 67.

Venus mercenaria, De Kay, Zool. New-York, Art. Mollusca, p. 217, pl. 27, fig. 276.

Venus mercenaria, Ravenel, Cat. Coll. Shells, p. 4.

Venus mercenaria, L. R. Gibbes, Tuomey's Geol. So. Ca., appendix, p. xxi.

Venus mercenaria, Stimpson, Shells New-England, p. 19.

Venus mercenaria, Tuomey \& Holmes, Pleiocene Foss. So. Ca., p. 81, pl. 21, fig. 6.

Mercenaria violacea, Adams, Gen. Recent Shells, Vol. 2, p. 419.

Description. Shell solid, obliquely cordate, concentrically furrowed, radiately striate, anal side somewhat produced, angled; buccal side short, rounded; umbones recurved; lunule heart shaped.-T.\& $I$.

The anal slope is comparatively straight, and where it joins the pallial margin, it is slightly produced into a flattened lip.

This species attains considerable size, and then resembles Mercenaria mortoni, (Con.) It is the common clam of the coast; it existed in South-Corolina during the Pleiocene and Post-Pleiocene periods.

Plate VI. Fig. 11, Right valve, natural size.

" 11 a, Lunule, natural size. 


\section{MERCENARIA MORTONI.}

Plate VI. Fig. 12.

Venus Mortoni, Conrad, Jour. Acad. Nat. Sci., Vol. 7, p. 251.

Venus Mortoni, Conrad, Foss. Ter. Form., p. 8, pl. 5, fig. 1.

Venus Mortoni, De Kay, Zool. New-York, Art. Mollusca, p. 219.

Mercenaria Mortoni, Adams, Gen. Recent Shells, Vol. 2, p. 419.

Descriftion: Shell cordate, inflated, thick and ponderous, with prominent recurved concentric laminæ, more elevated on the anterior and posterior margins; ligament margin arctuate; umbones prominent; lunule large, cordate, defined by a deep groove; posterior extremity slightly emarginate; inner margin regularly crenulated.-Conrad.

This is the most abundant species of the genus found in the Post-Pleiocene beds, and though not common in the recent state, is still living upon the coast. Mr. Conrad founded the species upon a specimen from Charleston harbor.

Plate VI. Fig. 12, Right valve, natural size.

" $12 a$, Lunule, natural size.

Locality. Simmons'.

Museum, College of Charleston; Cabinet F. S. H.

MERCENARIA NOTATA.

Plate VI. Fig. 13.

Venus notata, Say, Jour. Acad. Nat. Sci., Vol. 2, p. 271.

Venus notata, Gould, Invert. Mass., p. 86, fig. 52.

Venus notata, De Kay, Zool. New-York, Art. Mollusca, p. 218, pl. 27, fig. 278.

Venus notata, Ravenel, Cat. Coll. Shells, p. 5.

Venus notata, L. R. Gibbes, Tuomey's Geol. So. Ca., appendix, p. xxi.

Mercenaria notata, Adams, Gen. Recent Shells, Vol. 2, p. 419.

Venus notata, Say's Conch. U. S., (Binney,) p. 49.

DESCRIPTION. Shell sub-cordate, obtusely rounded before, sub-angulated posteriorly; lateral dorsal margin nearly straight, concentric laminæ, more elevated on the posterior and anterior margins, and crossed by radiating striæ, which give the shell a sub-cancellated character; pallial margin beautifully crenulated; color, whitish, with brown and reddish zig-zig marks; interior margin white, cavity of shell bright purple. 
This beautiful little shell was rare in the Post-Pleiocene period, and though living on the coast of South-Carolina, is not abundant.

Plate VI. Fig. 13, Right valve, natural size.

Locality. Simmons'.

Cabinet F. S. H.

Genus, Chione-Megerle Von Muhlfeldt.

CHIONE CA NCELLATA.

Plate VI. Fig. 14.

Venus cancellata, Linn., Syst. Nat., 12th Ed., p. 1130.

Venus cancellata, Tuomey \& Holmes, Pleiocene Foss. So. Ca., p. 84, pl. 21, fig. 11.

Chione cancellata, Adams, Gen. Recent Shells, Vol. 2, p. 421.

Description. Shell thick, somewhat compressed, decussated, radiately striate, concentrically sulcate; furrows remote, unequal, elevated; anal side lamellar, cardinal teeth thick, lunule cordate, buccal margin regularly rounded, anal margin sub-angulated; pallial margin crenulated.

This shell is easily distinguished by the raised, concentric and remote lines of growth, the radiating striæ are alternately larger and smaller. It is an abundant species in the Post-Pleiocene; and from the number of dead shells found upon our sea-beaches, we infer it is living on the coast.

Plate VI. Fig. 14, Natural size.

Locality. Simmons'.

Museum, College of Charleston; Cabinet F. S. H.

\section{CHIONE C RIBRARIA.}

Plate VI. Fig. 15

Venus cribraria, Con., Pro. Acad. Nat. Sci., Vol. 1, p. 310.

Venus cribraria, Con., Foss. Ter. Form., p. 67, pl. 38, fig. 2.

Venus cribraria, Tuomey \& Holmes, Pleiocene Foss. So. Ca., p. 83, pl. 21, fig. 10.

Description. Shell sub-trigonal, slightly ventricose; ribs twenty-five to thirty, con- 
centric, lamelliform, elevated, recurved, with elevated transverse striæ on the inferior side of each; lunule cordate, laminated, crenulated on the buccal and pallial margins within, crenulations extending from beak to base of anal margin; teeth divaricate, unequal, triangular.

This shell is sometimes found living on the coast, but very rare in the Post-Pleiocene.

Plate VI. Fig. 15, Natural size.

Locality. Artesian Well, Charleston; Simmons'; Abbapoola.

Museum, College of Charleston; Cabinet F. S. H.

Genus, CALLISTA.-PoLi.

C A L L IS TA. GI G A N T EA.

Plate Vil. Fig. 3.

Venus gigantea, Gmel., p. 3282.

Venus gigantea, Chemn., 10, p. 254, t. 171, fig. 1661.

Venus gigantea, Dillwyn, Cat., Vol. 1, p. 202.

Cytherea gigantea, Wood, Index, pl. 8, fig. 100.

Cytherea gigantea, Lam., An. sans Vert., 2d Ed., Vol. 6, p. 302.

Callista gigantea, Adams, Gen. Recent Shells, Vol. 2, p. 425.

Description. Shell large, ovate, smooth, podished, very inequilateral; buccal side short, rounded; anal side produced, sub-angulated; lunule ovate, impressed, keeled in the middle. In the recent state, it is prettily coloured with numerous bluish longitudinal rays.

This fine shell is often found in the Post-Pleiocene, and seems to have flourished during that period; it is living on the Carolina coast in deep soundings, but the shells are seldom found on the beaches. It is common on the Florida shores.

Plate VII. Fig. 3, Shell, natural size.

Locality. Simmons'.

Museum, College of Charleston; Cabinet F. S. H. 


\title{
Genus, DOSINIA.-Scopoli.
}

\author{
D O S I N I A O N C E N T R I C A.
}

Plate VII. Fig. 4.

Venus concentrica, Gmel., p. 3286, No. 82.

Venus concentrica, Dillwyn's Catalogue, Vol. 1, p. 196.

Venus concentrica, Tuomey \& Holmes, Pleiocene Foss. So. Ca., p. 82, pl. 21, fig. 7.

Artemis concentrica, Born., Sow. Gen., fig. 4.

Artemis concentrica, Conrad, Amn. Marine Conch., p. 55.

Artemis concentrica, L. R. Gibbes, Tuomey's Geol. So. Ca., appendix, p. xxi.

Cytherea concentrica, Lam., Vol. 6, p. 316.

Dosinia concentrica, Adams, Gen. Recent Shells, Vol. 2, p. 431.

Description. Shell sub-orbicular, depressed, almost equilateral, concentrically striated; striæ equal, closely arranged, distinct; lunule sub-cordate ; ligament sunk ; margins even; muscular impressions large; pallial sinus angular, ascending; dorsal cleft for hinge lanceolate and gaping.

Dosinia concentrica is one of the most common recent shells of the Southern coast, and abundant in the Post-Pleiocene.

Plate VII. Fig. 4, Natural size.

Locality. Simmons'.

Museum, College of Charleston; Cabinet F. S. H.

\section{Genus, TA PES.-M U H F E L T.}

T A PES GRUS.-(New Species.)

Plate VII. Fig. 5 .

Description. Shell small, convex, transversely oblong, sub-rhomboidal, inequilateral, with twenty-five or twenty-six ribs; ribs radiating, and interrupted by distinct overlapping zones of increase, which give the shell a laminated, or squamose appearance; umbones, anterior; dorsal margin thick, rectilinear, or very slightly curved, without ribs, squamose; posterior margin sub-truncated, anterior margin shorter, regularly rounded; pallial margin crenated; pallial sinus deep; muscular impressions large. 
This shell is now living on the coast of South-Carolina.

Plate VII. Fig. 5.

Locality. Simmons'.

Cabinet F. S. H.

Genus, PETRICOLA.-Lam.

PETRICOLA PHOLADIFORMIS.

Plate VII. Fig. 6.

Petricola pholadiformis, Lam., An. sans Vert., 3d Ed., Brux, Vol. 2, p. 554.

Petricola pholadiformis, Sowerby's Genera, pl. Petricola, figs. 1 and 2.

Petricola pholadiformis, Con., Am. Marine Shells, p. 37, pl. 7.

Petricola pholadiformis, Desh., Ency. Meth., p. 747.

Petricola fornicata, Say, Jour. Acad. Nat. Sci., Vol. 2, p. 319.

Petricola pholadiformis, Say, Amn. Conch., pl. 60, fig. 1.

Petricola pholadiformis, Ravenel, Cat. Coll. Shells, p. 3.

Petricola pholadiformis, Gould, Invert. Mass., p. 63.

Petricola pholadiformis, De Kay, Zool. New-York, Art. Mollusca, p. 228, pl. 33, fig. 228.

Petricola pholadiformis, L. R. Gibbes, Tuomey's Geol. So. Ca., appendix, p. xxii.

Petricola pholadiformis, Tuomey \& Holmes, Pleiocene Foss. So. Ca., p. 87.

Petricola pholadiformis, Adams, Gen. Recent Shells, Vol. 2, p. 441.

Petricola pholadiformis, Say's Conch. U. S., (Binney,) p. 222.

Description. Shell elongated, cylindrical, inequilateral; buccal side very short, rounded radiately, and striate; ribs lamellar; anal side produced; lunule ovate.

Common along the whole Atlantic coast of the United States.

Plate VII. Fig. 6. 
PETRICOLA DACTYLUS.

Plate VII. Fig. 7.

Petricola dactylus, Sovv, Gen. Shells, pl. 3.

Petricola dactylus, Say, Amn. Conch., pl. 60, fig. 2.

Petricola dactylus, Gould, Invert. Mass., p. 65, fig. 41.

Petricola dactylus, De Kay, Zool. New-York, Art. Mollusca, p. 228, pl. 28, fig. 283, a, $b$.

Petricola dactylus, Ravenel, Cat. Coll. Shells, p. 3.

Petricola dactylus, L. R. Gibbes, Tuomey's Geol. So. Ca., appendix, p. xxi.

Petricola dactylus, Stimpson, Shells of New-England, p. 24.

Petricola dactylus, Adams, Gen. Recent Shells, Vol. 2, p. 441.

Petricola dactylus, Say's Conch. U. S., (Binney,) p. 222.

Description. Shell elongately-ovate, thick, irregular, inequilateral, covered with radiating lines, and ribs; those on buccal side raised, distinct, without scales; no areola before the beaks.

Common along the whole A tlantic coast of North-America.

Plate VII. Fig. 7 .

Museum, College of Charleston.

\section{Genus, MACTRA.-LINN.}

M A C T R A S I M I L I S.

Plate VII. Fig. 8.

Mactra similis, Say, Jour. Acad. Nat. Sci., Vol. 2, p. 309.

Mactra similis, De Kay, Zool. New-York, Art. Mollusca, p. 230.

Mactra similis, Ravenel, Cat. Coll. Shells, p. 2.

Mactra similis, Stimpson, Shells of New-England, p. 20.

Mactra similis, L. R. Gibbes, Tuomey's Geol. So. Ca., appendix. p. xxii.

Mactra similis, Tuomey \& Holmes, Pleiocene Foss. So. Ca., p. 97, pl. 23, fig. 8.

Mactra similis, Say's Conch U. S., (Binney,) p. 101.

Description. Shell oblong-oval, equilateral, surface finely marked with concentric lines of growth, which are almost obsolete, and always interrupted irregularly with two or 
three raised sub-laminated concentric lines; buccal and anal margins nearly equally rounded, the anal a little more pointed in some specimens; beaks central.

This is a very abundant living species on the Southern coast, and somewhat resembles in outline M. oblongata, but is easily distinguished, as the folds on the buccal end are wanting; it is also a thicker shell than M. oblongata.-T. \& $H$.

Plate VII. Fig. 8, Natural size.

Locality. Simmons'; Abbapoola; St. Andrew's.

Museum, College of Charleston; Cabinet F. S. H.

\section{MA T RA LATERALIS.}

Plate VII. Fig. 9.

Mactra lateralis, Say, Jour. Acad. Nat. Sci., Vol. 2, p. 309.

Mactra lateralis, Con., Amn. Mar. Conch., p. 62, pl. 14, fig. 2.

Mactra lateralis, Gould, Invert. Mass., p. 54, figs. 34, 35.

Mactra lateralis, Ravenel, Cat. Coll. Shells, p. 2.

Mactra lateralis, Stimpson, Shells of New-England, p. 20.

Mactra lateralis, L. R. Gibbes, Tuomey's Geol. So. Ca., appendix, p. xxii.

Mactra lateralis, De Kay, Zool. New-York, Art. Mollusca, p. 230, pl. 29, fig. 287.

Mactra lateralis, Tuomey \& Holmes, Pleiocene Foss. So. Ca., p. 97, pl. 23, fig. 9.

Mactra lateralis, Say's Conch. U. S., (Binney,) p. 101.

Description. Shell small, sub-triangular, smooth, or finely marked by the lines of growth, sub-equilateral; buccal margin rounded; anal margin prolonged, pointed; buccal region flat, heart shaped.-T. \& $H$.

This is also a common shell on the coast from Massachusetts to Florida.

Plate VII. Fig. 9, Natural size.

Museum, College of Charleston; Cabinet F. S. H. 


\title{
Genus, GNATHODON-GraY.
}

\author{
G N A T H O D O N $\quad$ C U N E A T U S.
}

Plate VII. Fig, 10.

Gnathodon cuneatus, Gray, Sowerby Gen., fig. 83.

Rangia cyrenoides, Desmoulins.

Gnathodon Grayii, Con., Foss. Ter. Form., p. 23, pl. 13, fig. 1.

Gnathodon Grayii, Tuomey \& Holmes, Pleiocene Foss. So. Ca., p. 99.

Gnathodon minor, Con., Sill. Am. Jour. Sci., Vol. 42, pl. 2, fig. 14.

Description. Shell ovate, ventricose, inequilateral, thick; buccal margin obtusely rounded, anal margin produced, angular, cuneiform ; umbones produced, prominent, eroded; epidermis olive-brown ; margin of valves acute, simple; pallial sinus, short, ovate, outline commencing near the middle of the inferior muscular impression; hinge-teeth two in each valve, anterior to the cartilage-pit, which is central, deep, and ovate; excavation extending under dorsal margin nearly to the beaks; the front tooth of the left valve angular, bifurcated, large, beautifully crenulated externally, and at the base within that of the right valve, triangular, massive, and crenulated on the outside only; the hind tooth in both valves small and simple, that of the right is cleft deeply to receive the tooth of left valve; lateral teeth one in each valve, elongated, slightly curved; anterior ends dilated; dorsal sides beautifully crenulated; a narrow elongated ridge resembling a tooth, and crenulated on the inferior side of the anterior end, extends parallel to the lateral tooth on the dorsal side of the right valve.

GNathodon cuneatus, is a variable shell; specimens corresponding to the various descriptions given of the synonyms above named, may be had from the Post-Pleiocene beds of South-Carolina; I therefore do not hesitate to refer them all to one species.

Those from the Pleiocene have their representative in the Post-Pleiocene as well as the recent forms from the Gulf coast; and it would be as easy to make a half dozen species as two or three; for example, that of the Post-Pleiocene, from which the figure in our plate is taken, differs not only in form and size, but the pallial sinus is ovate, short, and transverse, whilst that of the recent is angular or sub-lanceolate, and ascending. Shell beds of the Post-Pleiocene like those found on the surface at Mobile and in Southern Alabama, composed entirely of this species, and referred to the recent period by Professor Tuomey,* underlie the city of Charleston, about sixteen feet below the surface.

It is no longer an inhabitant of the bays of South-Carolina, but common on the Northern marshes of the Gulf of Mexico.

Plate VII. Fig. 10.

Locality. Charleston. Museum, College of Charleston; Cabinet F. S. H. 


\section{Genus, MULINIA.}

\section{ULINIA MILESII.-(New Species.)}

Plate VII. Fig. 11.

Description. Shell, oblong-oval, transverse, thin; buccal side produced, sub-angulated, round at point; anal side regularly rounded, somewhat tumid; base emarginated, com'pressed, compression extending upwards towards umbones; anterior dorsal margin sub-rectilinear; beaks hardly prominent; $V$ tooth strong, recipient cavity for lateral teeth, long, simple; cartilage-pit sub-angular.

This species cannot be confounded with any other shell from the Post-Pleiocene or coast of South-Carolina; its distinct $\mathrm{V}$ tooth, elongated anterior side, compressed pallial margin, round and tumid anal side, readily characterise it. The left valve only has yet been discovered. I take pleasure in dedicating it to my friend the adjunct Professor of Anatomy in the Medical College of Charleston, Dr. Francis T. Miles.

Plate VII. Fig. 11, Natural size.

Cabinet F. S. H.

$$
\begin{gathered}
\text { Genus, RA ̈̈TA.-Gray. } \\
\text { RA ËTA LINEATA. } \\
\text { Plate VII. Fig. } 12 .
\end{gathered}
$$

Lutraria lineata, Say, Jour. Acad. Nat. Sci., Vol. 2, p. 310.

Lutraria lineata, Am. Conch., pl. 9.

Lutraria lineata, Con., Am. Marine Conch., p. 47.

Lutraria lineata, Ravenel, Cat. Recent Shells, p. 2.

Lutraria lineata, De Kay, Zool. New-York, Art. Mollusca, p. 232.

Lutraria lineata, L. R. Gibbes, Tuomey's Geol. So. Ca., appendix, p. xxii.

Lutraria papyracea, Lamk., An. sans Vert., Vol. 6, p. 93.

Lutraria papyratia, Con., Am. Conch., pl. 10.

Raëta papyracea, Con., M.S.S.

Raëta papyracea, Adams, Gen. Mollusca, Vol. 2, p. 386.

Lutraria lineata, Say's Conch. U. S. (Binney), p. 158.

Description. Shell transversely sub-oval, thin, whitish, tinged with ferruginous; posterior hiatus patulous; anterior hiatus linear and commencing below the hinge slope; 
hinge slope with a rectilinear profile, and flattened oblong subcordate surface; valves unequally wrinkled; posterior margin rounded, shorter than the opposite margin, with a reflected edge, and sub-marginal carinated line; hehind the middle of the disk, and some distance before the elevated line, is a broad vitta of hardly perceptible longitudinal lines; within, a little undulated; posterior margin glabrous, with an obtusely indented, submarginal line, corresponding with the exterior or carinated one."-Say.

Rä̈ta Lineata, is not uncommon on the Southern coast, nor in the Post-Pleiocene as a fossil.

Plate V.II. Fig. 12, Natural size.

Locality. Simmons'.

Museum, College of Charleston; Cabinet F. S. H.

\section{R A ËTA CANALICULATA.}

Plate VII. Fig. 13.

Lutraria canaliculata, Say, Jour. Acad. Nat. Sci., Vol. 2, p. 311.

Lutraria canaliculata, Con., Am. Marine Conch., p. 46, pl. 10, fig. 1.

Lutraria canaliculata, De Kay, Zool. New-York, Art. Mollusca, pl. 31, fig. 298.

Lutraria canaliculata, Ravenel, Cat. Recent Shells, p. 2.

Lutraria canaliculata, L. R. Gibbes, Tuomey's Geol. So. Ca., appendix, p. xxii.

Raëta canaliculata, Con., M.S.S.

Raëta canaliculata, Adams, Gen Moll., Vol. 2, p. 386, pl. 102, figs. 4, $4 a$.

Lutraria canaliculata, Say's Conch. U. S., (Binney,) p. 102.

Description. Shell transversely-oval, orbicular, very thin and fragile, white, inflated; valves equally, concentrically, and regularly grooved, with very faint parallel lines within the grooves; posterior margin short, sub-cuneiform, compressed; a marginal, longitudinal, irregular, sub-impressed line, between which and the edge, the grooves become mere wrinkles; posterior slope sub-rectilinear, hiatus considerable; anterior margin regularly curved, the slope convex; within grooved as without; anterior angle glabrous.-Say.

'This is a common shell of the Southern coast; in the Post-Pleiocene beds of Simmons' Bluff, we find numberless specimens in a perfect state, forming little groups of a dozen or more individuals still in situ, occupying the vertical position in which they lived.

Plate VII. Fig. 13.

Locality. Simmons'. Muscum, College of Charleston; Cabinet F. S. H. 


\title{
Genus, MEsodesMA-Desh.
}

Description. Shell small, trigonal, thick, very inequilateral, concentrically and finely ribbed; ribs regularly rounded; anterior margin rounded regularly, deeper than posterior; anal margin slightly compressed in the middle; posterior extremity of shell prolonged, narrowed, wedge-shaped.

This shell closely resembles Mesodesma arctata, Gould; the anterior extremity is not truncated, but regularly rounded; the concentric striæ, or finely rounded ribs, are quite characteristic; I have found a few shells in the sands of our sea-beaches, but none with the animal.

Plate VI. Fig. 10, Natural size.

Locality. Simmons'; St. Paul's.

Cabinet F. S. H.

\author{
Genus, TELLINA.-LinN. \\ TELLI NA F L E X U O S A. \\ Platre VII. Fig. 14.
}

Tellina flexuosa, Say, Jour. Acad. Nat. Sci., Vol. 2, p. 303.

Tellina flexuosa, De Kay, Zool. New-York, Art. Mollusca, p. 210.

Tellina flexuosa, L. R. Gibles, Tuomey's Geol. So. Ca., appendix, p. xxi.

Tellina flexuosa, Tuomey of Holmes, Pleiocene Foss. So. Ca., p. 90, pl. 22, fig. 7.

Description. Shell sub-orbicular, surface obliquely sculptured, with very regular parallel lines; longitudinal striæ none; transverse wrinkles minute; buccal margin longer than anal, and less obtusely rounded; beak placed behind the middle, not prominent. $-T$. \& $H$.

This shell is often found in the sands of our sea-coast.

Plate VII. Fig. 14, Natural size.

Locality. Simmons'.

Museum, College of Charleston; Cabinet F. S. H. 
PERONAODERMA ALTERNATA.

Piate Vili. Fig. 1.

Tellina a]ternata, Say, Jour. Acad. Nat. Sci., Yol. 2, p. 275.

Tellina aliernata, Say, Amn. Conch., pl. 65, fig. 1.

Tellina alternata, Rovenel, Cat. Recent Shells, p. 4.

Tellina alternata, De Kay, Zool. New-York, Art. Mollusca, p. 211.

Tellina alternata, L. R. Gibbes, Tuomey's Geol. So. Ca., appendix, p. xxi.

Tellina alternata, Tuomey \& Holmes, Pleiocene Foss. So. Ca., p. 89, pl. 22.

Tellina alternata, Say's Conch. U. S., (Binney,) pp. 96, 228.

Peronæolerma alternata, Adams, Gen. Recent Shells, Vol. 2, p. 396.

Description. Shell compressed, oblong, narrowed and angulated before; with numerous parallel, equal, equidistant, impressed, concentric lines, which on the anterior margin are alternately obsolete; interstitial spaces flat.-T. \& $H$.

A callous line which is sometimes obsolete, passes from behind the linge to the inner margin of the posterior cicatrix, and another from before the hinge to the inner margin of the anterior cicatrix. Anterior hinge-slope declining in a somewhat concave line to an obliquely truncated tip.

This is a common species, living on the coast of South-Carolina and Georgia, and not unfrequent on the beach of Florida.

Plate VIIJ. Fig. 1, Natural size.

Locality. Simmons'; Abbapoola Creek, John's Island.

Museum, College of Charleston; Cabinet F. S. H.

\section{A NGULUS POLITA. \\ PLA'E VIII. F!̣. 2.}

Tellina nolita, Say, Jour. Acad. Nat. Sci., Vol. 2, p. 276.

Tellina polita, Ravenel, Cat. Coll. Shells, p. 4.

Tellina polita, L. R. Gibbes, Tuomey's Geol. So. Ca., appendix, p. xxi.

Tellina polía, De Kay, Zool. New-York, Art. Mollusca, p. 210.

Tellina polita, Tuomey \& Holmes, Pleiocene Foss. So. Ca., p. 91, pl. 22, fig. 6.

Tellina polita, Say's Conch. U. S., (Binney,) pp. 97, 228.

Angulus polita, Adams, Gen. Recent Shells, Vol. 2, p. 398.

Description. Shell transversely sub-triangular, minutely and concentrically wrinkled; 
buccal margin rather shorter than ventral; basal margin nearly rectilinear from behind the middle to the anterior termination.-T.\& $H$.

Plate VIII. Fig. 2, Exterior of fossil shell, natural size.

Locality. Simmons'.

Museum, College of Charleston; Cabinet F. S. H.

\author{
PERONAA TENTA. \\ Plate ViII. Fig. 3.
}

Tellina tenta, Say, Amn. Conch., pl. 65, fig. 3. 1834

Tellina tenta, Adams, Boston Jour. Nat. Hist., Vol. 3, p. 332.

Tellina tenta, Gould, Invert. Mass., p. 68, fig. 43.

Tellina tenta, De Kay, Zool. New-York, Art. Mollusca, p. 210.

Tellina tenta, Stimpson, Shells New-England, p. 21.

Tellina tenta, Ravenel, Amn. Conch., Say's observations on pl. 65.

Tellina tenta, Say's Conch. U. S., (Binney,) p. 228.

Peronæa tenta, Adams, Gen. Recent Shells, Vol. 2, p. 399.

Description. Shell transversely oblong, fragile, smooth externally; polished within and radiately striated; striæ almost obsolete; beaks behind the middle, slightly elevated; buccal side regularly rounded; anal side sub-angular, curved to the right, gaping, tip obviously truncated; hinge delicate, with two cardinal teeth in right valve, and one in the left; lateral teeth, one in right valve, with corresponding depressure in the left.

Living on the coast of United States, from Cape Cod to Florida, but rarely found fossil in the Post-Pleiocene.

Plate VIII. FIG. 3, Left valve, natural size.

LOCALITy. Simmons'.

Museum, College of Charleston; Cabinet F. S. H. 
TELLINA CAYENNENSIS.

Plate ViII. Fig. 4.

Psammobia cayennensis, Lam., An. sans Vert., Vol. 6, p. 177.

Solen constrictus, Brug., Cat. Mem. de la Soc. d'Hist. Nat., p. 126, No. 3.

Tellina intastriata, Say, Jour. Acad. Nat. Sci., Vol. 5, p. 218.

Tellina intastriata, De Kay, Zool. New-York, Art. Mollusca, p. 211.

Tellina cayennensis, Jay, Cat. Coll. Shells, 4th Ed., No. 536, p. 25.

Tellina intastriata, Say's Conch. U. S., (Binney,) p. 125.

Description. Shell sub-ovate, ventricose, transversely and distinctly striated; posterior end wrinkled; radiating striæ nearly obsolete externally, within distinct; anterior margin regularly rounded, and continuous with basal margin ; posterior end angular, sub-rostrated, tip rounded, curved to the right; within smooth, not striated; posterior dorsal slope oblique, rectilinear, with a fold extending from beak to basal margin.

Telina cayennensis is living on the coast of South-Carolina, but only found near the mouth of the Santee River, where the water is brackish.

Plate VIII. Fig. 4, Valves, natural size.

Museum, College of Charleston; Cabinet F. S. H.

\section{Genus, TELLID O R A.—M ̈̈ R н.}

TELLIDORA L U N U A T A.

Plate IX. Figs. 6 to $7 d$.

Tellidora lunulata, Adams, Gen. Recent Mollusca, Vol. 2, p. 401.

Description. Shell sub-triangular, inequivalve, inequilateral; surface of valves concentrically plicated; beaks prominent, slightly curved laterally; lateral slopes strongly produced, dentated at their edges; two primary teeth in right valve, one in the other; lateral teeth, two in each valve.

Tellidora lunulata no longer exists on the coast of South-Carolina; T. Burnetti, of Brod. \& Sow., now living on the Pacific shores of California, is nearly allied to it. In our fossil shell, the left valve is concave, and the right valve flat; the dorsal anterior slope is almost rectilinear, in some specimens slightly, and convexly curved, and the posterior slope 
slightly, and concavely curved; whereas, in the recent species, T. Burnetri, the left valve is flat, the right concave, and the posterior dorsal margin very deeply curved; the dentations are also more profound. We have been careful in giving a number of good figures of these two species, as they have been confounded for a long time.

Plate IX. Fig. 6, T. Burnetti, left valve.

" $6 a$, T. Burnetti, interior, right valve.

" 6b, To show convexity of right valve.

“ 7, T. lunulata, right valve.

“ 7a, T. lunulata, left valve.

“ $7 b$, Interior, left valve.

" $7 c$, Interior, right valve.

" $7 d$, To show convexity of left valve.

Locality. Simmons'; Brown's, St. Andrew's.

Museum, College of Charleston; Cabinet F. S. H.

Genus, MACOMA.-Lен сн.

IN A COM $A$ F U SCA.

PIATE VIII. FIG. 5.

Psammobia fusca, Say, Jour. Acad. Nat. Sci., Vol. 5, p. 220.

Sanguinolaria fusca, Con., Am. Mar. Conch., p. 34, pl. 7, fig, 1.

Sanguinolaria fusca, Gould, Invert. Mass., p. 66, fig. 42.

Sanguinolaria fusca, De Kay, Zool. New-York, Art. Mollusca, p. 21.2, pl. 32, fig. 304. Sanguinolaria fusca, Ravenel, Cat. Coll. Shells, p. 3.

Sanguinolaria fusca, L. R. Gibbes, Tuomey's Geol. So. Ca., appendix, p. xxi.

Sanguinolaria fusca, Jay, Cat. Coll. Shells, 4th Ed., No. 565.

Tellina fusca, Stimpson, Shells New-England, p. 20.

Macoma fusca, Adams, Gen. Recent Mollusca, Vol. 2, p. 400.

Psammobia fusca, Say's Conch. U. S., (Binney,) p. 126.

Description. Shell thin, compressed, transversely ovate, equilateral, concentrically and distinctly striated; striæ somewhat wrinkled; beaks small, not prominent, central; buccal margin rounded; anal margin narrowed, somewhat pointed; a fold extends from beaks to point of anal margin, which is obtusely rounded; two small unequal teeth in each valve. 
This shell is common along the whole Atlantic coast of the United States, but very rare in the Post-Pleiocene beds of South-Carolina.

Plate VIII. Fig. 5.

Locality. Simmons'. Museum, College of Charleston; Cabinet F. S. H.

\section{Genus, SERRULA.-LIN.}

\section{SERRULA VARIABILIS.}

Plate vili. Fig. 6.

Donax variabilis, Say, Jour. Acad. Nat. Sci., Vol. 2, p. 305.

Donax variabilis, Say, Am. Conch., pl. 61, fig. 1.

Donax variabilis, De Kay, Zool. New-York, Art. Mollusca, p. 212.

Donax variabilis, Ravenel, Cat. Coll. Shells, p. 4.

Donax variabilis, L. R. Gibbes, Tuomey's Geol. So. Ca., appendix, p. xxi.

Donax variabilis, Tuomey \& Holmes, Pleiocene Foss. So. Ca., p. 95, pl. 23, fig. 6.

Serrula variabilis, Adams, Gen. of Recent Shells, Vol. 2, p. 406.

Donax variabilis, Say's Conch. of U. S., (Binney,) pp. 99, 226.

Description. Shell triangular; longitudinally striated, with equal, parallel, regular, impressed, but indistinct lines; buccal margin obliquely truncated, cordate, suture subconvex; anal margin nearly rectilinear, suture indented; pallial margin a little prominent, beyond a regular curve, near the middle; interior edge crenate- $-T$. \& $H$.

This is an abundant recent species upon the sea shores of the South, and is found fossil also in great quantities in the Post-Pleiocene beds.

Plate VIII. Fig. 6, Fossil, natural size.

Locality. Abbapoola; Simmons'.

Museum, College of Charleston; Cabinet F. S. H. 


\title{
Genus, ABRA.- L EACH.
}

\author{
ABRA 2 Q Q UALIS. \\ PLATE VIII. Fig. 7.
}

Amphidesma æqualis, Say, Jour. Acad. Nat. Sci., Vol. 2, p. 307.

Amphidesma æqualis, Con., Foss. Ter. Form., p. 76, pl. 43, fig. 9.

Amphidesma æqualis, d'Orb., Prod. de Paleontologie, Vol. 3, p. 101, No. 1886.

Amphidesma æquale, Say, Am. Conch., pl. 28.

Amphidesma æquale, Ravenel, Cat Coll. Shells, p. 3.

Amphidesma æqualis, L. R. Gibbes, Tuomey's Geol. So. Ca., appendix, p. xxii.

Amphidesma æqualis, Tuomey \& Holmes, Pleiocene Foss. So. Ca., p. 93, pl. 23, fig. 3.

Amphidesma æqualis, Say's Conch. U. S., (Binney,) pp. 100, 182.

Description. Shell obliquely-orbicular, ventricose, smooth; beaks sub-medial, nearest to anal end; umbonial slope sub-marginal, slightly carinated; anal side somewhat warped or bent.

This is a recent species on the shores of South-Carolina, Florida, and Alabama, and fossil in the Post-Pleiocene of this State.-T.\& $H$.

Plate VIII. Fig. 7, Natural size.

Locality. Simmons'.

Museum, College of Charleston.

\section{A B R A A N G U L A T A.- (New Species.) \\ Plate VIII. Fig. 8.}

Description. Shell sub-orbicular, equivalve, sub-equilateral, convex, anteriorly rounded, posteriorly angulated towards basal margin; anal side with a raised line or warped ridge, extending from beak to angle of margin; surface minutely and concentrically wrinkled; wrinkles distinct towards basal margins, but sometimes obsolete on umbones; beaks distinct, somewhat acute; within radiately striated; striæ often obsolete, or not visible but with the aid of a lens, terminating, at basal margin; gives it a finely serrated appearance; pallial impression distinct; lunule deep and broad, distant from margin, projecting up into the middle of the cavity; primary teeth two in each valve, no lateral teeth, but anterior margin of right valve has a projecting rim or elevated edge, which extends from the beak half way down to basal margin; ligamental-cavity sub- 
fusiform, parallel with posterior slope. This shell resembles AmpHidesma punctata, of Say, but it is readily distinguished by its smooth, not punctured surface, and angular posterior side. It is abundant in the Post-Pleiocene, and though dead shells are often found on our beaches, we have not yet discovered a living specimen on the coast of SouthCarolina.

Plate VIII. FIG. 8, Valves, natural size.

Locality. Simmons'; Abbapoola Creek; Artesian Well, Charleston.

Museum, College of Charleston; Cabinet F. S. H.

Genus, SEMELE.-Schumacker.

SEMELE ORBICULATA.

Plate VIII. Fig. 9.

Amphidesma orbiculata, Say, Jour. Acad. Nat. Sci., Vol. 2, p. 307.

Amphidesma orbiculata, Ravenel, Cat. Coll. Shells, p. 3.

Amphidesma orbiculata, De Kay, Zool. New-York, Art. Mollusca, p. 237.

Amphidesma orbiculata, L. R. Gibbes, Tuomey's Geol. So. Ca., appendix, p. xxii.

Amphidesma orbiculata, Tuomey \& Holmes, Pleiocene Foss. So. Ca., p. 94, pl. 23, fig. 4.

Semele orbiculata, Adams, Gen. Recent Shells, Vol. 2, p. 411.

Amphidesma orbiculata, Say's Conch. U. S., (Binney,) p. 100.

Description. Shell orbicular, sub-compressed; surface finely marked with concentric lines of growth, which are interrupted irregularly with raised sub-laminated concentric lines; buccal margin obtusely undulated; interior ligamental-cavity profound, fusiform, parallel with marginal slope, and extending from tip of beak.

In young shells, longitudinal, radiating, and obsolete lines are distinctly seen intersecting the lines of growth, but in older specimens a few lines only are visible upon the buccal folds or undulations. $-T$. \& $H$.

This species is abundantly fossil in the Post-Pleiocene, and is recent on the coast of the State.

Plate VIII. Fig. 9, Exterior of shell.

Locality. Simmons'.

Museum, College of Charleston. 


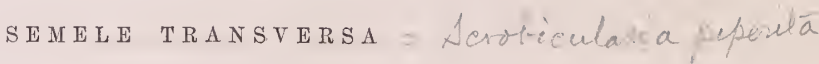

Plate VIII. Fig. 10.

Amphidesma transversa, Say, Am. Conch., pl. 28

Amphidesma transversa, De Kay, Zool. New-York, Art. Mollusca, p. 237.

Amphidesma transversa, Say's Conch. U. S., (Binney,) p. 181.

Description. Shell thin, sub-oval, nearly equilateral, compressed; buccal and anal margins sub-equally rounded; beaks slightly prominent, basal margin regularly rounded.

This shell is now living on the Northern coast of the United States. Mr. Say obtained a specimen from the coast of Georgia, which he says was somewhat worn; was it a Post-

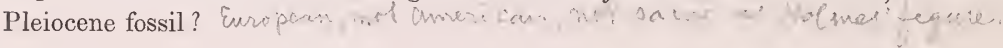

Plate VIII. Fig. 10, Fossil, natural size. int of day

Locality. Abbapoola Creek. Museum, College of Charleston; Cabinet F. S. II.

\author{
SE II E L E R A I A TA. \\ Plate ViII. Fie. 11.
}

Amphidesma radiata, Say, Jour. Acad. Nat. Sci., Vol. 5, p. 220.

Amphidesma radiata, Say, Conch. U. S., (Binney,) p. 127.

Description. Shell transversely oval, orbicular, a little compressed; apex nearly central, a little prominent; posterior slope somewhat concave near the beak; anterior slope rectilinear to the middle; disk somewhat regularly wrinkled transversely, and with minute longitudinal striæ; anterior sub-margin, with a very slight obtuse undulation; cardinal teeth two in each valve, elevated, slender, unequal; lateral teeth very distinct; interior ligamental cavity profound, fusiform.-Say.

Our specimen is a single valve only of a young shell. It is not known to be living upon the Carolina coast, but Mr. Say had specimens from the shores of East Florida, and one shell from the coast of Georgia.

Plate VIII. Fig. 11, Shell, natural size.

Cabinet F. S. H. 


\title{
Genus, CUMINGIA.-Sow. \\ C U M I GIA TELLINOIDES. \\ Plate Vili. Fig. 12.
}

Mactra tellinoides, Con., Jour. Acad. Nat. Sci., Vol. 6, p. 258, pl. 11, figs. $2,3$.

Cumingia tellinoides, Con., Foss. Ter. For., p. 28, pl. 15, fig. 4.

Lavignon tellinoides, d' Orb., Prod. de Paleontologie, Vol. 3, p. 101, No. 1891.

Lavignon tellinoides, Tuomey \& Holmes, Pleiocene Foss. So. Ca., p. 92, pl. 23, fig. 1.

Cumingia tellinoides, Adams, Gen. Recent Shells, Vol. 2, p. 412.

Description. Shell ovate, thin, fragile, with numerous raised concentric striæ; one end regularly rounded, the other slightly compressed and somewhat pointed at the extremity; lateral teeth distinct in one valve, in the other obsolete.-T. \& $H$.

Conrad says this shell inhabits the Northern Atlantic coast of the United States.

Plate VIII. Fig. I2, Exterior and interior of shell, natural size.

Locality. Simmons'. Museum, College of Charleston; Cabinet F. S. H.

\author{
Genus, ENSIS.-ScH U. \\ EN S I S EN SIS. \\ Plate Vili. Fig. 13.
}

Solen ensis, Linn., Syst. Nat., 1114.

Solen ensis, Lamk., An. sans Vert., 2d Ed., Vol. 6, p. 55.

Solen ensis, Con., Marine Conch., pl. 5, fig. 1.

Solen curvus, Lister, Conch., t. 411, fol. 257.

Solen ensis, Gould, Invert. Mass., p. 28.

Solen ensis, Ravenel, Cat. Coll. Shells, p. 2.

Solen ensis, L. R. Gibbes, Tuomey's Geol. So. Ca., appendix, p. xxii.

Solen ensis, Tuomey \& Holmes, Pleiocene Foss. So. Ca., p. 101, pl. 24, fig. 3.

Solen ensis, Stimpson, Shells New-England, p. 22.

Ensis ensis, Adams, Gen. Recent Shells, Vol. 2, p. 342.

Description. Shell sword-shaped; dorsal and pallial margins parallel; buccal and 
anal margins sub-truncate. The genus is distinguished from solex by the number of teeth in the hinge, and by the curved form of the valves.

This is a well-known shell, living all along the coast of the United States.

Plate VIII. Fig. 13, Natural size, one valve broken.

Locality. Simmons'. Museum, College of Charleston; Cabinet F. S. H.

\author{
Genus, SILLIQUARIA. - S сним. \\ SILLIIQUARIA CARIBGA. \\ Plate VIII. Fig. 14.
}

Solecurtus caribœus, Blain, Dict. des Sci. Naturelle, Vol. 29, p. 240.

Solecurtus caribœus, Con., Marine Conch., p. 22, pl. 4, fig. 3.

Solecurtus caribœus, Gould, Invert. Mass., p. 30.

Solen caribœus, Ravenel, Cat. Coll. Shells, p. 2.

Solecurtus caribœus, L. R. Gibbes, Tuomey's Geol. So. Ca., appendix, p. xxii.

Solecurtus caribœus, Tuomey \& Holmes, Pleiocene Foss. So. Ca., p. 99, pl. 23, figs. 12 and 13. Solecurtus gibbus, Stimpson, Shells of New-England, p. 22.

Silliquaria gibba, Adams, Gen. Recent Shells, Vol. 2, p. 347.

Descriptiun. Shell oblong-oval, straight, gaping at both ends; buccal and anal margins obtusely rounded; pallial margin straight, slightly compressed near the middle, beaks nearly central, slightly elevated; hinge teeth two, three; sinus of pallial impression very deep, extending beyond the umbo.

Silliquaria caribea is found in the Pleiocene of South-Carolina; is very abundant in the Post-Pleiocene, and common in the recent state on the coast.

Plate VIII. Fig. 14, Valves, natural size.

Locality. Charleston; Simmons'; Abbapoola.

Museum, College of Charleston; Cabinet F. S. H. 


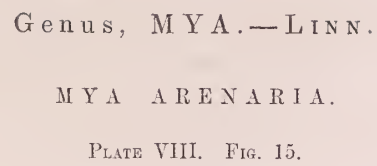

Mya arenaria, Linn., Syst. Nat., p. 1112.

Mya arenaria, Gould, Invert. Mass., p. 40.

Mya mercenaria, Say, Jour. Acad. Nat. Sci., Vol. 2, p. 313.

Mya acuta, Say, Jour. Acad. Nat. Sci., Vol. 2, p. 313.

Mya acuta, Say's Conch. U. S., (Binney,) p. 103.

Description. Shell transversely ovate, equivalve, sub-equilateral, tumid, gaping at both ends, surface wrinkled; anterior margin rounded; posterior margin produced, subacute, reflexed, without teeth; process for cartilage-pit in left valve large, of equal length and breadth, and projecting inwards and backwards; cartilage-pit of right valve without a process, but with a tooth-like projection behind it; its anterior margin reflexed; anterior muscular impression narrow, long, club-shaped, extending upwards towards the beaks; pallial impression distinct, irregularly scolloped; pallial sinus deep and broad.

Mya arenaria is the long clam of the Boston and New-York markets, alld does not exist on the coast of the Southern Atlantic States. The clams of the Charleston market are Venus mercenaria, and Venus Mortoni. The Myas found upon our beaches are undoubtedly fossils of the Post-Pleiocene, and this we infer not only from their old and water-worn appearance, but from Mr. Say's description of his species "Acuta," which he says was from this coast. Like "M. AcUTA," our fossil is more acutely pointed posteriorly than the recent shell.

Plate VIII. Fig. 15, Valves, natural size.

Locality. 'The beaches of the coast; Simmons'; Abbapoola, \&c.

Museum, College of Charleston; Cabinet F. S. H.

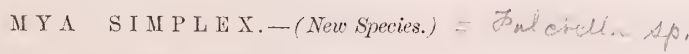

Plate VIII. Fig. 16.

Description. Shell transversely ovate, convex, not tumid, inequilateral, concentrically striated; anterior and posterior margins obtusely rounded, the former narrowest; pallial margin sub-rectilinear; posterior dorsal margin slightly curved; cartilage-pit excavated, 
and having a tooth-like process, distinct and prominent behind; muscular and pallial impressions simple, the latter indistinct.

This small species is readily distinguished by its sub-equal posterior and anterior margins, the anterior being narrowest; beaks not prominent forward of the middle, and by the prominent tooth-like process of the right valve; it differs also from M. ARENaRIA, in having the anterior muscular impression simple, and not club-shaped.

Not known to exist in the recent state.

Plate VIII. Fig. 16.

Locality. Simmons'. Nhuseum, College of Charleston; Cabinet F. S. H.

\author{
Genus, CORBULA-Brug. \\ CORBULA CONTRACTA. \\ Plate Vili. Fig. 17.
}

Corbula contracta, Say, Jour. Acad. Nat. Sci., Vol. 2, p. 312.

Corbula contracta, Ravenel, Cat. Coll. Shells, p. 3.

Corbula contracta, Gould, Invert. Mass., p. 43.

Corbula contracta, L. R. Gibbes, Tuomey's Geol. So. Ca., appendix, p. xxii.

Description. Shell transversely sub-ovate; valves sub-equal, regularly and profoundly striated transversely; beaks not prominent, nearly central, one side rounded and the other sub-acute; basal margin contracted near the middle, one half of the length of one valve concealing one half of the edge of opposite valve.-Say.

I have not seen a living specimen, though the shells are common along the beaches of the Southern sea-coast.

Plate VIII. Fig. 17, Shell, natural size.

Locality. Simmons'; Abbapoola; Charleston, Artesian Well. Museum, College of Charleston; Cabinet F. S. II. 


\section{Genus, SAXICAVA.-Fleuriau de Bellevue.}

\section{Genus, BYsSOMYA.-Cuv.}

\section{SAXICAVA FRAGILIS.-(New Species.)}

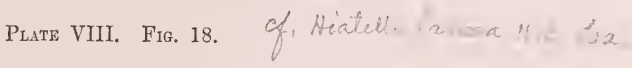

Description.—Shell oblong, fragile, concentrically striated, somewhat laminated; anterior and posterior margins obtusely rounded; dorsal margin straight, or slightly curved towards posterior end; pallial margin compressed in the middle; umbones anterior, depressed; pallial impression distinct, simple, at a distance from margins ; cardinal tooth in both valves, prominent, nodulous.

We have the right and left valve of this shell from the Post-Pleiocene; it is not known on the coast.

Plate VIII. Fig. 18, Right valve, natural size.

Locality. Simmons'.

Cabinet F. S. H.

\section{Genus, PHOLAS.-LinN.}

\section{PHOLAS TRUNCATA.}

Plate IX. Fig. 4.

Pholas truncata, Say, Jour. Acad. Nat. Sci., Vol. 2, p. 223.

Pholas truncata, De Kay, Zool. New-York, Art. Mollusca, p. 248, pl. 34, fig. 223.

Pholas truncata, Ravenel, Cat. Coll. Shells, p. 2.

Pholas truncata, L. R. Gibbes, Tuomey's Geol. So. Ca., appendix, p. xxii.

Pholas truncata, Say's Conch. U. S., (Binney,) p. 107.

Description. Shell transversely oblong, sub-pentangular; anterior margin rostrated, obtusely cuneiform in the middle; posterior margin broadly truncated at tip; valves transversely wrinkled and longitudinally striated, muricated, particularly on the anterior side, with small erect scales, which are not arched beneath; posterior margin from a line extending from the beak to the inferior angle of the truncature, destitute of the striæ and mutic; hinge callous, formed of the duplicature of the hinge-margin, and destitute of cells; a small tooth upon the inner margin, projecting backwards; dentiform process curved, prominent, slender, flat.-Say.

Plate IX. Fig. 4, Shell, natural size.

Locality. Simmons'.

Museum, College of Charleston; Cabinet F. S. H. 


\title{
PHOLAS COSTATA.
}

Plate IX. Figs. 1 and $1 a$.

Pholas costata, Linn., Syst. Nat., 1111.

Pholas costata, Lam., An. sans Vert., VI., 45.

Pholas costata, Wood, Gen. Conch., pl. 15, figs. 1 and 2.

Pholas costata, Gould, Invert. Mass., p. 26.

Pholas costata, Ravenel, Cat. Coll. Shells, p. 2.

Pholas costata, L. R. Gibbes, Tuomey's Geol. So. Ca., appendix, p. xxii.

Pholas costata, Tuomey \& Holmes, Pleiocene Foss. So. Ca., p. 102, pl. 24, fig. 4.

Description. Shell large, thin, oblong-ovate; buccal margin rounded, anal margin more pointed; dorsal margin reflected over the umbones; ribs radiating, with coarse lines of growth, producing tooth-like elevations at regular intervals on each rib.

This is the most common of the three species of PHOLADIDE on the Southern coast, and is abundant in the harbors of this State. It often attains the width of six inches.

Plate IX. Fig. 1, Fossil, natural size; back view, showing accessory valve.

" $1 a$, Side vien, left valve.

Locality. Simmons'. Museum, College of Charleston.

\author{
Genus, DACTYLINA.-Gray. \\ D A C T YLINA O BLONGA TA. \\ Plate IX. Fig. 2.
}

Pholas oblongata, Say, Jour. Acad. Nat. Sci., Vol. 2, p. 320.

Pholas oblongata, Ravenel, Cat. Coll. Shells, p. 2.

Pholas oblongata, L. R. Gibbes, Tuomey's Geol. So. Ca., appendix, p. 22.

Pholas oblongata, Tuomey \& Holmes, Pleiocene Foss. So. Ca., p. 103, pl. 24, fig. 1.

Description. Shell oblong-ovate, inflated, transversely and longitudinally striated; striæ muricated, and elevated on the buccal side into ribs; buccal margin acutely rounded; anal margin compressed; dorsal margin anteriorly reflexed, forming a cavity; hinge callous, minutely striated transversely and longitudinally, and with about twelve cells.-T.\&. $H$. 
This shell is easily distinguished from P. costata by the hinge-plates, which are cellular beneath; the two dorsal valves are lanceolate and placed side by side, which is characteristic of the genus. It is living on the coast of South-Carolina, Georgia, and Florida, and is quite common.

Plate IX. Fig. 2, Natural size; side vien.

Locality. Simmons'.

Museum, College of Charleston; Cabinet F. S. HT.

Genus, MARTESIA.-LEach.

M A R T E I A C U N E I F O R M I S.

Plate IX. Fig. 3.

Pholas cuneiformis, Say, Jour. Acad. Nat. Sci., Vol. 2, p. 322.

Pholas cuneiformis, Ravenel, Cat. Coll. Shells, p. 2.

Pholas cuneiformis, L. R. Gibbes, Tuomey's Geol. So. Ca., appendix, p. xxii.

Pholas cuneiformis, De Kay, Zool. New-York, Art. Mollusca, p. 248.

Pholas cuneiformis, Say's Conch. U. S., (Binney,) p. 108.

Martesia cuneiformis, Adams, Gen. Recent Mollusca, Vol. 2, p. 331.

Description. Shell sub-cuneiform; anterior margin nearly closed, transversely truncated from the hinge; the surface transversely striated in an undulated manner, with elevated, minutely crenate lines; the intestitial lines smooth; these lines partially interrupt a profoundly impressed longitudinal sulcus which passes from the beak to near the middle of the base; the inferior portion of this margin is destitute of striæ; posterior margin attenuated by nearly rectilinear edges to a rounded tip; surface transversely wrinkled; hinge callous, composed of the reflected margin which forms a cavity before, and is destitute of cells; dentiform process incurved, slender filliform; hinge-plate ovate triangular, with a short projecting angle on the interior middle, and sub-acute behind; within, disk slightly contracted by an elevated line corresponding with the external sulcus.-Say.

The dorsal valve in this genus is single. Common on the coast of South-Carolina, and fossil in the Post-Pleiocene.

Plate IX. Fig. 3, Natural size.

Locality. Simmons'.

Museum, College of Charleston; Cabinet F. S. H. 


\section{Genus, TEREDO.-LINN.}

\section{Sub. Genus, X X LOTRYA.-LEACH.}

\section{XYLOTRYA PALMULATA.}

Plate IX. Fig. 5.

Teredo palmulatus, Lam., An. sans Vert., 2d Ed., Vol. 6, p. 38.

Teredo palmulatus, L. R. Gibbes, Tuomey's Geol. So. Ca., appendix, p. xxii.

Xylotrya palmulata, Adams, Gen. Recent Mollusca, Vol. 2, p. 333.

This shell, remarkable for perforating the bottom of ships, and known as the ship worm, is common in wood exposed to the waters of the bays and harbors along the coast. We have as yet found in the Post-Pleiocene only portions of the calcareous tubes with which their perforations are lined.

Plate IX. F1G. 5, Fragment of tube.

Locality. Artesian Well, Charleston.

Museum, College of Charleston.

Class, GASTEROPODA. Order, PTEROPODA. Family, CAVOLINID AE.

Genus, CAVOLINA.-Giöenı.

C A V OL I N A T U O M Y I.-(New Species.)

Plate IX. Figs. 8 to $8 e$.

Description. Shell somewhat globular, symmetrical, lateral fissures narrow, slightly curved, extending backwards into the short appendices; mouth large, but not so large as the cavity of shell, arched below, with a reflected lip; margin above irregular, waved; dorsal surface nearly as wide as it is long, radiately ribbed; ribs five, large, the two lateral ones almost obsolete, the three middle ones distinct, margins extending beyond that of the abdomen; apex slightly produced, tumid.

I believe this is the first fossil specimen of CAvolina (Hyalæa) that has been discovered 
in the American Tertiary; as a memento of my late colleague, Professor Tuomey, who was present when I found this beautiful shell, I have given it his name.

Plate IX. FIG. 8, Shell, natural size.

" $8 a, A$ view of dorsal surface.

" $8 b$, Vien of abdominal surface.

" $8 c$, Side vien, showing lateral fissures.

“ $8 d$, End vien, showing mouth.

" 8 e, Apex.

Locality. Simmons'.

Cabinet F. S. H.

\section{Genus, STROMBUS.}

S T R O M B U S P U G I I S.

Plate X. Fig. 1 and $1 a$

Strombus pugilis, Linn., Syst. Nat., Ed. 12, p. 1209.

Strombus pugilis, Kiener, pl. 20.

Strombus pugilis, Lam., An. sans Vert., Vol. 9, p. 696.

Strombus pugilis, Dillwyn's Cat., Vol. 2, p. 664.

Description. Shell ponderous, turbinated, ventricose, transversely spinous, base and spire striated, lip rounded at the projecting summit, deeply notched in front.

No longer an inhabitant of the Carolina coast, but common on that of Florida.

Plate X. Fig. 1, Shell, natural size.

“ 1 a, Young shell.

Locality. Simmons' Bluff; St. Paul's.

Museum, College of Charleston.

Genus, MUREX.-Linn.

MUREX SPINACOSTATAS.-VALENC.

Plate X. Fig. 2.

Murex spinacostatas, Valenc.

Murex asperrimus, Ravenel, Cat. Coll. Shells, p. 15.

Murex —, L. R. Gibbes, Tuomey's Geol. So. Ca., appendix, p. xx.

Description. Shell sub-ovate, thick, transversely striated; spire prominent, whorls 16 
convex, with three or four continuous varices; varices spinous; aperture ovate, canal long, narrow, and slightly recurved.

Dead shells of this species often found upon the sea beaches, are supposed to belong otsbu-marine Post-Pleiocene beds, as they are fossil in appearance, and we know of no living specimen having yet been discovered upon our coast.

Plate X. Fig. 2.

Museum, College of Charleston; Cabinet F. S. H.

Genus, BURSA.

Sub. Genus, EUPLEURA.-H. \& A. Adans.

E U P L E U R A C A U D A T A.

Plate X. Fig. 3.

Ranella caudata, Say, Amn. Conch., pl. 48.

Ranella caudata, Gould, Invert. Mass., p. 297, fig. 204.

Ranella caudata, De Kay, Zool. New-York, Art. Mollusca, p. 139.

Ranella caudata, Ravenel, Cat. Coll. Shells, p. 15.

Ranella caudata, L. R. Gibbes, Tuomey's Geol. So. Ca., appendix, p. xx.

Apollon caudata, Tuomey \& Holmes, Pleiocene Foss. So. Ca., p. 142, pl. 28, fig. 3.

Eupleura Caudata, Adams, Gen. Recent Shells, Vol. 1, p. 107.

Description. Shell rhomboidal, thick, checkered with revolving lines and longitudinal ribs ; canal long and straight, aperture ovate, outer lip thick, margin with raised granules and lines.-T. \& $H$.

This shell is found all along the Atlantic coast from Buzzard's Bay to Florida, but it is more abundant at the South than the North.

Plate X. Fig. 3, Natural size.

Locality. Simmons'. Museum, College of Charleston; Cabinet F. S. H. 


\section{Genus, FAsCIOLARIA.- L A M. \\ FASCIOLARIA GIGANTEA.}

Plate X. Fig. 4.

Fasciolaria gigantea, Keiner, pl. 10 and 11.

Fasciolaria gigantea, Lam., An. sans Vert., Vol. 9, p. 435.

Fasciolaria gigantea, L. R. Gibbes, Tuomey's Geol. So. Ca., appendix, p. xx.

Fasciolaria gigantea, Tuomey \& Holmes, Pleiocene Foss. So. Ca., p. 152, pl. 30, fig. 9.

Fasciolaria gigantea, Adams, Gen. Recent Shells, Vol. 1, p. 150.

Descrrption. Shell fusiform, ventricose, transversely sulcated; spire prominent, acute, coronated, tuberculated; aperture ovate, continuous with canal, which is open and gracefully, but slightly curved; columella with three plaits.

This shell lives upon the coast of South-Carolina, and attains a great size.

Plate X. Fig. 4.。

Locality. Simmons' Bluff. Museum, College of Charleston; Cabinet F. S. H.

\section{FASCIOLARIA DISTANS.}

Plate X. Fig. 5.

Fasciolaria distans, Lam., An. sans. Vert., Vol. 9, p. 433.

Fasciolaria distans, Kiener, pl. 3.

Fasciolaria distans, Ravenel, Cat. Coll. Shells, p. 14.

Fasciolaria distans, L. R. Gibbes, Tuomey's Geol. So. Ca., appendix, p. xx.

Fasciolaria distans, Tuomey \& Holmes, Pleiocene Foss. So. Ca., p. 151, pl. 30, figs. 7 and 8.

Description. Shell fusiform, ventricose, longitudinally and finely striated; whorls marked transversely by dark colored and widely separated bands; sutures simple; spire prominent, acute; pillar with one plait.-T. \& $H$.

The dark bands are characteristic of this species; fossil specimens from the PostPleiocene retain these markings upon the surface.

It is common in a recent state upon the Southern coast.

Plate X. Fig. 5.

Locality. Simmon's.

Museum, College of Charleston; Cabinet F. S. H. 


\section{Genus, CANCELLARIA-Lam.}

\section{A N CELLARIA RETICULATA}

Plate X. Fig. 6.

Voluta reticulata, Linn., Syst. Nat., p. 1190.

Cancellaria reticulata, Lam., An. sans Vert., Vol. 9, p. 401.

Cancellaria reticulata, Ravenel, Cat. Coll. Shells, p. 14.

Cancellaria reticulata, L. R. Gibbes, Tuomey's Geol. So. Ca., appendix, p. xx.

Cancellaria reticulata, Tuomey \& Holmes, Pleiocene Foss. So. Ca., p. 142, pl. 28, fig. 16.

Descrirtion. Shell ovate, ventricose, thick; spire short, acute; whorls longitudinally and transversely grooved, obliquely reticulated; aperture sub-ovate, emarginated anteriorly, pointed at posterior extremity; labrum marked within with transverse ridges; columella straight, thick, obtuse, with strong oblique folds; pillar sub-umbilicated, suture distinct but compressed.-T. \& $H$.

This species is found recent on the Southern coast.

Plate X. Fig. 6.

Locality. Simmons'; Wando. Museum, College of Charleston; Cabinet F. S. H.

CA N CELLARIA VENUSTA.

Plate X. Fig. 7.

Cancellaria venusta, Tuomey \& Holmes, Pleiocene Foss. So. Ca., p. 144, pl. 23, fig. 18.

Description, Shell sub-fusiform, turrited, regularly cancellated; whorls with longitudinal, oblique ribs, sulcated transversely; inner lip reflexed on body whorl, smooth and with a distinct raised edge, extending from the base of the pillar and uniting above with the labrum in an arch; columella with two prominent folds slightly oblique; margin of outer lip scolloped, transversely ridged within with ten ridges; ridges equi-distant, straight, long; aperture profoundly ear-shaped, emarginate; suture profound.

This is the most graceful of all its congeners, and cannot be confounded with any other.-T.\& $H$.

Plate X. Fig. 7, Natural size.

Locality. Simmons' Bluff.

Museum, College of Charleston; Cabinet F. S. H. 


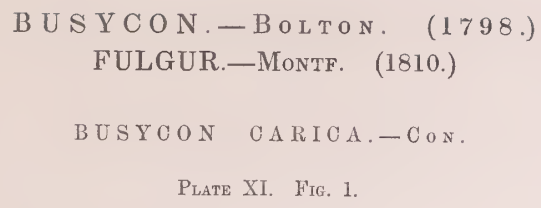

Murex carica, Gmel., Lister's Conch., pl. 880.

Pyrula carica, Lam., Ency. Mêth., pl. 436, fig. 2.

Pyrula carica, Lam., Woods' Index, pl. 26, fig. 83.

Pyrula auruana, Lam., An. sans Vert., Vol. 7, p. 138.

Pyrula carica, Ravenel, Cat. Coll. Shells, p. 14.

Pyrula carica, Adams, Boston Jour. Nat. Hist., Vol. 2, p. 269.

Pyrula carica, Gould, Invert. Mass., p. 296.

Pyrula carica, De Kay, Zool. New-York, Art. Mollusca, p. 141, pl. ix, figs. 192, 193.

Pyrula carica, Stimpson, Shells of New-England, p. 47.

Pyrula carica, L. R. Gibbes, Tuomey's Geol. So. Ca., appendix, p. xx.

Fulgur carica, Con., Pro. Acad. Nat. Sci., Vol. 7, p. 319.

Fulgur carica, Con., Cat. Shells Tert. Form., p. 2.

Busycon carica, Con., Pro. Acad. Nat. Sci., Vol. 8, p. 30.

Busycon carica, Tuomey \& Holmes, Pleiocene Foss. So. Ca., p. 145, pl. xxix, fig. 1.

Description. Shell pyriform, ventricose, thick, ponderous, transversely and finely striated; spire not turrited; suture not channeled, but having a series of triangular, compressed, tubercles above; larger ones around the prominent part of body whorl; outer lip simple, sharp; pillar lip flexuous, concave above.-T. \& $H$.

This shell is found in the Meiocene of Maryland, and in the Pleiocene of North and South Carolina. Is common in a recent state on this Atlantic coast and often attains a great size.

Plate XI. Fig. 1, Natural size.

Locality. Simmons'.

Museum, College of Charleston; Cabinet F. S. H.

\section{BUSYGON PERVERSUM.-CON.}

Plate XI. Fíg. 2

Buccinum ampullaceis ad sinistram convolutis, Lister, Conch., t. 907, 908.

Pyrula perversa, Lam., An. sans Vert., Vol. 9, p. 506. 
Pyrula perversa, Reeve, Conch. Icon., pl. 3, fig. 13. Pyrula perversa, Ravenel, Cat. Coll. Shells, p. 15. Pyrula perversa, Wood, Index, pl. 26, fig. 88. Pyrula perversa, L. R. Gibbes, Tuomey's Geol. So. Ca., appendix, p. xx. Busycon perversum, Con., Pro. Acad. Nat. Sci., Vol. 7, p. 31. Busycon perversum, Tuomey \& Holmes, Pleiocene Foss. So. Ca., p. 145, pl. xxix, fig. 3. Busycon perversum, H. \& A. Adams, Gen. Recent Mollusca, Vol. 1., p. 151, pl. 16, fig. 2.

Description. Shell pear-shaped, sinistral, ventricose; summit of each whorl inclined; prominent part of whorl coronated, tuberculated; suture not canaliculated, but distinct.

B. Peversum is common on the coast of South Carolina. The recent shells often have all the whorls coronated at their summits.

It is found in the Pleiocene of this State, and in the Post-Pleiocene of North-Carolina.

Plate XI. Fig. 2, Natural size.

Locality. Simmons'; Wadmalaw Sound.

Museum, College of Charleston; Cabinet F. S. H.

BUSTOON CANALICULATUM. - CON.

Plate XI. Fig. 3.

Buccinum ampullaceum, Lister, Conch., t. 878, fig. 2.

Murex canaliculatus, Linn, Martini, Vol. 3, p. 29, t. 67, figs. 742, 743.

Pyrula canaliculata, Reeve, Conch. Icon., pl. 8, fig 26.

Pyrula canaliculata, Adums, Boston Jour. Nat. Hist., Vol. 2, p. 269.

Pyrula canaliculata, Gould, Invert. Mass., p. 294, fig. 206.

Pyrula canaliculata, Ravenel, Cat. Coll. Shells, p. 14.

Pyrula canaliculata, De Kay, Zool. New-York, Art. Mollusca, p. 140, pl. ix, fig. 190.

Pyrula canaliculata, L. R. Gibbes, Tuomey's Geol. So. Ca., appendix, p. xx.

Pyrula canaliculata, Stimpson, Shells of New-England, p. 47.

Fulgur canaliculatum, Con., Pro. Acad. Nat. Sci., Vol. 6, p. 319.

Busycon canaliculatum, Con., Pro. Acad. Nat. Sci., Vol. 7, p. 30.

Busycon canaliculatum, Tuomey \& Holmes, Pleiocene Foss. So. Ca., p. 146, pl. xxix, fig. 2. Busycon canaliculatum, H. \& A. Adams, Gen. Recent Mollusca, Vol. 1, p. 151.

Description. Shell pear-shaped; whorls flattened on the summit, covered with revolving lines; body-whorl tumid, terminating in a long canal; angle of each whorl 
nodular, suture deeply channeled. The nodular keel which crowns the summit of each whorl, and the deeply channeled suture will distinguish this species readily.-T. \& H.

Common in a recent state on this coast, from Cape Cod, southward. Fossil in the Meiocene of Maryland, and in the Post-Pleiocene of North and South Carolina. Only small specimens have as yet been discovered in the Carolina beds.

Plate XI. Fig. 3, Natural size.

Locality. Simmons'; Wadmalaw Sound.

Museum, College of Charleston; Cabinet F. S. H.

P Y R U L A. - L A M.

PYRULA PYRUM. - L. R. Gíbes.

Plate XI. Fig. 4.

Bulla pyrum, Dill, Cat., p. 485.

Buccinis ampullaceis tenuibus, Lister, Conch., t. 877.

Pyrula spirata, Lam., An. sans Vert., Vol. 9, p. 512.

Fulgur pyruloides, Say, Amn. Conch., pl. 19.

Fulgur pyruloides, Say, Conch. United States, ed. Binney, p. 80.

Pyrula pyruloides, Ravenel, Cat. Coll. Shells, p. 15.

Pyrula spirata, Reeve, Conch. Icon., pl. 8, fig. 27.

Pyrula spirata, De Kay, Zool. New-York, Art. Mollusca, p. 142, pl. viii, figs. 180, 181.

Fulgur pyrum, Con., Pro. Acad. Nat. Sci., Vol. 6, p. 319.

Fulgur pyruloides, Say, Jour. Acad. Nat. Sci., Vol. 2, p. 237.

Pyrula pyrum, L. R. Gibbes, Tuomey's Geol. So. Ca., appendix, p. xx.

Cassidulus pyrum, Tuomey \& Holmes, Pleiocene Foss. So. Ca., p. 148, pl. xxx, fig. 2.

Description. Shell pear-shaped, thick, spirally striated, flattened above, unarmed; striæ alternately larger; suture canaliculate; spire short, exserted.

Large specimens of this shell common on the southern coast; we have found only one specimen in the Post-Pleiocene of South-Carolina.

Plate XI. Fig. 4, Natural size.

Locality. Simmons'.

Museum, College of Charleston; Cabinet F. S. H. 


\author{
FUSUS.-LaMk. \\ FUSUS CINEREUS. - SAY \\ Plate XI. Fig. 5.
}

Fusus cinereus, Say, Jour. Acad. Nat. Sci., Vol. 2, p. 236.

Fusus cinereus, Say, Amn. Conch. iii, pl. 29.

Fusus cinereus, Say, Conch. U. S., ed. Binney, pp. 79, 184.

Fusus cinereus, Conrad, Foss. Shells Tert. Form., p. 19, tab. 4, fig. 3.

Fusus cinereus, Ravenel, Cat. Coll. Shells, p. 14.

Fusus cinereus, De Kay, Zool. New-York, Art. Mollusca, p. 145, pl. viii, figs. 184, A. B. Fusus cinereus, L. R. Gibbes, Tuomey's Geol. So. Ca., appendix, p. xx.

Buccinum plicosum, Gould, Invert. Mass., p. 303, fig. 213.

Buccinum plicosum, Stimp., Shells of New-England, p. 46.

Colus cinereus, Tuomey \& Holmes, Pleiocene Foss. So. Ca., p. 150, pl. xxx, fig. 6.

Description. Shell fusiform, cancellate, transversely costate; costæ robust; revolving lines filiform, irregular, alternately smaller; labrum acute, crenated within, and alternating with the raised lines; beak short, obtuse.-T. \& $H$.

Common on the shores of the Atlantic States. Fossil in the Pleiocene of South-Carolina, and in the Meiocene of Virginia.

Plate XI. Fig. 5.

Locality. Simmons'.

Museum, College of Charleston; Cabinet F. S. H.

F USUS MIN OR.-(New Species.)

Phate XI. Figs. 6, 6a.

Description. Shell minute, fusiform, costate, striate; spire conical, elevated, smooth and polished near the apex; costæ prominent, smooth, round; sutures impressed; striæ distinct between the ribs; base transversely striated, not costated.

Plate XI. Fig. 6, Shell, natural size.

“ 6a, Magnified vierv.

Locality. Simmons'.

Museum, College of Charleston; Cabinet F. S. H. 


\section{FUSUS CQONUS.- (New Species.) \\ Plate XI. Figs. $7,7 a, 8,8 a$.}

Description. Shell conical, costate, striate; costæ, nodulous below the sutures, straight; striæ four on the middle whorls, the upper deeply impressed across the ribs, the intervening are faint; the spire is smooth and polished near the apex; base without ribs, but deeply impressed with transverse, waved, striæ; the whorls are flattened; sutures distinct; aperture semilunar; beaks short, obtuse.

Plate XI. Fig. 7, Natural size.

" 7a, Magnified vien.

" 8 , Variety of the same.

" 8a, Magnified.

Locality. John's Island.

Museum, College of Charleston.

\section{FUSUS FILIFORMIS.- (New Species.) \\ Plate XI. Fig. 9.}

Description. Shell fusiform, costate, transversely striate; costæ, smooth, somewhat nodulous at the periphery of the middle whorls; the third whorl cancellate; apex smooth ; base without ribs; striæ transverse, numerous, slightly waved, filiform.

In general outline this little shell resembles the young of F. cinereous, Say, but the smooth ribs, nodulous and angulated periphery of the middle whorls, and beautiful filiform striæ, readily distinguish it from that species.

Plate XI. Fig. 9, Shell natural size.

" 9 a, Magnified vien of same.

Locality. Simmons'.

Museum, College of Charlestom; Cabinet F. S. H.

FUSUS BULLATA.-(New Species.)

Plate XI. Figs. 10, $10 a$.

Description. Shell sub-oval, ventricose, costate, spirally grooved, tuberculated; spire short, turreted, smooth at apex ; aperture large, terminating in a short recurved canal; outer 18 
lip acute, undulated; the deep spiral grooves across the ribs of the middle-whorls give the shell a tuberculated character; the ribs do not extend below the middle of the bodywhorl; aperture semilunar; beak short, slightly recurved; canal wide.

Plate XI. Fig. 10, Shell, natural size.

10a, Magnified vien.

Locality. Simmons'.

Museum, College of Charleston; Cabinet F. S. H.

\section{FUSUS RUDIS.- (New Species.)}

Plate XI. Figs. 11, $11 a$

Description. Shell minute, costate; whorls angular, spirally grooved, and with about ten prominent and widely separated longitudinal ribs, which are widest at the periphery of the whorl, and gradually contracting above and below. The spiral grooves, which are interrupted by the ribs, are sufficiently characteristic of this little shell.

Plate XI. Fig. 11, Natural size.

" 11 a, Magnified.

Locality. Simmons'.

Museum, College of Charleston; Cabinet F. S. H.

T E R E B R A. - L A M.

TEREBRA DISLOCATA.DDE KAY.

Plate XI. Fig. 12.

Ceritheum dislocatum, Say, Jour. Acad. Nat. Sci., Vol. 2, p. 235.

Ceritheum dislocatum, Say, Conch. United States, ed. Binney, p. 79.

Ceritheum dislocatum, Ravenel, Cat. Coll. Shells, p. 14.

Terebra dislocata, De Kay, Zool. New-York, Art. Mollusca, p. 152.

Terebra dislocata, L. R. Gibbes, Tuomey's Geol. So. Ca., appendix, p. xx.

Acus dislocatum, Tuomey \& Holmes, Pleiocene Foss. So. Ca., p. 125, pl. xxvi, fig. 16. Terebra Carolinensis, Con., Sill. Jour., Vol. 4, p. 345.

Description. Shell subulate, attenuated; whorls with numerous minute revolving impressed lines, and prominent transverse ribs; near the summit of each whorl the 
transverse ribs are dislocated by a revolving line deeply impressed, which divides them into two series, the superior being shorter and thicker than the inferior.-T. \& $H$.

Recent on this coast, from Maryland to Florida; fossil in the Pleiocene of South-CaroIina and Meiocerie of Virginia.

Plate XI. Fig. 12, Natural size.

Museum, College of Charleston; Cabinet F. S. H.

BUCCINUM.-LINN.

BUCCINUM OBSOLETUM.-ADAMS

Plate XII. Fig. 1.

Nassa obsoleta, Say, Jour. Acad. Nat. Sci., Vol. 2, p. 232.

Nassa obsoleta, Say, Conch. U. S., ed. Binney, p. 77.

Buccinum Nov.-Eboracensis, Wood, Index Suppt., pl. 4, fig. 26.

Buccinum oliviforme, Kiener, Inconog., pl. 25, fig. 99.

Nassa obsoletum, Ravenel, Cat. Coll. Shells, p. 17.

Buccinum obsoletum, Adams, Boston Jour. Nat. Hist., Vol. 2, p. 267.

Buccinum obsoletum, Gould, Invert Mass, p. 308, fig. 210.

Buccinum obsoletum, De Kay, Zool. New-York, Art. Moll., p. 133, pl. viii, figs. 163, 164. Nassa obsoleta, L. R. Gibbes, Tuomey's Geol. So. Ca., appendix, p. xx.

Nassa obsoleta, Stimpson, Shells of New-England, p. 45.

Tritia obsoleta, H. \& A. Adams, Gen. Moll., Vol. 1, p. 122.

Buccinum obsoletum, Tuomey \& Holmes, Pleiocene Foss. So. Ca., p. 135, pl. xviii, fig. 5.

Description. Shell ovate, surface covered with a net-work of lines which gives it a granulated appearance; spire shorter than the body; labrum with a few elevated lines which are interrupted, and do not extend to the margin of the lip; lip simple and sharp; pillar covered with a broad callus. $-T$. \& $H$.

This is a most abundant shell along the whole coast of the Atlantic shore, and is found fossil in the Post-Pleiocene in great numbers. We have obtained it also from the Pleiocene beds of South-Carolina.

Plate XII. Fig. 1, Natural size.

Locality. Simmons'.

Museum, College of Charleston; Cabinet F. S. H. 


\title{
BUCCINUM TRIVITTATUM.-ADAM.
}

Plate XII. Fig. 2.

Nassa trivittata, Say, Jour. Acad. Nat. Sci., Vol. 2, p. 231.

Nassa trivittata, Say, Conch. U. S., ed. Binney, p. 77.

Nassa trivittata, Ravenel, Cat. Coll. Shells, p. 17.

Buccinum trivittatum, Adams, Boston Jour. Nat. Hist., Vol. 2, p. 265.

Buccinum trivittatum, Gould, Invert. of Mass., p. 309.

Buccinum trivittatum, De Kay, Zool. New-York, Art. Mollusca, p. 132, pl. viii, fig. 165. Nassa trivittata, L. R. Gibbes, Tuomey's Geol. So. Ca., appendix, p. xx.

Nassa trivittata, Stimpson, Shells of New-England, p. 45.

Buccinum trivittata, Tuomey \& Holmes, Pleiocene Foss. So. Ca., p. 135, pl. xxviii, fig. 4. Tritia trivittata, H. \& A. Adams, Gen. Mollusca, p. 122.

Description. Shell ovate-conic, cancellate; the surface presenting a net-work of decussating lines; lip with two or three teeth or saised lines within; apex acute.

This species, like B. vIBEX, when found on the north-eastern shores of the United States, has usually a chalky aspect, and we have no doubt is from the fossil sub-marine beds of the Post-Pleiocene; in advancing southwards it is more abundant, and living specimens can be had in quantity on the southern coast.- $T$. \& $H$.

It is not uncommon in the Pleiocene beds of South-Carolina, but abundant in the Post-Pleiocene.

Plate XII. Fig. 2, Natural size.

Localtty. Simmons'.

Museum, College of Charleston; Cabinet F. S. H.

\author{
BUCCINUM ACUTUM.-DE KAY. \\ Plate XII. Fig. 3.
}

Nassa acuta, Say, Jour. Acad. Nat. Sci., Vol. 2, p. 234.

Nassa acuta, Say, Amn. Conch. vi; pl. 5, fig. 3.

Nassæ acute, Say, Conch. U. S., ed. Binney, pp. 78, 216, pl. 57, fig. 3.

Buccinum acutum, De Kay, Zool. New-York, Art. Mollusca, p. 434.

Description. Shell conic-acute, whitish, cancellated so as to appear granulated; granules prominent, somewhat transverse, inequidistant, the transverse grooves being more profound and dilated than the spiral ones, which are six in number; spire longer than body- 
whorl, slender towards the tip, acute ; suture impressed, but not profoundly; beak distin guished by a depression from the body whorl, and slightly reflected; labrum incrassated, and with elevated lines upon the fauces, which do not attain the edge of the lip.-Say.

This species is readily distinguished by the incrassated outer lip.

It is very abundant in the Post-Pleiocene beds, and is recent on the Carolina and Georgia shores.

Plate XII. FIg. 3.

Locality. Simmons'.

Museum, College of Charleston; Cabinet F. S. H.

COLUMBELLA.-LAM.

COLUM BELLA AVARA.-SAY.

PLATE XII. FIG. 4.

Columbella avara, Say, Jour. Acad. Nat. Sci., Vol. 2, p. 230.

Columbella avara, Ravenel, Cat. Coll, Shells, p. 17.

Columbella avara, L. R. Gibbes, Tuomey's Geol. So. Ca., appendix, p. xx.

Columbella avara, Adams, Boston Jour. Nat. Hist., Vol. 2, p. 363.

Columbella avara, Gould, Invert. Mass., p. 313, fig. 197.

Columbella avara, DeKay, Zool. New-York, Art. Mollusca, p. 139, pl. viii, fig. 179.

Columbella avara, Stimpson, Shells of New-England, p. 48.

Columbella avara, Tuomey \& Holmes, Pleiocene Foss. So. Ca., p. 139, pl. xxviii, fig. 12.

Astyris avara, H. \& A. Adams, Gen. Mollusca, p. 187.

Description. Shell small, elongated-ovate; spire pointed, elevated; whorls with spiral impressed lines, and transverse elevated ribs; ribs on body-whorl terminate about the middle; spiral lines on the base distinct; labrum denticulated within; columellar lip with a distinct plate crenated on sub-margin; suture distinct; aperture about one-third the length of the shell.

This is an abundant species in the Post-Pleiocene beds, and common in a recent state on the Atlantic sea-shores, from Massachusetts southward.

Plate XII. Fig. 4, Natural size.

Locality. Simmons'.

Museum, College of Charleston; Cabinet F. S. H. 
C OL UMBELLA ORNATA.-RAVENEL.

Plate XII. Figs. 6, $6 a$.

Columbella ornata, Ravenel, Proc. Elliott Society, Vol. 1, p. 281.

Description. "Shell small, dirty white, ovate conic; wherls six or seven-in mature species seven can be distinguished-nearly flat, with longitudinal ribs extending almost to the apex; revolving lines interrupted at the ribs, except near the base, where the ribs become obsolete, and the revolving lines are uninterrupted and more decided than elsewhere; suture distinct, with the revolving line next below it more deeply impressed than the others; aperture nearly half the length of the shell, narrow, with a rather deep sinus at its posterior angle, ending in a short canal in front; outer lip thickened and smooth on the outside, being free from the ribs and lines of the whorls, within strongly toothed; pillar covered with smooth callus, the outer edge of which is elevated and sharp; length one-fifth inch." -E. Ravenel.

The numerous distinct longitudinal ribs readily distinguish this beautiful little species; it is the most abundant of all the univalves of the Post-Pleiocene beds in SouthCarolina.

Plate XII. FIG. 6, Natural size.

" 6a, Magnified.

Locality. Simmons'; Cainhoy; Waccamaw.

Museum, College of Charleston; Cabinets Dr. Ravenel and F. S. H.

C OLU M B L LA L UNATA.-L. R. GiввES.

Plate XII. Figs. 5, 5a.

Nassa lunata, Say, Jour. Acad. Nat. Sci., Vol. 5, p. 213.

Buccinum lunatum, Adams, Boston Jour. Nat. Hist., Vol. 2, p. 266.

Buccinum lunatum, Gould, Invert. Mass., p. 312, fig 196.

Buccinum lunatum, De Kay, Zool. New-York, Art. Mollusca, p. 131, pl. vii, fig. 162.

Columbella lunata, L. R. Gibbes, Tuomey's Geol. So. Ca., appendix, p. xx.

Columbella lunata, Stimpson, Shells of New-England, p. 48.

Nassa lunata, Say, Conch. United States, ed. Binney, p. 122.

Columbella spirantha, Ravenel, Proc. Elliott Society, Vol. 1, p. 281.

Description. Shell about six volutions; whorls with two revolving lines of dilated, 
sublunate, whitish spots and sometimes a third at the base; suture not deeply impressed; labrum dentate on the inner sub-margin, the superior teeth more prominent; labrum with the plate not thickened.

This is a common but variable shell, from Cape Cod southward. In the Post-Pleiocene it is often found with the spots well preserved.

Professor Adams, in his "Observations on the Marine Shells of Massachusetts," remarks : "The coloring in this species varies much in different individuals. Some are of a uniform, very deep brownish-red, and others are of a paler shade of the same color; but the arrangement of colors described in the Journal of the Academy (by Say) is a type of which most of the varieties are modifications. The sub-lunate whitish spots are so much enlarged as to constitute the ground color of the shell, being separated only by narrow, undulate longitudinal lines of brown, while the revolving stripes of brown which usually separate them into two or three series are wanting."

Plate XII. Fig. 5, Natural size.

" 5a, Magnified.

Locality. Simmons'; Stono River; Cainhoy.

Museum, College of Charleston; Cabinet F. S. H.

\section{STREPHONA.-BROWNE. (1756.)}

OLIVA.-LAM. (1801.)

STREPHONA LITERATA.-TUOMEY \& HOLME

PLATE XII. Fig. 7.

Oliva literata, Lam., Anim. sans Vert., Vol. 10, p. 614.

Oliva literata, Say, Amn. Conch., pl. 3.

Oliva literata, Say, Conch. United States, ed. Binney, p. 152, pl. 3.

Oliva literata, Ravenel, Cat. Coll. Shells, p. 19.

Oliva literata, L. R. Gibbes, Tuomey's Geol. So. Ca., appendix, p. xxi.

Oliva literata, De Kay, Zool. New-York, Art. Mollusca, p. 152, pl. 7, fig. 157.

Strephona literata, Tuomey \& Holmes, Pleiocene Foss. So. Ca., p. 140, pl. xxviii, fig. 13.

Utriculina literata, H. \& A. Adams, Gen. Mollusca, Vol. 1, p. 141.

Description. Shell cylindrical, thick, smooth; spire exserted, acute; whorls angular, carinated at the superior margins ; suture deeply grooved; labrum acute, simple, smooth; labium sometimes with many oblique folds; aperture linear, incised above, emarginate 
below; color yellowish-white ground, with rufous, angulated lines, and zigzag marks upon the surface, and revolving bands of light color.

This is a common shell in the Post-Pleiocene, and many specimens retain their colors and polish. The folds upon the inner lip are of an inconsistent character. We find them more or less developed in different specimens; some are perfectly smooth and simple on the columellar, as on the labrum.

Plate XII. Fig. 7, Natural size.

Locality. Simmons'.

Museum, College of Charleston; Cabinet F. S. H.

\section{OLIVA.-LAM.}

OLIVA M U T I C A. - S S Y .

Plate XiI. Fig. 8.

Oliva mutica, Say, Jour. Acad. Nat. Sci., Vol. 2, p. 228.

Oliva mutica, Ravenel, Cat. Coll. Shells, p. 19.

Oliva mutica, De Kay, Zool. New-York, Art. Mollusca, p. 152.

Oliva mutica, L. R. Gibbes, Tuomey's Geol. So. Ca., appendix, p. xxi.

Dactylidia mutica, H. \& A. Adams, Gen. Mollusca, Vol. 1, p. 146.

Oliva mutica, Say, Conch. U. S., ed. Binney, p. 75.

Description. Shell sub-oval, white or yellowish-white; body-whorl with about three revolving, maculated bands of pale rufcus, of which the superior one is continued upon the spire, the intermediate one is dilated, so as to be sometimes confluent with the inferior one, which is narrowest; spire short; suture very narrow; columella destitute of striæ.-Say.

This shell, though abundant in the Post-Pleiocene beds, seldom retains the colored markings upon the surface. It is common in the recent state on the southern coast.

Plate XII. Fig. 8, Natural size.

Locality. Simmons'.

Museum, College of Charleston; Cabinet F. S. H. 


\section{PLEUROTOMA CERINUM.-KURTZ \& STIPSON.}

Plate XII. Figs. 9, $9 a$.

Pleurotoma cerinum, Kurtz \& Stimpson, Bost. Proc. Nat. Hist., Oct., 1851.

Pleurotoma cerinum, Stimpson, Shells of New-England, p. 49, pl. ii, fig. 2.

Description. Shell small, fusiform, turreted, with about ten longitudinal folds, and numerous transverse striæ; aperture oblong; labrum simple.

This shell has been found as far north as New-Bedford harbor. It is common on the Carolina coast, and abundant in the Post-Pleiocene beds.

Plate XII. Fig. 9, Natural size.

“ $9 a$, Magnified.

Locality. Simmons'; Cainhoy; Waccamaw.

Museum, College of Charleston; Cabinet F. S. H.

\section{VOLUTOMITRA.-GRAY.}

VOLUTOMITRA WA NDOENSIS.-(New Species.)

Plate XII. Figs. 10, 10a.

Description. Shell small, sub-fusiform, ventricose; spire much longer than the aperture, papillary; whorls flattened, impressed with numerous transverse dotted grooves which become obsolete below the sutures; sutures distinct; aperture ear-shaped, contracted posteriorly; labrum thin, simple, arcuated; columellar with three oblique plaits.

We are indebted to Dr. Edward Ravenel of St. Thomas, Cooper River, for this specimen, which he discovered in the Post-Pleiocene marl of Wando river. We have named it after this beautiful stream.

Only one specimen yet found.

Plate XII. Fig. 10, Natural size.

“ 10a, Magnified. 
P O R C E L L A N A. - A D A M . (1 757 .)

MARGINELLA.-LAM. (1801.)

PORGELLA NA LIM $A$ T U LA. - CON.

Plate XII. Fig. 12.

Marginella limatula, Con., Jour. Acad. Nat. Sci., Vol. 7, p. 140.

Marginella limatula, d' Orbigny, Prodrome de Paléontologie, Vol. 3, p. 51.

Porcellana limatula, Con., Proc. Acad. Nat. Sci., Vol. 7, p. 31.

Porcellana limatula, Tuomey \& Holmes, Pleiocene Foss. So. Ca., p. 130, pl. xxvii, figs. 10, 11.

Description. Shell ovate, polished; spire very short; labrum denticulated on the inner margin; margin swelling in the centre; aperture contracted above; columellar with four oblique elevated plaits.-T. \& $H$.

This is a common shell in the Post-Pleiocene beds of South-Carolina; it differs from the Pleiocene forms in having a more elevated spire; the columellar has sometimes but three plaits, though four is not uncommon.

Plate XII. Fig. 12, Natural size.

Locality. Simmons'; John's Island.

Museum, College of Charleston; Cabinet F. S. H.

\section{VOLVARIA.-LAM.}

VOLVARIA CA N LIGULATA.-SAY.

Plate XII. Figs. 11, $11 a$.

Volvaria canaliculata, Say, Jour. Acad. Nat. Sci., Vol. 5, p. 211.

Volvaria canaliculata, Say, Conch. U. S., ed. Binney, p. 121.

Bullina canaliculata, Say, Amn. Conch., pl. 39.

Bullina canaliculata, Say, Conch. U. S., ed. Binney, p. 193.

Volvaria canaliculata, Ravenel, Cat. Coll. Shells, p. 18.

Bulla canaliculata, Gould, Invert. Mass., p. 166, fig. 97.

Bulla obstricta, Gould, Invert. Mass., p. 167, fig. 96.

Bulla canaliculata, De Kay, Zool. New-York, Art. Mollusca, p. 19, pl. xxv, fig. 328. 
Bulla canaliculata, L. R. Gibbes, Tuomey's Geol. So. Ca., appendix, p. xx.

Bulla canaliculata, Stimpson, Shells of New-England, p. 50.

Tornatina cylindrica, Emmons, North-Carolina Geol. Survey, 1858, p. 272.

Description. Shell nearly cylindrical, white, with faint lines of growth, or obsolete wrinkles; spire slightly elevated, mammillated at apex; volutions about five, summit of each with a shallow obtuse groove; aperture elongated, narrowed above; labrum thin, arcuated, inner lip with a thin plate of enamel, and an oblique fold near the base; base widely and regularly rounded.

This shell is recent upon the coast from Massachusetts southward, and very abundant in the Post-Pleiocene; from one locality we have collected several thousand specimens. Dr. Gould's obstricta is to our mind only a variety of CANALicUlata, the elevated spire is by no means uncommon.

Plate XII. Fig. 11, Natural size.

" 11a, Magnified.

Locality. Simmons'; John's Island.

Museum, College of Charleston; Cabinet F. S. H.

\section{VOLVA.-BoLton.}

VOLVA ACICULARIS.-H. \& A. ADAMS.

Plate XiI. Fig. 13.

Ovula acicularis, Lam., Wood's Index, pl. xviii, fig. 7 .

Ovula acicularis, Ravenel, Cat. Coll. Shells, p. 18.

Ovula acicularis, L. R. Gibbes, Tuomey's Geol. So. Ca., appendix, p. xxi.

Volva acicularis, H. \& A. Adams, Gen. Mollusca, Vol. 1, p. 272.

Description. Shell fusiform, ventricose, smooth, convolute, extremities prolonged into channeled beaks; labrum thickened the entire length; columellar smooth, but with a thickened ridge or longitudinal fold, which is most prominent below the inflated part of the whorl ; aperture semi-lunar.

Plate XII. Fig. 13.

Locality. Simmons'; Charleston.

Museum, College of Charleston; Cabinet F. S. H. 


\author{
NATICA.-LAM. \\ NATICA DUPLICATA. - SAY. \\ Plate XII. Fig. 14.
}

Natica duplicata, Say, Jour. Acad. Nat. Sci., Vol. 2, p. 247.

Natica duplicata, Gonld, Invert. Mass., p. 236, fig. 163.

Natica duplicata, Ravenel, Cat. Coll. Shells, p. 12.

Natica duplicata, De Kay, Zool. New York, Art. Mollusca, p. 12L, pl. vii, fig. 147.

Natica duplicata, L. R. Gibbes, Tuomey's Geol. So Ca., appendix, p. xx.

Natica duplicata, Stimpson, Shells of New-England, p. 43.

Natica duplicata, Tuomey \& Holmes, Pleiocene Foss. So. Ca., p. 114, pl. xxv, fig. 16.

Natica duplicata, Say, Conch. U. S., ed. Binney, p. 85.

Lunatia duplicata, H. \& A. Adams, Gen. Moll., Vol. 1, p. 207.

Description. Shell solid, conical-ovate; umbilicus irregular, deeply grooved, and partially or entirely covered with a callus; aperture ovate, oblique.

This is an abundant species, but variable in shape; in some specimens the spire is more elevated than in others. In a recent state it is common along the Atlantic shores of the United States, south of Nantucket.-T. \& $H$.

Plate XII. F1g. 14, Natural size.

Locality. Simmons'.

Museum, College of Charleston; Cabinet F. S. H.

\title{
NATICA PUSILLA.-SAY. \\ Plate XII. Figs. 15, $15 a$.
}

Natica pusilla, Say, Jour. Acad. Nat. Sci., Vol. 2, p. 257.

Natica pusilla, Gould, Invert Mass., p. 237, fig. 166.

Natica pusilla, De Kay, Zool. New-York, Art. Mollusca, p. 123, pl. vii, fig. 145.

Natica pusilla, L. R. Gibbes, Tuomey's Geol. So. Ca., appendix, p. xx.

Natica pusilla, Stimpson, Shells of New-England, p. 43.

Lunatia pusilla, H. \& A. Adams, Gen. of Mollusca, Vol. 1, p. 207.

Natica pusilla, Say, Conch. United States, ed. Binney, p. 87.

Description. Shell small, about half inch in length, sub-oval, marked with longitudinal 
zigzag lines ; sometimes white, without lines; umbillicus nearly closed by lateral pressure of callus, which is white. The fossil specimens are nearly all white, and the shell thick and strong.

It is recent upon the coast from Massachusetts southward.

P.Late XII. Fig. 15, Natural size.

“ 15 a, Magnified vien.

Locality. Simmons'.

Museum, College of Charleston; Cabinet F. S. H.

\author{
CATINUS.-KLEIN. \\ CATINUS PERSPEUTIVUS.-H. \& A. ADAMs. \\ Pi,ate Xil. Fig. 16.
}

Sigaretus perspectivus, Say, Amn. Conch., pl. 25.

Sigaretus perspectivus, Say, Conch. U. S., ed. Binney, pp. 175 and 205.

Cryptostoma perspectiva, Say, Amn. Conch., iii, pl. 25.

Cryptostoma perspectiva, Say, Conch. U. S., ed. Binney, pp. 175 and 205.

Calyptostoma perspectiva, De Kay, Zool. New-York, Art. Moll., p. 153, pl. vii, fig. 156.

Sigaretus perspectivus, Ravenel, Cat. Coll. Shells, p. 12.

Sigaretus perspectivus, L. R. Gibbes, Tuomey's Geol. So. Ca., appendix, p. xx.

Catinus perspectivus, H. \& A. Adams, Gen. Mollusca, Vol. 1, p. 212.

Description. Shell oval, very much depressed, but little convex, with numerous transverse, slightly undulated, sub-equidistant, impressed lines and longitudinal wrinkles; transverse lines obsolete beneath; spire not at all prominent, only a little convex; volutions about three; suture a simple, impressed line; within, the slightly elevated line is more or less obvious, not reaching the margin of the labrum; revolution of the whorls visible almost to the summit.

This shell is recent from the coast of New-Jersey southward, and abundant on the coast of South-Carolina.

Plate XII. Fig. 16, Nutural size.

Locality. Simmons'.

Museum, College of Charleston; Cabinet F. S. H. 


\section{TURBONILLA.-Risso.}

This genus comprises a great number of small and extremely beautiful shells which have tne whorls longitudinally ribbed or cancellated, and the inner lip simple and toothless.H. \& A. Adams.

TURBONILLA SPEIRA

Plate XIII. Fig. 1, 1a

Chemnitzia speira, Ravenel, Proc. Elliott Society Nat. Hist., Vol. 1, p. 280. 1850

Description. "Shell turreted, very slender and pointed, glossy white; whorls ten, nearly flat, reticulated with numerous ribs and interrupted revolving lines; suture well defined, with a distinct, impressed, revolving line a little below it, leaving a raised space like a crimped fillet, wrapped around the shell; aperture about a sixth the length of the shell, ovate, with the posterior angle sharp."-E. Ravenel.

Our specimen, from which the figure is drawn, has the apex broken off.

Plate XIII. Fig. 1, Natural size.

“ 1 a, Magnified.

Localtity. Cainhoy; Simmons'; Wadmalaw.

Museum, College of Charleston; Cabinets Dr. Ravenel and F. S. H.

TURBONILLA EXARATA.

Plate XHI. Figs. 2, 2a, $2 b$.

Pasithea exarata, H. C. Lea, Trans. Phil. So. Phila., Vol. ix, p. 25.

Pasithea exarata, Lea, New Foss. Shells, Ter. of Virginia, p. 25, pl. 35, fig. 44.

Chemnitzia exarata, d'Orb., Prod. de Paléontologie, Vol. 3, p. 33.

Description. Shell subulate accuminate, thick, imperforate, shining, costate; spire attenuate, mammillate, smooth at apex; sutures deep, excavated; whorls fifteen, flattened, with numerous flat, obliquely longitudinal ribs ; last whorl angulate ; base smooth, polished; mouth small, sub-quadrate, somewhat effuse.-H. C. Lea.

The above is Mr. Lea's description, to which we may be permitted to add what to us seems a very important character: grooves between the ribs smooth and deep, not extending quite to the sutures. 
This is a very abundant shell in the Post-Pleiocene of South-Carolina. Mr. Lea's specimen was obtained by Professor Tuomey from the Meiocene of Virginia. It is also living on the Southern coast.

$$
\begin{aligned}
& \text { Plate XIII. FIG. 2, Shell, natural size. } \\
& \text { " } 2 a \text {, Magnified view of same. } \\
& \text { " 2b, Magnified ribs and groove. }
\end{aligned}
$$

Locality. Simmons'. Museum, College of Charleston; Cabinet F. S. H.

\author{
TURBONILLA NIVEA.-H. \& A. ADAMS, \\ Plate Xili. Figs. $3,3 a, 3 b$
}

Chemnitzia nivea, Stimpson, Pro. Boston N. H. Society, Vol. 4, p. 114.

Chemnitzia nivea, Stimpson, Shells of New-England, p. 40.

Turbonilla nivea, H. \& A. Adaris, Gen. Mollusca, Vol. 1, p. 231.

Description. This shell differs from T. exarata in having the grooves and ribs straight and not obliquely longitudinal.

Mr. Stimpson dredged it at the mouth of the Bay of Fundy in fifty fathoms; it is living on the Carolina and Georgia sea shores, and very abundant as a fossil in the Post-Pleiocene beds.

Plate XIII. Fig. 3, Natural size.

" 3a, Magnified view.

" $3 b$, Ribs and growe magnified.

Locality. John's Island; Cainhoy; Simmons'.

Museum, College of Charleston.

TURBONILIA INTERRUPTA.-H.\&A. ADAMS

Plate XIII. Figs, $4,4 a, 4 b$.

Turritella interrupta, Totten, Silliman's Jour. Sci., Vol. xxviii, p. 352, fig. 7.

Turritella interrupta, C. B. Adams, Boston Jour. Nat. Hist., Vol. ii, p. 275. 
Chemnitzia interrupta, Gould, Invert. of Mass., p. 268, fig. 173.

Chemnitzia interrupta, Stimpson, Boston So. Nat. Hist., Proceed., Vol. 4, p. 16.

Chemnitzia interrupta, Stimpson, Shells of New-England, p. 41.

Turbonilla interrupta, H. \& A Adams, Gen. Mollusca, Vol. i, p. 231.

Description. There is only a slight difference in this shell from the two first named species, T. exarata, and T. nivea, (page 83.) Like the last named, the ribs are straight, but more numerous, and the grooves are crossed by about fourteen fine revolving lines, which are interrupted by the ribs; in some specimens the lines appear to be in pairs when seen through a lens.

Plate XIII. Fig. 4, Natural size.

“ 4a, Magnified.

"4b, Magnified rib and groove.

Locality. Simmons'.

Museum, College of Charleston; Cabinet F. S. H.

\author{
TURBONILLA CANCELLATA.-(New Species.) \\ Plate XiII. Figs. $6,6 a, 6 b$.
}

Description. The whorls of this species are more inflated than any of the foregoing; the sutures are deeper and angular, and the grooves are crossed by four lines, one equidistant from the sutures, and a pair in the middle. To the unassisted eye the shell appears beautifully cancellated.

Plate XIII. Fig. 6, Natural size.

" 6a, Magnified.

“ 6b, Magnified ribs, grooves, and revolving lines.

Locality. 'Simmons'. Museum, College of Charleston; Cabinet F. S. H. 


\section{TURBONILLA QUINQUE-STRIATA.-(New Species.) \\ Plate XIII. Fig. $5,5 a, 5 b$.}

Description. Shell same as T. nivea; but having only five revolving lines across the grooves, the superior one single and the others in pairs.

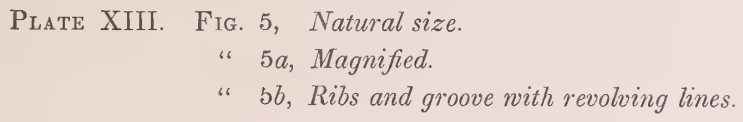

Locality. Simmons'. Museum, College of Charleston; Cabinet F. S. H.

\section{T URBONILLA L I NEATA.- (New Species.) \\ Plate XiII. Figs. $7, \tau a, 7 b$.}

Description. In this species there are four revolving lines, in two pairs, across the groove; the inferior line of each pair is wide, nearly twice that of the superior line; the ribs are also wider and more prominent; the lowest whorl profoundly ventricose.

Plate XIII. Fig. 7, Natural size.

“ 7a, Magnified.

"76, Magnified ribs, grooves, and revolving lines.

Locality. Simmons'. Museum, College of Charleston; Cabinet F. S. H

\section{TURBONILLA SUBULATA. - (New Species.) \\ Plate XIII. Figs. $8,8 a, 8 b$.}

Description. The whorls in this species are not so much inflated as in T. Lineata, (fig. 7,) but the shell more subulate; it has the same number of revolving lines, two pair, but the broad line is the superior.

Plate XiII. Fig. 8, Natural size.

" $8 a$, Magnified.

" 8b, Magnified ribs, grooves, and revolving lines.

Locality. Cainhoy, Wando River; Toogoodoo. 


\section{TURBONILLA CAROLINIANA.- (New Species.)}

Plate XIII. Figs. 9, $9 a, 9 b$.

Description. T. caroliniana differs from the foregoing in having five pairs of revolving lines.

Plate XIII. Fig. 9, Natural size.

" $9 a$, Magnified.

“ $9 b$, Magnified ribs, grooves, and revolving lines.

Locality. Cainhoy, Wando River.

Museum, College of Charleston; Cabinet F. S. H.

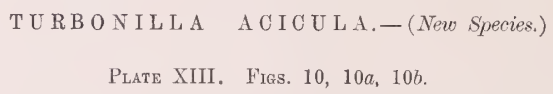

Description. This species has about eight revolving lines, and more nearly resembles, in general form, T. INTERRUPTA, (fig. 4.)

Plate XIII. Fig. 10, Natural size.

“ 10a, Magnified.

“ 10b, Magnified ribs, grooves, and revolving lines.

Localtty. Cainhoy, Wando River.

Museum, College of Charleston; Cabinet F. S. H.

\section{ODOSTOMIA.-FLEMING.}

O D OSTOMIA GRA U U A T U S.

Plate XIII. Figs. 11, 11 $a, 11 b$.

Acteon granulatus, H. C. Lea, New Ter. Fossils, p. 29, pl. 36, fig. 54.

Description. "Shell subulate, thick, sub-perforate, nodulously costate; spire elevated, obtuse, mammillate, polished at apex; sutures impressed; whorls six, convex ; ribs 
transverse, flat, regularly nodulous, a smooth one near the lower suture; last whorl rounded; base costate; perforation very small; mouth ovate, angular above, somewhat effuse; fold on the columellar large, acute. The nodules on the ribs are small, and in regular order, giving the shell a granulate and cancellate appearance. The fold on the columellar is placed about the middle, and is quite large; the mouth is rounded below, and acutely angular above. On the body-whorl the ribs are about eight in number, while there are five on those of the spire. The basal costæ are smooth and smaller."H. C. Lea.

The fossil, as figured by us; has four of the spire-ribs granulated, and one smooth. The above description of Mr. Lea's characterizes it as identical with his species from the Meiocene of Virginia; but his figure is very unlike that of the Post-Pleiocene shell.

$$
\begin{array}{r}
\text { Plate XIII. Fig. } 11, \text { Natural size. } \\
\text { " } 11 \text { a, Magnified. } \\
\text { " } 11 b \text {, Magnified costc. }
\end{array}
$$

Locality. Cainhoy, Wando River.

Museum, College of Charleston; Cabinet F. S. H.

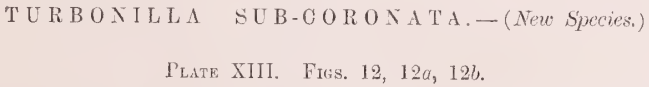

Description. Shell subulate, acuminate, thick, imperforate, costate; spire attenuate, mammillate, smooth at apex ; two first whorls striate ; five lower whorls angulate, granu late, transversely grooved, sub-coronated below the sutures; columellar with a small, almost obsolete fold; the spiral ribs of the lower whorls are seven in number, crossed by transverse revolving grooves, which gives the shell a regularly granulate appearance; the granulations of the superior rib, below and next the sutures, are large; the revolving line below the suture is more deeply impressed than the others.

Plate XIII. F1G. 12, Natural size.

“ 12a, Magnified.

" $12 b$, Granulated whorl.

Locality. Simmons'.

Museum, College of Charleston; Cabinet F. S. H. 


\title{
EULIMA.-RISSO.
}

EULIMA EBOREA.-CONRAD.

Plate XIII. Fig. 13.

Eulima eborea, Con., Pro. Acad. Nat. Sci., Vol. 3, p. 20.

Eulima conoidea, Kurtz \& Stimpson, Pro. Bost. So. Nat. Hist., Vol. 4, p. 115.

Eulima oleacea, Kurtz \& Stimpson, Pro. Bost. So. Nat. Hist., Vol. 4, p. 115.

Eulima lævigata, Emmons, North-Carolina Geol. Survey, 1858, p. 269.

Description. Shell sub-conical, smooth, milky-white, sometimes almost transparent; whorls nine to twelve; suture slightly defined; in some specimens a bluish or brown band revolves below the sutures; aperture somewhat oblique, ovate-acute.

This is a variable shell, abundant in the Post-Pleiocene of South-Carolina, and according to Mr. Conrad, found in the Meiocene of Suffolk, Virginia. It is recent on the Atlantic coast, from Buzzard's bay southward. E. conoidea, E. LAvigata and E. OLEACEA are to our mind one and the same species.

Plate XIII. Fig. 13, Natural size.

Locality. Simmons'.

Museum, College of Charleston; Cabinet F. S. H.

\section{OBELISCUS.-HumpHREY.}

\author{
OBELISCUS CRENULATUS.-(New Species.) \\ Plate Xill. Figs. 14, $14 a$.
}

Description. Shell subulate, smooth, angularly channeled at the suture, which is crenulated on the lower whorls only; columellar with three folds, the superior one large and acute, the others small; outer lip with four small teeth internally; whorls fourteen to sixteen; with two indistinct opaque revolving bands, which are sometimes obsolete.

This shell is readily distinguished from its congener, O. ARENosa, of the Pleiocene, by having only the lower edge of the suture crenulated, one more fold and tooth, and opaque revolving bands.

This species, and not O. AREnosa, is now living on the coast of South-Carolina.

Plate XIII. Fig. 14, Natural size.

" 14a, Magnified suture and crenulated whorls.

Locality. Simmons'. Museum, College of Charleston; Cabinet F. S. H. 


\section{SCALARIA CLATHRUS. - LINN.}

Plate XIV. Fig. 1.

Scalaria clathrus, var. b., Say, Amn. Conch., iii, pl. 27.

Scalaria clathrus, Ravenel, Cat. Coll. Shells, p. 13.

Scalaria clathrus, De Kay, Zool. New York, Art. Mollusca, p. 127.

Scalaria clathrus, L. R. Gibbes, Tuomey's Geol. So. Ca., appendix, p. xx.

Scalaria clathrus, Tuomey \& Holmes, Pleiocene Foss. So. Ca., p. 124, pl. xxvi, fig. 15.

Clathrus clathrus, H. \& A. Adams, Gen. Moll., Vol. 1, p. 222.

Scalaria clathrus, Say, Conch. U. S., ed. Binney, p. 179.

Description. "Shell conic, turreted, imperforate, white, immaculate; whorls from six to eleven, touching each other only by the ribs, but with a narrow interval; ribs nine to each volution; prominent, simple, a little oblique; somewhat recurved, and with a more or less obvious obtuse angle or shoulder above, near the suture; aperture oval-orbicular ; base a little angulated ; labium distinct."-Say.

Common on the Carolina coast, and in the Post-Pleiocene beds.

Plate XIV. FIg. 1, Natural size.

Locality. Simmons'; Cainhoy; Waccamaw.

Museum, College of Charleston; Cabinet F. S. H.

\section{SUALARIA ANGULATA.-SAY.}

Plate XIV. Fig. 2.

Scalaria angulata, Say, Amn. Conch., pl. '27.

Scalaria clathrus, Say, Conch. U. S., ed. Binney, p. 179.

Description. As regards this species there seems to be some doubt with Mr. Say; he calls it a variety of S. Clathrus, but to our mind it is a distinct species. The outline of the shell is very unlike that of S. CLATHuds, being more conical and shorter, and the angular, pointed ribs will always distinguish it. We have had several hundred recent specimens from the coast of South-Carolina, and are satisfied they are distinct.

Plate XIV. Fig. 2, Natural size.

Locality. Simmons'.

Museum, College of Charleston; Cabinet F. S. H. 


\section{SCALARIA LINEATA. \\ Plate XIV. Fig. 3.}

Scalaria lineata, Say, Jour. Acad. Nat. Sci., Vol. 2, p. 242.

Scalaria lineata, Say, Amn. Conch., iii, pl. 27.

Scalaria lineata, Ravenel, Cat. Coll. Shells, p. 13.

Scalaria lineata, Gould, Invert. Mass., p. 250.

Scalaria lineata, De Kay, Zool. New-York, Art. Moll., p. 126, pl. vi, fig. 125.

Scalaria lineata, L. R. Gibbes, Tuomey's Geol. So. Ca., appendix, p. xx.

Scalaria lineata, Stimpson, Shells of New-England, p. 39.

Scalaria lineata, H. \& A. Adams, Gen. Recent Mollusca, Vol. 1, p. 220.

Scalaria lineata, Say, Conch. United States, ed. Binney, pp. 83, 180.

Description. "Shell brownish, elongated, with about seven volutions; costæ robust, obtuse, little elevated, and from seventeen to nineteen on the body-whorl; body-whorl with generally a blackish, more or less, dilated line, which is nearly concealed on the volutions of the spire, by the suture; margin of the mouth robust, white, more dilated at the columellar base; body-whorl with a raised line."-Say.

Recent on the coast from Massachusetts southward.

Plate XIV. Fig. 3, Natural size.

Locality. Simmons'.

Museum, College of Charleston; Cabinet F. S. H.

\section{SCALARIA MULTISTRIATA.DSY.}

Plate XIV. Fig. 4.

Scalaria multistriata, Say, Jour. Acad. Nat. Sci., Vol. 5, p. 208.

Scalaria multistriata, Say, Amn. Conch., iii, pl. 27.

Scalaria multistriata, Ravenel, Cat. Coll. Shells, p. 13.

Scalaria multistriata, De Kay, Zool. New-York, Art. Mollusca, p. 126.

Scalaria multistriata, L. R. Gibbes, Tuomey's Geol. So. Ca., appendix, p. xx.

Scalaria multistriata, Gould, Invert. Mass., p. 251.

Scalaria multistriata, Stimpson, Shells of New-England, p. 39.

Scalaria multistriata, H. \& A. Adams, Gen. Mollusca, Vol. 1, p. 221.

Scalaria multistriata, Say, Conch. U. S., ed. Binney, pp. 119 and 180.

Description. "Shell conic, turreted, tapering to an acute apex, white, immaculate, 
imperforate; whorls about eight, in contact; costæ regular, simple, not reflected, equidistant, moderately elevated; spaces between the costæ, with numerous, approximate, equidistant, impressed lines; suture well impressed; body-whorl with about sixteen costæ."-Say.

Plate XIV. Fig. 4, Natural size.

Locality. Simmons'.

Museum, College of Charleston; Cabinet F. S. H.

\section{LITTORINA.—FERUSSAC.}

LITTORINA IRRORATA.-GRAY.

Plate XIV. Fig. 5.

Littorina irrorata, Gray, Zool. Beechey's Voy., pl. 31. fig. 1.

Turbo irroratus, Say, Jour. Acad. Nat. Sci., Vol. 2, p. 239.

Phasianella sulcata, Ravenel, Cat. Coll. Shells, p. 14.

Littorina irrorata, De Kay, Zool. New-York, Art. Mollusca, p. 106, pl. vi, fig. 112.

Littorina irrorata, L. R. Gibbes, Tuomey's Geol. So. Ca., appendix, p. xx.

Littorina irrorata, Stimpson, Shells of New-England, p. 33.

Littorina irrorata, Tuomey \& Holmes, Pleiocene Foss. So. Ca., p. 119, pl. xxvi, fig. 5.

Description. Shell thick, top-shaped; whorls, with numerous revolving, elevated, obtuse, equal lines; body-whorl very large; suture well defined; spire acute; aperture large, entire, rounded-ovate; outer edge of lip thin ; labium thick.-T. \& $H$.

This shell is rare in the Meiocene, not very common in the Post-Pleiocene, but abundant in a recent state on the salt marshes of southern estuaries, where they are seen in great numbers, clinging to the stems of the marsh reeds-Spatina glabra. Mr. Stimpson has found it as far north as Connecticut.

Plate XIV. Fig. 5, Natural size.

Locality. Simmons'; Wadmalaw; Cainhoy.

Museum, College of Charleston; Cabinet F. S. H. 


\title{
ARCHITECTONICA.-BoLTON. SOLARIUM.-LAM.
}

\author{
A R CHITECTONICA GEMMA.- (New Speeies.) \\ Plate XIV. Figs. 6, $6 a, 6 b$.
}

Description. Shell orbicular, sub-trochiform, deeply umbilicated; spire obtuse; whorls about four or five, angulated; a finely serrated carina at the periphery extends from the mouth nearly to the apex, where it becomes obsolete; aperture sub-quadrate; peristome thin, angulated above and below; umbilicus large, spiral, crenulated; base transversely marked with the lines of growth, which extend from the periphery of the body-whorl and form the crenulations on the margin of the umbilicus; suture distinct.

For this beautiful little shell we are indebted to Dr. Edm'd Ravenel, of the Grove plantation, who found it in the marl beds of Cainhoy, Wando river. Only one specimen yet obtained. The serrated carina around the pheriphery is not visible to the unassisted eye, but requires a lens of moderate power to be distinguished.

Plate XIV. Fia. 6, Natural size.

" 6a, Magnified view.

“ $6 b$, Outline of form magnified.

Locality. Cainhoy, Wando River.

Cabinet of Dr. Edm'd Ravenel.

$$
\text { ANGARIA.-BULTON. }
$$

D E L P H I N U A. - R o I S S .

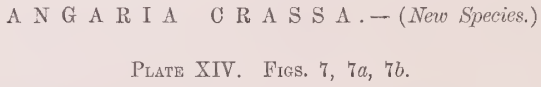

Description. Shell solid, smooth, turbinate, umbilicate; spire obtuse, discoidal; whorls three to four, ventricose, sub-angulated above; body-whorl larger than the entire spire; suture angulated, deeply impressed; aperture rounded; entire peristome thick, reflected; labrum very thick, greatest on the superior edge; umbilicus wide; spiral-margin round, smooth.

A filliform carina, produced by the flattening of the upper surface of the whorls, extends from the apex to the aperture; in many specimens it becomes obsolete near the apex, and also near the aperture.

Of thirty-four specimens, which we have collected from the marl beds of the Stono, not 
one is perfect; the lips of all of them are broken, hence the peristome, though described above as reflected, is marked as doubtful.

Since the discovery of the specimen of which our figure is a copy, we have obtained many much larger, say three-eighths of an inch in diameter.

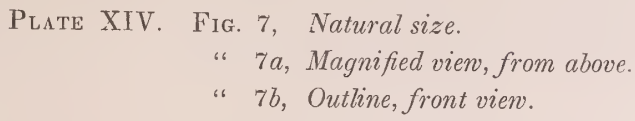

Locality. Stono beds, Simmons'; Wadmalaw

Museum, College of Charleston; Cabinet F. S. H.

\author{
ADEORBIS.-SEarLes Wood. \\ Vil: \\ ADEORBIS NAUTILIFORMIS. - (New Species.) \\ Plate Xiv. Figs. $8,8 a, 8 b$.
}

Description. Shell depressly-conical, orbicular, nautiliform, thin, deeply umbilicated ; whorls few, say two, angulated at the periphery, smooth, divided externally and regularly into segments by transverse, depressed lines of growth, which are less distinct on the spire, but profound on the base; aperture transversely oval, contracted above; peritome interrupted; umbilicus deep, simple; outer lip arcuate, thin; inner lip sinuated.

We are indebted to Dr. E. Ravenel for this interesting species, which may be readily distinguished from its congeners by the depressed, transverse, arcuated and equidistant lines, which divide the whorls into segments.

Plate XIV. Fig. 8, Natural size.

" 8 a, Magnified view, from above.

“ 8b, Magnified outline.

Locality. Cainhoy, Wando River.

Museum, College of Charleston; Cabinet Dr. Ravenel.

COCHLIOLEPIS PARASITIUUS. STRMPSON.

Plate Xiv. Fies. $9,9 a, \rho b$.

Cochliolepis parasiticus, Stimpson, Pro. Bost. So. Nat. Hist., 1857, Vol. 6, p. 307.

Description. "Shell thin, discoidal, convex above, concave and umbilicated below; 
the edge thin and sharp; whorls three in number, rapidly enlarging; surface smooth and glossy, indistinctly striated with lines of growth; lip not thickened; diameter an eighth of an inch."-Stimpson.

The shell represented in our figure, from the Post-Pleiocene, differs very little from the description of the recent shell, as given above; the fossil is thicker in substance than those which we have obtained from the coast, and those which Messrs. Stimpson and Kurtz found parasitic on Acoëtes lupina, a gigantia annelide of the Aphrodite family. It is very common in the fossil state.

Plate XIV. Fig. 9, Natural size.

“ 9a, Magnified.

" 9b, Magnified outline.

Locality. Simmons'.

Museum, College of Charleston; Cabinet F. S. H.

FISSURELLA.-BRUG.

FISSURELLA ALTERNATA.-SAX.

Plate XIV. Fig. 10.

Fissurella alternata, Say, Jour. Acad. Nat. Sci., Vol. 2, p. 224.

Fissurella alternata, Ravenel, Cat. Coll. Shells, p. 9.

Fissurella alternata, L. R. Gibbes, Tuomey's Geol. So. Ca., appendix, p. xx.

Fissurella alternata, Say, Conch. U. S., ed. Binney, p. 73.

Description. "Shell oblong-ovate, moderately thick, cinerous or dusky, with equal concentric lines, crossed by alternately larger and smaller radii, all which are equable or not dilated in any part: vertex placed nearer the smaller end; perforation oblique, oblong, and a little contracted in the middle; within white; margin simply crenate; apex with an indented transverse line at the larger end of the perforation." - Say.

Fissurella alternata is common on the coast of Carolina and Georgia.

Plate XIV. Fig. 10, Natural size.

Localtity. Simmons'; Stono River.

Museum, College of Charleston; Cabinet F. S. H. 


\author{
CRY PTA.-Нuмн. (1797.) \\ C REPIDULA.-LAM . ( 18001 .) \\ C R Y P TA FOR N I C A T.- H. A. A D A S . \\ Piate XIV. Fig. 11.
}

Patella fornicata, Linn., Syst. Nat., 1257.

Crepidula fornicata, Lam., An. sans Vert., Vol. 7, p. 641.

Crepidula fornicata, Martini, 1, pl. 13, figs. 129 and 130.

Crepidula fornicata, var., Say, Jour. Acad. Nat. Sci., Vol. 2, p. 225.

Crepidula fornicata, Con., Foss. Med. Ter. Form., pl. 45, fig. 10.

Crepidula fornicata, Say, Conch U. S., ed. Binney, p 73.

Crepidula fornicata, Ravenel, Cat. Coll. Shells, p. 9.

Crepidula fornicata, Gould, Invert. Mass., p. 158, fig. 17.

Crepidula fornicata, De Kay, Zool. New-York, Art. Mollusca, p. 157, pl.vii, figs. 152, 154

Crepidula fornicata, L. R. Gibbes, Tuomey's Geol. So. Ca., appendix, p. xx.

Crepidula fornicata, Stimpson, Shells of New-England, p. 30.

Crypta fornicata, H. \& A Adams, Gen. Mollusca, Vol. 1, p. 369.

Crypta fornicata, Tuomey \& Holmes, Pleiocene Foss. So. Ca. p. 110, pl. xxv, fig. 9.

Description. "Shell oblique-oval, convex, smooth, sometimes wrinkled with obsolete undulating longitudinal lines; apex prominent; diaphragm sub-concave, occupying half the interior of shell, the free edge waving. This is a common species in the Pleiocene beds of South-Carolina, and abundant on the sea-shores in a living state. In the marl of Goose Creek a series of united casts occupying their natural position, are common fossils."-T. \& $H$.

Plate XIV. Fig. 11, Natural size.

Locality. Simmons'.

Museum, College of Charleston; Cabinet F. S. H.

CRYPTA ACULEATA.

Plate XIV. Fig. 12.

Crepidula aculeata, Lam., Anim. sans Vert., Vol. 7, p. 642.

Crepidula aculeata, Sowerby, Gen., n. 23.

Crepidula aculeata, Ravenel, Cat. Coll. Shells, p. 9. 
Crepidula aculeata, L. R. Gibbes, Tuomey's Geol. So, Ca., appendix, p. xx. Crepipatella aculeata, H. \& A. Adams, Gen. Mollusca, Vol. 1, p. 369.

Description. Shell oval, convex, longitudinally ribbed, ribs thick, elevated wrinkled, with a series of erect spines; diaphragm sinuous, with a ridge in the middle extending from the beak to the margin; apex of shell lateral, incurved, sub-terminal.

The lateral, incurved, sub-terminal beaks, are characteristic of this genus.

Plate XIV. Fig. 12, Natural size.

Locality. John's Island, Stono River.

Museum, College of Charleston; Cabinet F. S. H.

\author{
CHITON.-LINN. \\ CIIT ON A PICULATUS. - SAY. \\ Pi.ate XiV. Figs. $13,13 a, 13 b, 13 c$.
}

Chiton apiculatus, Say, Amn. Conch., 8.

Chiton apiculatus, Say, Conch. U. S., ed. Binney, p. 231.

Chiton apiculatus, Ravenel, Cat. Coll. Shells, p. 8.

Chiton apiculatus, Gould, Invert. Mass., p. 146, fig. 20.

Chiton apiculatus, De Kay, Zool. New York, Art. Mollusca, p. 164, pl. x, figs 201, 202.

Chiton apiculatus, L. R. Gibbes, Tuomey's Geol. So. Ca., appendix, p. xx.

Chiton apiculatus, Stimpson, Shells of New-England, p. 28.

Description. "Valves eight; dorsal triangles, with series of elevated points; lateral triangles with scattered elevated points. Inhabits the coast of South-Carolina." - Say.

Only a single dorsal valve of this shell has as yet been found in the Post-Pleiocene.

Plate XIV. Fig. 13, Side vien, natural size.

" 13 a, Vien from above.

" 13b, Magnified vien of same.

" 13c, Magnified view of one series elevated points

Locality. Simmons'. Musent, College of Charleston; Cabinet F. S. H 


\section{PLANORBIS.-GUETTARD.}

\section{PLANORBIS LENTUS. - SAY}

Plate XIV. Fig. 14.

Planorbis lentus, Say, Amn. Conch., pl. 4, fig. 1.

Planorbis lentus, Ravenel, Cat. Coll. Shells, p. 11.

Planorbis lentus, Gould, Invert. Mass., p. 202, fig. 132.

Planorbis lentus, De Kay, Zool. New-York, p. 60, pl. 5, fig. 80, a. b.

Planorbis lentus, L. R. Gibbes, Tuomey's Geol. So. Ca., appendix, p. xix.

Planorbis lentus, Stimpson, Shells of New-England, p. $5 \mathrm{l}$.

Helisoma lentus, H. \& A. Adams, Gen. Mollusca, Vol. 2, p. 262.

Description. "Shell dull brownish or yellowish brown, sub-carinate above, particularly in the young shell; whorls nearly five; striate across, with five raised, sub-equidistant lines, forming grooves between them; spire concave; aperture large, embracing a large portion of the penultimate volution; labrum more acutely, but not very prominently, arquated above, its basal portion horizontally sub-rectilinear in the adult, and not extending below the level of the base." - Say

A very imperfect shell was found at Mr. Simmons'.

Plate XIV. Fig. 14, Natural size, imperfect specimen.

Locality. Simmons'. Museum, College of Charleston; Cabinet F. S. H.

MELAMPUS.-MonTFoRT.

MELAMPUS BIDENTATUS. - SAY.

Plate XIV. Figs. 15, $15 a$.

Melampus bidentatus, Say, Jour. Acad. Nat. Sci., Vol. 2, p. 245.

Auricula bidentata, Gould, Invert. Mass., p. 197, fig. 130.

Auricula bidentata, De Kay, Zool. New-York, Art. Moll., p. 57, pl. v, figs. 92.

Auricula bidentata, L. R. Gibbes, Tuomey's Geol. So. Ca., appendix, p. xix.

Melampus corneus, Stimpson, Shells of New-England, p. 51. 
Melampus bidentatus, H. \& A. Adams, Gen. Mollusca, Vol. 2, p. 243.

Melampus bidentatus, Say, Conch. United States, ed. Binney, p. 84.

Description. "Shell thin, fragile, dirty-brownish, very little elevated, obtuse; body" whorl with minute transverse wrinkles and revolving impressed striæ; labium bidentate; the superior tooth transverse, prominent, terminating at the exterior edge of the columellar; labrum with four or five elevated striæ, not attaining the edge; base not contracted."-Say.

Plate XIV. Fig. 15, Nutural size.

“ 15a, Magnified.

Locality. Simmons'.

Museum, College of Charleston; Cabinet F. S. H. 


\title{
DESCRIPTION OF VERTEBRATE FOSSILS.
}

\author{
BY Prof. JOSEPH LEIDY.
}

\author{
I N T R O D C T O R Y RE M R K S. *
}

THE interesting collection of remains of vertebrated animals, which form the subject of the following pages, with few exceptions, have been submitted to the inspection of the author, by Prof. F. S. Holmes and Capt. A. H. Bowman, U. S. A. The greater part of the fossils were obtained by these gentlemen from the shores of the Ashley river, or its vicinity, about ten miles above Charleston. The country, in the locality indicated, exhibits a base of whitish Eocene marl, containing remains of cetaceans, and of sharks, rays, and other fishes, together with fossil mollusks and zoophytes, which have formed part of the material of the valuable researches of Prof. Holmes.

Above the Eocene formation there is a stratum of Post-Pleiocene marl, about one foot in thickness, overlaid with about three feet of sand and earth mould. The Post-Pleiocene deposit contains quantities of irregular, water-worn fragments of the Eocene marl-rock from beneath, mingled with sand, blackened pebbles, water-rolled fragments of bones, and other more perfect remains of fishes, reptiles, and mammals, which belong to the PostPleiocene period, or have been derived from the underlying Eocene formation.

On the Ashley river, where the Post-Pleiocene and Eocene formations are exposed, fossils and pebbles are washed from their bed, and form part of the shingle of the shore, and here become mingled with the remains of recent indigenous and domestic animals, together with objects of human art. From these circumstances, it is sometimes difficult to determine to what particular geological formation or period, whether Eocene, PostPleiocene, or Recent, the fossils collected on the Ashley shores, are to be referred. The difficulty is especially great in regard to the remains of fishes, less so with the reptiles and cetaceans, and least so with the other mammalian fossils.

Of those vertebrate remains actually obtained in excavations of the Post-Pleiocene and Eocene formations, more confidence is felt in determining the actual age to which they belong.

* For notes on the geological formations in which the vertebrate fossils described in this paper were discovered, see Appendix to this volume.-(F. S. Holmes.) 
Both the collections submitted to the author by Prof. Holmes and Capt. Bowman, contain remains of the horse, ox, sheep, hog, and dog, which, we feel strongly persuaded, with the exception of many of those of the first mentioned genus, are of recent date, and have become intermingled with the true fossils of the Post-Pleiocene and Eocene periods on the Ashley river and its tributaries. In regard to the remains of the horse, from the facts related in the succeeding pages, we think it must be conceded that several species of this animal inhabited the country of the United States, during the Post-Pleiocene period, contemporaneously with the mastodon, the giant sloth, and the great, broad-fronted bison.

Class, MAMMALIA. Order, SOLIPEDIA.

Genus, EQUUS.-LinN.

\section{EQUUS FRATERNS. EQUUS COMPLICATUS.}

Plates XV, XVI. Figs. 2-31.

Equus major, De Kay, Zoology of New-York, pt. 1, Mammalia, 108.

Equus Americanus, Leidy, Proc. Acad. Nat. Sci., III, 262.

Equus fraternus et E. complicatus, Leidy, Proc. Acad. Nat. Sci., 1858, 11.

It appears to be quite well authenticated that the Horse, now so extensively distributed, both in a wild and domestic condition, throughout North and South America, did not inhabit these continents at the time of their discovery by Europeans. Coupling this fact with the circumstance, that in many instances fossils may become accidental occupants of earlier geological formations than those to which they actually belong, we should require strong evidence before it is admitted that species of the Horse belonged to the ancient fauna of the western world. At the present time such evidence is not only ample for the purpose, but actually indicates that more equine animals formerly lived in North America than in any other portion of the earth, so far as is known.

Remains of the Horse, discovered in Brazil, Buenos Ayres, and Chili, have been indicated by Dr. Lund," Prof. Owen, $\dagger$ M. Weddell, $\downarrow$ and M. Gervais. $\S$ These remains exhibit no well marked characters distinguishing them from corresponding portions of the skeleton of the domestic Horse, and it is uncertain whether they are referrable to one or more species.

*Ann. Sc. Nat., 2d s., XII, 319. Equus neogaeus; E. principalis.

$\dagger$ Voyage Beagle; Fossil Mammalia, 108; Catalogue Foss. Mus. Roy. Col. Surg., 236. E. curvidens.

† Voyage Bolivie, 204. E. maerognathus.

§ Hist. Chili; Zool. I, 146; Rech. Mam. Foss., 33, 35. E. Americanus; E. Devillei. 
Prof. Buckland* and Sir John Richardson $†$ have described remains of the Horse, discovered in association with those of the elephant, moose, rein-deer, and musk-ox, in the ice cliffs of Eschscholtz bay, Arctic America.

In the United States, remains of the Horse, chiefly consisting of teeth, have been noticed by Drs. Mitchell, Harlan, $\S$ and DeKay, || but these gentlemen have neither given descriptions nor figures by which to identify the specimens. Some of the latter are stated to have been found in the vicinity of Neversink Hills, New Jersey; others in the excavation for the Chesapeake and Ohio Canal, near Georgetown, District of Columbia; and some in the later Tertiary deposit on Neuse river, in the vicinity of Newbern, North Carolina. Dr. DeKay, in speaking of such remains, says: "They resemble those of the common Horse, but from their size, apparently belonged to a larger animal "" and he refers them to a species with the name of Equus major.

Dr. R. W. Gibbes has given information of the discovery of teeth of the Horse in the Pleiocene deposit of Darlington, South-Carolina ; in Richland District, of the same State; in Skidaway Island, Georgia; and on the banks of the Potomac river. He further observes that he obtained the tooth of a Horse, from Eocene marl, on the Ashley river, South-Carolina, but the researches of Prof. Holmestit indubitably indicate the specimen to have been an accidental occupant of that formation.

Specimens of isolated teeth, and a few bones of the Horse, from the Post-Pleiocene and recent deposits of this country, east of the Mississippi river, have frequently been submitted to my inspection. Many of these I have unhesitatingly pronounced to be relics of the domestic horse, though I feel persuaded that many remains of an extinct species are undistinguishable from the recent one.

Whether more than one extinct species is indicated among the numerous specimens of teeth I have had the opportunity of examining, I have been unable positively to determine, but the testimony inclines me to suspect the existence of at least two species. One of these was apparently about the size of the ordinary varieties of the domestic horse, and possessed molar teeth, not more complicated in the arrangement of their enamel than in the latter. The second species was about the size of the English dray horse, and possessed molar teeth, with the enamel much more complexly plicated than in any recent species of Equus.

These two species, for which the names heading the present chapter have been proposed, appear to have held the same relation to each other, in size and anatomical constitution, as the Equus primigenius and E. plicidens, of Europe.

The two species are, however, not always readily separated from each other, for their remains frequently exhibit such an approximation of characters, that it is often difficult to say to which they actually belong.

The specimens of molar teeth of the Horse, which I formerly attributed to the extinct

* Beechey's Voyage to the Pacific, 1831. Appendix, 595. || Zoology New-York, pt. 1, Mammalia, 108.

$†$ Zoology of the Voyage of the Herald, 1854, 17. Equus fossilis, Richardson.

‡Catalogue of Organic Remains, 1826, 7, 8. ** Proc. Amer. Assoc., 1850, 66.

$\S$ Med. and Phys. Researches, 1835, 26 7.

†† Ibidem, 68 . 
species of South America, under the name of Equus curvidens, Ow en," were obtained from a pond in a marsh of Big-bone-lick, Kentucky, together with some bones of the existing Bison, the Megatonyx, and the Mastodon. From their size, form, and condition of preservation, I am now disposed to believe they are recent remains, which subsequently became mingled with their older associates.

Among a number of teeth of the Horse in Prof. Holmes' collection, labelled as coming from the Post-Pleiocene deposit of Ashley river, there are several which from their size, construction, and condition of preservation, I feel convinced are of recent date; and these, no doubt, became mingled with the true fossils of that formation, where it is exposed on the Ashley river, in which position I personally found undoubted remains of the recent Horse and other domestic animals, and objects of human art, mingled with remains of fishes, reptiles, and mammals, washed by the river from the banks, composed of Eocene and Post-Pleiocene deposits.

Teeth of an extinct species of Horse, however, undoubtedly belong, as true fossils, to the Post-Pleiocene formations in the vicinity of Charleston. These are usually hard in texture, stained brown or black, from the infiltration of oxide of iron, sometimes well preserved, but more frequently in a fragmentary condition and water-worn. Generally they are not larger than the teeth of the more ordinary varieties of the domestic horse, and sometimes are quite as simple in the plication of their enamel, but usually are more complex, and sometimes exceedingly so.

Figures 19-22, Plate XVI, represent four inferior molar teeth of the extinct Horse, which were obtained by Prof. Holmes from an excavation of the Post-Pleiocene deposit of Ashley river. The pair represented in figures 19,21 , exhibit a greater degree of plication in the enamel than is usual in any of the lower molars of the Horse, whether recent or extinct; but the others present nothing peculiar. They range from two to three inches in length, thirteen to fourteen lines in breadth, and seven to eight lines in width.

Figure 8, Plate XV, represents a first superior molar tooth, neither larger nor more complex in structure than the corresponding tooth of the recent Horse. This specimen, which is dense and jet black in color, was obtained by Prof. Holmes from a stratum of ferruginous sand, two inches thick, exposed on the side of a bluff, on Goose creek, about twelve miles from Charleston.

Having expressed a desire to see the locality from which the tooth just mentioned was obtained, Prof. Holmes afforded me the opportunity of doing so. The bluff is about thirty feet high ; its.base is formed of a Pleiocene limestone, about fifteen feet thick, and composed of the debris of marine shells; above this is the stratum of ferruginous sand, of Post-Pleiocene age, containing numerous pebbles and rolled fragments of bone, all blackened, like the tooth obtained from the same position. Overlying the latter stratum there is a layer of stiff blue clay, about two feet in thickness, and above this there are about twelve feet of sand and earth mould.

* Proc. Acad. Nat. Sci, Phila., III, 1847, 622. 
A similar blackened tooth, represented in figure 6, Plate XV, was obtained from the same formation, at Doctor's Swamp, John's Island.

Figures 2-5, represent four superior molars of the extinct Horse, from the Post-Pleiocene bed of the Ashley river, all exhibiting a greater complexity of the enamel folding than is the case in the recent Horse. These specimens are hard, brown in color, and range from two, to about three and a half inches in length, and measure from one inch two lines, to one and a quarter inches in antero-posterior diameter, and from one inch, to one inch and two lines in transverse diameter.

Figure 7, Plate XV, represents a last upper molar of the right side, also from the PostPleiocene bed of the Ashley river. The specimen is dense, brown in color, and well preserved, except having lost its exterior cement. Its enamel folding is quite complex; and it measures two and a quarter inches in length, sixteen lines in antero-posterior diameter, and eleven lines transversely.

The Museum of the Academy of Natural Sciences, of Philadelphia, contains a number of teeth of the extinct Horse, of which six upper and seven lower molars were found in association with remains of Mastodon, Elephas, Megalonyx, Mylodon, Ereptodon, Bison latifrons, Ursus, Felis atrox, etc., in ravines in the vicinity of Natchez, Mississippi; two upper molars, were obtained by Dr. Dickeson from one of the islands of the Mississippi, near Natchez; and an inferior molar was found in association with remains of Mastodon, "Elephas, Megatherium, etc., in the excavation of the Brunswick canal, near Darien, Georgia.

The teeth from the vicinity of Natchez are usually well preserved, except that they are generally deprived of their exterior cement, and the dentine is more or less friable. They vary considerably in point of comparative size and degree of complexity.

Figures 24-26, Plate XVI, represent specimens of inferior molars of the extinct Horse, obtained by Dr. Dickeson from the ravines of Natchez. They vary from two and a half, to four and a quarter inches in length, thirteen and a half, to fifteen lines in breadth, and six and a half, to eight lines in width. The tooth represented by figure 25, appears to have belonged to the temporary series, which are larger than their permanent successors.

Figure 27 represents an inferior fourth molar, which, with a portion of the jaw and the impress of the third, fifth, and sixth molars, are preserved in a thick fragment of compact peroxide of iron. The specimen, together with an upper molar of the same animal, and a portion of the lower jaw of Felis atrox, similarly preserved, were obtained by W. H. Huntington, Esq., from the vicinity of Natchez, and presented to the American Philosophical Society. The fourth molar, above referred to, is about three and three-quarter inches long, and does not differ from its correspondent in the recent Horse.

Figures 11-15, Plate XV, represent specimens of superior molars, from the Natchez ravines, all with the enamel more complexly folded than in the corresponding teeth of the domestic Horse, as may be seen by comparing them with figure 1, representing the upper molar series of the latter. Figure 13, apparently represents an upper molar of the temporary series. The others measure three and a half, to three and three-quarter inches long; fourteen. to sixteen lines broad; and twelve, to fourteen lines wide. 
Figures 17, 18, represent two specimens of upper last molars, above mentioned, from one of the Natchez islands. They are hard, blackened, and water-rolled, and neither differ in size nor complexity from their homologues of the domestic Horse.

Figure 23, Plate XVI, represents a remarkably well preserved specimen of a lower molar, above referred to, from Georgia, where it was discovered by J. H. Couper, in association with equally well preserved remains of other extinct animals. The tooth is brown in color; and it neither differs in size nor form from its homologue in the recent Horse.

In the collection of fossils of Prof. Holmes, there is the specimen of an upper first large molar, labelled from Texas, represented in figure 10, Plate XV. The tooth is of the largest comparative size, and exhibits the highest degree of complexity in the folding of its enamel; in both of which characters it differs in such a remarkable degree from the corresponding tooth, represented in figure 8, from the Post-Pleiocene formation of SouthCarolina, that it appears hardly possible that these two teeth should belong to the same species of Horse.

Specimens of upper and lower molars, and incisors, have been submitted to my inspection, by Prof. E. Emmons, who informed me they were obtained from North-Carolina. One of the specimens, a remarkably well preserved superior molar tooth, is represented in figures 16, Plate XV, and 28, of Plate XVI.

Figure 9, Plate XV, also represents a well-preserved superior molar tooth, being the first of the right side. It was sent to me for examination by Dr. B. F. Shumard, who obtained it from the Illinois bluffs, (the quartenary formation, or the bluff formation of Missouri, of the Geological Report,) six miles west of St. Louis.

The Cabinet of the Academy of Natural Sciences, of Philadelphia, also contains the following remains of the extinct Horse :

A tibia, from the ravines of Natchez, Mississippi, obtained by Dr. Dickeson, together with the remains of other extinct animals, previously mentioned. The bone is sixteen inches long, five and a quarter inches broad at the proximal extremity, and three and three-quarter inches broad at the distal extremity.

A metacarpal bone, a calcaneum, a metatarsal bone, two first phalanges and a third phalanx, and an axis, which together with remains of Elephas and Mastodon, from Big-bone-lick, Kentucky, were presented to the American Philosophical Society, by Thomas Jefferson, President of the United States.

The metacarpal bone is ten inches long, and four and a quarter inches in circumference at the middle of its shaft ; the tuberosity of the calcaneum is two and a half inches in depth; the metatarsal bone is one foot long, and about five inches in circumference at its middle; the first phalanx is three and three-quarter inches long, and two and a half inches broad at the proximal extremity; the last phalanx measures two and three-quarter inches on its anterior slope, and four inches broad; and the axis is six and a half inches long.

Lastly, the same collection contains a second phalanx, two inches long and two and a quarter inches broad, from Benton county, Missouri, where it was found in association with large quantities of the remains of Elephas, Mastodon, and Bootherium cavifrons. 
Since writing the foregoing chapter, which is, however, partially amended, Dr. F. V. Hayden, the zealous geologist and explorer, attached to Lieut. Warren's Expedition to Nebraska, discovered on the Niobrara river, a formation supposed to be Pleiocene, which contains a most wonderful quantity of equine remains, comingled with the remains of many other extinct animals. In the collection of Dr. Hayden, which I have had the opportunity of inspecting, I have detected the remains of apparently eight species of six genera of equine animals. A particular description of these interesting remains is reserved for publication in Lieut. Warren's Report of his Expedition.

\section{H I P P O T H E R I U M . - K A U P. HIPPARION.-DE Christol.}

\section{H I P P.O THER I U M VEN U S T U M .}

Plate XVI. Figs. 32, 33.

Hipparion venustum, Leidy, Proc. Acad. Nat. Sci., Philadelphia, VI, 241.

Among the most interesting of the fossils discovered, by Prof. Holmes and Capt. Bowman, in the Post-Pleiocene beds of the Ashley river, are two molar teeth of a species of the equine genus Hippotherium. These were the first remains of the latter discovered in America, and they indicate the smallest known species.

Both specimens are from the upper jaw; and they are well characterized, not only by the isolation of the internal median enamel column, but also by the complex plication of the interior or central enamel columns.

The larger specimen (Plate XVI, fig. 33, ) is firm in texture; has the enamel stained jet black, and the dentine and cement gray. It is broken at the bottom, and has lost its inner median enamel column. In its present condition it is two inches in length; and possesses a moderate degree of internal and posterior curvature. Its antero-posterior diameter is eight and a half lines, and its estimated transverse diameter at the middle is seven lines.

The smaller specimen (Plate XVI, fig. 32,) is firm in texture, and brown in color. It is half worn down; tapers toward the root; and is little less than an inch in length. Its inner median enamel column is antero-posteriorly reniform. The breadth of the tooth is seven and a half lines, and the transverse diameter five and a half lines.

Plate XVI, Fig. 33. The triturating surface of a superior molar tooth of Hippotherium venustum, the size of nature. Specimen discovered by Prof. Holmes.

Fig. 32. The triturating surface of a superior molar tooth of Hippotherium venustum, magnified two diameters. Specimen discovered by Capt. Bowman. 
Order, PACHYDERMATA.

Genus, TAPIRUS.-BRisson.

\section{TAPIRUS AMRICANUS FOSSILIS. TAPIRUS HAYSII.}

Plate XVII. FIgs. 1-12.

Tapir, Carpenter, Am. Jour. Sci., xlii, 390 ; Ibidem, 2 d ser., I, 247.

Tapirus Americanus (?) fossilis, Leidy, Proc. Acad. Nat. Sci., Phil., IV, 180.

Tapirus Haysii, Leidy, Ibidem, VI, 106 ; VII, 201.

I have personally had the opportunity of inspecting remains of the Tapir, found in Texas, Louisiana, Kentucky, Mississippi, Indiana, Ohio, and South Carolina, proving an extensive range of this animal at one time over the country of the United States.

The late Dr. Carpenter, of New-Orleans, described several portions of jaws with teeth, (Plate XVII, figures 1-6,) from the banks of the Brasos river, near San Fillipe, 'Texas, and an isolated molar from near Opelousas, Louisiana. The specimens, which were presented by Dr. Carpenter to the Academy of Natural Sciences of Philadelphia, on close comparison are not found to differ from the corresponding parts of the living Tapirus Americanus, of South America, more than do a number of examples from the latter species among themselves.

The collection of the Academy of Natural Sciences, also contains an inferior molar tooth of the Tapir, found near Natchez, Mississippi, in association with the remains of Mastodon, Megalonyx, etc. The specimen corresponds in form and size with its homologue in the recent Tapir.

The collections of Prof. Holmes and Capt. Bowman, from the Post-Pleiocene deposits of the Ashley river, contain a number of small fragments of molar teeth, and one nearly entire and unworn crown of a second lower molar, (figures 11, 12,) which have the same character of form and size as in the living Tapir. Besides these, the same collections contain fragments of lower molars, and two nearly entire crowns of upper molars, (figures 2,3, having the exact form of the corresponding teeth of the T. Americunus, but larger in size. The more perfect of these specimens are represented in figures 2, 3, Plate XVII.

Dr. Isaac Hays presented to the Academy of Natural Sciences of Philadelphia, an inferior molar tooth of a Tapir, supposed to have been obtained from Big-bone-lick, Kentucky. The specimen corresponds to the penultimate molar of the T. Americanus, but is larger; measuring twelve and a half lines antero-posteriorly, and ten and a quarter transversely. This tooth, which is represented in figures 7, 8, Plate XVII, I have suspected to indicate an extinct species, to which the name of Tapirus Haysii was given, though it may be questioned if it had not already been noticed by Dr. Harlan, under the 
name of Tapirus mastodontoides. ${ }^{*}$ The specimen described by Dr. Harlan, on which the latter was founded, is also stated to have been a lower molar, from Big-bone-lick. Mr. Cooper, however, considered the tooth, described by Dr. Harlan, as the first temporary molar of a Mustodon, $\uparrow$ and in this view he is sustained by M. De Blainville, + and also by Dr. Hays, who informs me he had an opportunity of inspecting the specimen.

Col. B. L. C. Wailes has submitted to my examination a fragment of the left side of the lower jaw, of the larger variety of the Tapir, discovered in Mammoth ravine, Adams Co., Mississippi, in association with remains of the Mastodon and Megalonyx. The specimen represented in figures 4,5 , contains the posterior two molar teeth, which only differ from those of the recent Tapir in their larger size. Comparative measurements of this fossil with the lower jaw of the T. Americanus, are as follows:

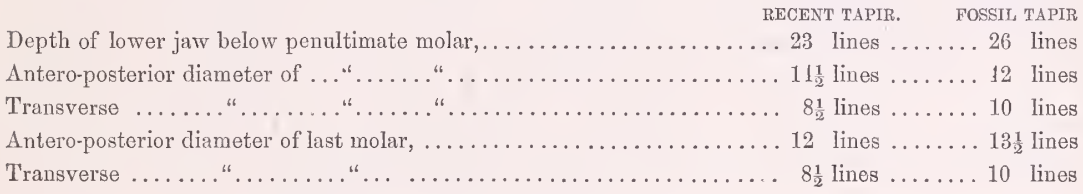

A lower back molar, of an old individual of the larger variety of the fossil Tapir has been sent to me for examination by Dr. J. G. Norwood. The specimen was obtained by Mr. Francis A. Lincke, from the banks of the Ohio river, near Evansville, Indiana, where it was found with remains of Megalonyx, Bison Americanus, Equus, Cervus, and Canis primavus. It is represented in figures 9,10 ; and it has the crown worn to a level with the bottom of the transverse valley, and has long divergent fangs. Its diameters antero-posteriorly and transversely are nearly equal, being about ten lines.

A short time since, Prof. J. Brainerd, of Cleveland, Ohio, loaned me for examination an interesting specimen, consisting of a much mutilated fragment of the lower jaw, of the smaller variety of the extinct Tapir, partially imbedded in a block of bluish clay. The fragment contains two broken teeth and part of a third; and belonged to a young individual. The specimen, Prof. Brainerd informs me, was found in the valley of Yellow creek, Columbiana Co., Ohio, in an erosion of the coal series, and was covered with thirty feet of clay, two hundred and sixty-two feet above Lake Erie, and one hundred and eighty-six feet above low water in the Ohio river.

* Med. and Phys. Researehes, 264; Fauna Amerieana, 224. Sinee writing the above, the speeimen, upon whieh Dr. Harlan eharaeterized this supposed speeies, has been found in his eolleetion, and is now deposited in the eabinet of the Aeademy of Natural Scienees, Philadelphia. It is undoubtedly a first temporary molar of the Mastodon. See Proe. Aead. Nat. Sei., 1858, p. 12.

† Amer. Month. Jous: Geol., Note, 163.

† Osteog. Gen.; Tapir, 34. 


\section{Genus, DICOTYLES.-Cuv. \\ DICOTYLES FOSSILIS. \\ Plate XVII. Figs. 13, 14.}

Capt. Bowman's collection of Ashley fossils contains specimens of the crowns of the two back molar teeth of the lower jaw, represented in figures 13, 14, Plate XVII, which have almost the same size and form as the corresponding teeth of the collared Peccary Dicotyles torquatus. The collection further contains fragments of two upper molar teeth, which had about the same size as those of the Dicotyles labiatus. The specimens apparently indicate a different species from the extinct Dicotyles compressus of the Western States, and they perhaps belonged to a species different from the recent ones, but the remains are insufficient to determine this question positively.

\section{Genus, ELEPHAS.-LINN. \\ ELEPHAS AMERICANUS. \\ Plate XVIII.}

Elephas primigenius, Blumenbach. Remains of an extinct elephant found in North America, and referred to this species by numerous authors.

Elephas Americanus, Leidy, Ancient Fauna of Nebraska, p. 9.

Small fragments of teeth and bones, usually much water worn, of the extinct elephant, are not unfrequeutly found in the Post-Pleiocene deposits in the vicinity of the Ashley river.*

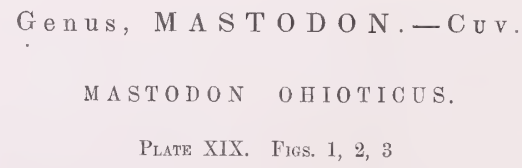

Mastodon Ohioticum, Oken.

Mastodon giganteum, Cuvier, Ossem. Fos., and many other authors.

Tetracaulodon, Godrnan.

* Since the above was written a perfect tooth has been discovered and figured in Plate XVIII.-(F. S. H.) 
Small fragments of teeth and bones, are found in the Post-Pleiocene deposits of Ashley River, apparently referrable to the Mastodon ohioticus. *

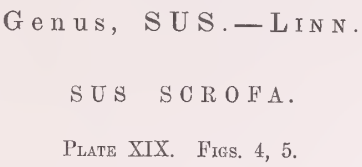

Remains referrable to this species, from the shores of the Ashley River, contained in the collections of Prof. Holmes and Capt. Bowman, are believed, by the writer, to appertain to the recent introduced domestic hog.

\title{
RUMINANTIA.
}

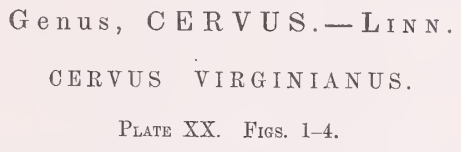

Remains of a species of deer about the size of the Cervus Virginanus, have been found in association with those of extinct animals near Natchez, Mississippi, in New Jersey, and in other localities.

The collections of Prof. Holmes and Capt. Bowman contain fragments of antlers, portions of jaws, and teeth, from the Post-Pleiocene beds of the Ashley river, not differing from corresponding parts of the skeleton of the recent Cervus Virginianus, to which species they probably belonged. See figures 1 to $4 a$, Plate XX.

\section{Genus, BISON.}

\author{
BIS ON LATIF R N S. \\ Piate XVII. Figs. 15,16 .
}

Bos latifrons, Harlan, Fauna Americana 273; Med. and Phys. Researches 276.

T Several perfect teeth of this species have also been discovered since the above was written. See Plate XIX, figs. 1, 2, 3.-(F. S. H.) 
Bison latifrons, Leidy, Proc. Acad. Nat. Sci. Phil. vi, 117; Mem. on ext. 8 p. of American ox, 8.

Sus Americanus, Harlan, Am. Jour. Sci. xliii, 143.

Harlanus Americanus, Owen, Proc. Acad. Nat. Sci., Phil., III, 94; Jour. Acad. Nat. Sci., I, 18.

Harlanius, Owen, Bronn. Leth. Geog., 846.

Remains of the extinct broad-fronted bison have been discovered in Kentucky, Mississippi, Texas, and Georgia, in association in these different localities with remains of Elephas, Mastodon, Megatherium, Megalonyx, Mylodon, Ereptodon, Equus, Cervus, Canis, Ursus, Felis, etc.

In the collection of Capt. Bowman, there is a second premolar tooth of the right side of the hpper jaw, from the Post-Pleiocene formation of the Ashley river, which I suspect to belong to the Bison latifrons. The specimen presents nothing characteristically different from the corresponding tooth of the recent bison. It is represented in figures 15, 16, Plate XVII; and its crown measures eleven lines in antero-posterior and transverse diameter.

\section{Genus, B O S. - Lin N. \\ BOS TAURUS.}

Plate XX. Figs. 5-9, 9a.

Remains of a species of ox, of the size of the recently introduced domestic animal, found mingled with Post-Pleiocene fossils on the banks of the Ashley river, are considered to belong to the latter.

\section{Genus, OVIS.- L I N . \\ OVIS AMMON. \\ Plate XX. Figs. 6, 6a.}

Remains also of the domestic sheep, are found mingled with the Post-Pleiocene fossils of the Ashley river. 


\section{EDENTATA.}

Genus, MEGA THERIUM.-CUviER.

M E G A THRI UM MIRABILE.

PLATE XX. Figs. 8, 8a.

Megatherium mirabile, Leidy, Mem. Ext. Sloth Tribe, 49, 59.

Several small fragments of teeth of the Megatherium, in Prof. Holmes' collection were obtained from the Post-Pleiocene bed of the Ashley river. Previously to the discovery of these specimens, remains of the Megatherium had been found in no other locality of NorthAmerica, than in the State of Georgia.

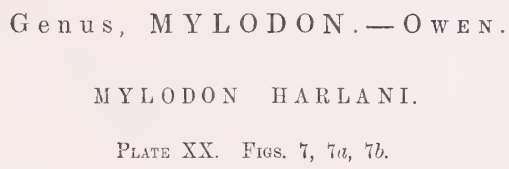

Eubradys antiquus, Leidy, Proc. Acad. Nat. Sci., Phil., VI, 241 ; Anc. Fauna Nebr., 10 ; Mem. Ext. Sloth Tribe, 58.

Two small fragments of lower molar teeth of Mylodon Harlani, were obtained from the Ashley Post-Pleiocene beds. One of the fragments is represented in figures 21, plate 16, of "a memoir on the extinct Sloth Tribe of North-America," by the author.

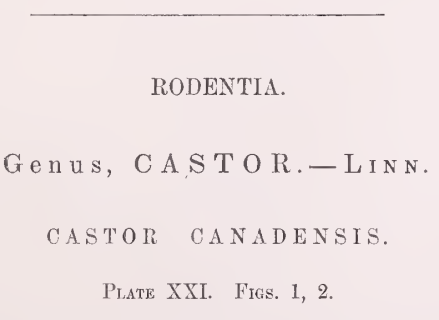

Castor Canadensis, Kuhl, Beit. z. Zoologie.

Castor Americanus, F. Cuv., Hist. d. Mammif. 
Castor fiber, Say, Harlan, etc.

Castor fiber, Wyman, Am. Jour. Sci., 2d ser. X, 61.

Remains of the Beaver are not unfrequently found throughout the United States, in recent deposits, in localities in which the animal is not now existing. Prof. Wyman has further described remains of the Beaver, found in association with those of Mastodon, Megalonyx, and Castoroides, in the vicinity of Memphis, Tennessee. The cabinet of the Academy of Natural Sciences, of Philadelphia, also contains portions of skulls and jaws with teeth, found together with remains of the Mastodon, in marshes in New-Jersey. Teeth of the Beaver, jet black in color, have likewise been obtained by Prof. Holmes and Capt. Bowman, from the Post-Pleiocene deposit of Ashley river.

Genus, HYDROCHOERUS.-BRIsson.

HYDROCHOERUS AESOPI.

Plate XXI. Figs. $3-6$.

Oromys Eesopi, Leidy, Proc. Acad. Nat. Sci., Phila., VI, 241.

Hydrochoerus Aesopi, Leidy, Proc. Acad. Nat. Sci., Phila., VIII, 165.

In 1853 I received from Prof. Holmes a small fragment of an incisor tooth, obtained from the Post-Pleiocene deposit of the Ashley river. The specimen I suspected to indicate a large rodent animal, allied to the South-American Hydrochoerus capybara, and characterized it under the name of Oromys Aesopi. Capt. Bowman's collection of fossils, from the Ashley river beds, subsequently received, was found to contain portions of two molar teeth, which prove the former specimen really to have belonged to a species of Hydrochoerus. More recently Prof. Holmes obtained an additional fragment of a molar tooth, from the Ashley Post-Pleiocene deposit.

The fragment of an incisor referred to, belonging to the lower jaw, is a little more than an inch in length, and measures five lines in breadth, but does not differ from the corresponding portion of the same tooth in the recent Capybara, except that the enamel is more strongly ridged, longitudinally, than in any of the specimens with which it was compared.

Of the two portions of molar teeth, of Capt. Bowman's collection, both belong to the left side of the lower jaw. One of them consists of the posterior three enamel folds or columns of the second tooth in the series, and the other consists of the anterior two columns of the last tooth. The former specimen measures four-and-a-half lines transversely and antero- 
posteriorly; and the latter measures six-and-a-half lines transversely, two-and-a-half lines antero-posteriorly. Neither differ, in any important character, from the corresponding portions of their homologues in the recent Capybara.

The portion of a molar, of Prof. Holmes' collection, consists of the anterior pair of columns of the third tooth of the left series of the lower jaw.

\section{Genus, L E P.U S. - L I N N. \\ LEPLS SYLVATICUS. \\ Plate X.II. Fig. 1.}

Lepus sylvaticus, Bachman, Leidy, Trans. Amer. Phil. Soc.

Remains, apparently, of the common Gray Rabbit have been found in association with those of other rodents, and of the extinct Peccary, near Galena, Illinois.

A few specimens of molar teeth, black in color, apparently belonging to this species, were obtained by Prof. Holmes and Capt. Bowman, from the Post-Pleiocene beds of the Ashley river.

\section{Genus, F I B E R. - C u v. \\ FIBER ZIBETHICUS. \\ PI.ATE XXII. FIGS. 1-4.}

Fiber zibethicus, Cuvier, Harlan, etc.

The collections of Prof. Holmes and Capt. Bowman contain numerous specimens of blackened molar teeth, together with a few incisors and fragments of jaws, from the Ashley Post-Pleiocene deposit, which neither differ in form nor size from the corresponding parts of the recent Musk-rat. 


\section{Genus, CASTOROIDES.-Foster.}

\section{CASTOROIDES OHIOENSIS.}

Plate XXII. Figs. 5-8.

Animal of the order Rodentia, Amer. Jour. Sci., XXI, 80.

Castoroides Ohioensis, Foster, Second Rep. Geol. Surv. Ohio, 81; Hall and Wyman, Brit. Jour. Nat. Hist., V, 385; Wyman, Am. Jour. Sci., 2d s. X, 62.

Remains of this most huge of all rodent animals, according to Prof. Wyman, have been discovered in New-York, Ohio, Tennessee, and Louisiana.* The cabinet of the Academy of Natural Sciences, of Philadelphia, contains the greater portion of an upper incisor, two upper molars, and two petrous bones of this animal, which were obtained in digging a well, forty feet below the surface, near Shawneetown, Illinois. In Plate XXII, figure 5, is represented the upper incisor above referred to.

Prof. Holmes' collection contains a small fragment of an incisor and of an upper molar tooth, from the Post-Pleiocene deposit of Ashley river.

Though the skull of Castoroides resembles that of the Beaver, the teeth differ totally in their form and constitution. The molar teeth of the former are constructed upon the same plan as those of the Capybara, consisting of a series of flat columns of dentine invested with enamel and held together by cement.

The upper incisors in section form a half ellipse with the plane inward. The anteroexternal convex surface is invested with thick and strongly fluted enamel, and the posterior surface is smooth and concave. The cutting extremity of these teeth is worn away as in the Musk-rat, that is to say into a deep depression on the inner side of the beveled surface. The lower incisors are trilateral in section, the inner and posterior sides smooth and slightly depressed, and the anterô-external surface convex and invested with enamel as in the corresponding upper teeth.

The fluting of the enamel surfaces of the incisors extends in a well-marked manner into the dentine.

* Amer. Jour. Sci., 2d s. X, 64 . 


\title{
CARNIVORA
}

Genus, PROCYON.-STorR.

\author{
P R O C Y N L O T OR.
}

Plate XXIII. Fig. 1.

Procyon lotor, Storr, Prod. Meth. Anim., 1780.

Procyon lotor, Desmarest, Audubon, Bachman, etc.

The collections, of Prof. Holmes and Capt. Bowman, from the Ashley Post-Pleiocene deposit, contain molar teeth, black in color, not differing in form and size from those of the recent Raccoon.

Plate XXIII. Fig. 1, Right side lower maxillary bone of the Raccoon, shaded tooth, a fossil, from the Ashley beds.

Locality. Ashley Ferry. Museum, College of Charleston.

\author{
Genus, A R C T D US.-LEIDY. \\ AR CTODUS PRISTINUS. \\ Plate XXiII. Figs. 3, 4.
}

Arctodus pristinus, Leidy, Proc. Acad. Nat. Sci. Phila., VII, 90.

The collection of Capt. Bowman contains the crown of a molar tooth from the PostPleiocene deposit of the Ashley river, which I suspect to indicate an extinct animal allied to the Bear. The specimen most resembles the corresponding portion of the lower left penultimate molar of the latter. It is oblong-oval in outline and is broader anteriorly than posteriorly, being the reverse condition to that in the Bear. On the inner side it is straight and nearly vertical, and on the outer side is convex and more deeply and equally bilobed than what appears to be its homologue in the latter animal. The triturating surface (Plate XXIII, figure 3), as in the Bear, is an oblong, superficial depression surrounded by a chain of hill-like tubercles, of which the largest pair extend across the anterior part of 
the crown. The enamel is strongly corrugated; and the specimen measures eleven-and-ahalf lines antero-posteriorly and eight lines at its widest part transversely.

Plate XXIII. FIg. 3, Penultimate lower molur; view of the triturating surface.

" 4, Lateral vien of same specimen, with restored fangs in outline.

Locality. Ashley Ferry.

Museum, College of Charleston.

\author{
Ge nus, C A N I S.- L I N . \\ CANIS FAMILIARIS. \\ Plate XXIV. Fig. 1.
}

Teeth and bones of the domestic Dog are found mingled with the Post-Pleiocene fossils on the shores of the Ashley river.

Plate XXIV. Fig. 1, Anterior portion of the skull of the dog. The shaded teeth indidicate the fossils from the Ashley beds.

Museum, College of Charleston.

\title{
MARSUPIALIA.
}

Genus, DIDELPHYS.-Lin

\section{DIDELPHYS VIRGINIANA.}

PIATE XXIII. Flg. 2.

Didelphys Virginiana, Shan, Gen. Zool. I, 1800.

Didelphys Virginiana, Desmarest, Harlan, Audubon, and Bachman, etc.

The fragment of a lower jaw, containing the last molar tooth, of an opossum, was obtained from the Post-Pleiocene formation of Doctor's Swamp, John's Island, ten miles south-west of Charleston.

Plate XXIII. FIG. 2, Left lower maxillary of Opossum; the shaded portion indicates the fossil fragment from John's Island. 
SIRENA.

\title{
Genus, MA NA T US.-RONDELET.
}

\section{MANATUS ANTIQUUS.}

Plate XXiv. Fig. 5-7.

Manatus antiquus, Leidy, Proc. Acad. Nat. Sci., Phil., VIII, 165.

Remains of the Manatus have been noticed in the later Tertiary deposits of New Jersey, Maryland, Virginia, and North-Carolina.

The cabinet of the Academy of Natural Sciences, of Philadelphia, contains the rib of a species of Manatus from the Miocene marl of New-Jersey. The collection of fossils, from the Ashley river Post-Pleiocene beds, contains a small fragment of a large rib of the Manatus, and among the fossils, of Capt. Bowman, from the same locality, there is a molar tooth perhaps of the same species. The tooth (Plate XXIV, figure 5,) most nearly resembles the sixth or seventh molar of the right side of the upper jaw of Manatus latirostris, Harlan, than, which it is considerably larger. It has no anterior basal ridge as in the latter species, but from both of the inner lobes the summits are prolonged in a curvelinear manner to the middle of the outer lobes. The antero-posterior and transverse diameters of the specimen are about nine-and-a-half lines.

Plate XXIV. Fig. 5, Inner view of upper molar.

" 6, View of the triturating surface of the same.

" 7, Outer view of the same.

Loçality Ashley beds.

Museum, College of Charleston.

\author{
Genus, PHYSETER. \\ P I Y S E T E R A N T I Q U U S. \\ Plate XXIV. Figs. 8, 9.
}

Physeter antiquus, Leidy, Proc. Acad. Nat. Sciences, Phila., VI, 378.

Remains of Spermaceti Whales, apparently of the same species, have been discovered in the Post-Pleiocene deposits of South Carolina and in the Miocene formations of Virginia. 
The remains, consisting of teeth and vertebræ, though presenting no character of importance by which to distinguish them from the recent Spermaceti Whale, nevertheless, are supposed to indicate a different species on account of their great age. A tooth of the Physeter antiquus, being the best of several specimens found in the Ashley Post-Pleiocene beds, is represented in figure 8 of Plate XXIV. It is of small size compared with the large ones frequently seen from the recent species, and although it is as large as any of the fossils we have had the opportunity of inspecting, the difference in size may depend on the difference of age of the individuals. Fig. 9, of the same plate, represents a tooth of quite perfect and recent appearance, discovered in an excavation in the vicinity of Charleston, which Prof. Holmes supposes to belong to the same species as the fossils of the Ashley beds.

PLATE XXIV. FIg. 8, Lower tooth of Pñyseter antiquus, Leidy, from Ashley beds.

" 9, Another tooth of more recent appearance, from Charleston heds.

Museum, College of Charleston.

\section{LEPIDOSTEID A.}

Gen us, LEPIDOSTEUS. - L A CEPEDE.

LEPIDOSTEUS BISON?

Plate XXV. Fig. 1.

Some small fragments of jaws, with teeth, of a species of Lepidosteus, have been found among the Ashley river fossils. One of these specimens is represented, at a, figure 1, Plate XXV, in position in its relation with the skull of the existing Lepidosteus bison.

PLate XXV. FIG. 1, Skull of recent Lepidosteus; shaded portion indicates the fossil tragment.

Locality. Simmons'.

Museum, College of Charleston. 


\title{
Genus, X I P H I A S. - L ins.
}

\author{
XIPHIAS ROBUSTUS.
}

Plate XXVII. Figs. 3-5.

Remains of an extinct species of Sword-fish, are frequent in the Eocene formations of South Carolina, to which the above name has been given. The anterior extremity of the mouth of this species is represented in figure 5, Plate XXVII. Small fragments of jaws, apparently of the same species, as represented in figures 3 and 4 of the above plate, have likewise occasionally been found in the Post-Pleiocene beds of the Ashley river.

\section{Plate XXVII. Figs. 3 and 4, Fragments of Xiphias robustus, Leidy. " 5, Extremity of the upper jaw from the Eocene. \\ Localtity. Ashley beds. \\ Museum, College of Charleston.}

\author{
G enus, PASTIN A C A. - C u v. \\ PAST INACA HASTATA? \\ Plate XXVII. Figs. 1, 2.
}

Remains of a Sting-ray, consisting of the fragment of a spine, and a pair of co-ossified vertebræ were found in the Post-Pleiocene deposit of Simmon's Yonges Island.

Family, SQUALIDA.

The sharks are represented in the collection of Pleiocene and Post-pleiocene fossils, by a dozen specimens of teeth, apparently belonging to five different species, but they are suspected by the writer to appertain to the Eocene period.

Two of the teeth, the largest specimen of the collection, of which one is represented in figures 1, 2, of Plate XXVI, have the form of the anterior-superior teeth of certain existing species of Carcharias, but appear to be solid as in the genus Carcharodon. The crown is moderately thick and straight, with the lateral borders equally curved and coarsely denticulate. The enamel is smooth, and there are no lateral cusps. The inner surface of the root slopes outwardly, and presents at its middle a vascular foramen. The points of the roots are bent outwardly; and the intervening surface externally is concave. 
Two small teeth of the collection, represented in figures 3, 4, of Plate XXVI, resemble inferior teeth of the existing Carcharias Milberti? of our coast. The crown of the smaller specimen has its lateral borders obscurely denticulate. The larger specimen lias the base of its crown widely expanded, and the lateral borders distinctly derticulate. The root in both specimens, internally at the middle, is divided by a vertical sulcus.

A single tooth, represented in figures 5 and 6 of Plate XXVI, belongs to the genus Lamna. The crown is smooth externally, and slightly corrugated towards the base internally. On each side it is provided with a small uncinate denticle. The root is thick, prominent, and divided by a sulcus at the middle internally; and has its extremities prolonged downward.

Another tooth, represented in figure 7 of Plate XXVI, belongs to the genus Galeocerdo. The anterior border of the crown is distinctly denticulated; the upper portion of the posterior is feebly so, and the lower expanding portion coarsely.

A minute tooth, represented in figure 8 of Plate XXVI, has a trilobate crown, with a thick, quadrate root.

The remaining specimens, of which several are represented in figures 9-14, of Plate XXVI, appear to be symphysial and extreme lateral teeth. They have a conical, uncinate crown, with an expanded base, and a wide, thick, trilobed root. We are unable to refer them to any genus; perhaps they belong to Carcharodon.

I S C H Y R H I Z A. - L E I P .

I S C II Y R H I Z N I R A.-- LEIDY.

Plate XXV. Figs, 3-9.

Ischyrhiza mira, Leidy, Proc. Acad. Nat. Sci.

Ischyrhiza antiqua, Leidy, Proc. Acad. Nat. Sci.

Ischyrhiza antiqua, Leidy, Emmons' Rep., N. C., Geol. Surv.s p. 225.

Teeth of a large sphyrænoid fish have been discovered in the green sand formation of New Jersey and Mississippi, and upon the Neuse river, North Carolina, which have been referred to an extinct genus under the name of 1schyrhiza. Figures 3-8 of plate XXV, represent the teeth of the same genus discovered in South Carolina.

All the specimens which have come under the inspection of the author are imperfect, except the one represented in plate XXV; nor have we been able to arrive at a positive conclusion whether they indicate more than a single species. If they belonged to one 
species, the localities in which its remains have been found, would prove it to have extended from the green sand period, through the tertiary period, and to have become extinct just prior to the present period.

The teeth correspond with the largest anterior teeth of both upper and lower jaws of the Barricuda (Sphyræna barricuda, but indicate a much more powerful and equally voracious fish.

The specimen represented in figures 3 and 4 exhibits well the form of these remarkable teeth. Its crown inverted, with smooth shining enamel, is laterally compressed conical, with an antero-posterior sigmoid flexure in the length. Two-thirds of the posterior border from the point, and the whole of the anterior border are trenchant. The apex is rather abruptly pointed, and appears to be inserted with thicker enamel than the other portion of the crown.

The root or fang of the tooth presents a remarkable anatomical character in its gradual expansion to the base of attachment to the jaw. It is nearly as long as the crown is quadrilateral, and slightly unsymmetrical. Its base is divided antero-posteriorly by a broad cleft, deepening in front and behind, and on the outer sides is vertically grooved.

The teeth of the Ischyrhiza have a cavity in the interior, extending from the fang into the crown, but presenting no communication with the exterior.

Plate XXV. Fig. 3, Lateral view of a tooth of Ischyrhiza mira, Leidy.

" 4, Anterior view of the same specimen.

" 5, Lateral view of another specimen.

" 6, Anterior vien of the same.

"7, Base view of the same.

" 8, Base view of figs. 3 and 4.

Locality No. 3. Ashley beds.

No. 5. Darlington, (Meiocene?) Museum, College of Charleston.

\section{T R I C H I R U S.}

\section{TRICHIURUS LEPTURU FOSSILIS.}

Plate XXV. Fig. 2.

Teeth of a ribbon fish, not differing in form nor size from the large anterior teeth of the upper jaws of the existing Trichiurus lepturus, have been discovered by Prof. Holmes in the Post-Pleiocene formation at Simmons'.

Two of the specimens represented in figure 2 of plate XXV, exhibit the remarkable 
characters of these teeth. In form they are elongated conical, compressed laterally and curved backward; with the anterior border trenchant, and with the apex barbed posteriorly.

PLATE XXV. FIg. 2, Skull of recent Ribbon fish; the two large barbed teeth shaded, indicate the fossits from Simmons'.

Museum, College of Charleston.

\section{Gen $\mathrm{us}$, A L L I G A T O R. - C u v. \\ ALLIGATOR MISSISSIPIENSIS. \\ Plate XXVII. Figs. 6, 7.}

Remains, consisting usually of much mutilated teeth or fragments, referable to the Alligator, are frequently found among the Post-Pleiocene fossils of the Ashley river. Fig. 7, Plate XXVII represents two specimens of teeth from this locality.

Plate XXVII. FIg. 6, Right side lower jaw of the Alligator, reduced to one-fifth natural size.

“ 7, Two teeth fossil from Ashley beds.

Museum, College of Charteston.

CHELONIA.

Genus, TESTUDO.-BRONGNIRT.

Plate Xxvili. Figs. 1-4.

Remains of several species of Turtles are found in the Post-Pleiocene deposit of the Ashley river. In Plate XXVIII, figure 1, the vertebral extremity of a costal plate of a huge species is represented. The specimen measures at its widest part six inches, from which position it narrows outwardly. In thickness the specimen measures an inch and a quarter.

The remaining figures of the same plate exhibit the fragment of a costal plate and two marginal plates of a smaller, and perhaps a different species of Turtle from the former. 


\section{.}

. 


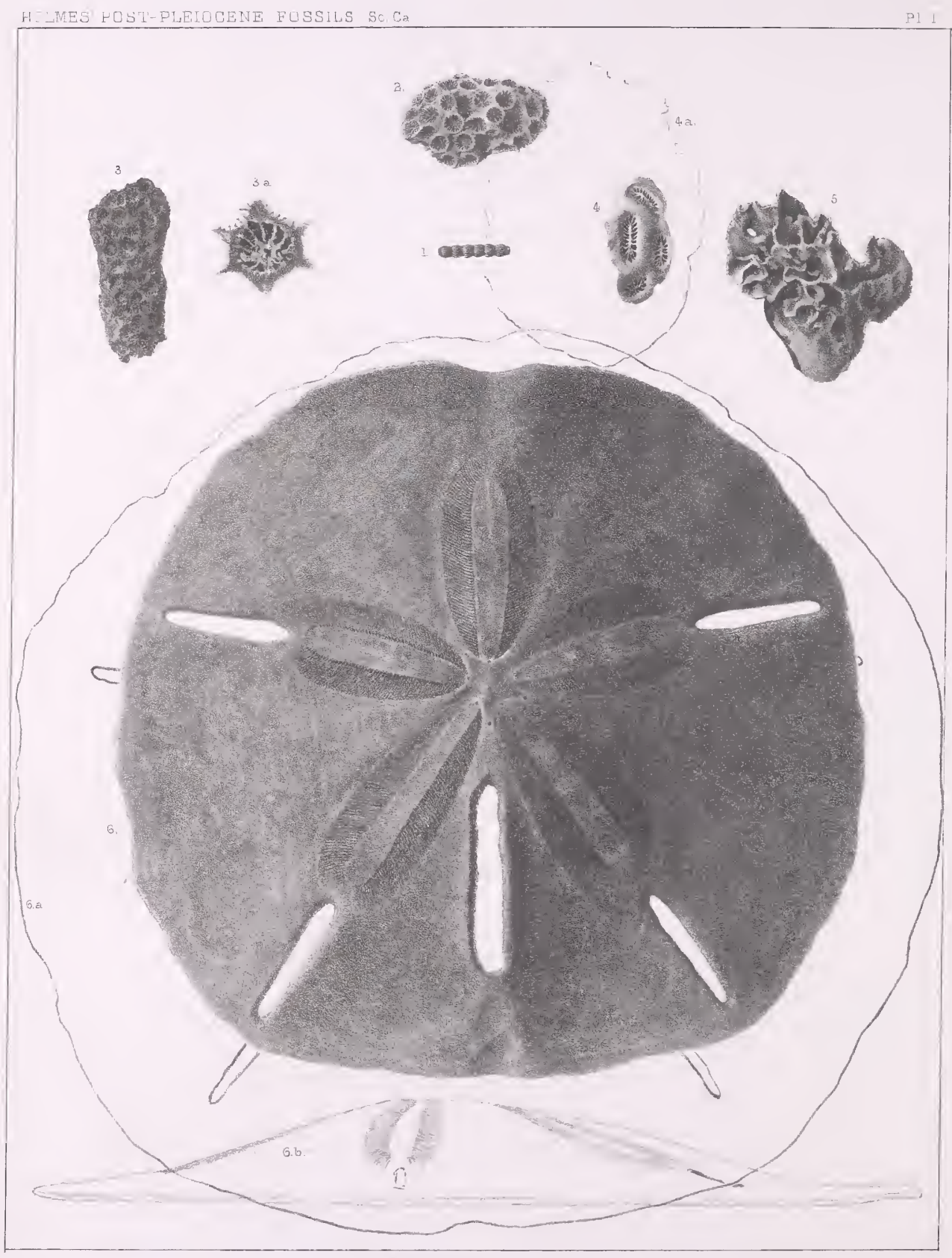

Fros. Trature dy D G. Platen
Charleston So $\mathrm{Ca}$ 


\title{
POST-PLEIOCENE FOSSILS.
}

\author{
S O U TH - C A R OLINA.
}

PLATE I.

F ORAMINIFERA.-POLYPARIA.-BRYOZOA.-ECHINID E. FORA MINIFERA.

Fig. 1. Nodosaria OBTUSA. Magnified. Page 1.

POLYPARIA.

Fig. 2. ASTRAA BELLA. Page 1.

“ 3. ASTRXA CRASSA. Page 2.

"3a. Cell magnified.

“ 4. ASTRAiA PETROSA. Four cells, natural size. Page 2.

"4a. Outline of the fragment.

\section{B R Y ZOA.}

Fig. 5. REPTOCELLEPORARIA INFORMATA. Incrusting a fragment of oyster shell, Page 6. For other P. P. BryozoA, see Plate II., fig. 4.

ECHINID A.

Fig. 6. MELLITA QUINQUEFORA. Variety, Ampla. View from above. Page 3.

“ $6 a$. Outline of largest specimen yet discovered.

" 6b. Profile of the same. 


\title{
POST-PLEIOCENE FOSSILS.
}

\author{
SOU T H - C A R OL I N A.
}

PLATE II.

\section{ESCHINIDE.-BRYOZOA.-CIRRIPEDA.-CRUSTACEA.-LANELLIBRANCHIATA. ES C H I N I D $\mathrm{A}$.}

Fig. 1. ECHINUS VARIEG ATUS. Page 4.

" 1 a. Spines of the same.

" 2. ANAPESUS CAROLINUS. Page 5.

" $2 a$. Spine of the same.

“ 3. SCHIZASTER ATROPOS, with restored outline. Page 5.

B R Y Z A.

Fug. 4. LUNUlites Dentidulati. Magnified. Page 6.

" 4a. Profile, natural size.

" 4b. Outline of base, natural size.

For Reptocelleporaria informata, see Plate I., fig. 5.

C I R R I P E A.

Fig. 5, BALANUS EBURNEUS. Page 7.

" $5 a$. Aperture, viewed from above.

\section{R U S T CEA.}

Fig. 6. CALAPPA MARMORATA. Page 8.

" 7. PSEUdOCARCINUS MERCENARIA. Page 8.

" 8. GUIA PUNCTATA. Page 8. LUPA DICANTHA. Not figured. Page 9.

\section{A M E L L IBR A N CHI A TA.}

Fig. 9. OSTREA VIRGINIANA. Page 9.

" 9a. Variety PROCYON. Page 10.

" 10. OSTREA FUNDATA. Page 11.

" 11. ANOMLA EPHIPPIUM. Page 11.

" 12. PECTEN DISLOCATUS. Page 12. LIMA GLACIALIS. Not figured.

* 13. PlicatUla CRISTAta. Page 13. 


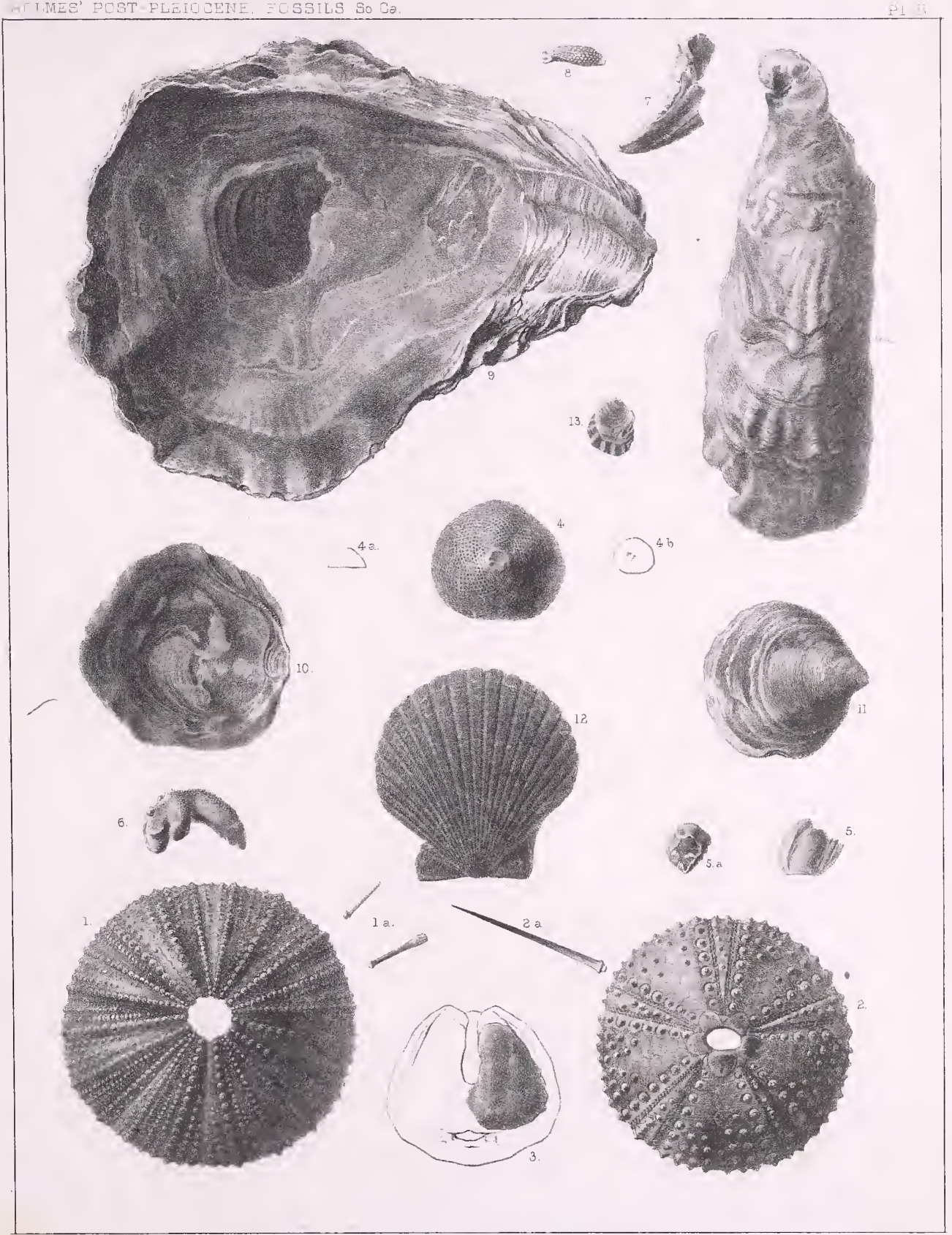

From Mature by C.G. Platen.

Charleston So Ca 


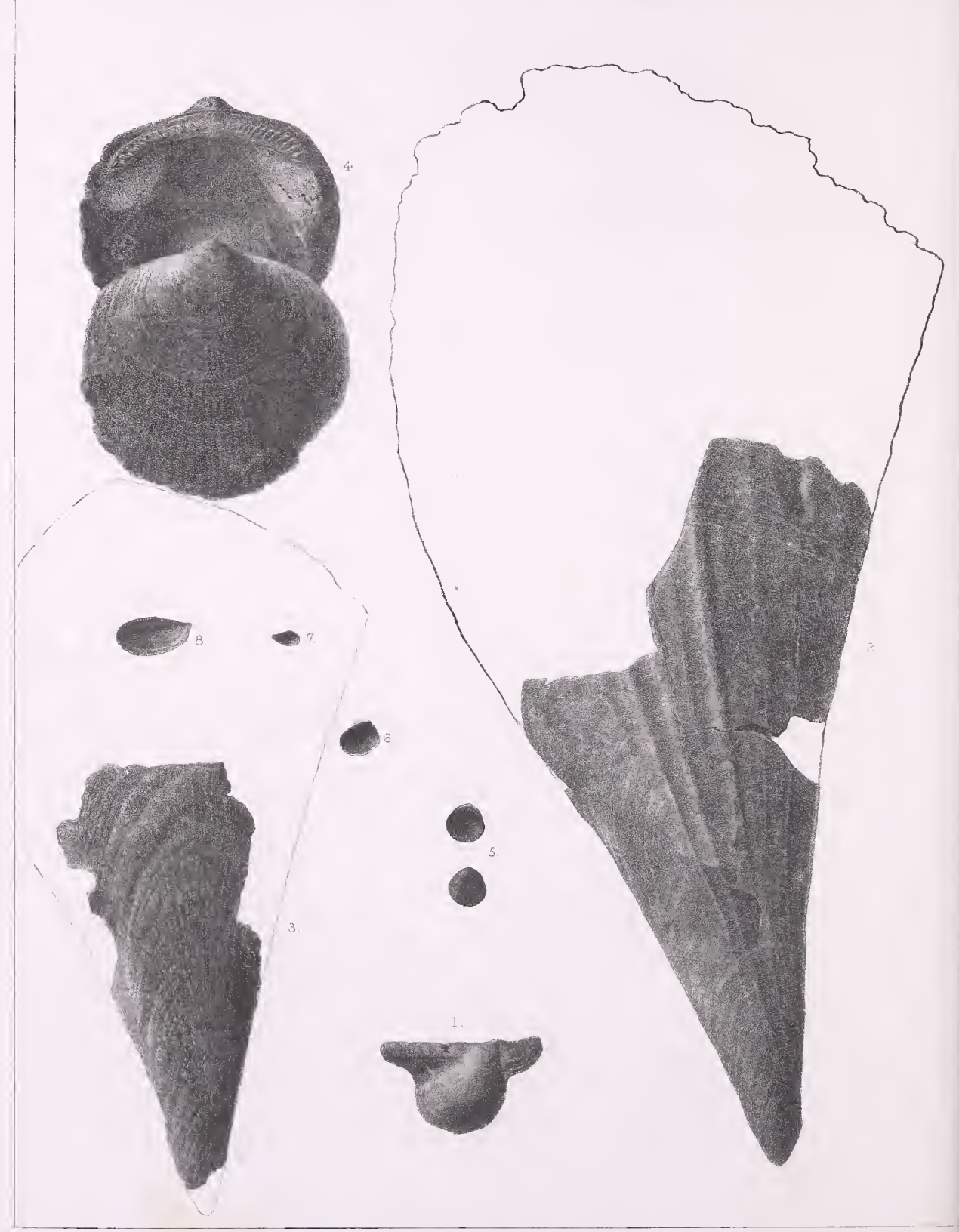

From Nature by C. G Platen Charleston. So $\mathrm{Ca}$ 


\title{
POST-PLEIOCENE FOSSILS.
}

\author{
S OUTH-CAROLIN A.
}

PLATE III.

A VICULID E. - A R CAD R.

A V I C U LID $\mathbb{A}$.

Fig. 1. AVtCUla ATlantica. Page 14.

" 2. PINNA SEMINUDA. Page 14.

" 3. PINNA MURICATA. Page 15.

$$
\text { A R CAD } A \text {. }
$$

Fig. 4. PECTUNCUlus CAROLInEnsis. Page 15.

“5. PECTUNCULUS CHARLESTONENSIS. Page 16.

" 6. NUCULA PROXIMA. Page 17.

“7. NUCUla ACUTA. Page 16.

“ 8. LEda Limatula. Page 18. 


\section{POST-PLEIOCENE FOSSILS. \\ S OU T H - C A R OLIN A.}

\section{PLATE IV.}

\section{ARCAD E.}

Fig. 1. ARCA INCONGRUA. Page 19.

" $1 a$. View of hinge and beaks.

" 2. ARCA AMERICANA. Page 19.

“ $2 a$. End view.

" 3. ARCA LIENOSA. Page 20.

" $3 a$. View of hinge.

" 4. ARCA PONDEROSA, Page 21.

" 4a. View of hinge.

"5. ARCA TRANSTERSA. Page 21.

" $5 a$. View of hinge.

" 6. ARCA CALLATA. Page 22.

" $6 a$. Vierv of hinge. 


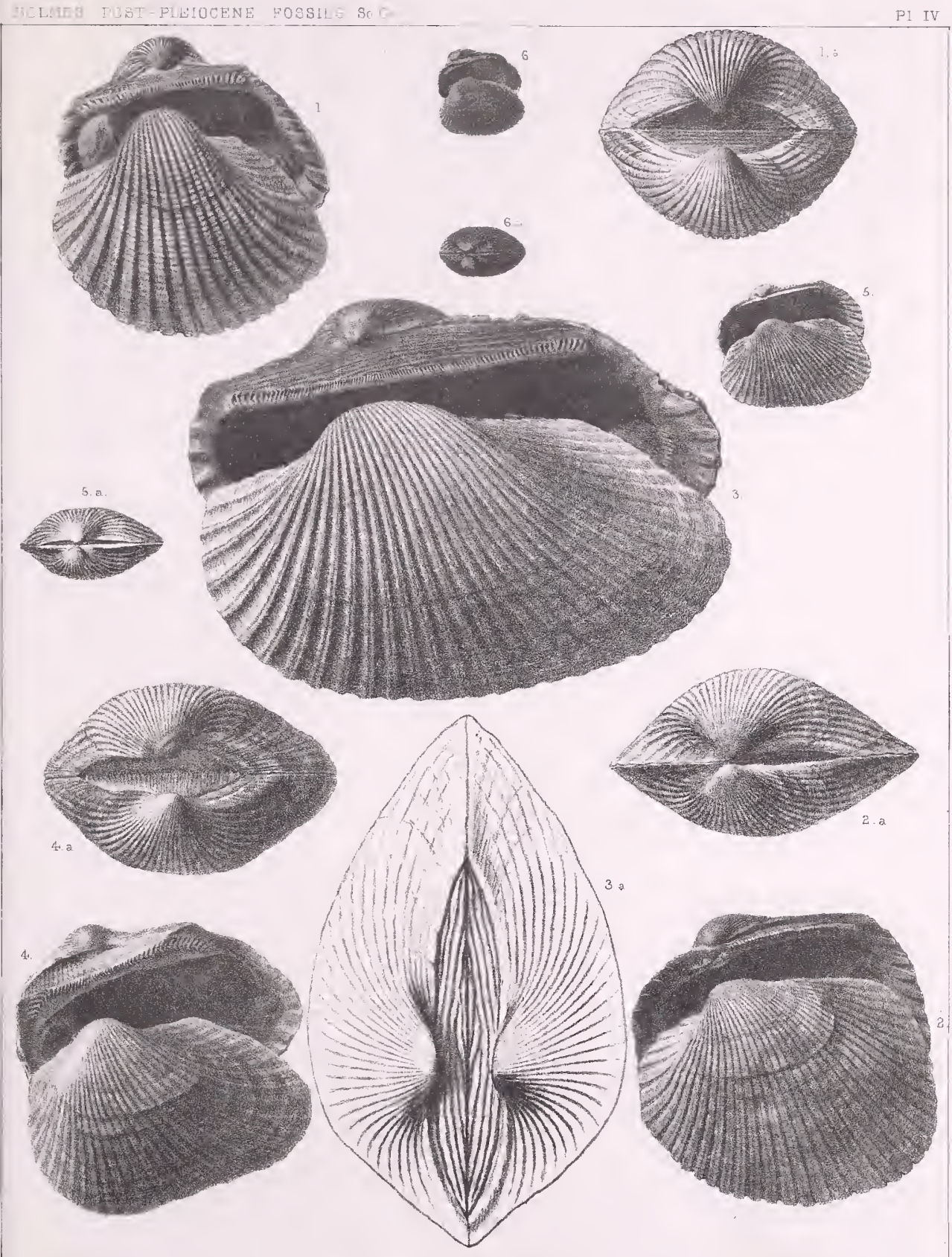

From Nature by C G Platen

Charleston So Ca 



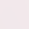




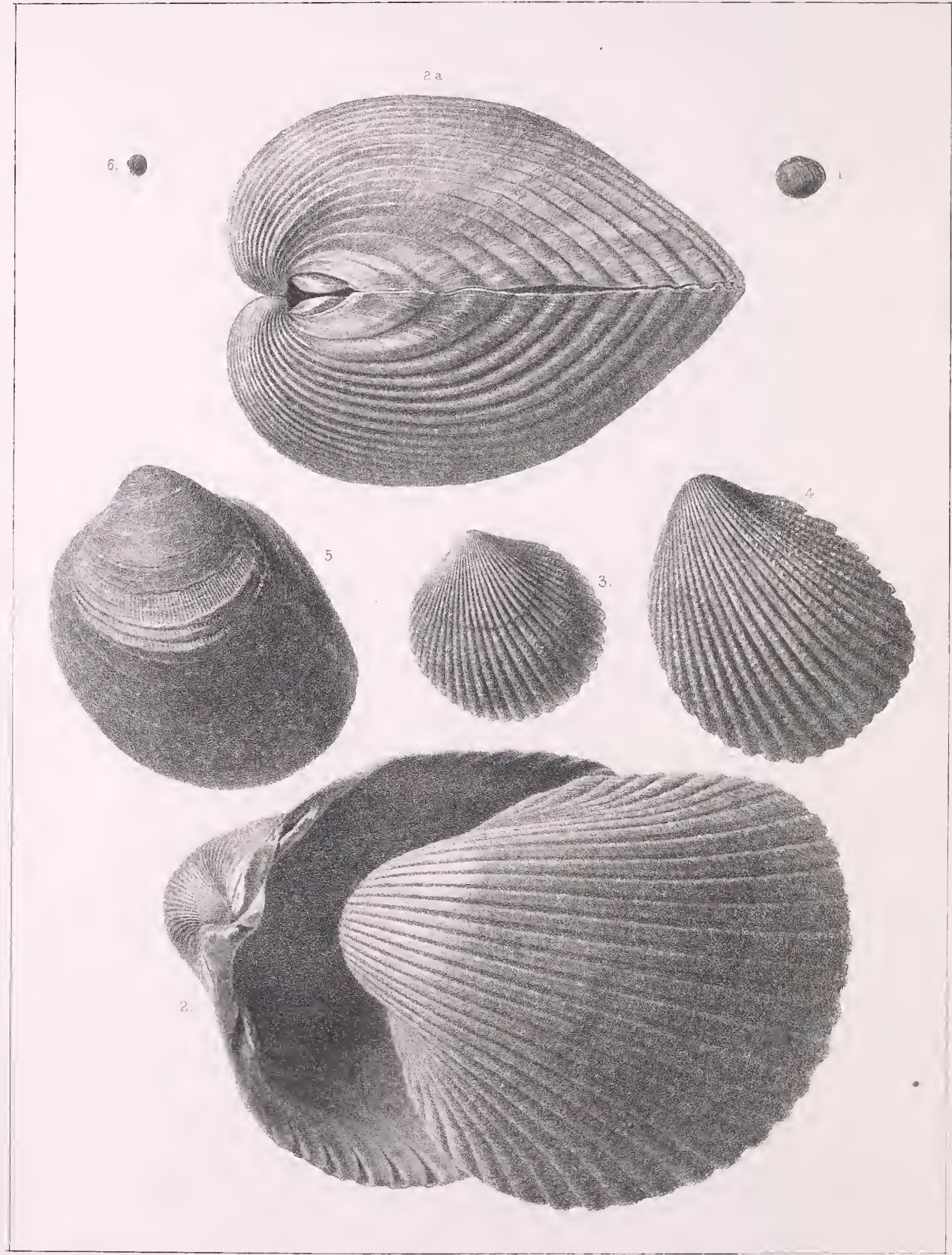

From nature by $\mathrm{C}$ G Haten

Charleston $\mathrm{S}_{0} \cdot \mathrm{C}_{2}$. 


\title{
POST-PLEIOCENE FOSSILS.
}

\author{
SOUTH-CAROLINA.
}

\author{
PLATE V. \\ C H A M I D E. - CARDIA D E. \\ C H A M I D $\mathbb{E}$.
}

Fig. 1. Chama aroinella. Natural size. Page 23.

$$
\text { C A R D I D AE. }
$$

Fig. 2. CARDIUM MagnUM. Natural size. Page 23.

" 2a. CARDIUM MAGNUM. Side view.

“ 3. CARDIUM MURICATUM. Natural size. Page 24.

"4. CARDIUM ISOCARDIA. Natural size. Page 25.

“ 5. LAEVICARDIUM SERRATUM. Page 25.

“ 6. CARDIUM MORTONI. Page 26.

This figure was accidentally blurred in the printing. 


\title{
POST-PLEIOCENE FOSSILS.
}

\author{
S O U T H - C AR O L I NA.
}

PLATE VI.

LUCINID E. C C CLADIDE.-CYPRINID E.—TELLINID E.

L U C I N I D E.

Fig. 1. LUCINA DIVARICATA. Exterior, left valve. Page 27.

" 2. LUCINA COSTATA. Natural size. Page 27.

" 3. LUCINA RADTANS. Natural size. Page 28.

“4. LUCINA TRISUlCATA. Natural size. Page 28.

" 5. LUCINA KIAWAHENSIS. Natural size. Page 29.

“ 6. LUCINA MULTILINEATA. Natural size. Page 29. LUCINA CRENULATA. Not figured. Page 30. MONTACUTA BOWMANI. See plate VII., fig. 2. Page 30.

- C Y C L A I D $\mathrm{D}$.

Fig. 7. CYRENA CAROLINIENSIS. Natural size. Page 31.

C Y P R I I D AE.

Fig. 8. CARDITd TRIDENTATA. Natural size. Page 31. CARDITA FLORIDANA. See Plate VII. Page 32.

" 9. ASTARTE LUNULATA. Natural size. Page 32.

T E L L I N I D A.

a-ji.

Fig. 10. MESODESMA CONCENTRICA. Natural size. Page 44. For others of this family, see plates VII. and VIII.

V E N E R D A.

Fia. 11. MERCENARIA VIOLACEA. Natural size. Page 33.

" $11 a$. MERCENARIA VIOLACEA. Lunule natural size.

" 12. MERCENARIA MORTONI. Natural size. Page 34.

" 12a. MERCENARIA MORTONI. Lunule.

" 13. MERCENARIA NOTATA. Natural size. Page 34.

" 14. CHIONE CANCELlata. Page 35.

" 15. CHIONE CIBRIRIA. Page 35. 


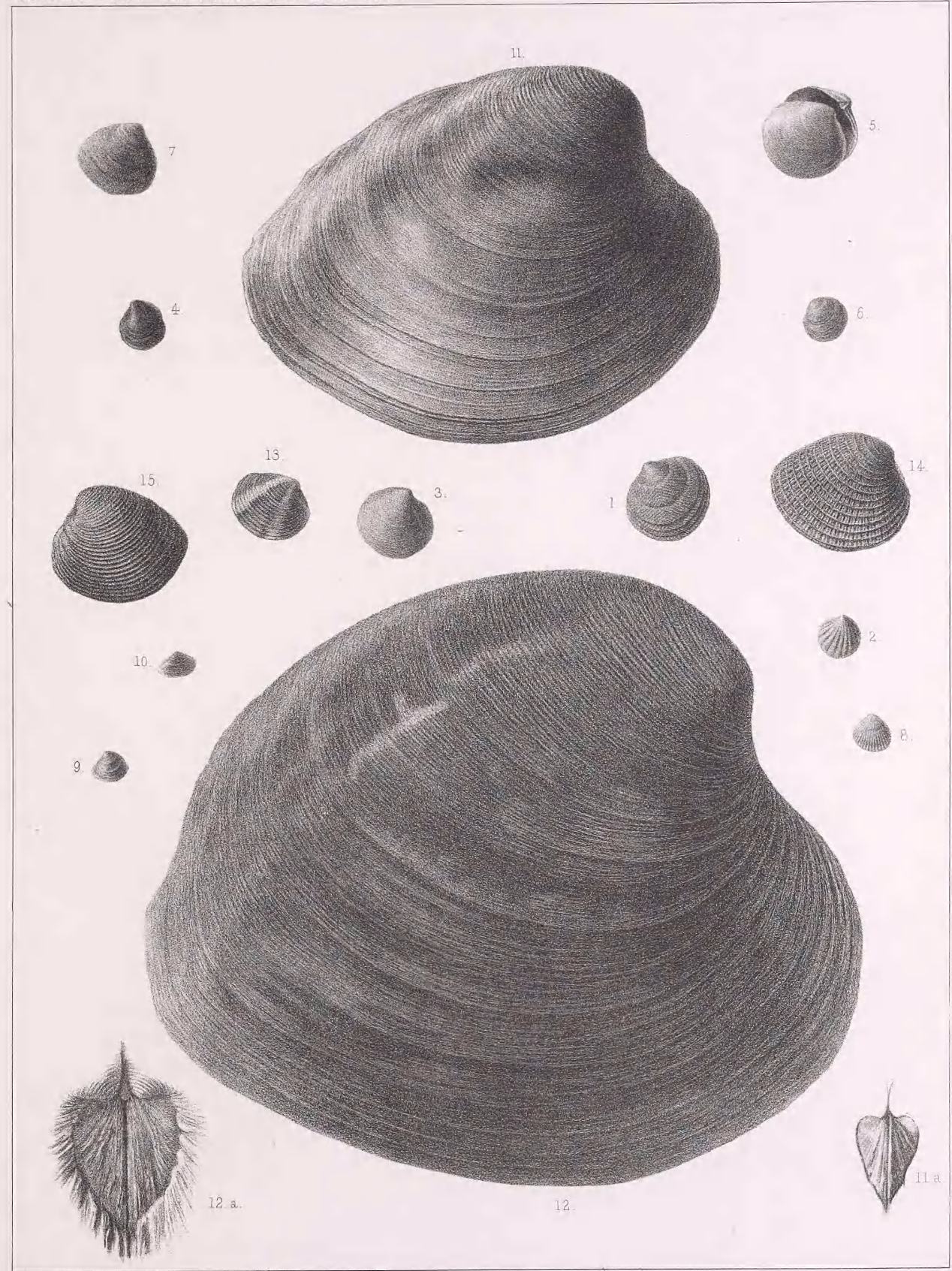

From nature by O. G. Platen, Charleston. So. Ca. 



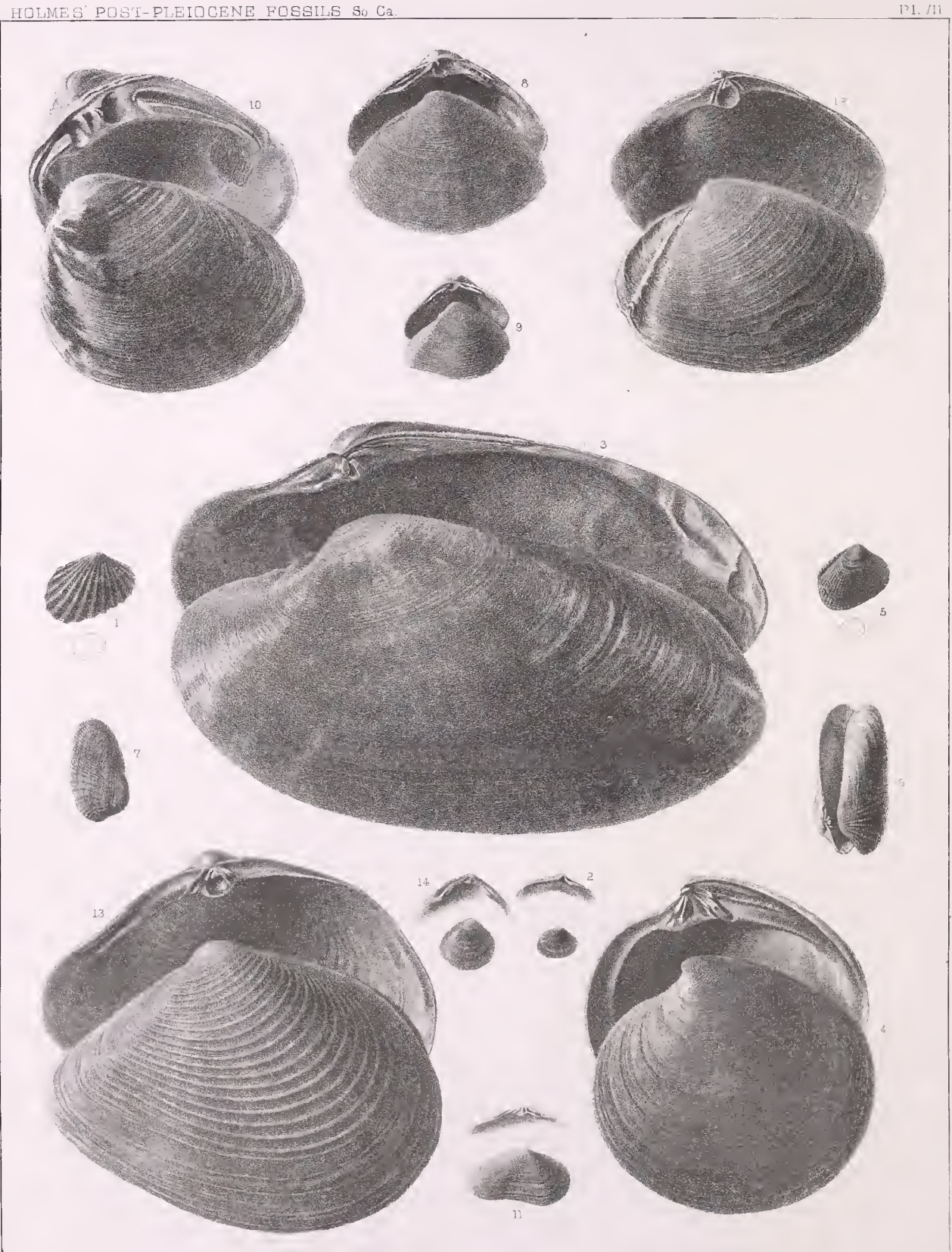

From Narure by C G Platen

Charleston. So. Ca. 


\title{
POST-PLEIOCENE FOSSILS.
}

\author{
SOUTH - C A ROLINA.
}

\section{PLATE VII.}

\section{CYPRINIDE.-LUCINIDE.-VENERIDE.-TELLINIDE.}

C Y P R I I D E.

Fig. 1. CARDITA FLORIDANA. Outline of natural size, and magnified figure. Page 32.

L U C I N I E.

Fig. 2. MONTACUTA BOWMANT. Page 30 .

VENERID $A$.

Fig. 3. CALLista GIGANTEA. Natural size. Page 36.

" 4. DOSTNIA CONCENTRICA. Natural size. Page 37.

“ 5. TAPES GRUS. Outline natural size, and magnified figure. Page 37.

$$
\text { P E T R I C O I D F. }
$$

Fig. 6. PETRICOLA PHOLADTFORMIS. Page 38.

“ 7. PETRICOLA DAC'TYLUS. Page 39.

\section{A C T R D E⿰.}

Fig. 8. MACTRA SIMILIS. Natural size. Page 39.

“ 9. MACTRA LATERALIS. Natural size. Page 40.

" 10. GNATHODON CUNEATUS. Page 41.

"11. MULINTA MILESII. Natural size. Page 42.

" 12. RAËTA LINEATA. Natural size. Page 42.

“ 13. RAËTA CANALICULATA. Natural size. Page 43.

\section{TELLINID $\mathbb{E}$.}

Fig. 14. TELLINA FLEXUOSA. Natural size. Page 44.

For others of this family, see Plate VI. and VIII. 


\title{
POST-PLEIOCENE FOSSILS.
}

\author{
S O U T H - C AR O L I NA.
}

PLATE VIII.

TE L LI N I D E. - S O LE N ID E. - M Y A C I D E.

TELLINID

Fig. 1. PERON FODERMa ALTERNATA. Natural sizo. Page 45.

“ 2. ANGUlus POLITA. Natural size. Page 45.

“ 3. PERON $\approx A$ TENTA. Natural size. Page 46.

“ 4. TEllina CAYEnNensis. Natural size. Page 47.

" 5. MaCOMA FUSCA. Natural size. Page 48.

“ 6. SERRULA VARIABILIS. Natural size. Page 49.

“ 7. ABRA EQUALIS. Natural size. Page 50.

“ 8. ABRA ANGULATA. Natural size. Page 50.

“9. SEMELE ORBICUlata. Natural size. Page 51.

“ 10. SEMELE TRANSVERsa. Natural size. Page 52. not of Day,

" 11. SEMELE RADIATA. Natural size. Page 52.

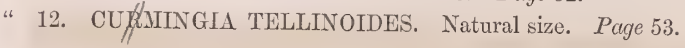

S OLENID A.

"13. ENSIS ENSIS. Natural size, one valve broken. Page 53.

“ 14. SILIQUARIA CARIB TELLIDORA LUNULATA. See Plate IX, Fig. 7. Page 47.

M Y A CID AE.

Fig. 15. MYA ARENARIA. Page 54.

"16. MYA SIMPLEX. Page 55.

" 17. CORBULA CONTRACTA. Page 56.

"18. SAXICAVA FRAGLILS. Page 57. 

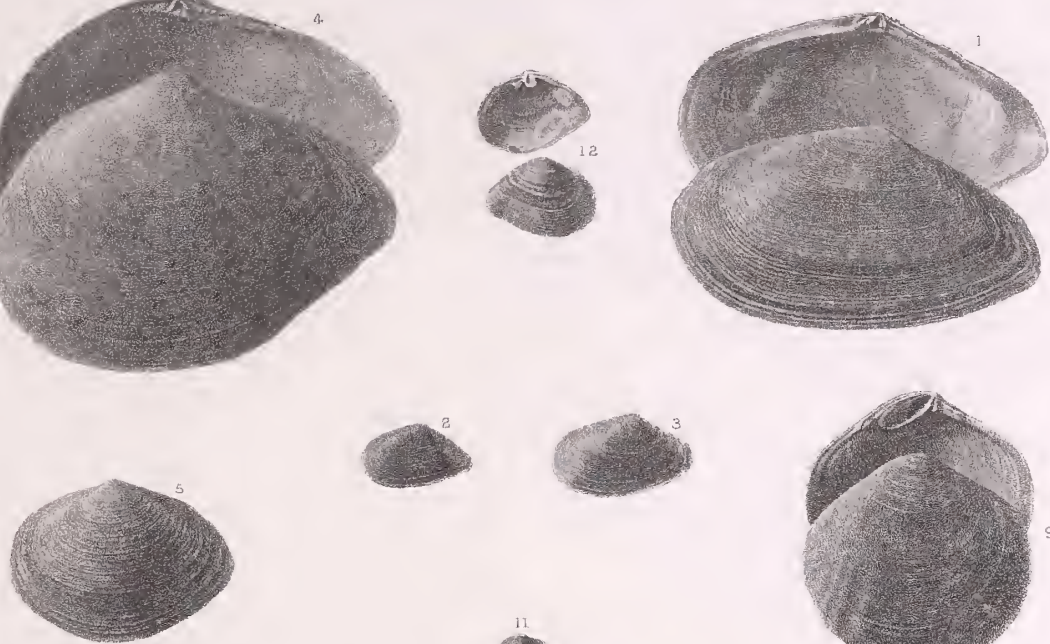

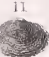
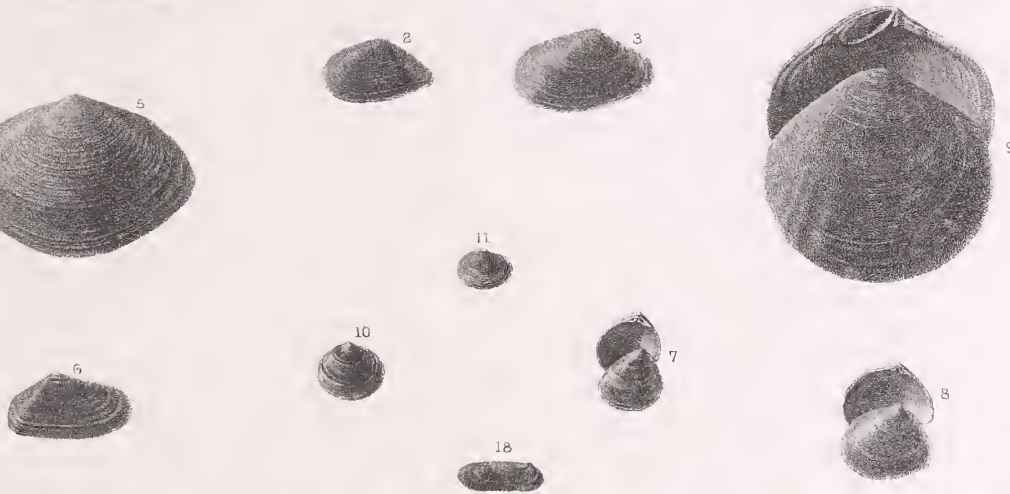

1,3
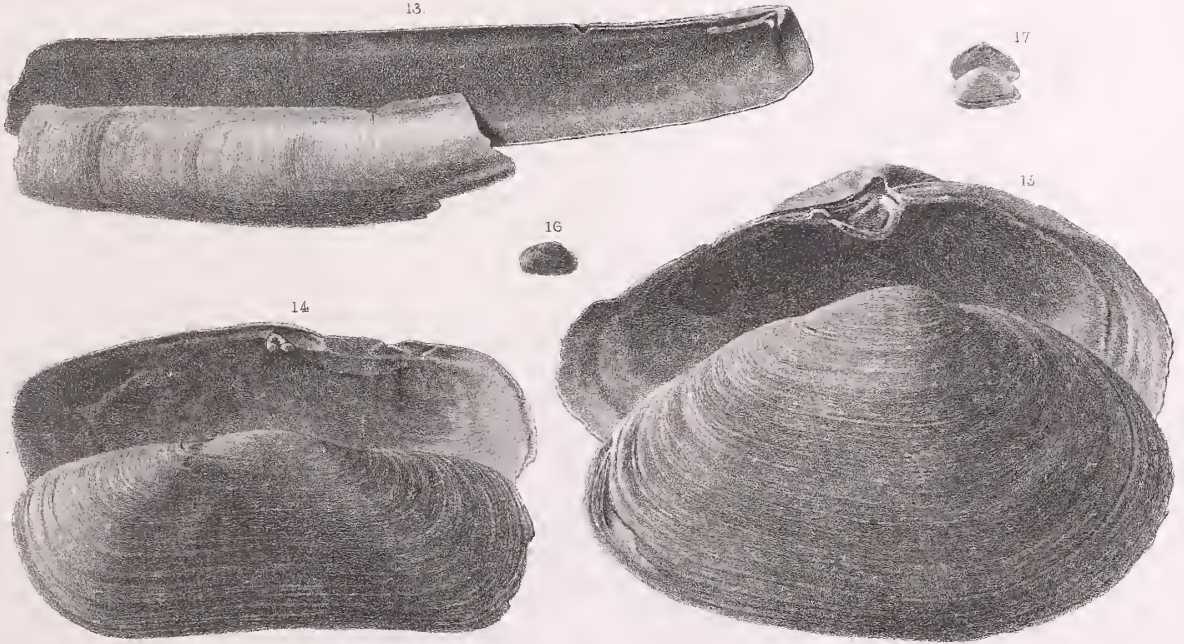

Prom Nature by C G Platen Charlestor So Ca 




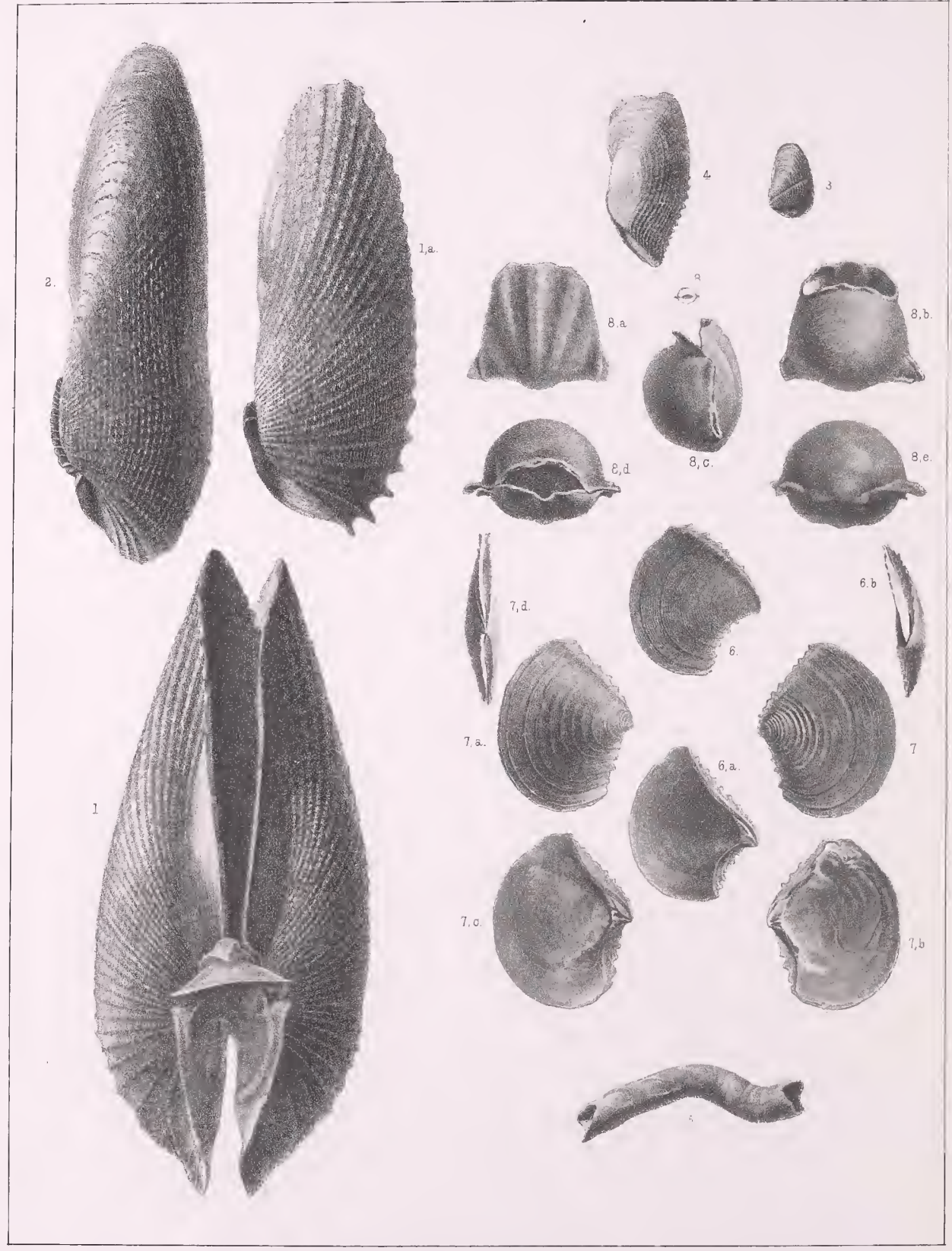

From nature by C G. Platen
Charleston, So. Ca. 


\title{
POST-PLEIOCENE FOSSILS.
}

\author{
S O U T H - C AR O L I NA.
}

PLATE IX.

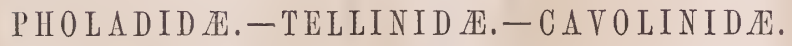

PHOLADID $A$.

Fig. 1. PHOLas Costata. Side view. Page 58.

" 1 a. Back view to show accessory valves.

"2. DACTYLINA OBLONGATA. Side view. Page 58.

“3. MARTESIA CUNEIFORMIS. Page 59.

.4. PHOLAS TRUNCATA. Page 57.

“ 5. XYLOTRYa Palmulata. Tube. Page 60.

TELLINID AE.

Fia. 6. TELLIDORA BURNETTII. A recent shell from California. Page 48.

" $6 a$. Interior of the same.

"6b. Side view.

“7. TELLIDORA LUnUladta. Fossil. Page 48.

"7a. Exterior.

"7b. Interior.

"7c. Interior.

“ $6 d$. Side view.

\section{CA V OLINID A.}

Fig. 8. CAVOLINA TUOMEYI. Page 60.

" $8 a$. View from above.

" $8 b$. View from below.

" $8 c$. Side view.

" 8d. Aperture.

" 8 . End view. 


\title{
POST-PLEIOCENE FOSSILS.
}

\author{
SOU T H - C A ROLINA.
}

PLATE X.
STROMBID $\mathbb{E}$. - MURICID E.-TRITONID E.-CANCELLARIID $\mathbb{E}$. STROMBID AE.

Fig. 1. STROMbUS PUGILIS. Natural Size. Page 61.

" 1a. Young Shell.

\author{
MURICID A.
}

Fig. 2. MUREX SPINACOSTATUS. Page 61.

TRITONID AE.

Fig. 3. EUPleUra CaUdata. Natural size. Page 62.

" 4. FASCIOLARIA GIGANTEA. Page 63.

" 5. FASCIOLARIA Distans. Page 63.

$$
\text { C A N C E L L A RIID } 2 \text {. }
$$

Fig. 6. CANCELlaria Reticulata. Page 64.

"7. CANCELLARIA VENUSTA. Page 64. 


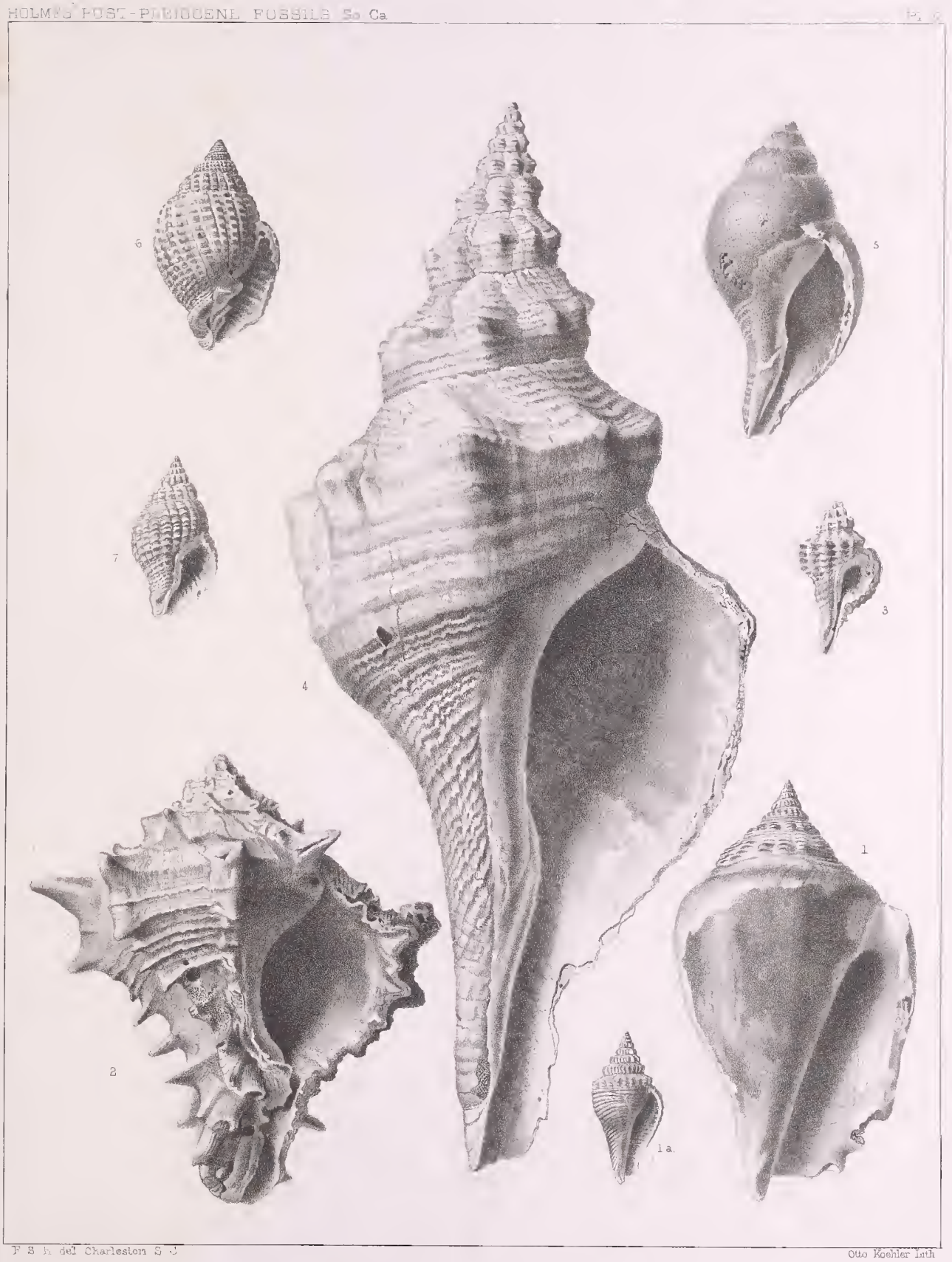






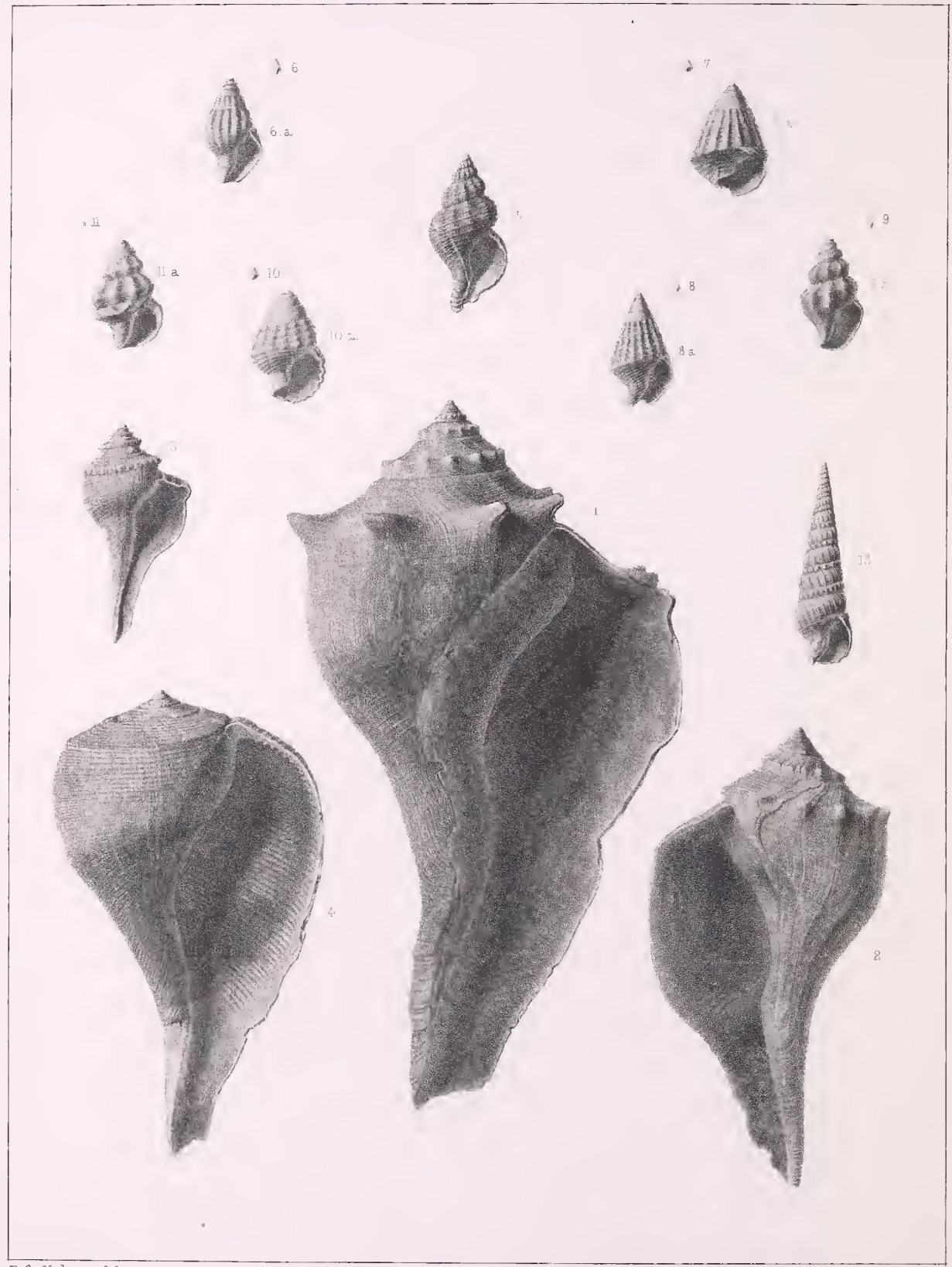




\title{
POST-PLEIOCENE FOSSILS.
}

\author{
S O UTH - C A R O L I N A.
}

\section{PLATE XI.}

II U R I C I D E. - B U C C I N I D $\mathbb{E}$.

M U R I C I D ※.

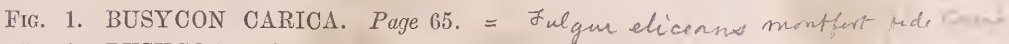

“ 2. BUSYCON PERVERSUM. Page 65.

“ 3. BUSYCON CANALICULATUM. Page 66.

“ 4. PYRULA PYRUM. Page 67.

“ 5. FUSUS CINEREUS. Page 68.

"6. FUSUS MINOR. Natural size. Page 68.

“ 6a. Magnified view.

“ 7. FUSUS CONUS. Natural size. Page 69.

“7a. Magnified viow.

“ 8. FUSUS CONUS. Variety, natural size. Page 69.

“ 8a. Magnified view.

" 9. FUSUS FILIFORMIS. Natural size. Page 69.

“9a. Magnified view.

“ 10. FUSUS BUluata. Natural size. Page 69.

" 10a. Magnified view.

“ 11. FUSUS RUDIS. Natural size. Page 70.

" 11a. Magnified view.

$$
\text { B U C C IN ID } \not \text {. }
$$

Fig. 12. TEREBRA DISLOCATUM. Page 70.

Notz.-For others of this family soe Plate XII. 


\title{
POST-PLEIOCENE FOSSILS.
}

\author{
S O U T H - C A R OLI NA.
}

PLATE XII.

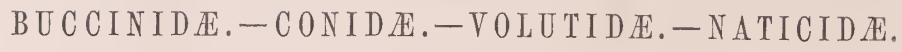

B U C C I N I D AE.

Fig. 1. BUCCINUM OBSoletum. Natural size. Page 71.

“ 2. BUCCINUM TRIVITtatum. Natural size. Page 72.

" 3. BUCCINUM ACUTUM. Natural size. Page 72.

“ 4. COLUMBella AVARA. Natural size. Page 73.

“ 5. COLUMbelia LUNATA. Natural size. Page 74.

" 5a. Magnified view.

" 6. COLUmbelia ORNata. Natural size. Page 74.

"6a. Magnified view.

“ 7. STREPHONA LITERATA. Natural size. Page 75.

" 8. OLIVA MUTICA. Natural size. Page 76.

C O NID E.

Fig. 9. PleUrotoma CERINUM. Natural size. Page 77.

"9a. Magnified view.

$$
\text { V O L U T ID A. }
$$

Fig. 10. VOLUTOMITRA. WANDOENSIS. Natural size. Page 77.

"10a. Magnified view.

" 11. VOLVARIA CANALICUldTA. Natural size. Page 78.

"11a. Magnified view.

“ 12. PORCEllana Limatula. Natural size. Page 78.

" 13. VOLVA ACICULARIS. Page 79.

N A T I C I D A.

Fig. 14. NATICA DUPLICATA. Natural size. Page 80.

“ 15. NATICA PUSILlA. Natural size. Page 80.

" 15a. Magnified view.

“ 16. CATINUS PERSPECTIVUS. Natural size. Page 81. 

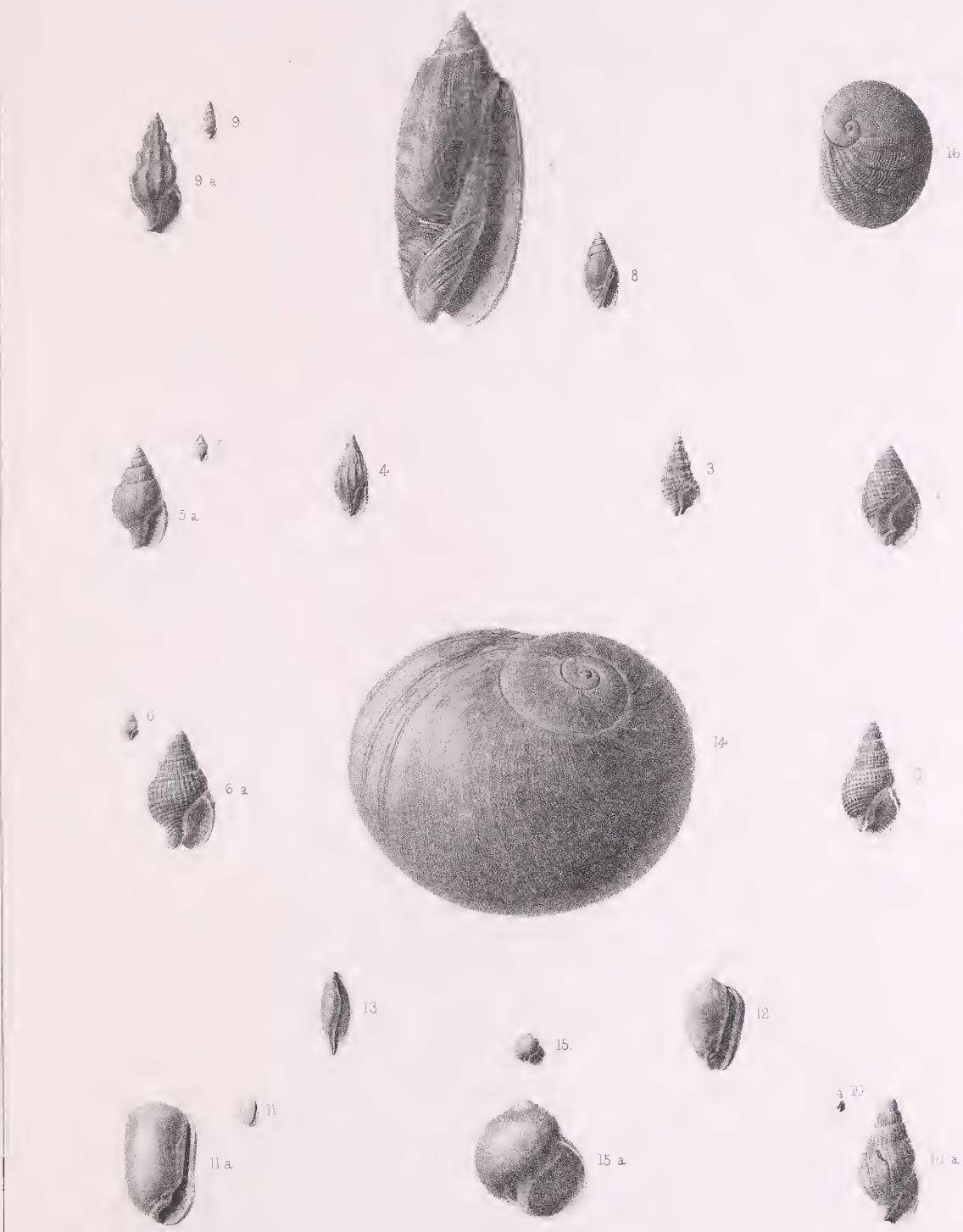

F S. Holmes, de

C G. Plater lith, Charleston 




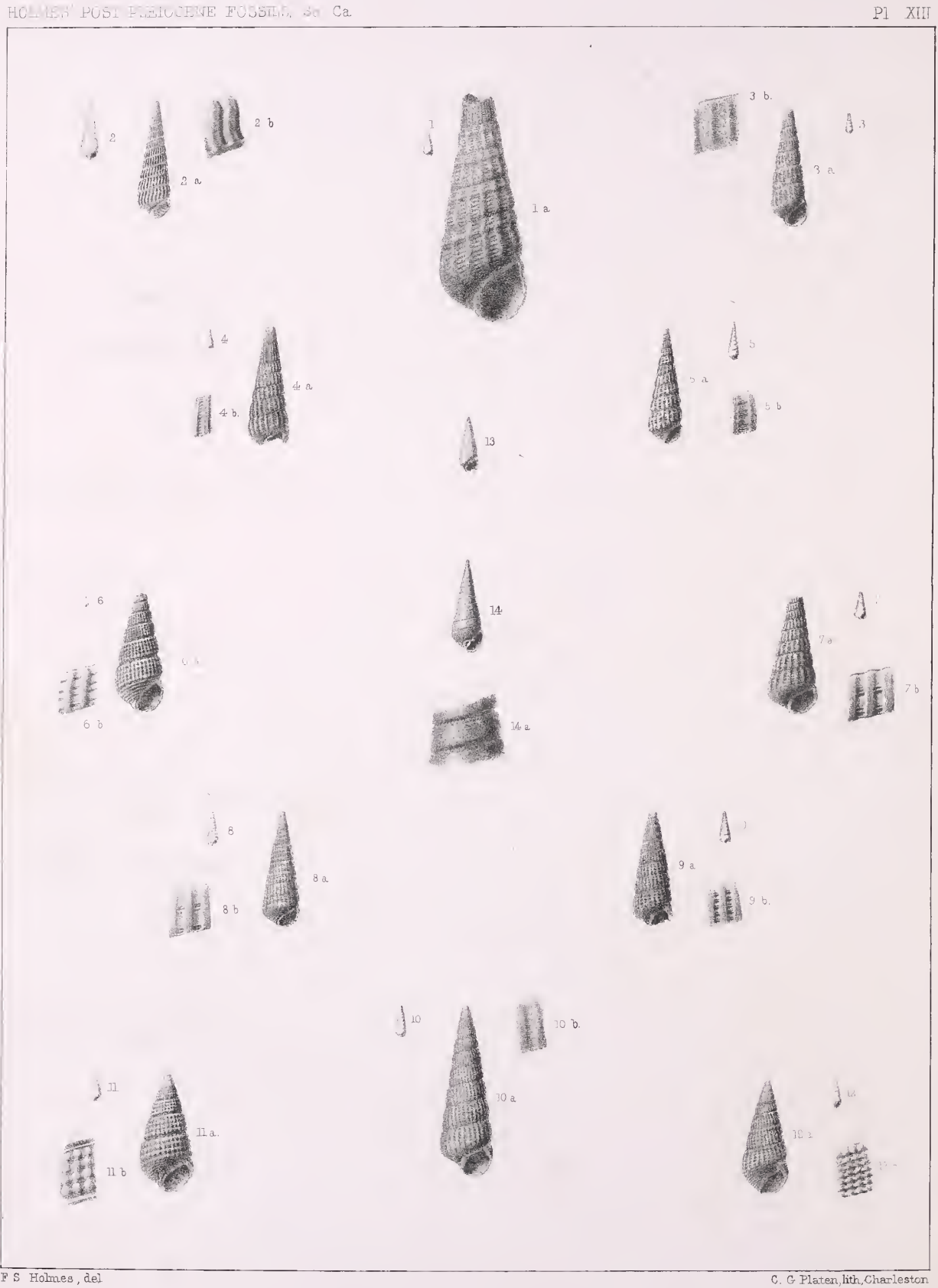




\title{
POST-PLEIOCENE FOSSILS.
}

\author{
S O U T H - CA R O L I N A.
}

PLATE XIII.

\section{P Y R A N I D E L L I D E.}

Frg. 1. TURbonilla SPEIRA. Natural size. Page 82.

" 1a. Magnified view.

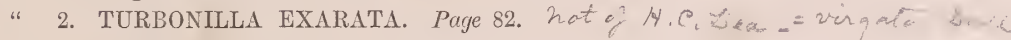

"2a. Magnified view.

"26. Magnified ribs and groove.

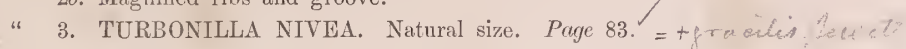

“ $3 a$. Magnified.

“3b. Magnified ribs and groove.

“ 4. TURBONILLA INTERRUPTA. Natural size. Page 83 . $\checkmark$ t mufo-eineta efc

“4a. Magnified view.

"46. Magnified ribs and groove.

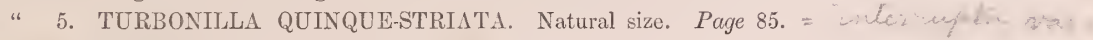

“ 5 . Magnified view.

"5b. Groove, ribs and revolving lines.

"6. TURBONILLA CANCELLATA. Natural size. Page 84. = reticulata ariv.

" 6 a. Maguified view.

“ 6b. Magnified ribs, grooves and revolving lines.

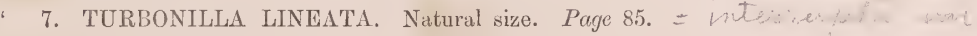

“ 7a. Magnified view.

“ 7b. Magnified ribs and grooves.

" 8. TURBONILla SUBULATA. Natural size. Page 85. weta vepta ec

" $8 a$. Magnified view.

" 8b. Magnified ribs and grooves.

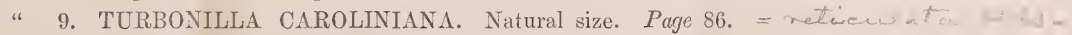

“9a. Magnified view.

“9b. Magnified ribs and grooves.

" 10. TURBONILLA ACICULA. Natural size. Page $86 .=47 \ldots+\infty$

“ $10 a$. Magnified view.

"10b. Magnified ribs and grooves.

" 11. ODOSTOMIA GRANUlatus. Natural size. Page 86

" 11a. Magnified view.

" 11b. Magnified ribs.

“ 12. TURbonilla SUb-CORONATA. Natural size. Page 87.

"12a. Magnified view.

" 12b. Magnified whorl, with coronated margin.

" 13. EULIMA EBOREA. Natural size. Page 88.

“ 14. OBELISCUS CRENUlatUS. Natural size. Page 88.

“ 14a. Crenulated suture magnified. 


\title{
POST-PLEIOCENE FOSSILS.
}

\author{
S O U T H - C A R O L I N A.
}

\author{
$\underline{-10}$ \\ PLATE XIV.

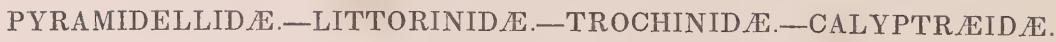 \\ CHITONIDÆ.-PLANORBID A.-MELAMPIDÆ. \\ P Y RA MIDELLID Æ. \\ Fig. 1. SCALARIA Clathrus. Natural size. Page 89. \\ "2. SCALARIA ANGUlata. Natural size. Page 89. \\ “ 3. SCALARIA LINEATA. Natural size. Page 90. \\ “4. SCALARIA MULTistriata. Natural size. Page 90. \\ LITT O RINID $\mathbb{E}$. \\ Fig. 5. LiTTORINA IRRoRATA. Natural size. Page 91. \\ “ 6. ARCHITECTONICA GEMma. Natural size. Page 92. \\ "6a. Magnified. \\ " 6b. Magnified outline.
}

TR O C HIN ID \&.

Fig. 7. ANGARIA CRASSA. Natural size. Page 92.

" 7a. Magnified view from above.

" 7b. Outline, front viewv.

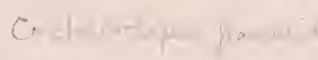

4. A. AEEORBIS-NAUTHEFORMES. Natural size. Page 93.

" 8 . Magnified view from above.

" 8b. Magnified outline of shell.

“ 9. COCHLIOLEPIS PARASITICUS. Natural size. Page 93.

" $9 a$. Magnified view.

"9b. Magnified outline of shell.

\section{A L Y P T R A I D Æ.}

Fig. 10. Fissurella Alternata. Natural size. Paye 94.

" 11. CRYPTA FORNICATA. Natural size. Page 95.

" 12. CRYPTA ACULEATA. Natural size. Page 95.

\section{H I T ON I D A.}

Fig. 13. CHITON APICUlatus. Natural size, side view. Page 96.

". 13a. Vierv from above.

“ 13b. Magnified view from above.

“ 13c. Magnified view of series of elevated points.

$$
\text { PLANORBID E. }
$$

Fig. 14. PLANORBIS LentUS. Imperfect shell. Page 97.

$$
\text { MELA M P I D } 2 \text {. }
$$

Fig. 15. MELaMrus BIDentatus. Natural size. Page 97. “ 15a. Magnified. 


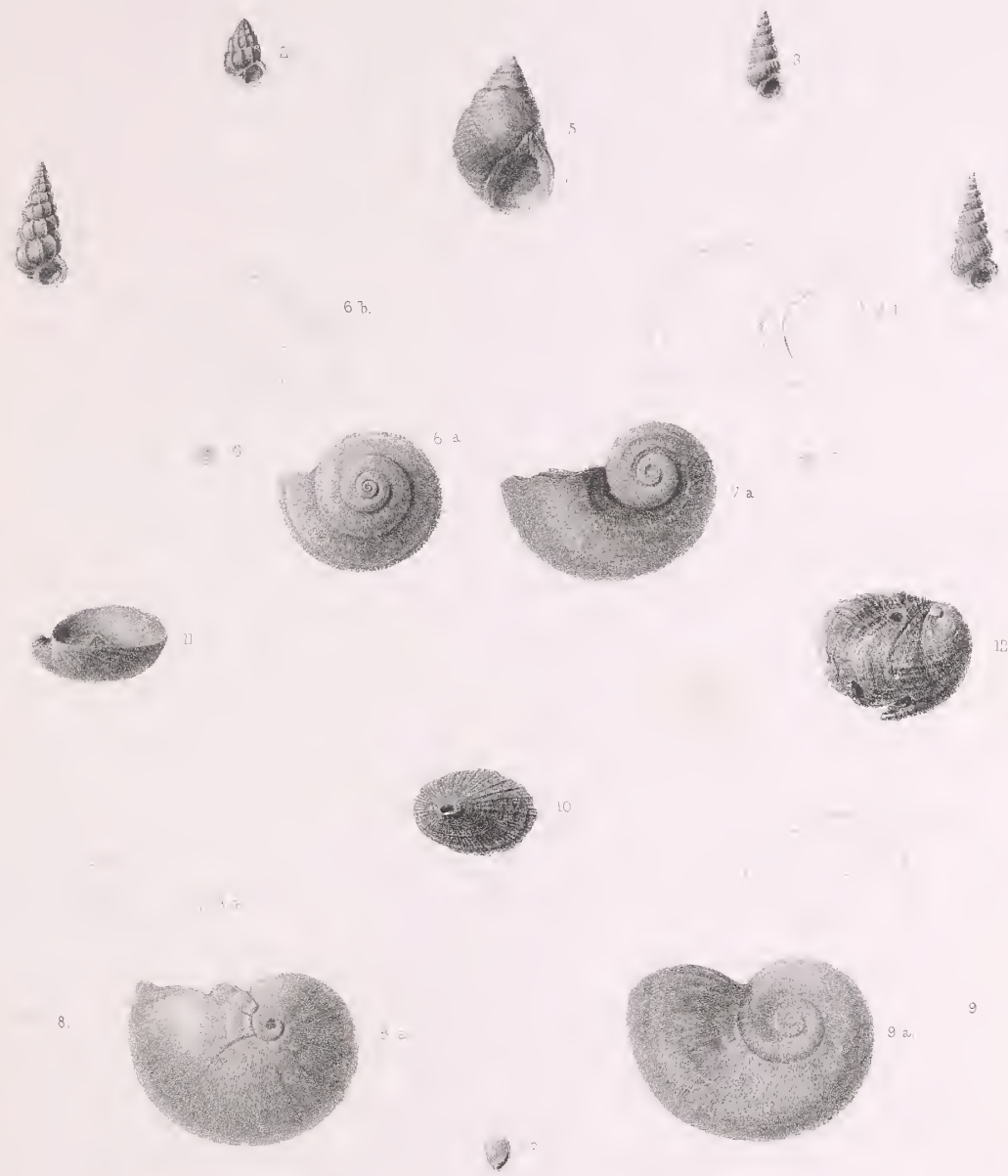

$13 a>-13$ (renting

130 




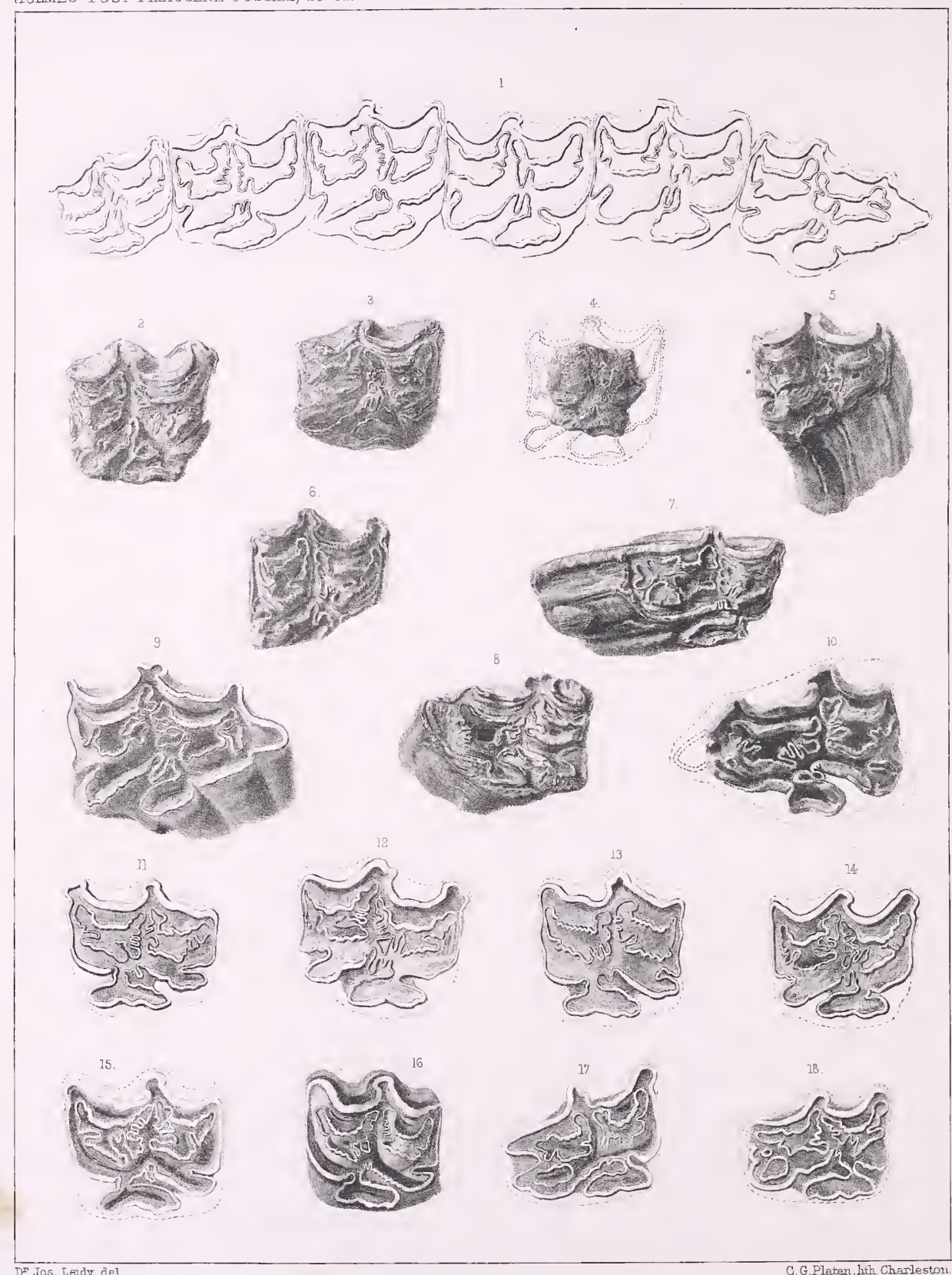




\title{
POST-PLEIOCENE FOSSILS.
}

\author{
S OU TH - C A R O L I NA.
}

\section{PLATE XV.}

\section{SOLIPEDIA.}

Fra. 1. Series of upper molar teeth, right side, of the domestic Horse. Triturating surfaces, exhibiting the course of the enamel folding. Page 103.

Fras. 2-5. Upper molar teeth of EQUUS COMPLICATUS, from the Post-Pleiocene deposits of Ashley river, S. C. Page 103.

“ 6. Upper molar of EQUUS FRATERNUS, from Doctor's Swamp, John's Island. Page 103.

“ 7. Last upper molar, EQUUS COMPLICATUS, from Ashley river. Page 103.

“ 8. First upper molar, E. FRATERNUS, from Post-Pleiocene of S. Carolina. Page 104.

“ 9. First upper molar, E. COMPLICATUS, from Illinois Bluffs, Dr. Shumard's collection. Page 104. Figs. 11--15. Upper molars, E. COMPLICATUS, from Natchez ravines, Miss. Page 103.

Fig. 16. Upper molar, E. FRATERNUS, from North Carolina. Prof. Emmon's collection. Page 104. Figs. 17, 18. Last upper molars, E. FRATERNUS, from Natchez Islands. Page 104. 


\title{
POST-PLEIOCENE FOSSILS.
}

\author{
S O U T H - C A R O L I N A.
}

PLATE XVI.

\section{S OLIPEDIA.}

Figs. 19-22. Lower molar teeth of EQUUS COMPLICATUS and E. FRATERNUS, from the PostPleiocene deposits of Ashley river. Page 112.

Fig. 23. Lower molar of E. FRATERNUS, from the excavation of the Brunswick Canal, Georgia. J. H. Couper, Esq. Page 104.

Frgs. 24--26. Lower molars, E. COMPLICATUS, from the Natchez ravines. Page 103.

FIG. 27. Lower molar, E. FRATERNUS, from vicinity of Natchez. Page 103.

"28. Outer view of the specimen represented in figure 16, Plate XV. Page 104.

"29. Outer view of the specimen represented in figure 3 , Plate XV.

Figs. 30, 31. Lower and upper molar of E. COMPLICATUS, from the Natchez ravines.

Fig. 32. Upper molar of HIPPOTHERIUM VENUSTUM, from the Post-Pleiocene beds of the $\Lambda$ shley river. Magnified two diameters. Page 105.

" $32 a$ Inner view of the same specimen, of the natural size.

Fig. 33. Upper molar, HIPPOTHERIUM VENUSTUM, from the Ashley river beds. Natural size. Page 105.

Fra. $33 a$. Outer view of the same specimen. 


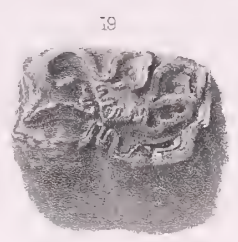

20

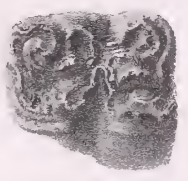

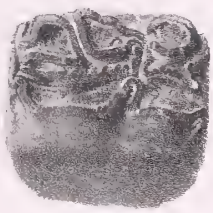

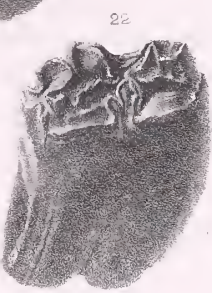

(5)
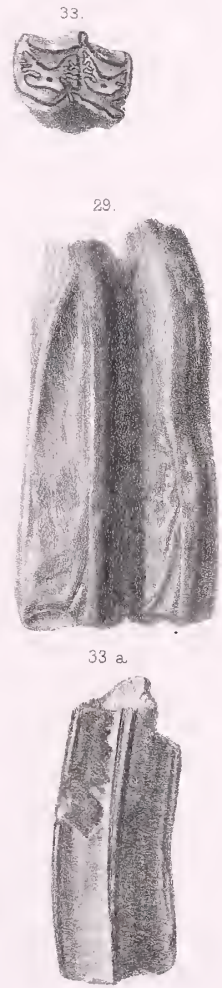


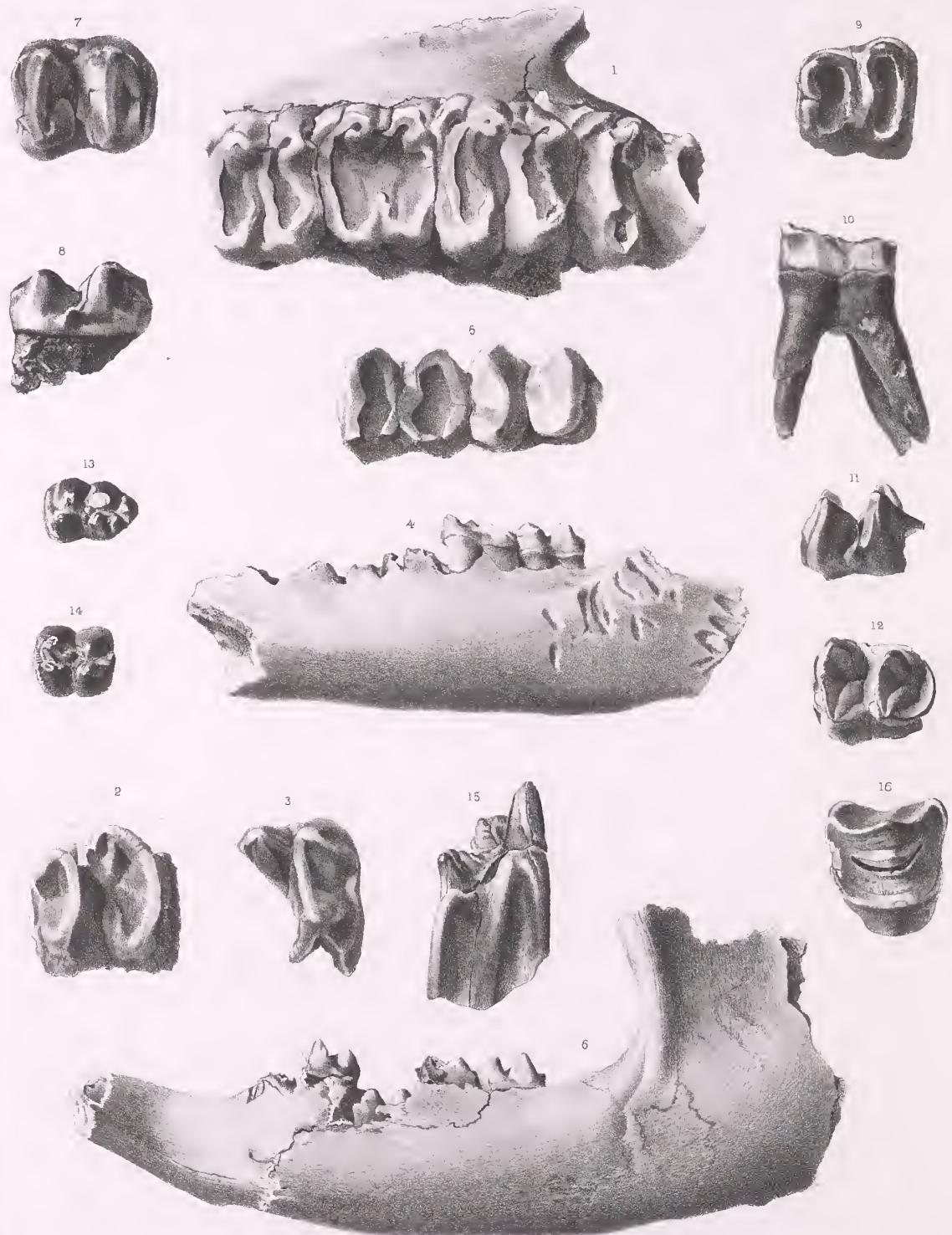


\title{
POST-PLEIOCENE FOSSILS.
}

\author{
S O U T H - CA R OLI NA.
}

\section{PLATE XVII.}

\section{PACHYDERM A TA.-RUMINANTIA.}

Fig. 1. TAPIRUS AMERICANUS FOSSILIS. Fragments of the upper jaw, left side, with the back form molar teeth. From Texas. Page 106.

Figs. 2, 3. TAPIRUS AMERICANUS FOSSILIS. Portions of the crowns of upper molar teeth from the Ashley river deposits. Page 106.

Fig. 4. TAPIRUS HAYSII. Fragment of the left side of the lower jaw, with the back two molar teeth. 'One-half the natural size. From Adams Co., Mississippi. Page 107.

“5. Triturating surfaces of the teeth of the former specimen. Of the natural size.

“ 6. TAPIRUS AMERICANUS FOSSILIS. Left side of the lower jaw. Reduced one-half. From Texas.

Figs. 7, 8. TAPIRUS HAYSII. Lower molar tooth. From Big-bone-lick, Kentucky. Page 106.

“ 9, 10. TAPIRUS HAYSII. Lower molar tooth. From Indiana. Page 108.

" 11, 12. TAPIRUS AMERICANUS FOSSILIS. Lower molar tooth, fram the Ashley river deposits. Page 106.

“ 13, 14. DICOTYLES FOSSILIS. Two baek lower molar teeth, from the Ashley deposits. Page 108.

“ 15, 16. BISON LATIFRONS. Last upper premolar, from the Ashley deposits. Page 109. 


\section{POST-PLEIOCENE FOSSILS. \\ S O UTH - C A R O L I N A.}

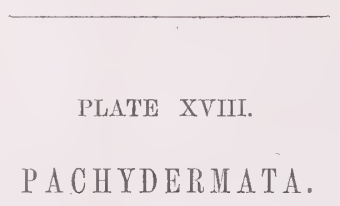

Fir. 1. ILEPHAS AMERICANUS. An inferior back molar tooth. From Texas. Page 108. 


\section{Hig 1}

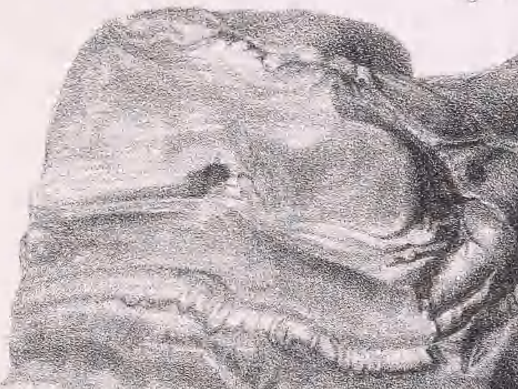

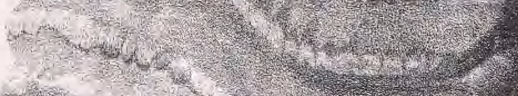

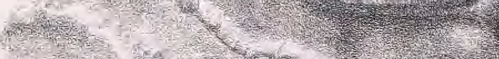

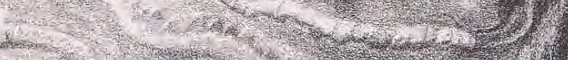

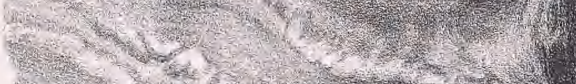

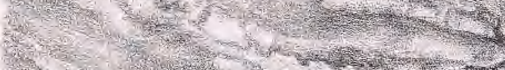

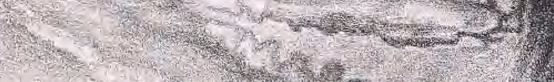

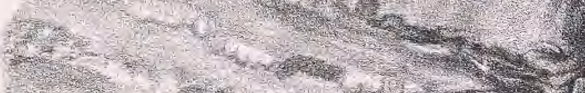
7. 3 .

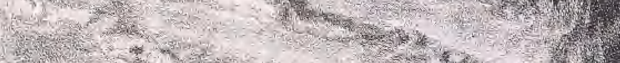

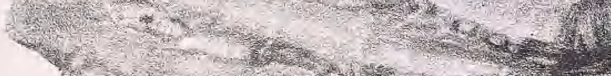

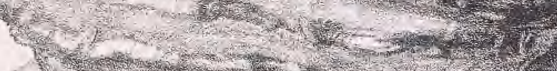
Hon

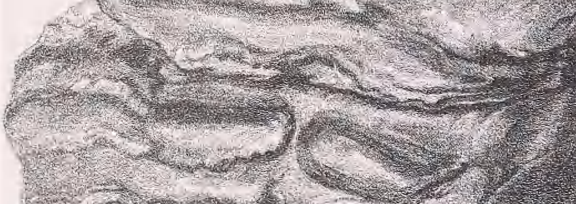

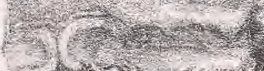

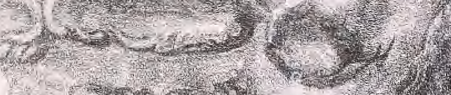

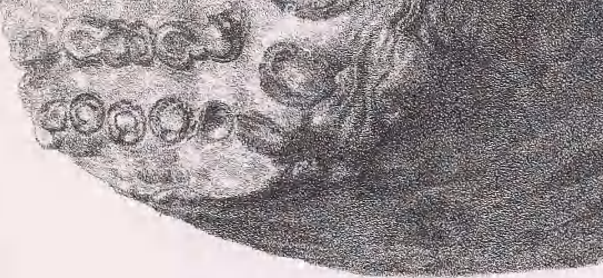
2.
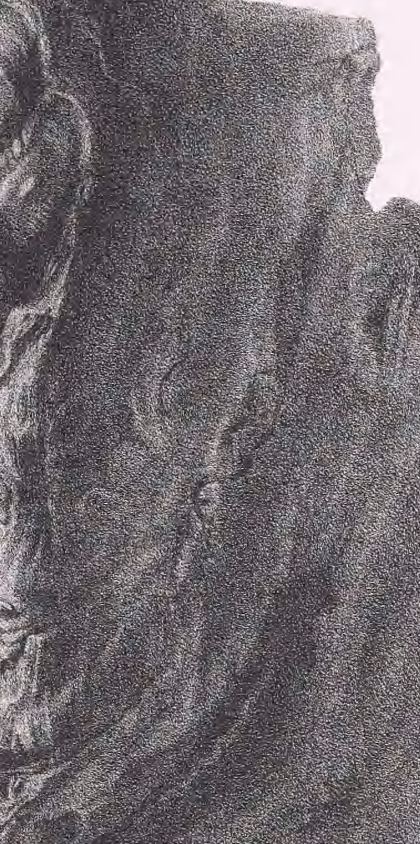

\section{(xis:}
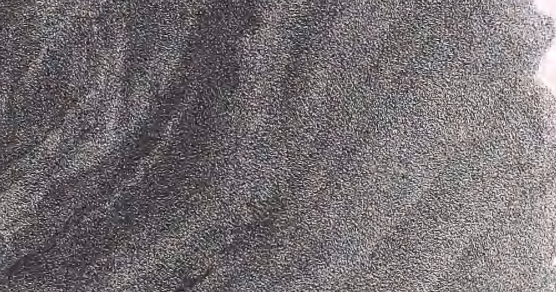



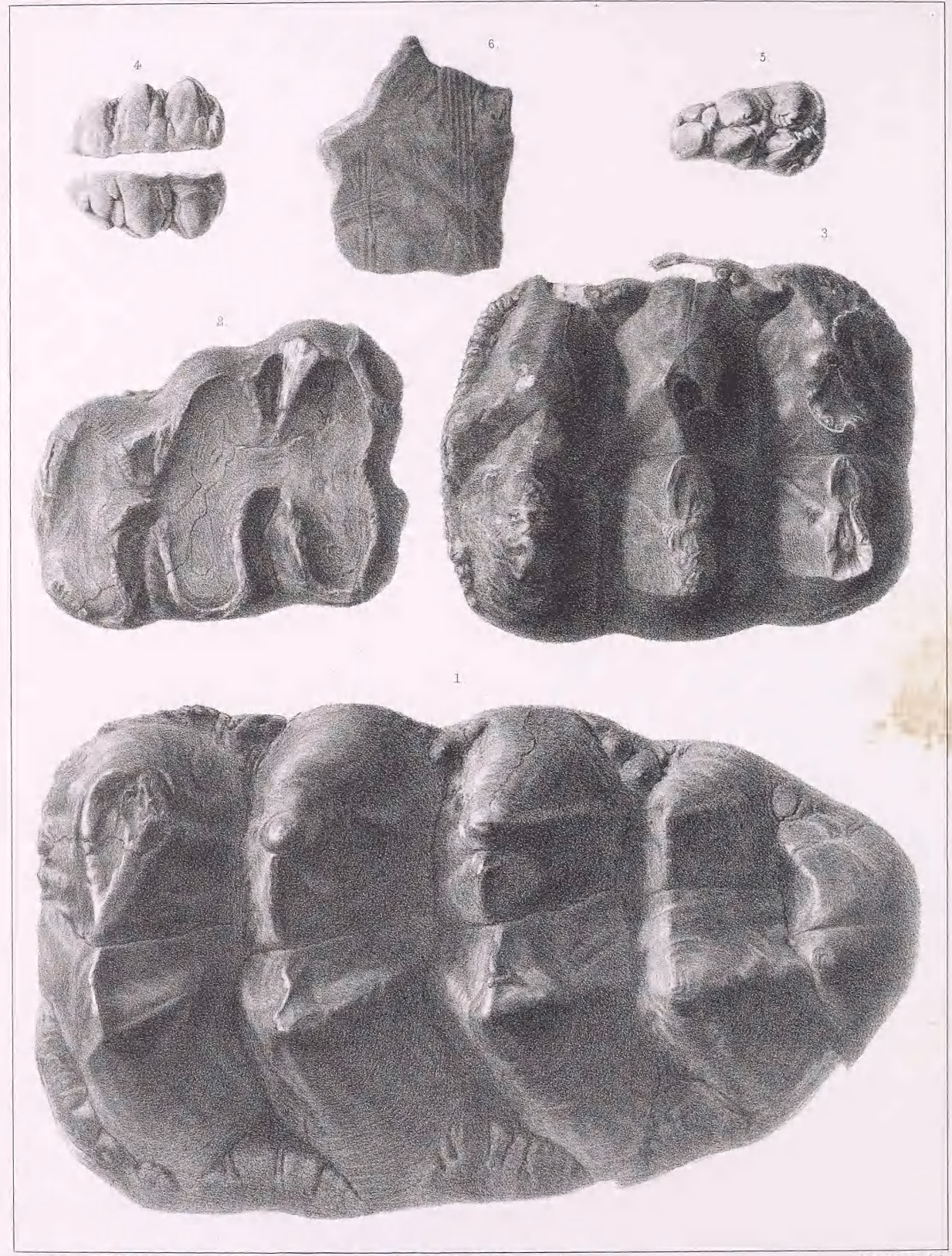

F s. Holmes, dei. 


\title{
POST-PLEIOCENE FOSSILS.
}

\author{
S O U T H - CA R O L I N A.
}

\section{PLATE XIX}

\section{P ACHYDER II A TA.}

Figs. 1, 2, 3. MASTODON OHIOTICUS. From Dr. L. F. Klipstein, Christ Church. Page 108.

Fig. 1. The sixth or last molar tooth. View of the triturating surface. From the same.

"2. Fifth molar tooth; triturating surface. From the same.

"3. Fourth molar tooth; triturating surface, much worn. From the same.

“4. SUS SCROFA. Outer and inner views of the last lower molar tooth. From the Ashley deposits. Page 109.

“ 5. Triturating surface of the same specimen.

“6. Fragment of INDIAN POTTERY. From Dr. Klipstein, Christ Church. See appendix to this Volume. 


\section{POST-PLEIOCENE FOSSILS.}

S OUTH-CA R O L I N A.

\section{PLATE XX.}

\section{R U MINANTIA_- EDENTATA}

Figs. 1, 2, 3. CERVUS VIRGINIANUS. Fragments of antlers from the Ashley deposits. Page 109. Fig. 4. Last molar tooth, outer view.

"4a. Triturating surface of the same.

" 5. BOS TAURUS. Last lower molar tooth, inner view. From the Ashley deposits. Page 110.

" 5 a. Triturating surface of the same.

" 6. OVIS AMIION. Lower molar tooth, inner view. From the Ashley deposits. Page 110.

" $6 a$. Triturating surface of the same.

" 9. Last lower temporary molar, outer view.

" 9 a. Tritutary surface of the same.

Figs. 7, 7a 7b. MYLODON HARLANI. Three views of a fragment of a lower molar tooth. Page 111.

“ 8, 8a. MEGATHERIUM MIRABILE. Two views of a fragment of a lower molar tooth. Page 111. 

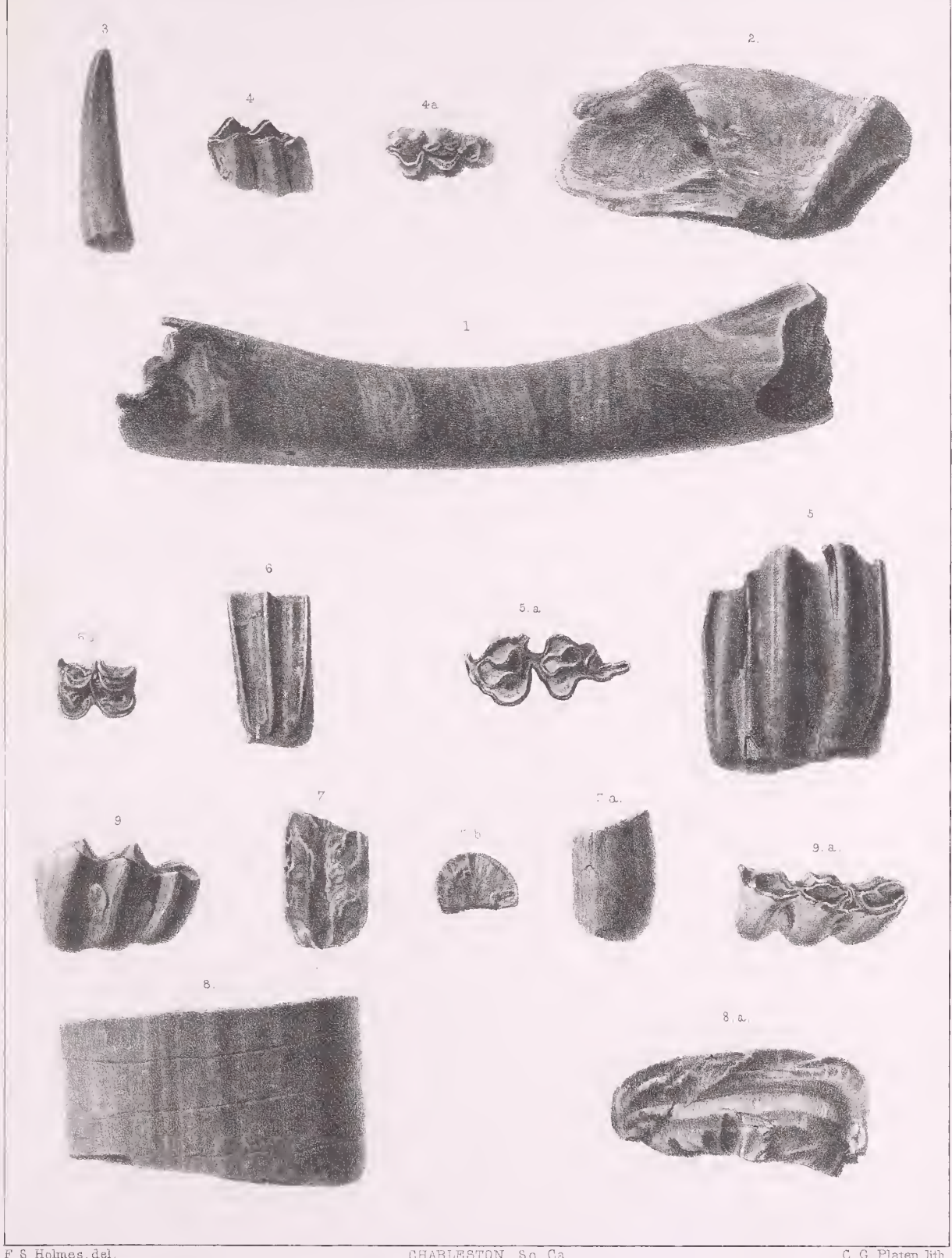

2.

F \& Folmes, del

CHARIRSTON SO CA

C G Platen, lith 



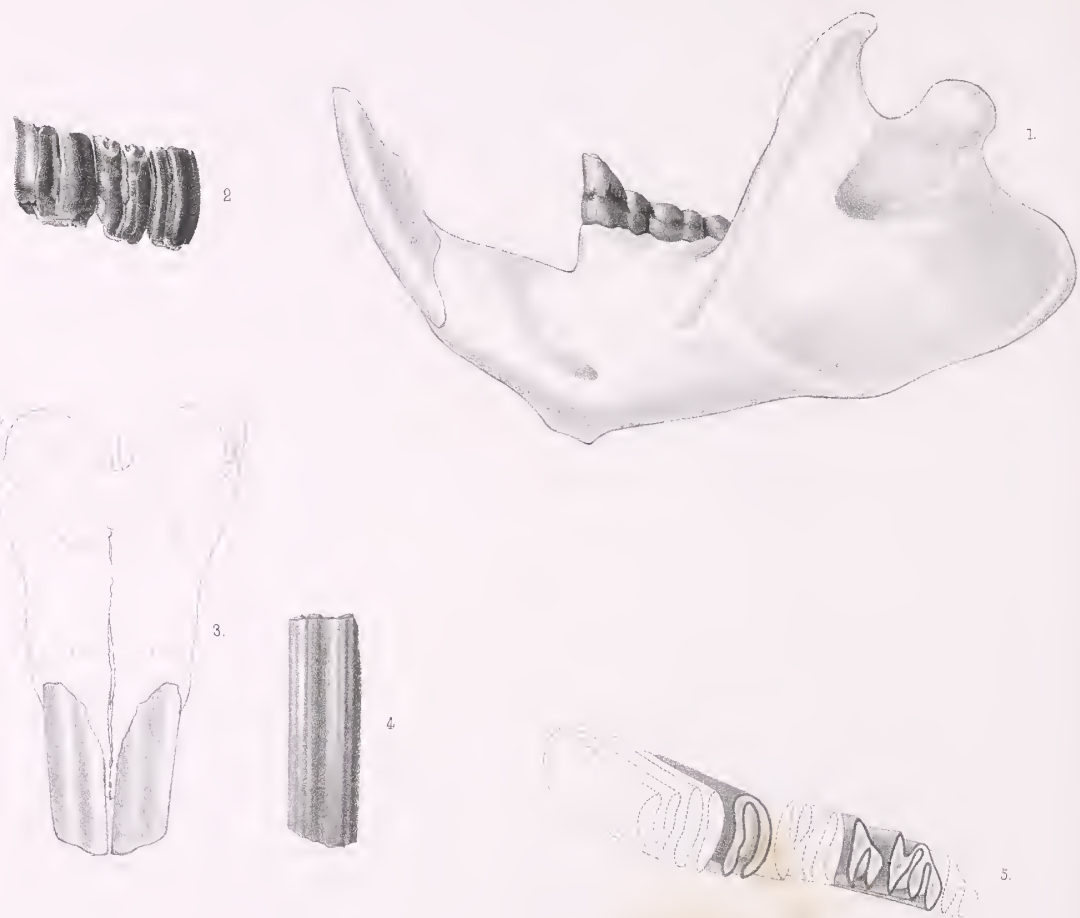

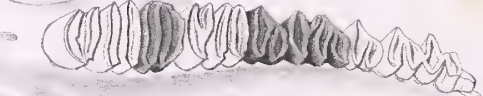




\section{POST-PLEIOCENE FOSSILS.}

S O U T H - C A R O L I N A.

\section{PLATE XXI.}

FIG. 1. CASTOR CANADENSIS. Left lower maxillary bone. From a recent specimen.

" 2. CASTOR CANADENSIS. Lower molar teeth. Fossils from the Ashley beds. Page 111.

" 3. HYDROCHERUS CAPYBARA. Front view of upper jaw and incisors. From a recent skull.

“4. HYDROCHERUS AESOPI, Leidy. Fragment of an upper incisor. Fossil from Ashley river. Page 112.

“ 5. HYDROCHERUS ESOPI, Leidy. A series of lower molars; the shaded parts indicating the fossil specimens from the Ashley beds.

“ 6. HYDROCHCERUS, recent. Left lower maxillary bone. The shaded teeth indicating the position of fig. 5 . 


\title{
POST-PLEIOCENE FOSSILS.
}

\author{
S O U T H - C A R O L I N A.
}

\section{PLATE XXII.}

FIG. 1. LEPUS SYLVATICUS, or common Gray Rabbit. Left lower maxillary bone. The shaded teeth indicate the fossils found in the Ashley beds. Page 113.

" 2. FIBER ZIBE'THICUS, or Musk-Rat. Fragiment of right lower maxillary bone, with teeth. From the Ashley beds. The restored outline of the jaw from a recent specimen. Page 113.

Figs. 3, 4. Incisors of the same, from the Ashley.

Fig. 3. CASTOROIDES OHIOENSIS, from Shawnetown, Illinois. Side view of an upper incisor. Specimen in the collection of the Academy of Natural Sciences, Philadelphia. Page 114.

6. Small fragment of an incisor of the same animal from the Asliley beds.

FIGS. 7, 8. Fragments of molar teeth from the saine locality.

FIG. 9. Series of lower molars, in outline, from a specimen, found near Memphis, Tennessee, and now in the Cabinet of the Academy. 

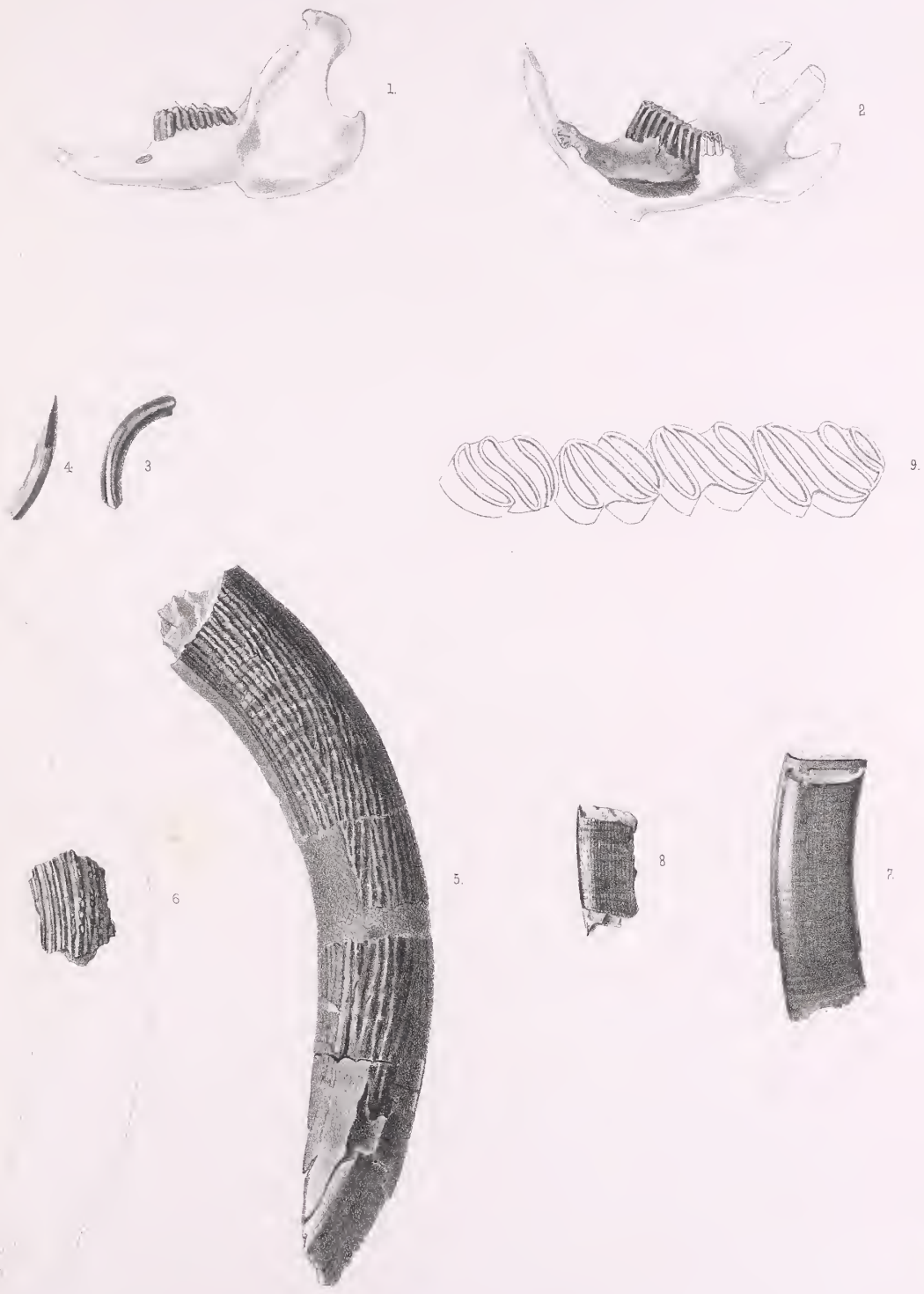

Charleston, So $\mathrm{Ca}$. 



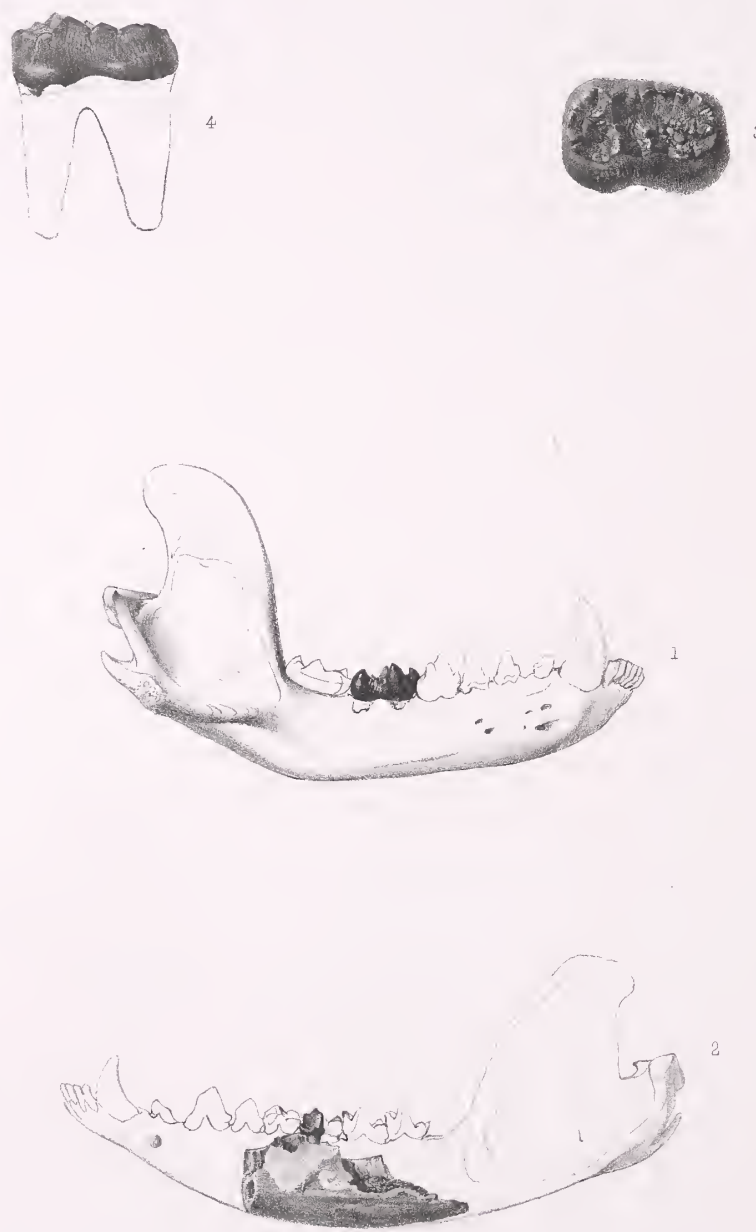


\section{POST-PLEIOCENE FOSSILS.}

S OU TH-CA R O L I NA.

\section{PLATE XXIII.}

FIG. 1. PROCYON LOTOR, the Raccoon. Right lower maxillary bone. The shaded penultimate molar indicates a fossil from the Ashley beds. Page 115.

“ 2. DIDELPHYS VIRGINIANA, the Opossum. Left lower maxillary bone The shaded portion indicates a fossil fragment from John's Island. Page 116.

“ 3. ARCTODUS PRISTINUS, Leidy. Penultimate lower molar. View of the triturating surface.

"4. Lateral view of the same specimen, with the fangs restored in outline. Page 115. 


\title{
POST-PLEIOCENE FOSSILS.
}

\author{
S O UTH - CAR OL INA.
}

\section{PLATE XXIV.}

Fig. 1. CANIS FAMILIARIS, the Dog. Anterior portion of the skull. The two shaded molar teeth indicate fossils from the Ashley deposit. Page 116.

" 2. Astragalus of the Deer, from the Ashley beds.

" 3. Phalanx undetermined, from the Ashley beds.

" 4. Phalanx undetermined, from the Aslley beds.

“ 5. MANATUS ANTIQUUS, Leidy. Inner view of an upper molar. From the Ashley beds

" 6. View of the triturating surface of the same specimen. Page 116.

"7. Outer view of the same.

“ 8. PHYSETER ANTIQUUS, Leidy, ancient sperm whale. Lower tooth. Fossil from the Ashley beds. Puge 117.

" 9. Tooth similar to the above, but of more recent appearance; found in the Charleston beds. 

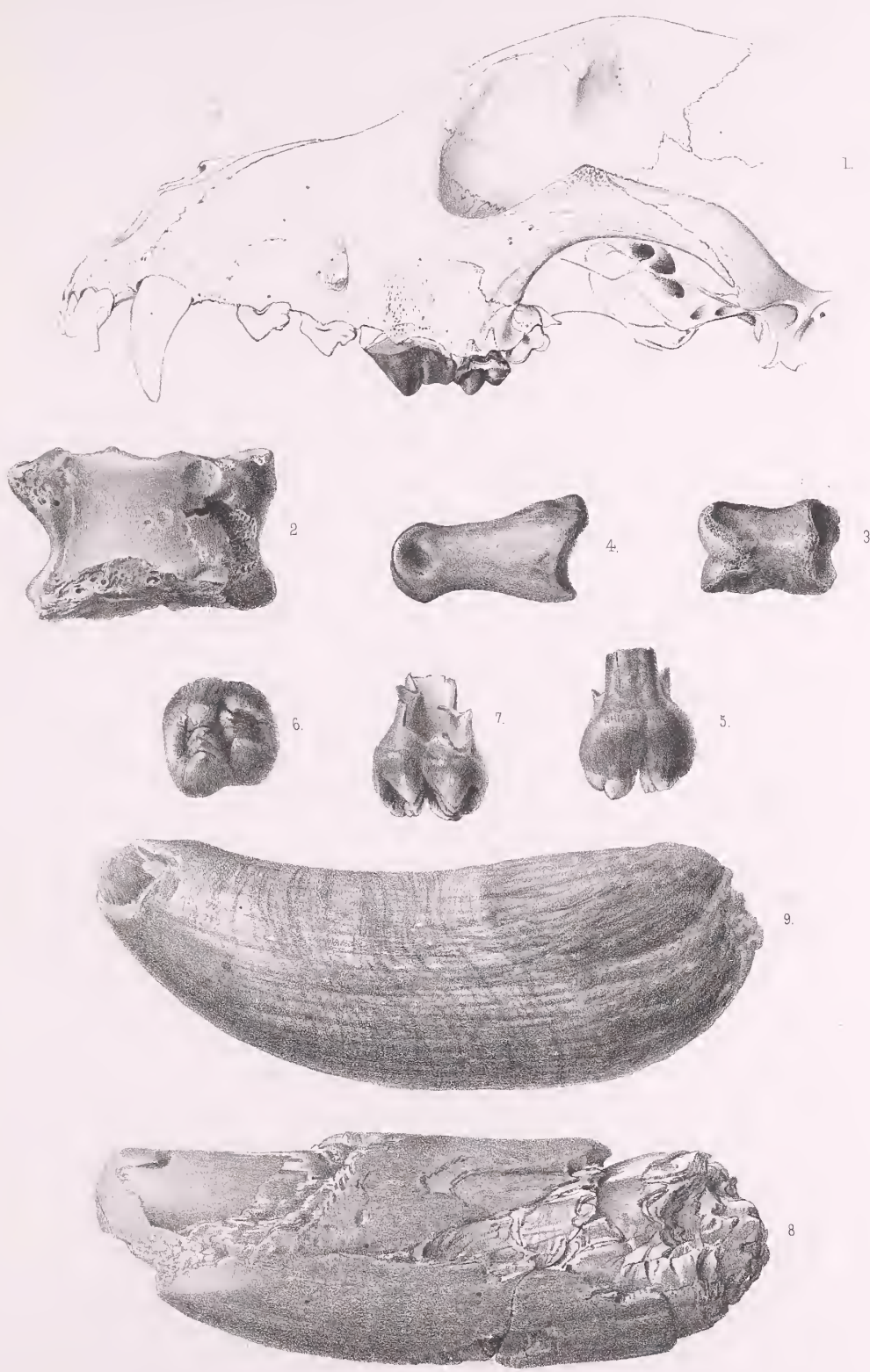


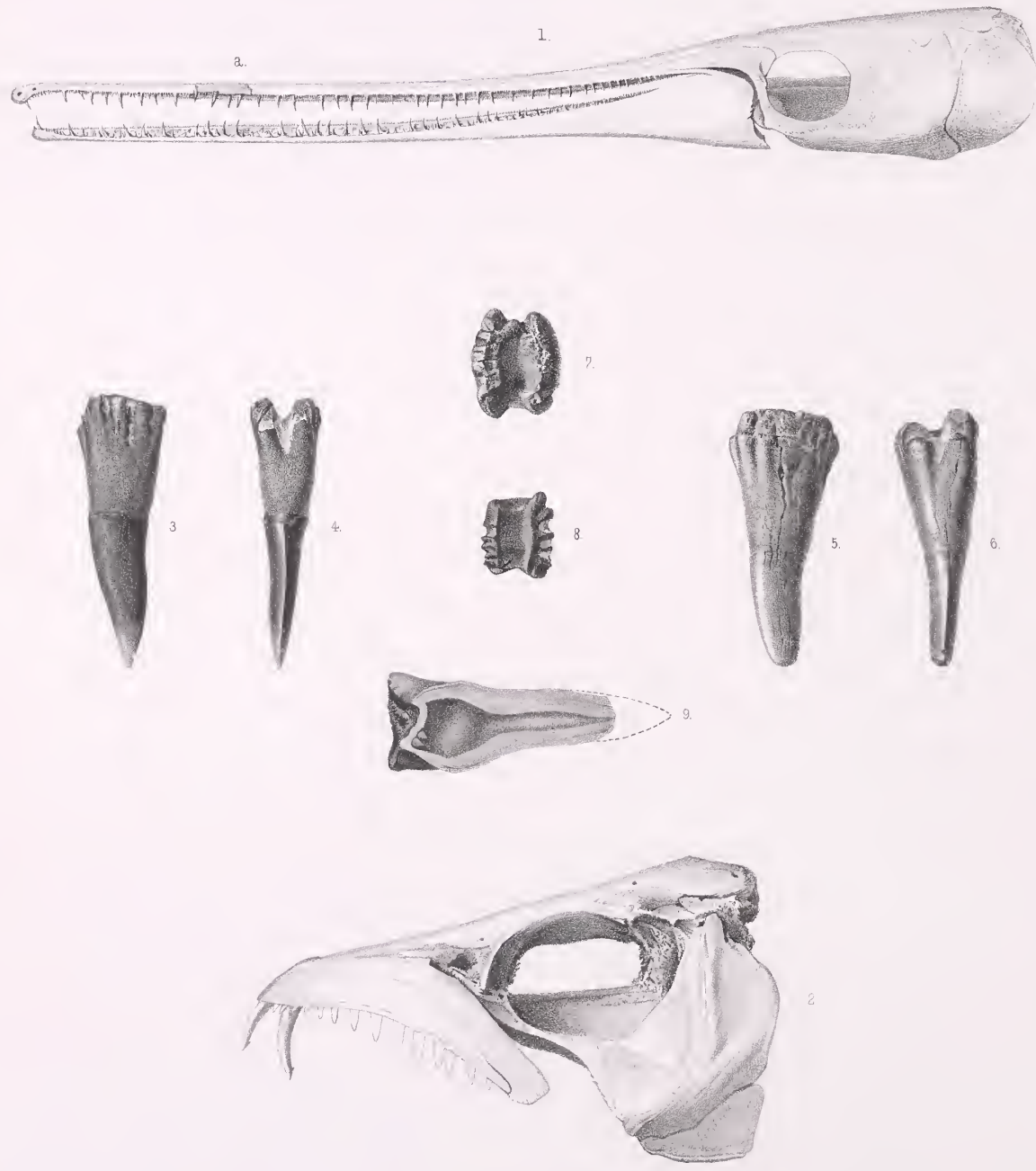


\section{POST-PLEIOCENE FOSSILS.}

PLATE XXV.

Fig. 1. Skull of LEPIDOSTEUS, or the recent Gar fish. The small shaded portion of the jaw, marked

(2) indicates a fossil fragment, apparently of the same species from the Ashley beds. Page 118.

“ 2. Skull of recent TRICHIURUS, or the Ribbon fish. The two anterior, large, barbed teeth, indicating fossil specimens from Simmons'. Page 121.

“ 3. Lateral view of a tooth of ISCHYRHIZA MIRA, Leidy. Page 120.

" 4. Anterior view of the same specimen.

"5. Lateral view of another specimen.

"6. Anterior view of the same.

"7. Bare view of the same.

“ 8. Bare view of Figs. 3, 4 .

“ 9. Interior view of a specimen from the Green Sand of New Jersey, exhibiting the central cavity. 


\section{POST-PLEIOCENE: FOSSILS.}

S O U T H - C A R O L I N A.

\section{PLATE XXVI.}

FIG. 1. Front view of a tooth of CARCHARODON.* Page 119.

“2. Lateral view of the same specimen.

FIGs. 3, 4. Two small teeth resembling those of the existing CARCHARIAS MILBERTI.

“ 5,6. Front and lateral views of a tooth of LAMNA. Page 119.

Fig. 7. Tooth of GALEOCERDO. Page 119.

" 8. Sixteen various small teeth of sharks, undetermined.

*A monograph on the fossil shark teeth of South Carolina will be published in the volume, on the Eocene Fossils of this work. 

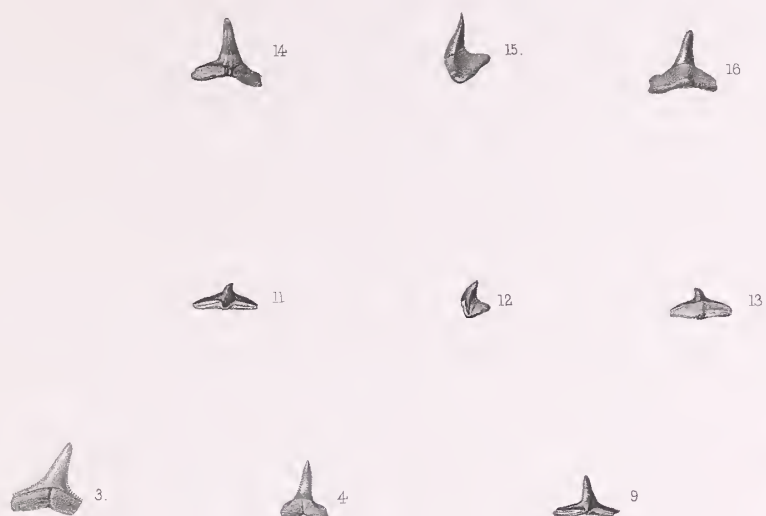

d

$d$

$\infty$
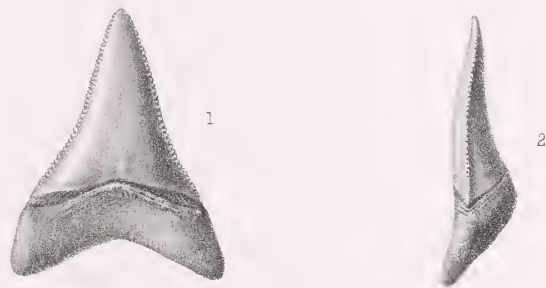

1.

(1)

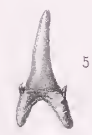

$\int^{6}$ 



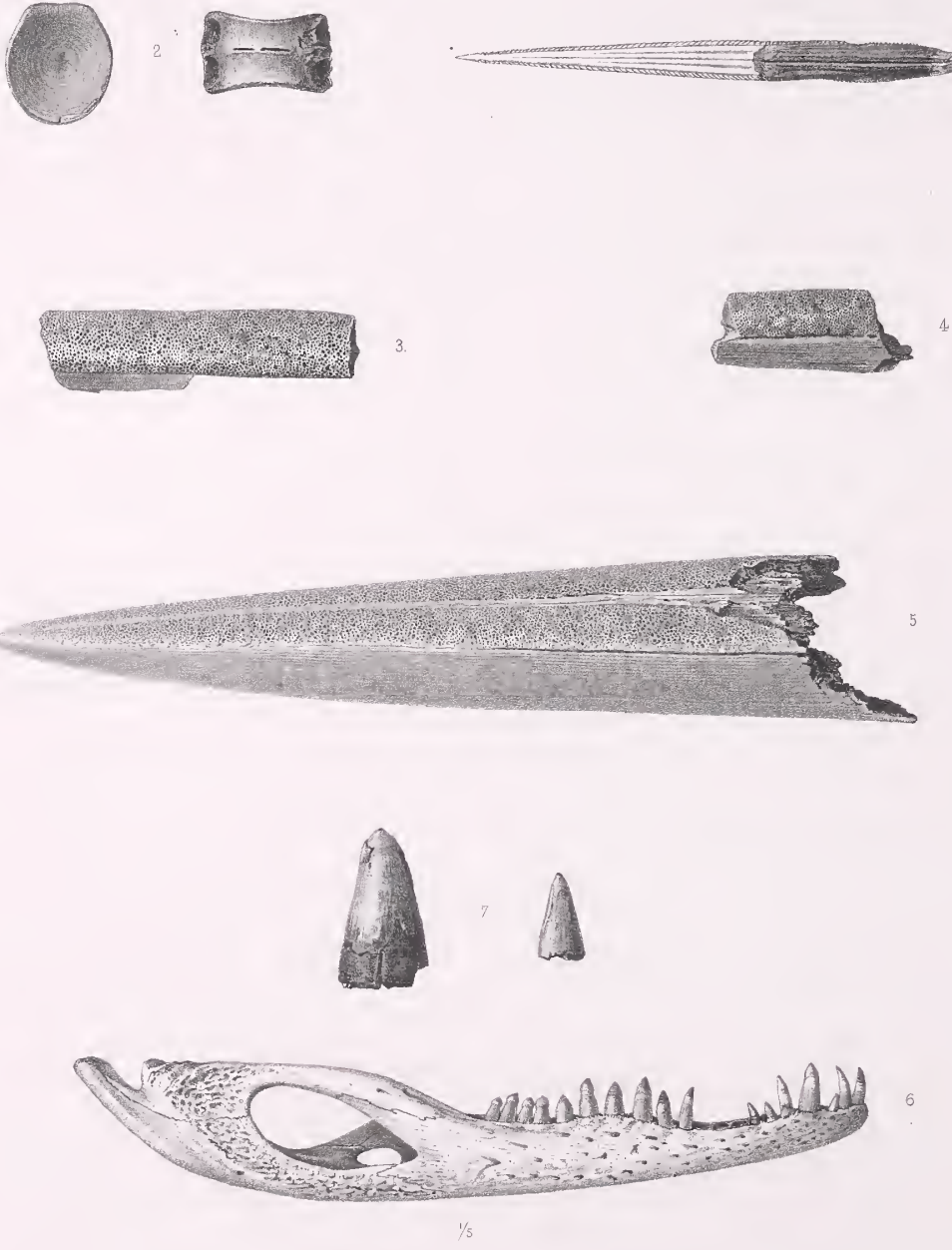


\title{
POST-PLEIOCENE FOSSILS.
}

\author{
S OU TH - C A R OL I NA.
}

\section{PLATE XXVII.}

Fig. 1. Fragment of a spine of a Sting-ray, PASTINACA, restored from a recent specimen. The fossil from Simmons', Yonges Island. Page 119.

2. Vertebrae of the same.

Figs. 3, 4. Fragments of the upper jaw of a Sword fish, XIPHIAS ROBUSTUS. Page 119.

FIG. 5. Extremity of the upper jaw of the same species, from a specimen obtained in the Eocene formation, intended to indicate the position of Figs. 3,4 .

“6. Right side of the lower jaw of the Alligator, from a recent specimen, reduced to one-fifth the diameter of nature.

" 7. Two teeth of the Alligator, from the Ashlcy beds. Page 122. 


\section{POST-PLEIOCENE FOSSILS.}

S O U T H - C A R O L I N A.

\section{PLATE XXVIII.}

FIg. 1. Fragment of a costal plate of a large extinct Turtle, TESTUDO. One half the diameter of nature.

2. Fragment of a costal plate of a smaller species.

Figs. 3, 4. Marginal plates, perhaps of the same species. Page 122 . 

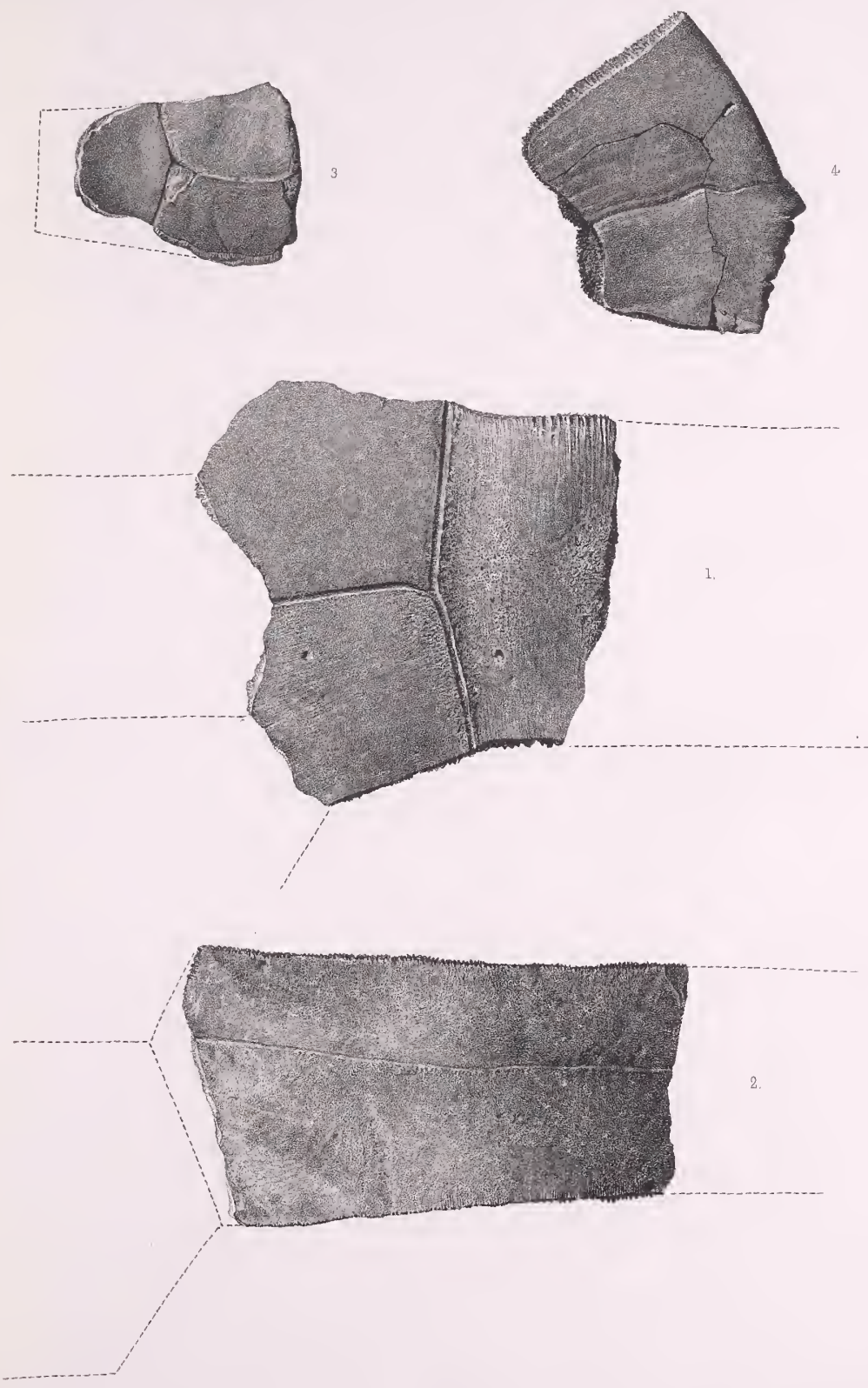

Charleston, So. Ca. 



\section{POST-PLEIOCENE FOSSILS}

O F

\section{S OUT II - CAROLINA.}

B Y

\section{FRANCIS S. HOLMES, A. M.,}

PROFESSOR OF GEOLOGY AND PALEONTOLOGY, AND GURATOR OF TIE MUSEUN OF NATURAL HISTORY COLLEGE OF CHARLESTON, SO. CA ; MEMBER OF THF AMERICAN ASSOCIATION FOR THE ADVANCEMENT OF SCIENCE; CORRESPONDENT OF TIIE ACADEMY OF NATURAL SCILNCES OF

PHILADELPIIA, AND LYCEUM OF NATURAL HISTORY, NEW-YORK.

Nos. $1 \mathrm{AND} 2$.

also in to $\mathrm{V}$.

- pper 1-64.1858

CHARLESTON, S. C.

R USSFL \& J N N E, 251 KING-STREET.

1858.

JAMES \& WILLIAJS, PRINTERS, 16 STATE-STREET. 



\section{POST-PLEIOCENE FOSSILS}

OF

\section{SOUTH - C A R O L I N A.}

B Y

FRA N ('ISS S. HOLMES, A. M.,

PTOAESSOR OF GEOLOGY AND PALEONTOLOGY, AND CURATOR OF THE MUSEUA OF NATURAL HISTORY, COLLEGE UF CIARLESTON, SO. CA.; HEMBER OF THE AMERICAN ASSOCIATION FOR TIIE ADVANCEHENT OF SCIENCE; CORRESPONDENT OF THE ACADEMY OF NATURAL SCIENCES OF PIILADELPHIA, AND LYCEUI OF NATURAL HISTORY, NEW-YORK.

Nos, 6 AND 7

CHARLESTON, S. C.

RUSSELI \& JONES, 251 KING-STPEET.

$$
1859 \text {. }
$$

JAMES \& WLLIAMS, PRINTERS, 16 STATE-STREET. 



\section{POST-PLEIOCENE FOSSILS}

of

\section{SOU T II - C A R O L I A A.}

B Y

FRA NCIS S. HOL MES, A. M.,

PROEESSOR OF GEOLOGY AND PALEONTOLOGY, AND CURATOR OF THE MUSEUM OF NATURAJ.

UTSTORY, COLLEGE UF CHARLESTON, SO. CA.; MEMBER OF TIE AMERICAN ASSOCIATION FOR THE ADVANCEMENI OF SCIENCE ; CORRESPONDENT OF THE ACADEMY OF NATURAL. SCIENCES OF PHILADELPHIA, AND LYCEUH OF NATURAL IISTORY, NEW-YORK.

Nos, 8, 9 AND 10 .

CHARLESTON, S. C.

RUSSLLL \& J0NES, 251 KING-STREET.

1859.

JAMES \& WILLIAMS, PRINTERE, 16 STATE-STREET. 



\section{POST-PLEIOCENE FOSSILS}

$\mathrm{OF}$

\section{SOUTH-CAROLINA.}

BY

\section{FRANCIS S. HOLMES, A.M.,}

PROFESSOR OF GEOLOGY AND PALEONTOLOGY, AND CURATOR OF THE MUSELA OF NATURAL HISTORL. COLLEGE OF CIIARLESTON, SO. CA.

MEMBER OF THE AMERICAN ASSOCIATION FOR THE ADVANCEMENT OF SCIENCE; CORRESPONIENT OF THE ACADEMY OF NATURAL SCIENCES OF PHLADELPHIA, AND

LTCEUM OF NATURAL HISTORY, NEW-YORK.

\section{Nos, 11 AND 12.}

CHARLESTON, S. C.

RUSSELL \& JONES, 251 KING-STREET. 1860 . 



\title{
POST-PLEIOCENE FOSSILS
}

\author{
OF \\ SOUTH-CAROLINA.
}

B Y

FRA NCIS S. HOLMES, A. M.,

PROFESOR OF GEOLOGY AND PALGONTOLOGY, AND CLRATOR OF TUE MLSELM OF MATLRAL MUSTORY COLLEGE OF CHARLESTON, SO. CA.

MSMDER OF THE AMERICAN ASSOCIATIOX FOR THE ADVANCEMENT OF SCHENCE; CORRESPONDENT OE THE ACADENY OF NATURAL SCTENCES OF PHILADELPHL, AND LYCELII OF NATURAL MISTORY, NEW-TORK.

Nos, 13,14 AND 15 .

C H A R L E T T N, S. C.

RUSSELL \& JONES，251 KING-STREET. 1860 . 



Carded 




